UNIVERSIDADE DE SÃO PAULO

FACULDADE DE FILOSOFIA, LETRAS E CIÊNCIAS HUMANAS DEPARTAMENTO DE GEOGRAFIA

PROGRAMA DE PÓS-GRADUAÇÃO EM GEOGRAFIA HUMANA

ROSIETE MARCOS SANTANA

Os caminhos da regularização fundiária no município de Concórdia do Pará/PA 
ROSIETE MARCOS SANTANA

\section{Os caminhos da regularização fundiária no município de Concórdia do Pará/PA}

(versão revisada)

Dissertação apresentada ao departamento de Geografia da Faculdade de Filosofia, Letras e Ciências Humanas da Universidade de São Paulo para obtenção do título de mestre em Geografia Humana

Área de concentração: Geografia Humana

Orientadora: Profa. Dra. Valéria de Marcos 
AUTORIZO A REPRODUÇÃO E DIVULGAÇÃO TOTAL OU PARCIAL DESTE TRABALHO, POR QUALQUER MEIO CONVENCIONAL OU ELETRÔNICO, PARA FINS DE ESTUDO E PESQUISA, DESDE QUE CITADA A FONTE.

\section{Catalogação na Publicação}

Serviço de Documentação

Faculdade de Filosofia, Letras e Ciência Humanas da Universidade de São Paulo

SANTANA, Rosiete Marcos.

Os caminhos da regularização fundiária no município de Concórdia do Pará/PA / Rosiete Marcos Santana: orientadora Valéria de Marcos. São Paulo, 2010.

178 f. : fig.

Dissertação (Mestrado - Programa de Pós-Graduação em Geografia Humana. Área de Concentração: Geografia Humana) - Faculdade de Filosofia, Letras e Ciências Humanas da Universidade de São Paulo.

1. Regularização fundiária. 2. Território. 3. Campesinato. I. Título. 
SANTANA, Rosiete Marcos

Os caminhos da regularização fundiária no município de Concórdia do Pará/PA

Dissertação apresentada ao departamento de Geografia da Faculdade de Filosofia, Letras e Ciências Humanas da Universidade de São Paulo para obtenção do título de Mestre em Geografia Humana

Área de concentração: Geografia Humana

Aprovada em: 09/02/2011

\section{Banca Examinadora}

Prof $^{\mathrm{a}}$. Dr $^{\mathrm{a}} .:$ Valéria de Marcos

Instituição: Universidade de São Paulo

Julgamento: Assinatura:

Prof. Dr.: Ariovaldo Umbelino de Oliveira Instituição: Universidade de São Paulo Julgamento: Assinatura:

Prof $^{\mathrm{a}}$. Dr ${ }^{\mathrm{a}}$.: Renata Medeiros Paoliello Instituição: Universidade Estadual Paulista Julgamento: Assinatura: 


\section{AGRADECIMENTOS}

Aos camponeses e camponesas que me receberam com carinho e atenção em seus lares $e$ compartilharam comigo um pouco de suas vidas.

À Prof'. Dr ${ }^{a}$. Valéria de Marcos, que nos anos de convivência, muito me ensinou, contribuindo para meu crescimento enquanto pesquisadora. Obrigada pela amizade e atenção.

À Prof ${ }^{a}$. Dr ${ }^{a}$. Marta Inêz Medeiros Marques e ao Prof. Ariovaldo Umbelino de Oliveira pelas contribuições na qualificação.

Aos professores com os quais fiz disciplinas pelas idéias divididas e discutidas em sala.

Aos professores e amigos com os quais convivi no Laboratório de Agrária pela atenção e o carinho.

Aos amigos que me acompanharam nesta jornada pela amizade e companhia.

Á minha família pela torcida e estímulo.

Ao Alexandre pela atenção, companheirismo, paciência e amor durante todo o tempo em que estamos juntos.

À Secretaria estadual de Educação pela concessão de bolsa para o mestrado. 


\section{RESUMO}

SANTANA, Rosiete Marcos. Os caminhos da regularização fundiária no município de Concórdia do Pará/PA. 2010. 178f. Dissertação (Mestrado em Geografia Humana) Faculdade de Filosofia, Letras e Ciências Humanas, Universidade de São Paulo, São Paulo, 2010.

O estudo das comunidades Jutaí-Mirim, Campo Verde e Nova Esperança localizadas no município de Concórdia do Pará permite a compreensão acerca dos caminhos da regularização fundiária no Pará. O estudo busca elucidar a diversidade de formas de regularização das terras e, se esta serve de modelo ou não para a diversidade de configuração territorial na região. Busca também compreender como a diversidade de relações entre as comunidades e outros grupos externos a elas acaba por intervir no processo de escolha dos proprietários agrícolas sobre a melhor forma de regularizar suas terras. Para a realização do estudo foram de fundamental importância diversos procedimentos, como a pesquisa de campo, desenvolvida com base na Observação do Participante, na História de Vida, entrevistas abertas/livres e semi-estruturadas, e, diversos registros fotográficos como forma de retratar as práticas sócio-territoriais das famílias. Além da pesquisa de campo foi necessário o levantamento bibliográfico e documental em diversas instituições e entidades. As comunidades Nova Esperança, Campo Verde e Jutaí-Mirim estão localizadas no município de Concórdia do Pará, estado do Pará, e desde fins da década de 1990, as famílias destas comunidades vêm vivenciando intensas discussões sobre a melhor forma de conseguir a regularização de suas posses. O resultado de longos anos de debates foi que, ao invés das três comunidades serem reconhecidas como comunidades remanescentes dos quilombos, que era a proposta inicial, duas delas optaram por escolher outros procedimentos para a regularização. Movimentos sociais, Igreja e entidades tiveram um importante papel nessas escolhas.

Palavras - Chaves: processo de reconhecimento - regularização fundiária - território campesinato - comunidade 


\begin{abstract}
SANTANA, Marcos Rosiete. The paths of land tenure in the city of Concórdia do Pará /

PA. 2010. 173f. Thesis (MA in Human Geography) - Faculty of Philosophy and Humanities, University of São Paulo, São Paulo, 2010.

The study communities Jutaí-Mirim, Campo Verde and Nova Esperança in the municipality of Concórdia do Pará gives an understanding about the ways of land tenure in Para The study aims to elucidate the diversity of forms of regularization of the land and forge it or not also a diversity of territorial configuration in the region. It also seeks to understand how the different relationships between communities and other groups external to them eventually intervene in the process of choice for farmers on how best to regulate their land. To conduct the study were of fundamental importance various procedures, such as field research, developed based on Participant Observation, in the History of Life, open interviews / open and semi-structured, and as a portrayal of the socio-territorial practices of families were performed several photographs. Besides the field survey was necessary to the bibliographic and documentary in various institutions and entities. Communities Nova Esperança, Campo Verde and JutaíMirim is located in the municipality of Concórdia do Pará, Pará State since the late 1990s, the families of these communities have been experiencing intense discussions about how best to achieve settlement of their possessions. The result of many years of discussion was that, instead of the three communities are recognized as remnants of Quilombo communities, which was originally proposed, two of them chose other procedures for the settlement. Social movements, church organizations and played an important role in these choices.
\end{abstract}

Key - words: recognition process - land tenure - territory - peasants - community 


\section{LISTA DE FIGURAS}

Figura 1: Área quilombola identificada por associações quilombolas e localização da área reconhecida como Território Quilombola onde se localiza Campo Verde. .50

Figura 2: Calendário Agrícola. .153 


\section{LISTA DE GRÁFICOS}

Gráfico 1: Número de títulos expedidos no Brasil por ano e por órgão (1995 - 2009)...........55

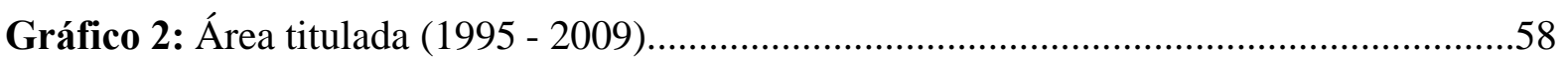

Gráfico 3: Número de titulações no Pará por ano e por órgão $(1995$ - 2009).........................68

Gráfico 4: Área titulada no Pará por ano e por órgão $(1995$ - 2009)....................................68 
LISTA DE MAPA

Mapa 1: Localização da área identificada como pertencente a remanescentes das comunidades dos quilombos e das comunidades em estudo. 104 
LISTA DE FLUXOGRAMA

Fluxograma 1: Fases de produção da farinha de mandioca................................................156 


\section{LISTA DE FOTOS}

Foto 1: Formação da CPT, na comunidade Santo Antônio, Concórdia do Pará. Os participantes são camponeses de diversas comunidades. Em pé temos a irmã Rosa, da CPT/Guajarina. .48

Foto 2: Casas da agrovila construídas pelo INCRA 81

Foto 3: Conjunto de casas de madeira e de alvenaria formado pela casa da mãe e dos filhos casados. Cada filho teve o início da construção de sua casa feito pelo INCRA bem lado da sua de madeira que já existia. As outras casas estão por trás da escola que está à direita.

Foto 4: Placa colocada no arraial da comunidade indicando o seu nome e localização. .88

Foto 5: Placa de identificação da empresa na fazenda comprada por ela da família Fonteles.91

Foto 6: Posse de um dos moradores de Nova Esperança que foi vendido para a Biovale. Observe à esquerda, a cerca da fazenda.

Foto 7: A mesma propriedade da foto anterior, após a venda. Já não existem mais nem a cerca da fazenda, nem a casa dos moradores.

Foto 8: Igreja de Sant'Anna, na Vila Sant'Anna, município de Bujaru/PA, que data do século XVIII. . .98

Foto 9: Arraial do Campo Verde onde vemos, da esquerda para a direita, o salão paroquial, a escola, a casa das mães e a igreja. Por trás da escola e da casa de mães existe uma estrada vicinal que para a esquerda vai para o assentamento Santa Maria e para a direita para a estrada vicinal Transjutaí...... 106

Foto 10: No centro está o senhor Miguel cercado pelo filho e irmãos, na comunidade Campo Verde, Concórdia do Pará.....

Foto 11: Senhor Tomé e sua esposa a senhora Camila, na comunidade Campo Verde, Concórdia do Pará.

Foto 12: Participantes do grupo de mulheres de Campo Verde no IX Congresso do MMTCCB, em Santo Antônio, Concórdia do Pará. 114

Foto 13: Caminhonete que transporta os moradores de Campo Verde e de algumas comunidades pela Transjutaí. Dentro do carro as pessoas esperam as que ainda estão fazendo compras na cidade de Concórdia do Pará para voltarem à suas comunidades.

Foto 14: Barco no rio Bujaru que transporta pessoas e produtos de diversas comunidades de Bujaru e de Concórdia do Pará para Belém.. .118

Foto 15: Culto em homenagem a São Tomé, padroeiro da comunidade, realizado nas véspera da Missa com o padre. 
Foto 16: Momento da festa na sala de aula da escola, no momento do bingo. À direita estão alguns dos brindes doados por famílias da comunidade.

Foto 17: A nova igreja de Campo Verde.

Foto 18: Arraial do Jutaí-Mirim. Da esquerda para a direita, temos as casas da família do senhor Manoel, a igreja de N. S. de Fátima, a barraca da santa e a escola. No primeiro plano observa-se no chão um capim baixo: é parte do campo de futebol. Temos também a estrada vicinal que, pela esquerda segue para a comunidade Ipanema, e pela direita para a estrada vicinal Transjutaí.

Foto 19: Arraial de Nova Esperança. Temos a rodovia PA 140, em seguida a quadra de areia, mais ao fundo, da esquerda para a direita, a igreja em madeira, a que está em construção e o posto médico. Este era o momento em que as jovens estavam aguardando chegar mais gente para iniciarem o jogo de futebol do sábado à tarde.

Foto 20: Senhora Sante no quarto onde atende os clientes, diante de seu altar.....

Foto 21: A senhora Sante cuidando de um corte no dedo do esposo com leite da folha de bananeira. Esse corte foi causado na hora em que ele raspava mandioca. Ao fundo, as várias plantas que ela tem em seu sítio: açaizeiros e mangueiras.

Foto 22: Capina da roça: trabalho sendo realizado por membros de três famílias, na roça que pertence somente a apenas uma delas. Este é um exemplo de ajuda mútua que ocorre na comunidade Campo Verde. 146

Foto 23: A farinha sendo produzida por membros de três famílias, mas pertence somente a uma família. O que ocorre aqui é a ajuda mútua por meio da troca de dias. 146

Foto 24: Em Nova Esperança, a criança na casa de farinha raspando a mandioca, única atividade que ela teria capacidade de realizar, mesmo que brincando. 148

Foto 25: Roça onde está sendo plantada a maniva. O camponês está jogando a terra sobre a maniva que já está na cova. A roça não é dele, é do irmão, mas ele está ajudando. Ao fundo podemos observar a capoeira que precisou ser derrubada e queimada para se fazer esta roça, onde o milho já está crescendo.

Foto 26: O plantio do arroz na comunidade Jutaí-Mirim 152

Foto 27: Jutaí-Mirim: casa de farinha. Da esquerda para a direita é a massadeira, a caixa de peneirar e os fornos

Foto 28: Dentro dos barcos, passageiros com suas redes disputam espaço com os pacotes de farinha e malva. Cada barco chega a carregar 700 pacotes de 30 quilos de farinha. 157 
Foto 29: Porto da Foz do Cravo, local para onde se dirigem camponeses de diversas comunidades com seus pacotes de farinha para serem transportados pelos barcos até Belém....... 158

Foto 30: Área plantada com pimenta consorciada com o cacau, na comunidade Nova Esperança. 159

Foto 31: Em Nova Esperança, enquanto os pais raspam a mandioca, as crianças vão debulhando o açaí para o jantar. 160

Foto 32: A senhora Maria, do Jutaí-Mirim, observa as galinhas enquanto elas comem. Ela está em baixo de uma barraca onde fica o local onde as galinhas põem os ovos, onde guardam a roupa do trabalho e onde ela faz o fogo para cozinhar ou assar alguma comida. 162 Foto 33: No rio Bujaru, o jovem José Maria espera o momento certo para puxar a tarrafa. Ele geralmente vai com a irmã, que neste momento rema a canoa e quando a tarrafa ficava presa no fundo do rio, ela pula para soltar. 163

Foto 34: Sandálias ornamentadas pela senhora Graça, em Nova Esperança 165

Foto 35: Bolsas confeccionadas pela senhora Graça, em Nova Esperança 165 


\section{LISTA DE TABELAS}

Tabela 1 - Títulos expedidos e a Área titulada por órgão (1995 - 2009)................................57

Tabela 2 - Títulos expedidos por órgão (1995 - 2009)..........................................................67

Tabela 3 - Número de posses por estado e módulo fiscal ......................................................84 


\section{LIST A DE SIGLAS}

\begin{tabular}{|c|c|}
\hline $\mathrm{ABA}$ & Associação Brasileira de Antropologia \\
\hline $\mathrm{ACOB}$ & Associação Cultural de Óbidos \\
\hline ADCT & ADCT Ato das Disposições Constitucionais Transitórias \\
\hline ADIN & Ação Direta de Inconstitucionalidade \\
\hline ARQMO & $\begin{array}{l}\text { Associação das Comunidades Remanescentes de Quilombos do Município } \\
\text { de Oriximiná }\end{array}$ \\
\hline ARQUINEC & $\begin{array}{l}\text { ARQUINEQ Associação de Remanescentes de Quilombos Nova Esperança } \\
\text { de Concórdia do Pará }\end{array}$ \\
\hline ASPRUNE & Associação de Produtores Rurais Nova Esperança \\
\hline ATAJI & Associação dos Trabalhadores do Assentamento Jutaí e Ipanema \\
\hline $\mathrm{CCN}$ & Centro de Cultura Negra do Maranhão \\
\hline CDRU & Concessão de Direito Real de Uso \\
\hline CEB & Comunidade Eclesial de Base \\
\hline CEDENPA & Centro de Estudos e Defesa do Negro do Pará \\
\hline $\mathrm{CNBB}$ & Conferência Nacional dos Bispos do Brasil \\
\hline CONAB & Companhia Nacional de Abastecimento \\
\hline CONEPPIR & Conselho Estadual de Políticas de Promoção da Igualdade Racial \\
\hline CPI-SP & Comissão Pró-Índio de São Paulo \\
\hline CPT & CPT Comissão Pastoral da Terra \\
\hline DEM & Democratas \\
\hline EJA & Educação de Jovens e Adultos \\
\hline EMATER & Empresa de Assistência Técnica e Extensão Rural \\
\hline FCP & Fundação Cultural Palmares \\
\hline FETAGRI & Federação dos Trabalhadores na Agricultura no Estado do Pará \\
\hline FNB & Frente Negra Brasileira \\
\hline INCRA & Instituto de Colonização e Reforma Agrária \\
\hline ITERPA & Instituto de Terras do Pará \\
\hline MALUNGU & Associações das Comunidades Remanescentes de Quilombos do Pará . \\
\hline MDA & Ministério do Desenvolvimento Agrário \\
\hline МMTCCB & Movimento das Mulheres Transformadoras do Campo e da Cidade de Bujaru \\
\hline MNU & Movimento Negro Unificado \\
\hline MNUCDR & Movimento Negro Unificado contra a Discriminação Racial \\
\hline MPA & Movimento de Pequenos Agricultores \\
\hline MST & Movimento dos Trabalhadores Sem Terra \\
\hline NAEA & Núcleo de Altos Estudos Amazônicos \\
\hline OIT & Organização Internacional do Trabalho \\
\hline PEAEX & Projeto Estadual de Assentamento Agroextrativista \\
\hline PEAS & Projeto Estadual de Assentamento Sustentável \\
\hline PEPPIR & Plano Estadual de Políticas de Promoção da Igualdade Racial \\
\hline PFL & Partido da Frente Liberal \\
\hline PMDB & Partido do Movimento Democrático Brasileiro \\
\hline
\end{tabular}




$\begin{array}{ll}\text { PPQ } & \text { Programa Pará Quilombola } \\ \text { PROA } & \text { Pró-Assentamento Estadual } \\ \text { RTID } & \text { Relatório Técnico de Identificação e Delimitação } \\ \text { RTID } & \text { Relatório Técnico de Identificação e Delimitação } \\ \text { SECTAM } & \text { Secretaria de Estado de Ciência, Tecnologia e Meio Ambiente } \\ \text { SEJU } & \text { Secretaria Executiva de Justiça } \\ \text { SEJUDH } & \text { Secretaria de Estado de Justiça e Direitos Humanos } \\ \text { SISTERLEG } & \text { Sistema Terra Legal } \\ \text { SPU } & \text { Secretaria de Patrimônio da União } \\ \text { STR } & \text { STR Sindicato dos Trabalhadores Rurais } \\ \text { CUT } & \text { Central Única dos Trabalhadores } \\ \text { TEQ } & \text { Território Estadual Quilombola } \\ \text { UFPA } & \text { Universidade Federal do Pará }\end{array}$




\section{SUMÁRIO}

INTRODUÇÃO 19

\section{A EMERGÊNCIA DOS QUILOMBOS E A REVISÃO DE CONCEITOS E NORMAS}

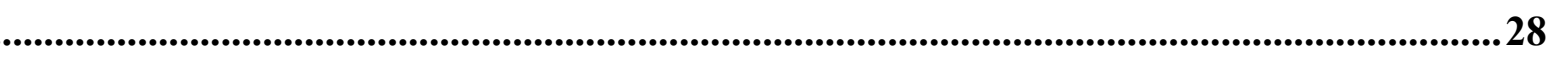

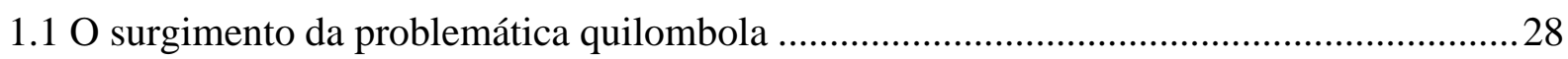

1.2 A regularização entre a interpretação das normas e conceitos ......................................... 30

2. A EMERGÊNCIA DO TERRITÓRIO QUILOMBOLA..............................................41

2.1 Como tudo começou: a descoberta ..............................................................................41

2.2 A mobilização em prol do território quilombola .......................................................... 44

3. AS DIFERENTES PROPOSTAS DE REGULARIZAÇÃo FUNDIÁRIA: E O TERRITÓRIO QUILOMBOLA?....................................................................................54

3.1 O Território Quilombola e Campo Verde ........................................................................54

3.1.1 A regularização dos territórios quilombolas no Brasil .......................................................54

3.1.2 A regularização dos territórios quilombolas no Pará .....................................................59

3.1.2.1 Quadro da política de regularização no Paráa................................................................. 66

3.1.3 Campo Verde, um território quilombola........................................................................ 71

3.2 Jutaí-Mirim: Território Quilombola ou Projeto de Assentamento?.....................................75

3.2.1 Território em disputa ................................................................................................... 75

3.2.2 O assentamento Jutai e Ipanema ................................................................................... 79

3.3 O Programa Terra Legal Amazônia e Nova Esperança....................................................... 83

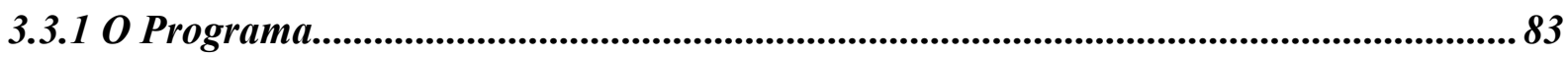

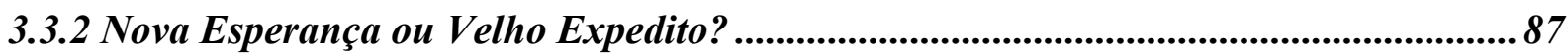

4. OS TERRITÓRIOS EM ESTUDO.................................................................................96

$4.1 \mathrm{O}$ processo de formação territorial: do rio à estrada..........................................................96

4.2 Três comunidades e um modo de vida: o camponês ........................................................... 105

4.2.1 Campo Verde .................................................................................................................... 105

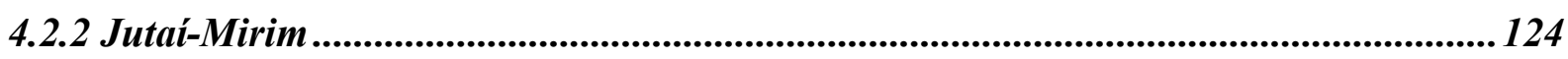

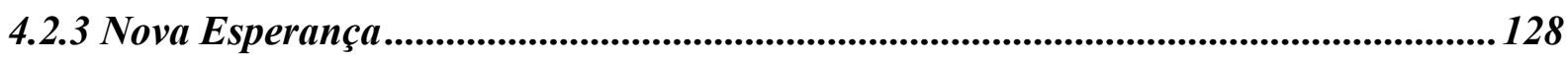

4.2.4 A religiosidade camponesa ............................................................................................... 136

4.2.5 As Comunidades Eclesiais de Base....................................................................... 138

4.2.6 A organização do trabalho e da produção nas três comunidades ................................. 144

CONSIDERAÇÕES FINAIS...............................................................................................166

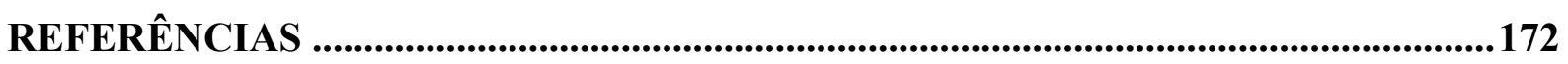




\section{INTRODUÇÃO}

Sempre se soube que o campesinato e o proletariado rural brasileiro são compostos por uma grande parcela de população negra, mas isso nunca, até meados da década passada, conferiu particularidade a essa população. Na década de 1980, os rumos da discussão sobre a reforma agrária da Nova República começaram a apontar para uma particularidade: a da posse da terra desta população no norte do país, em especial Maranhão e Pará. Chamou-se a atenção para a existência de inúmeras situações em que o campesinato se organizava de forma distinta da que sempre orientou os assentamentos de reforma agrária, baseados em um parcelamento individualizado da terra. Essa forma distinta está fundada basicamente na existência de terras de uso comum, que eram parcelas indivisas transmitidas de geração em geração ao conjunto dos moradores de uma determinada comunidade rural. Todavia, essa particularidade não conseguiu imprimir mudanças na concepção dominante sobre o trato da questão agrária (ARRUTI, 2003).

No momento decisivo de definição do novo texto constitucional de 1988, o projeto de reforma agrária naufragou, perdendo-se assim a oportunidade da realização de uma reforma agrária efetiva. No entanto, neste mesmo momento, foi conquistada a possibilidade de reconhecimento das terras dos denominados pela Constituição de "remanescentes das comunidades dos quilombos", o que é proposto como uma medida de reparação histórica e cultural dirigidas à população negra (ARRUTI, 2003). O artigo que encontramos no texto constitucional é o $\mathrm{n}^{\circ}$ 68, do Ato das Disposições Constitucionais Transitórias (ADCT), que possui o seguinte enunciado: "Aos remanescentes das comunidades dos quilombos que

estejam ocupando suas terras é reconhecida a propriedade definitiva, devendo o Estado emitir-lhes os títulos respectiv os" (BRASIL, 1988)

O estudo das comunidades Jutaí-Mirim, Campo Verde e Nova Esperança, no município de Concórdia do Pará, objetiva identificar e compreender as diversas formas de regularização fundiária que ocorrem no Pará, verificar se estas formas imprimem uma diversidade de configuração territorial no estado e como a diversidade de relações entre comunidade e outros grupos a elas externos acabam por intervir no processo de escolha dos camponeses sobre a melhor forma de regularizar suas terras.

Minha identificação com o debate em tomo do campo na Amazôniadecorreu da oportunidade de estudar e pesquisar questões referentes ao campo paraense, como a luta pela terra, o sindicalismo e os movimentos sociais, durante minha graduação na Universidade Federal do Pará, estudos esses 
realizados sob a orientação do Prof. Jean Hebette, importante estudioso da questão agrária na Amazonia.

O contato com as comunidades se inicia com viagens realizadas a uma das comunidades de Concórdia que está em processo de reconhecimento como quilombola: a comunidadeCravo. Ao saber deste fato, busquei entender melhor como istoocorria. O temada pesquisa surgiu nesta busca, onde foi posśvel perceber que antes mesmo do processo de reconhecimento, existe um processo de identificação que nem sempre é fácil, que nem sempre é aceito por todas as famílias e que era uma questão que não estava restrita aos moradores das comunidades, e sim envolvia igreja, sindicato, movimentos sociais e instituições públicas.

Para realizar o estudo foi de fundamental importância a pesquisa de campo. De acordo com Oliveira \& Oliveira (1981) neste tipo de pesquis a o pesquisador procura observar a vida social em movimento, procurando captar a rede de relações sociais que atravessa a comunidade, os problemas que a desafiam e a percepção que a população tem de sua própria situação e de suas possibilidades de mudança.

O primeiro trabalho de campo foi realizado em fevereiro de 2008 e teve um caráter exploratório. Foi neste campo que as comunidades foram selecionadas para a pesquisa a partir de uma visita às várias comunidades que estavam inseridas na área identificada como território quilombola pela Associação das Comunidades de Remanescentes de Quilombos Nova Esperança de Concórdia do Pará (ARQUINEC). Essa visita teve como objetivo conhecer um pouco mais sobre como o processo de identificação estava sendo visto por elas. Nas visitas, foram entrevistadas lideranças de treze comunidades, sendo uma no município de Bujaru, limite com Concórdia, e as demais em Concórdia. Nestas conversas buscou-se saber algumas informações como: origem, o número de famílias, a existência de áreas de uso comum, as formas de organização das comunidades e se já existia processo de reconhecimento como quilombola em curso. Foram entrevistados também o presidente da associação dos quilombolas de Bujaru e a presidente da associação dos quilombolas de Concórdia do Pará sobre o início dos debates sobre remanescentes de quilombos nestes municípios.

Nesta longa caminhada, foi utilizado como referência um mapa elaborado pelo projeto Nova Cartografia Social sobre a área identificada. Além das comunidades registradas no mapa, havia muitas outras dentro da área, mas as visitas foram realizadas somente nas mapeadas, pela compreensão de que as que estavam ligadas às associações estariam mobilizadas. Todavia, foi percebido que se tratava de um equívoco, pois as outras comunidades também estavam mobilizadas, apenas não o estavam em torno das associações 
quilombolas, mas sim em torno de outras associações e Sindicato dos Trabalhadores Rurais (STR).

Em relação às comunidades que estavam associadas à Associação Remanescente de Quilombos Nova Esperança de Concórdia do Pará (ARQUINEC), foi observado que, em algumas delas, somente um pequeno grupo de famílias queria o reconhecimento como remanescentes das comunidades dos quilombos. As demais famílias desejavam a constituição de um projeto de assentamento ou outra forma de regularização fundiária.

$\mathrm{Na}$ escolha das comunidades aqui estudadas (Campo Verde, Jutaí-Mirim e Nova Esperança), levou-se em consideração as propostas de regularização fundiária que foram apresentadas a estes camponeses pelo INCRA e pela CPT e o estágio em que se encontrava o processo de regularização das terras.

Os demais campos realizados foram nas comunidades selecionadas para este estudo e ocorreram no segundo semestre de 2008, janeiro de 2009, no primeiro semestre de 2010, sendo que em janeiro foi em companhia da Professora Valéria de Marcos. No restante do semestre, o campo se restringiu aos dias em que ocorriam reuniões para discutir assuntos referentes à regularização.

Minha chegada a cada um das comunidades foi inesperada, pois não tive como entrar em contato antecipadamente com as lideranças. Como eu já sabia que estas comunidades rurais normalmente se organizam por meio de uma coordenação/diretoria, procurei pelo presidente/coordenador da comunidade. Em Campo Verde, encontrei como presidente, o senhor Miguel Modesto; em Jutaí-Mirim encontrei o jovem Nery, presidente da comissão do assentamento, e em Nova Esperança, encontrei Jaciara, que não era a presidente, mas era uma liderança reconhecida na comunidade, por sua atuação no STR. A partir destas pessoas, que inclusive também me acolheram em suas casas durante o tempo em que fiquei nas comunidades, pude chegar às demais lideranças.

Para a realização da pesquisa, fiz uma observação participante, onde acompanhei o dia-a-dia das famílias, contribuindo com diversas tarefas e ao mesmo tempo tentando apreender o universo de trabalho, lazer, religião e política vivenciado pelas famílias. Participei também dos encontros e reuniões realizados dentro e fora das comunidades.

Para conhecer e compreender como ocorreu o processo de formação territorial das comunidades, utilizei da técnica denominada História de Vida, gênero da História Oral (FREITAS, 2006). Por meio desta técnica, busquei uma "reconstituição" do passado, efetuada pelas próprias pessoas entrevistadas, sobre elas mesmas: como chegaram nas terras, de onde vieram, como viviam depois que chegaram nas terras, suas relações de vizinhança, 
os conflitos pela terra, o início das mobilizações para garantir a permanência nas terras. Isto foi feito com lideranças e com os mais antigos das comunidades.

Foram realizadas também entrevistas abertas/livres com as lideranças, moradores mais antigos e com algumas famílias, com as quais tive a oportunidade de conversar, sobre diversos aspectos da vida camponesa, como a religião, o lazer, a produção, a história da comunidade, a vida em comunidade e a questão da regularização das terras. Estas entrevistas eram realizadas na própria posse familiar, na casa, na roça ou na casa de farinha. Também foram realizadas entrevistas com representantes da Comissão Pastoral da Terra (CPT/Guajarina), do Instituto de Colonização e Reforma Agrária (INCRA), do STR, da Coordenação das Associações das Comunidades Remanescentes de Quilombos do Pará (MALUNGU). De acordo com Oliveira \& Oliveira (1981), com esta técnica pode-se estimular a livre expressão da pessoa com quem se conversa, ampliar o campo do discurso, que passa a incluir não só fatos e opiniões bem delimitadas, mas também devaneios, projetos impress ões, reticências, etc, mas sempre com um fio condutor. Também foram realizadas entrevistas semi-estruturadas com roteiro de perguntas pré-fixadas com uso de gravador.

Além das entrevistas, foi necessário o levantamento bibliográfico e documental nas instituições e entidades e, como forma de retratar o cotidiano de trabalho e práticas sócioterritoriais das famílias, foram realizados diversos registros fotográficos. Além destes procedimentos para a compreensão da realidade estudada, utilizei como categoria de análise o território.

O território resulta da ação de um ator que ao se apropriar de um espaço, o territorializa. Portanto, ele é uma produção a partir do espaço. Essa produção se inscreve num campo de poder por envolver diversas relações (RAFFESTIN, 1993). Ele deve ser apreendido

[...] como síntese contraditória, como totalidade concreta do processo/modo de produção/distribuição/circulação/ consumo e suas articulações e mediações supraestruturais (políticas, ideológicas, simbólicas etc.) em que o Estado desempenha a função de regulação. O território é assim produto concreto da luta de classes travada pela sociedade no processo de produção de sua existência. Sociedade capitalista que está assentada em três classes sociais fundamentais: proletariado, burguesia e proprietários de terra (OLIVEIRA, 2005, p. 74, grifo do autor).

Nesta perspectiva de se pensar o território, o campesinato é visto como uma classe social que é constantemente desarticulada, mas também recriada com o desenvolvimento do capitalismo no campo.

Para se pensar o quilombo como ele é hoje, como defende Almeida (2002), houve a necessidade de se repensar o significado desta palavra, pois isso era de fundamental 
importância para atender à diversidade de situações em que se encontram hoje os camponeses identificados como remanescentes das comunidades dos quilombos.

A palavra quilombo vem sendo sistematicamente usada desde o período colonial (LEITE, 2000). Junto com a palavra mocambo, quilombo, para a maioria das línguas bantu da África Central e Centro Ocidental, significa acampamento (GOMES, 2006), mas em Angola é entendido como uma divisão administrativa (LOPES, SIQUEIRA e NASCIMENTO, 1987).

O Conselho Ultramarino Português de 1740 definiu quilombo como "toda habitação de negros fugidos, que passem de cinco, em parte despovoada, ainda que não tenham ranchos levantados e nem se achem pilões neles" (ALMEIDA, 2002, p.47). Indica, também, uma reação guerreira a uma situação opressiva. Este conceito do Conselho constitui-se basicamente de cinco elementos: 1) a fuga; 2) uma quantidade mínima de fugidos, que variava com o tempo; 3) o isolamento geográfico, em locais de difícil acesso e mais próximos de uma "natureza selvagem" que da chamada civilização; 4) moradia habitual, referida no termo "rancho", e 5) autoconsumo e capacidade de reprodução, simbolizados na imagem do pilão de arroz (ALMEIDA, 2002).

Cada um desses elementos esteve presente nos conceitos sobre quilombos elaborados ao longo de décadas, no imaginário dos operadores do direito e no senso comum (ALMEIDA, 2002). Um exemplo disto é que foi o modelo do quilombo de Palmares que orientou muitos estudos de comunidade, nas décadas de 1930 e 1940, nas ciências sociais no Brasil. Nestes estudos, aparecem as primeiras evidências sobre a existência de bairros negros situados nas áreas urbanas e periféricas e também um campesinato negro, identificado como comunidades negras rurais. Eles introduziram as primeiras formulações que fundamentaram uma visão de grupo como unidade fechada em si mesma, coesa, como uma cultura isolada, com uma suposta harmonia e, portanto ausência de conflito. Isto contribuiu para uma visão idealizada da vida coletiva destas populações, consideradas não mais "primitivas", mas "tradicionais", além de serem congeladas numa visão estática de tradição e da história (LEITE, 2000).

Somente na década de 1980, com a virada teórica dos estudos sobre etnicidade, inaugurada com a crítica feita por Fredrik Barth ao conceito estático de cultura, é que alguns modelos teóricos, até então utilizados, foram considerados ultrapassados, requerendo-se dos antropólogos um novo reposicionamento frente a eles (LEITE, 2000). Na medida em que se intensificaram os contatos com as comunidades remanescentes de quilombos, estudos inovadores ampliaram o conhecimento sobre quilombos e cada um dos elementos citados acima, que compôs por tanto tempo o conceito de quilombo, foi sendo refutado (BARBOSA; GRANDO, 2006). 
De acordo com Schmitt, Turatti e Carvalho (2002) os grupos que hoje no Brasil são considerados "remanescentes" dos quilombos se constituíram a partir de uma grande diversidade de processos, que incluem fugas com ocupação de terras livres e geralmente isolados. Também temos os casos de heranças, doações, pagamento de hipoteca, recebimento de terras como pagamento de serviços prestados ao Estado, a simples permanência nas terras que ocupavam e cultivavam no interior das grandes propriedades, bem como a compra de terras, tanto durante a vigência do sistema escravocrata quanto após a sua extinção.

Historiadores demonstram que muitos quilombos mantinham relações econômicas externas, e tal relacionamento fazia parte da estratégia para garantir a autonomia. Descobriuse, ainda, que existiam quilombos a apenas alguns metros da casa grande (BARBOSA; GRANDO, 2006). Quando havia fuga, esta se desdobrava em um elemento estratégico que era a roça e diversas benfeitorias construídas pelos quilombolas. Sendo assim, é importante também destacar a unidade familiar "que suporta um sistema produtivo específico que vai conduzir ao acamponesamento" (ALMEIDA, 2002, p. 51) com o processo de desagregação das fazendas e a diminuição do poder de coerção dos grandes proprietários. Este sistema produtivo era mais autônomo, livre, com base no trabalho familiar e em formas de cooperação simples entre as famílias (ALMEIDA, 2002).

A compreensão deste sistema está vinculada a ressemantização do conceito de quilombo hoje. Deve-se trabalhar com o conceito de quilombo considerando o que o quilombo é no presente e como foi sendo construída historicamente a sua autonomia a partir da desagregação das grandes plantações. Além deste aspecto objetivo, deve-se levar em consideração a representação dos sujeitos envolvidos. Aqui teríamos um corte nos instrumentos conceituais necessários para pensar o que é o quilombo hoje (ALMEIDA, 2002).

Com o artigo 68 da Constituição Brasileira, a Associação Brasileira de Antropologia (ABA) foi convocada pelo Ministério Público para dar o seu parecer em relação às situações já conhecidas e enfocadas nas pesquisas sobre comunidades negras rurais. Em outubro de 1994, a partir do Grupo de Trabalho sobre Comunidades Negras Rurais, elaborou-se um documento que procurou desfazer os equívocos referentes à suposta condição remanescente. Tratava-se de desfazer a idéia de isolamento e de população homogênea ou como decorrente de processos insurrecionais (LEITE, 2000). Desta forma, a definição da ABA é a de que os remanescentes dos quilombos são grupos étnicos com um tipo organizacional que confere pertencimento por meio de normas e meios que são empregados para indicar filiação ou exclusão (BARBOSA; GRANDO, 2006). 
$\mathrm{Na}$ edição do decreto $\mathrm{n}^{\circ} 4.887$, de 2003, que regulamenta o artigo 68, os remanescentes são considerados "grupos étnico-raciais, segundo critérios de auto-atribuição, com trajetória histórica própria, dotados de relações territoriais específicas, com presunção de ancestralidade negra relacionada com a resistência à opressão histórica sofrida" (BRASIL, 2003).

De acordo com Barbosa e Grando (2006), a análise dos conceitos apresentados acima permite afirmar que se alteraram os elementos que conformavam a definição de quilombo, e os cinco elementos iniciais são trocados por outros que vão compor os conceitos/noções atuais de identidade étnica, territorialidade e autonomia. Com a revisão dos conceitos instaurou-se uma relativização e a adequação dos critérios para se conceituar quilombo, de modo que a maioria dos grupos que hoje reivindica a demarcação e titulação de suas terras possa ser contemplada (SCHMITT, TURATTI e CARVALHO, 2002).

De acordo com Acevedo Marin e Castro (1998), o processo de ressemantização da categoria histórica quilombo, contribui à afirmação étnica e mobilização política das comunidades negras rurais. Estas comunidades constituem um segmento diferenciado pela proposta de demarcação de terras de antiga ocupação: defendem o regime de usufruto comum da terra.

A conceituação de quilombo do documento da ABA ampliou a visão sobre a existência destas comunidades negras rurais atualmente, e conferiu-lhes uma maior pertinência em relação aos pleitos já formulados (LEITE, 2000). Para o reconhecimento das comunidades como quilombolas, ocorre um processo de identificação. No presente trabalho, entende-se este processo como

[...] o movimento de passagem do desconhecimento à constatação por parte dos sujeitos sociais atingidos por um tipo de situação de desrespeito com caráter coletivo, instituindo, assim, tal coletividade como fonte de pertencimento identitário e como sujeito de direitos, moralmente motivado para a mobilização contra tal desrespeito (ARRUTI, 2006, p. 45).

É com o processo de identificação que se inicia um outro processo, o de reconhecimento, aqui entendido como o

[...] movimento de passagem do desconhecido à constatação pública de uma situação de desrespeito que atinge determinada coletividade, do que decorre a admissão de tal coletividade como sujeito (político e de direito) na esfera pública e de tal desrespeito como algo que deve ser sanado ou reparado. (ARRUTI, 2006, p. 45).

Estes processos, o de identificação e o de reconhecimento, são fundamentais para a regularização fundiária das terras de inúmeros camponeses quilombolas. A regularização, de 
acordo com Oliveira (2006), refere-se ao reconhecimento do direito das famílias já existentes nas áreas objeto da ação.

Na referência a Campo Verde, Jutaí-Mirim e Nova Esperança, uso o termo comunidade, entendendo que elas, de acordo com Almeida (2006), compreendem relações sociais como vizinhança, situação comum de interesses, identidade e formas de ação comum que podem ser lidas como relações comunitárias étnicas. Almeida afirma que podem ser lidas como relações comunitárias étnicas porque se tratava de um estudo que realizou em comunidades negras rurais. Para o estudo aqui realizado, sua compreensão da comunidade é aceitável, pois as comunidades estudadas também compreendem as características que ele destaca, mas não são necessariamente entendidas aqui como relações comunitárias étnicas. Isto porque outras dimensões da vida em comunidade do camponês, como a econômica e a política, precisam ser levadas em consideração quando se busca a compreensão das relações desenvolvidas pelo camponês que contribuem para o processo de escolha da forma de regularizar suas terras.

O texto aqui apresentado busca, no seu primeiro capítulo, compreender como emerge o debate em torno das terras ocupadas pelos descendentes de escravos, denominados pelo movimento negro como quilombolas. Também busca-se mostrar a necessidade de se realizar uma revisão de conceitos e normas a respeito do que seria o quilombo para que inúmeras comunidades tivessem direito ao reconhecimento da propriedade das terras que ocupavam há muitos anos. Além disso, são apresentadas as legislações que estão relacionadas com a regularização das terras e todo o processo político, o jogo de forças que cercaram a criação de decretos e instruções normativas que, a cada ano que passa, dificultam cada vez mais o acesso ao direito de titulação das terras.

No segundo capítulo, analisa-se a maneira como a discussão em torno do reconhecimento das comunidades como remanescentes dos quilombos surge no município de Concórdia e o papel da CPT e da ARQUINEC neste processo. Também busca-se mostrar que o mesmo jogo de forças em torno do reconhecimento em uma escala nacional se repete na escala local e envolve uma diversidade de interesses que fazem com que as terras, que antes poderiam ser regularizadas como território quilombola, passem a ser tituladas por meio da criação de projetos de assentamento e pelo Programa Terra Legal Amazônia.

No terceiro capítulo, apresento as formas de regularização das terras nas três comunidades, como e porque ocorre, quais os sujeitos envolvidos neste processo.

Quem são estas famílias que buscam a regularização de suas terras? Como vivem? No último capítulo, apresento as comunidades pesquisadas: o processo de formação territorial de 
cada uma, as diversas formas como as famílias se mobilizam em torno de questões que envolvem a política, a religião, o trabalho, a produção, o lazer. Enfim, mostra-se o modo de vida camponês presente em cada uma. 


\section{A EMERGÊNCIA DOS QUILOMBOS E A REVISÃO DE CONCEITOS E NORMAS}

\subsection{O surgimento da problemática quilombola}

Desde os anos 1930, muitos militantes do movimento negro discutem sobre a necessidade de reparação e da abolição ser vista como "um processo inacabado", além da existência de uma dívida. É no debate em torno destas idéias que o termo quilombo reaparece com a Frente Negra Brasileira (FNB), nos anos 1930 e 1940 (LEITE, 2000). A FNB, criada em São Paulo em 1931, partia de uma perspectiva integracionista e ainda não trabalhava por uma identidade específica, seja social, cultural ou étnica (MELO, 2007). Na década de 1940, a questão avançou através do Teatro Experimental do Negro, fundado em 1944 no Rio de Janeiro, por Abdias do Nascimento. Este, ao contrário da FNB, aliou à atuação política a questão da afirmação cultural, buscando referências na herança africana (MELO, 2007).

A discussão sobre os quilombos contemporâneos foi trazida à tona pelo movimento negro, principalmente nos anos 70, como parte do contexto da luta contra o preconceito racial, sendo os quilombos enfatizados como ícones da resistência negra. Abdias do Nascimento afirma que quilombo significava reunião fraterna e livre, solidariedade, convivência e comunhão espiritual, sendo a manifestação no Brasil do comunitarismo da tradição africana, no qual todos os bens são de propriedade e uso coletivos. O princípio ético do quilombismo seria assegurar a condição humana do povo afro-brasileiro (MELO, 2007).

É neste contexto que, em 1971, o Grupo Palmares, de Porto Alegre/RS, realizou, em 20 de novembro, um ato em homenagem à República dos Palmares, buscando contrapô-la a data de 13 de maio, estabelecida como ícone para a população negra. Com esta mobilização criou a possibilidade da instituição do dia 20 de novembro como Dia Nacional da Consciência Negra. Em 1978, foi fundado o Movimento Negro Unificado contra a Discriminação Racial (MNUCDR), posteriormente conhecido como Movimento Negro Unificado (MNU) e, em 1979, foi fundado o Centro de Cultura Negra do Maranhão (CCN/MA), que tinha um importante papel na mobilização política das comunidades negras rurais. Em 1983, iniciou-se o trabalho do Centro de Cultura Negra do Maranhão (CCN/MA) com as comunidades negras rurais do Maranhão, por meio do Projeto “Comunidades Negras no Meio Rural Maranhense”, coordenado por uma pesquisadora e ex-presidente do CCN-MA, Mundinha Araújo (MELO, 2007). 
No Pará, iniciaram-se na década de 1980 os chamados mapeamentos de comunidades negras rurais. Estes mapeamentos foram efetivados, primeiramente, pelo Centro de Estudos e Defesa do Negro do Pará (CEDENPA), que contou com a colaboração de várias instituições, como a Empresa de Assistência Técnica e Extensão Rural (EMATER), a secretaria de educação, paróquias de vários municípios e, na década de 1990, da CPT e de sindicatos de trabalhadores rurais. Esses mapeamentos foram feitos a partir do que o movimento negro no Pará considerava "povoações constituídas eminentemente de pessoas negras". Neste processo o livro "O negro no Pará sob regime de escravidão", de Vicente Salles (1971), serviu como um guia para a militância do CEDENPA (TRINDADE, 2005).

A partir de 1988 iniciaram-se os Encontros de Raízes Negras realizados pelos moradores de comunidades negras do Baixo Amazonas paraense (Óbidos, Alenquer, Oriximiná e Santarém). Estes encontros tinham como objetivo debater questões sobre a realidade destas comunidades e surgiram a partir da ação dos integrantes da Associação Cultural de Óbidos (ACOB), entidade criada em 1987. O trabalho realizado por esta associação tornou possível a aproximação das comunidades que, até então, só se reuniam nos encontros paroquiais organizados pela Igreja Católica desde a década de 1970. Os dois primeiros Encontros de Raízes Negras incentivaram a criação de uma das associações de comunidades remanescentes mais atuantes do estado do Pará, fato que deu origem à Associação das Comunidades Remanescentes de Quilombos do Município de Oriximiná (ARQMO) (TRINDADE, 2005). Atualmente esses encontros se realizam em outras regiões do Pará, mobilizando inclusive quilombolas de outros Estados.

No Maranhão, durante o I Encontro de Comunidades Negras Rurais, realizado em 1986 em São Luis, cujo tema era "O Negro e a Constituição Brasileira”, foram elaboradas diversas propostas para a Constituinte com foco na questão fundiária, que já se configurava como a principal demanda destas comunidades. A partir desse encontro, o CCN-MA, em conjunto com o Centro de Estudos e Defesa do Negro do Pará (CEDENPA) e com o Movimento Negro do Rio de Janeiro, encaminhou a proposta sobre a garantia das terras das comunidades negras rurais à então Deputada Federal Benedita da Silva (PT-RJ), que a apresentou no Congresso Nacional. Além da Deputada Benedita da Silva, destacaram-se na Constituinte de 88 as presenças dos deputados federais Carlos Alberto de Oliveira Caó (PDT/RJ) e Paulo Paim (PT-RS) (MELO, 2007). O deputado Caó apresentou um texto que possuía a seguinte redação: "Fica declarada a propriedade definitiva das terras ocupadas pelas comunidades negras remanescentes de quilombos, devendo o Estado emitir-lhes os títulos respectivos. Ficam tombadas essas terras bem como documentos referentes à história dos 
quilombos no Brasil" (Grifos no original). Propostas contra a garantia da propriedade da terra também surgiram. Vale destacar a emenda apresentada pelo deputado Eliel Rodrigues (PMDB/PA) que desejava suprimir a questão da garantia da propriedade, que, porém, foi rejeitada.

A mobilização do movimento negro levou à aprovação do Artigo 68 do Ato das Disposições Constitucionais Transitórias (ADCT) da Constituição Federal de 1988, medida de caráter de reparação aos negros pela dívida histórica da sociedade brasileira para com a população afro-brasileira. Além das conquistas do Artigo 68 do ADCT e dos Artigos 215 e 216, o racismo passou a ser caracterizado como crime inafiançável e imprescritível, no Artigo $5^{\circ}$, inciso XLII, da CF 88 (MELO, 2007).

De acordo com Treccani (2006), o Artigo 68 introduz novas realidades no plano político e jurídico, na medida em que o direito à propriedade foi reconhecido a uma categoria coletiva. Apesar de o texto constitucional diferir do proposto pelos movimentos sociais quando garantiu a propriedade aos remanescentes das comunidades dos quilombos e não às comunidades negras remanescentes dos quilombos, ele deve ser entendido no sentido desta segunda expressão, pois permite ajustar a titulação às características destas comunidades.

Trata-se de um debate em torno das idéias de reparação, da abolição como um processo inacabado e da dívida que ainda hoje persiste para com os afro-brasileiros, tendo o termo quilombo, na atualidade, importante dimensão na luta. Nesse contexto, o conceito de quilombo passa a ser visto como um elemento aglutinador, capaz de expressar e de nortear as pautas consideradas cruciais para dar sustentação à afirmação da identidade negra ainda fragmentada pelo modelo de desenvolvimento do Brasil após a abolição da escravatura. Sendo assim, a expressão "remanescente das comunidades dos quilombos", que emerge na Assembléia Constituinte de 1988, não é tributária somente dos pleitos por títulos fundiários, mas de uma discussão mais ampla travada pelos movimentos negros e entre parlamentares envolvidos com a luta anti-racismo (LEITE, 2000).

\subsection{A regularização entre a interpretação das normas e conceitos}

O combate ao preconceito e a afirmação da igualdade racial não é algo novo na Constituição brasileira. Desde a constituição de 1934, em seu artigo 113, isto já era previsto. 
O mesmo dispositivo também foi previsto nas constituições de 1967 e 1969 (art. 153, § $1^{\text {o) }}$ (TRECCANI, 2006). Na Constituição de 1988, surgiu a expressão "remanescentes das comunidades dos quilombos", e o artigo 68 do Ato das Disposições Constitucionais Transitórias (ADCT) passou a prever: "Aos remanescentes das comunidades dos quilombos que estejam ocupando suas terras é reconhecida a propriedade definitiva, devendo o Estado emitir-lhes os títulos respectivos" (LEITE, 2000). A expressão surgiu associada ao reconhecimento da propriedade de suas terras.

Além do artigo 68 , existem os artigos $3^{\circ}, 5^{\circ}, 215^{\circ}$ e $216^{\circ}$ que precisam ser levados em consideração na interpretação do 68. Isto porque os mesmos também servem de instrumento nas reivindicações quilombolas. O $3^{\circ}$ apresenta como um dos objetivos da República a erradicação da pobreza e da marginalização, a redução das desigualdades sociais e regionais e a promoção do bem de todos, sem preconceitos de origem, raça, sexo, cor, idade e quaisquer outras formas de discriminação. Os demais artigos tratam da igualdade de todos perante a Lei, dos direitos, do acesso e da valorização da cultura e do patrimônio cultural dos grupos formadores da sociedade brasileira (TRECANNI, 2006).

Uma avaliação pertinente, compartilhada por diferentes lideranças do movimento negro, é a de que os setores conservadores, que votaram no artigo 68, acreditavam tratar-se de alguns pequenos casos isolados dos chamados remanescentes que estariam reivindicando a propriedade de suas terras. Inserir este direito na Constituição seria bom para produzir a visibilidade aos atos de governo e para colocar uma pedra definitiva em cima do assunto. Como hipótese, esta idéia não é inconsistente se forem consideradas as inúmeras dificuldades criadas para a aplicação do artigo assim que se percebeu: 1) a grande quantidade de áreas a serem tituladas no Brasil sob esta perspectiva, já que a população afro-descendente é numerosa; 2) o poder de mobilização e reorganização das comunidades motivadas pelo próprio artigo; 3) a evidência da definição de uma nova identidade para os descendentes de africanos no Brasil, por meio da possibilidade de sua inclusão, finalmente, na condição de brasileiros, de cidadãos, e 4) a viabilidade de ocorrerem titulações em grande parte das demandas desde então esboçadas (LEITE, 2000).

Apesar da importância do artigo 68, Leite (2000) chama atenção para o texto final que, ao falar em "remanescentes das comunidades dos quilombos" irá inicialmente dificultar a compreensão do processo de reconhecimento, criando vários impasses conceituais (quanto à identificação do fenômeno referido) e normativos (quanto à definição do sujeito do direito, os critérios, etapas e competências jurídico-políticas). Aquilo que advinha como demanda social, tornou-se restritivo por remeter à idéia de cultura como algo fixo, cristalizado, fossilizado e 
em fase de desaparecimento; à noção de remanescente como algo que não existe mais ou está desaparecendo, e à noção de quilombo como unidade fechada, igualitária e coesa. Além disso, o fato da expressão não corresponder à autodenominação destes mesmos grupos e o fato de tratar-se de uma identidade ainda a ser politicamente construída acabou suscitando muitos questionamentos em relação a sua aplicação concreta.

Segundo Arruti (2004) a categoria remanescente dos quilombos é de natureza jurídica e institui uma nova figura de direito, mas está sustentada numa categoria histórica confusa que é a de quilombo. $\mathrm{O}$ art. 68 orienta-se, portanto, por uma imprecisão, uma noção genérica, proposta como metáfora de resistência pelo movimento negro, no contexto de luta política, pela inserção da sua causa na Constituição. Para Leite (2000), o significado de quilombo que predominou nas interpretações acadêmicas e do senso comum foi a versão do Quilombo de Palmares como unidade guerreira constituída a partir de um suposto isolamento e auto-suficiência. Parecia difícil compreender uma demanda por regularização fundiária a partir de tal conceito. Diante disso, um esforço interpretativo do processo e da figura legal tornou-se uma exigência, sem o qual seria impossível a aplicabilidade jurídica do artigo. Foi necessário relativizar a própria noção de quilombo para depois resgatá-lo como inspiração política para os movimentos sociais contemporâneos.

A conceituação de quilombo da Associação Brasileira de Antropologia (ABA) ampliou, desde 1994, a visão das comunidades negras rurais existentes atualmente e conferiulhes uma maior pertinência em relação aos pleitos já formulados e aqueles que ainda estão por vir. Isto porque, para a $\mathrm{ABA}$, os quilombos contemporâneos consistem em grupos que desenvolveram práticas de resistência na manutenção e reprodução de seus modos de vida característicos num determinado lugar (BARROS, 2007). Todavia, precisava-se identificar o sujeito do direito e os critérios normativos para a regulamentação da lei e sua aplicabilidade, ou seja, os procedimentos e etapas a serem cumpridas para a titulação das terras e para o estabelecimento das responsabilidades e competências dos atores sociais envolvidos (LEITE, 2000).

No plano normativo, os processos de regularização fundiária, sobretudo quando operam em bases essencialistas, deparam-se com a dificuldade em identificar os sujeitos do direito, uma vez que os grupos revelam inúmeras estratégias para participarem de uma sociedade que é altamente hierarquizada e preconceituosa, como por exemplo a mestiçagem (LEITE, 2000).

Desta forma, o processo de definição do sujeito do direito desencadeou uma revisão dos critérios de classificação dos grupos que só foi adiante quando se deslocou para o 
processo no qual emergiu o grupo, levando-se em consideração as alianças de diferentes tipos e também as relações de consangüinidade, em que participam também indivíduos de outros grupos étnicos inseridos e identificados com as lutas dos afro-descendentes. Isto significou repensar o próprio grupo e a sua dinâmica de vida (LEITE, 2000).

Assim, no texto constitucional, é a comunidade o sujeito do direito, pois dela derivam os remanescentes, denominados posteriormente de quilombolas. $O$ que viria a ser contemplado nas ações seria então o modo de vida coletivo, a participação de cada um no diaa-dia da vida em comunidade. Trata-se, portanto, de um direito que se remete à organização social, diretamente relacionado à herança, à história e ao fenótipo, este último como um princípio gerador de identificação, pelo qual o casamento preferencial atua como um valor operativo no interior do grupo. A participação na vida coletiva e o esforço de consolidação do grupo são o que o direito constitucional deverá contemplar. Assim como deve contemplar também a capacidade de auto-organização e o poder de autogestão dos grupos para identificar e decidir quem é e quem não é membro da sua comunidade (LEITE, 2000). Dessa forma, a noção de coletividade é o que efetivamente conduz ao reconhecimento de um direito que foi desconsiderado. Coletividade no sentido de um pleito que é comum a todos, que expressa uma luta identificada e definida num desdobrar cotidiano por uma existência melhor, por respeito e dignidade (LEITE, 2000).

Nesta perspectiva, a reconstrução do espírito da lei vem requerer uma extensão da cidadania a todas as comunidades negras cuja resistência remonta a uma memória da escravidão passível de ser reconstituída pelas redes de parentesco e afinidade que conformam a malha do grupo. Desta forma, seria incoerente excluir alguns grupos que já foram expulsos de suas terras, pois permanecem articulados a uma mesma experiência e unidos, visando a autoproteção, atualizando as redes de sociabilidade por meio de várias formas de organização e articulações. É necessário também incluir desde as famílias que já se autodefiniam como remanescentes das comunidades dos quilombos até aquelas que têm as mesmas características, mas que não se autodenominam como tal, principalmente por não disporem de organização e meios para a formulação de um discurso articulado nos mesmos termos das que já se autodefiniam (LEITE, 2000).

Além da definição do sujeito de direito também foi preciso, para que o texto do decreto-lei pudesse surtir o efeito esperado pelos atuais pleiteantes, a elaboração dos procedimentos necessários à plena aplicabilidade do art. 68. Assim, precisou-se: 1) considerar a abrangência e a diversidade do fenômeno; 2) detalhar as fases do processo nas ações de reconhecimento e titulação; 3) definir as atribuições, competências e raio de ação de cada um 
dos órgãos envolvidos; 4) considerar as várias figuras jurídicas a serem aplicadas em caso de terras coletivas, individuais e modalidades mistas, e 5) enumerar os procedimentos necessários à resolução dos conflitos e respectivas formas de indenizações das partes envolvidas (LEITE, 2000).

$\mathrm{Na}$ definição do que seria quilombo, do sujeito do direito e dos procedimentos de titulação, responsabilidades e competências foram de encontro às diversas tentativas de regulamentação do artigo 68 em 1995, 1997, 1998 e 1999. Cada um destes elementos enfrentou forte discordância dos diferentes setores diretamente envolvidos, principalmente dos grupos interessados, e apontou a direção dos conflitos que vão desde a oposição às normas estabelecidas para as titulações até as pressões das elites econômicas interessadas nas terras ocupadas pelas comunidades negras, passando por disputas entre os órgãos do governo que teriam a atribuição para conduzir o processo (LEITE, 2000). De acordo com Arruti (2003), algumas vezes os sujeitos envolvidos buscaram reduzir as disputas que existiam entre eles a uma simples decisão de se classificar a questão quilombola como fundiária ou cultural.

As saídas que foram sendo vislumbradas pelos setores conservadores para dificultar os procedimentos necessários para a regularização são as mais variadas: a morosidade dos processos, a discussão interminável sobre de quem é a competência na condução do processo, a falta de investimento nas pesquisas para o conhecimento histórico-antropológico do assunto, a falta de sensibilização e informação para os funcionários das instituições governamentais responsáveis, como o Instituto Nacional de Colonização e Reforma Agrária (INCRA), do Ministério Público, Ministério da Justiça, Ministério da Cultura, Fundação Cultural Palmares (FCP) e outros. Alia-se a isto, sem dúvida, todo um conjunto de ações, enfatizadas pela mídia, com o intuito de transformar o chamado equivocadamente de remanescente em mais uma peça do folclore nacional (LEITE, 2000).

O paralelismo nas discussões que se desenvolveram entre o projeto de reforma agrária e a adoção de medidas de reparação histórica e cultural dirigidas à população negra fez com que a utilidade do artigo 68 para as demandas dessa população só fosse evocada alguns anos depois, em 1992, a partir dos conflitos vividos pelas comunidades de Frexal $^{1}$ (MA) e de Rio das Rãs (BA). A partir daí, feita tal conexão entre a demanda reprimida e a brecha legal na

\footnotetext{
${ }^{1}$ De acordo com Treccani (2006), nesta primeira tentativa de regularização das terras, o governo federal não expediu um título de reconhecimento de domínio, mas somente a concessão de direito real de uso. Pelo decreto n. ${ }^{\circ}$ 536, de 20 de maio de 1992, foi criada a Reserva Extrativista do Quilombo Frexal. Por isso, os quilombolas não consideram este caso como o primeiro título outorgado em cumprimento ao art. 68 do ADCT.
} 
Constituição, teve início um novo momento histórico para o debate sobre a questão racial no Brasil, no qual a população negra rural ganha grande visibilidade (ARRUTI, 2003).

O primeiro instrumento normativo criado foi a Portaria $\mathrm{n}^{\circ} 25$, de agosto de 1995 da Fundação Cultural Palmares (FCP). Também em 1995, por meio da portaria do INCRA no 307, o governo determinava a medição, demarcação e titulação de áreas de comunidades remanescentes dos quilombos localizadas em áreas públicas federais ou em áreas arrecadadas ou obtidas por processo de desapropriação, sob a jurisdição do órgão. Também estabelecia que o título de reconhecimento seria com cláusula "pro indiviso", na forma do que sugere o art. 68 do ADCT e, por fim, estabelecia que seria facilitada a criação do Projeto Especial Quilombola (TRECANNI, 2006). O estabelecimento destas duas portarias realizadas por órgãos diferentes demonstra a falta de definição e de clareza sobre quem teria a responsabilidade e competência para a realização da regularização.

Apesar das indefinições sobre competências e dos limites da portaria $n^{\circ} 307$ do INCRA, o órgão titulou, apenas no Pará, entre os anos de 1995 e 1998, seis territórios quilombolas, sendo um deles em parceria com o ITERPA, contemplando 567 famílias, em 18 comunidades, em uma área de 153.004,5960 ha, nos municípios de Oriximiná, Óbidos, Alenquer e Cachoeira do Piriá (INCRA, 2009). Para isso, o que prevaleceu foi a interpretação sobre a auto-aplicabilidade do artigo 68 (que em 1995 ainda era um tema controverso), assim como a concepção de que o reconhecimento desses grupos como remanescentes dos quilombos dependia apenas da sua auto-atribuição, o que dispensava a produção de laudos periciais comprobatórios. Estes só seriam realizados caso houvesse contestação da condição quilombola de algumas dessas comunidades (ARRUTI, 2003).

Em 1996, um Decreto Presidencial criou um grupo de trabalho para elaborar propostas de atos e procedimentos para a implementação do art. 68. Até 1999, uma série de propostas surgiu, oscilando quanto à entrega da competência de regularização entre INCRA e Fundação Cultural Palmares². Em outubro de 1999 é editada a medida provisória 1.911-11 através da qual o governo federal atribui a competência para implementação do art. 68 ao Ministério da Cultura, que realizaria este trabalho por meio da FCP (Portaria $n^{\circ} 447$, de 02/12/99). Esta Fundação foi criada pela Lei n. ${ }^{\circ} 7.668$ de 22 de agosto de 1988 e possui como uma de suas atribuições realizar a identificação das comunidades quilombolas, proceder ao

\footnotetext{
${ }^{2}$ As propostas que surgiram foram: proposta de decreto do grupo de trabalho criado em 1996, de 1997, que dá a atribuição para a FCP; proposta de decreto da Casa Civil, de 1999, que dá a atribuição para a FCP; Projeto de Lei do Dep. Paulo Mourão, de 2000, que dá atribuição para o INCRA, e proposta da Senadora Benedita da Silva, que também dá a atribuição para o INCRA (TRECCANI, 2006).
} 
reconhecimento, delimitação e demarcação das terras por eles ocupadas e conferir-lhes a titulação. Em 2000, esta fundação emitiu a portaria $n^{\circ} 40$ que passou a disciplinar o processo de reconhecimento (TRECANNI, 2006).

Em setembro de 2001, o decreto federal n 3.912, além de regulamentar as disposições relativas ao processo administrativo para identificação das comunidades quilombolas e para o reconhecimento, delimitação, demarcação, titulação e o registro imobiliário das terras por eles ocupadas, também veio consolidar a retirada de tal atribuição do INCRA. Com isso, a atuação do INCRA entre as comunidades quilombolas ficou restrita ao redirecionamento das ações e linhas de crédito regulares do órgão, já dirigidas aos assentamentos em geral (ARRUTI, 2003).

Essa transferência da competência da titulação para a FCP gerou inúmeras contestações de diversas comunidades quilombolas, do movimento negro e de diversas organizações não governamentais que viam um equívoco em considerar a regularização das terras quilombolas como uma questão prioritariamente cultural. $\mathrm{O}$ artigo 68 reconhece os direitos territoriais das comunidades, o que demonstra que a problemática é fundiária. Outro problema levantado foi o fato de a FCP não possuir recursos humanos nem financeiros para realizar todas as etapas acima descritas, tendo sido igualmente contestada a pretensão da mesma de "tutelar" os quilombolas (TRECCANI, 2006).

Além da transferência de órgão, outra crítica feita ao decreto $\mathrm{n}^{\mathrm{o}} 3.912$ foi a de que ele restringia o número de comunidades de quilombo que poderiam ter suas terras tituladas. Isto porque o decreto determinava que somente fossem tituladas as terras ocupadas por quilombos em 1888 e que estavam ocupadas por remanescentes das comunidades quilombolas em 10 de outubro de 1988, ou seja, no dia da promulgação da Constituição Federal. Treccani (2006) faz as seguintes indagações: como comprovar que estavam em 1888 quando o próprio governo brasileiro logo após a proclamação da República determinou a destruição dos documentos referentes à escravidão? Como exigir a presença na terra em 1988, quando muitas vezes estas comunidades estão envolvidas em sérios conflitos com fazendeiros e outros sujeitos, que fazem com que sejam expulsas de suas terras? Este decreto acaba por se mostrar inconstitucional na medida em que coloca uma série de restrições aos direitos que são conferidos pelo art. 68. Além disso, não deixou claro como ficaria a regularização das terras situadas sob domínio dos estados (TRECCANI, 2006).

Com o novo governo, em 2003, as atribuições de regularização continuaram com o Ministério da Cultura. Foi somente no fim deste mesmo ano que a competência para titulação 
saiu do âmbito da FCP e voltou para o INCRA por meio do Decreto $n^{\circ} 4.887^{3}$. Este decreto visava também regulamentar os procedimentos necessários para a identificação, reconhecimento, delimitação, demarcação e titulação das terras ocupadas pelos remanescentes das comunidades quilombolas.

Em 2008 foi aprovada uma nova Instrução Normativa de n. ${ }^{\circ}$ 49, de 29 de setembro, que regulamentou o procedimento para a titulação das terras ocupadas por remanescentes das comunidades dos quilombos de que tratam o Art. 68 e o Decreto $n^{\circ} 4.887$. De acordo com Chasin e Perutti (2009), a cada nova instrução normativa, o processo de titulação foi se tornando mais complexo, dificultando a sua conclusão.

Em diversos pontos as disposições trazidas pela nova norma afrontam os direitos das comunidades quilombolas, chegando a afastar-se e a contrariar as disposições contidas no decreto n. ${ }^{\circ} 4.887$, no que se refere à autodefinição, à realização do Relatório Técnico de Identificação e Delimitação (RTID), à consulta a órgãos públicos e entidades para verificar se o território quilombola não incide em áreas administradas por eles e à análise das contestações que possam ocorrer caso o território esteja em áreas pertencentes a estes órgãos e entidades ${ }^{5}$. Além destes problemas, esta aprovação foi precedida de uma consulta prévia aos quilombolas nos dias 15 a 17 de abril de 2008. Foi a primeira consulta prévia promovida pelo Governo Federal em cumprimento à Convenção 169, sobre Povos Indígenas e Tribais da Organização Internacional do Trabalho (OIT) ${ }^{6}$, que assegura, dentre outras disposições, que o critério para determinar a identidade de um povo indígena ou tribal é a "consciência de sua identidade". Garante também o direito à propriedade e posse de suas terras, estabelecendo a necessidade de consulta sobre todas as medidas que possam afetá-los (CHASIN; PERUTTI, 2009).

O objeto da consulta foi a minuta da Instrução Normativa n. ${ }^{\circ}$ 49. De acordo com Andrade (2008) esta consulta não pode ser considerada uma consulta livre, prévia e informada conforme assegurado pela Convenção 169 da OIT. Isto porque

[...] o processo de preparação da consulta foi marcado pela pressão da "urgência" por parte do governo o que comprometeu o seu caráter prévio e livre. Entende-se por prévia a consulta realizada antes da decisão e com o tempo necessário para que os povos interessados se posicionem. E a condição de consulta livre implica que o consentimento não deve estar sujeito a nenhuma forma de coerção ou manipulação externa (ANDRADE, 2008, p. 2, grifo da autora).

\footnotetext{
${ }^{3}$ Decreto n. $^{\circ} 4.887$, de 20 de novembro de 2003.

${ }^{4}$ Com este mesmo objetivo haviam sido publicadas as Instruções de n ${ }^{\circ} 16$, em 2004 e a de no 20, de 2005.

${ }^{5}$ Sobre as principais mudanças trazidas pela IN n. ${ }^{\text {4 }}$ 49/2008 ver (CHASIN; PERUTTI, 2009).

${ }^{6}$ Promulgada pelo Decreto n. ${ }^{\circ} 5.051$, de 19 de abril de 2004.
} 
Somente em 01 de outubro de 2008, cinco meses após o evento, é que foi publicada a nova instrução normativa o que, segundo a autora, evidenciou a falácia da urgência da consulta e limitou seriamente as possibilidades dos quilombolas negociarem um plano para a consulta prévia. A autora também destaca que o governo não cogitou discutir com os quilombolas as condições em que a consulta deveria ocorrer, de forma a garantir procedimentos apropriados do ponto de vista de ambas as partes (ANDRADE, 2008).

Este procedimento do governo federal fez com que 10 organizações quilombolas e 12 organizações não governamentais, por meio da Central Única dos Trabalhadores (CUT), protocolassem, ainda em 2008, junto à OIT, uma comunicação que denunciava que a referida consulta não ocorreu conforme disposto na Convenção 169 (ANDRADE, 2008).

O contexto de criação desta Instrução Normativa foi também marcado por intensas ofensivas ao Decreto n. ${ }^{\circ}$ 4.887. A primeira ofensiva partiu do então Partido da Frente Liberal (PFL), atual Democratas (DEM) que, em junho de 2004, ingressou no Supremo Tribunal Federal com a Ação Direta de Inconstitucionalidade (ADIN) n 3.239 contra este decreto, requerendo a sua impugnação. A ação questiona os critérios adotados para a identificação da condição quilombola e para a delimitação do território, bem como o uso do instrumento da desapropriação. Até março de 2009, esta ação ainda não havia sido julgada (CHASIN; PERUTTI, 2009).

Em 2007 os quilombolas foram alvo de campanha discriminatória, realizada pelo PFL, que divulgou dezenas de matérias em telejornais, revistas e jornais de grande circulação, acusando o Governo Federal de reconhecer e identificar falsos quilombos e extrapolar os direitos assegurados pela Constituição Federal. Além disso, em maio de 2007 o Deputado Federal Valdir Colatto (PMDB-SC) apresentou o projeto de Decreto Legislativo $n^{\circ}$ 44/2007 que visa sustar o Decreto $n^{\circ} 4.887 / 2003$, que regulamenta o procedimento para a titulação, com a justificativa de que este pretenderia regulamentar direta e imediatamente um preceito constitucional, o que seria inconstitucional. Tal projeto foi refutado por um parecer do Ministério Público Federal, com o principal argumento de que o artigo 68 é auto-aplicável e que o Decreto visaria apenas detalhar aspectos administrativos relacionados ao art. 68. Este mesmo Deputado é também autor do Projeto de Lei n ${ }^{\circ} 3654 / 2008$, que tem por objetivo regulamentar o artigo 68 de modo a restringir os direitos das comunidades quilombolas, alterando a definição de remanescentes dos quilombos, restringindo o direito à titulação às zonas rurais e possibilitando a titulação individual dos territórios (CHASIN; PERUTTI, 2009). 
Com todas estas pressões, um grupo inter-ministerial foi criado em julho de 2007 com o objetivo de fazer uma análise sobre os problemas referentes à demarcação de terras das comunidades quilombolas ${ }^{7}$. Este grupo, em um primeiro momento, propôs alterações ao Decreto n. ${ }^{\circ} 4.887 / 2003$, mas com as fortes reações contrárias dos quilombolas e da sociedade civil, o grupo reorientou seus trabalhos para a elaboração de um novo texto para a norma interna do INCRA. Esta reorientação teve como objetivo dissipar as reações contrárias ao decreto, de modo a mantê-lo intacto, mas sinalizou um recuo na defesa dos direitos das comunidades quilombolas (CHASIN; PERUTTI, 2009).

Com a elaboração e aprovação da Instrução Normativa INCRA n ${ }^{\circ}$ 49, em setembro de 2008, houve um grande retrocesso na garantia de direitos reconhecidos pela Constituição Federal, pela Convenção 169 da OIT e pelo Decreto 4.887/2003. O direito à autodefinição foi atingido, uma vez que a nova norma condiciona o início do processo de titulação à Certidão de Registro da FCP. Trata-se de claro desrespeito ao critério da "consciência de sua identidade", estabelecido no artigo 1.2 da Convenção 169 da OIT como definidor do pertencimento étnico (CPI-SP, 2009).

Em novembro de 2007, a FCP editou, sem que realizasse qualquer discussão pública com os interessados, nova regulamentação ${ }^{8}$ que instituiu o Cadastro Geral de Remanescentes das Comunidades dos Quilombos, dificultando o processo de inclusão de uma nova comunidade no cadastro da entidade (CHASIN; PERUTTI, 2009). Antes desta portaria era necessário somente apresentar uma declaração da comunidade afirmando ser quilombola e pedir a inclusão no cadastro. Com esta nova regulamentação passou a ser preciso ata de assembléia onde é aprovado esse reconhecimento; dados, documentos ou informações, tais como fotos, reportagens, estudos realizados que atestem a história comum do grupo ou suas manifestações culturais, e um relato sintético da trajetória comum do grupo (história da comunidade) para que a comunidade possa pedir a inclusão no cadastro.

Em outubro de 2009, as regras do INCRA foram novamente modificadas com a publicação da Instrução Normativa $n^{\circ} 56$, de 7 de outubro de 2009, que removia alguns dos empecilhos burocráticos ao reconhecimento. $\mathrm{O}$ movimento de avanço foi rapidamente contido

\footnotetext{
${ }^{7}$ Este grupo era composto por representantes da Casa Civil; Procuradoria-Geral da União; Secretaria Geral do Contencioso da Advocacia-Geral da União; Procuradoria-Geral Federal; Ministério do Desenvolvimento Agrário; Instituto Nacional de Colonização e Reforma Agrária; Secretaria de Promoção de Políticas para a Igualdade Racial; Fundação Cultural Palmares; Ministério do Meio Ambiente; Instituto Brasileiro do Meio Ambiente e dos Recursos Naturais Renováveis; Instituto Chico Mendes; Ministério da Justiça; Fundação Nacional do Índio; Gabinete de Segurança Institucional, Ministério da Defesa, entre outros órgãos (CHASIN; PERUTTI, 2009).

${ }^{8}$ Portaria FCP n ${ }^{\mathbf{0}} 98$, de 26 de novembro de 2007.

${ }^{9}$ Este cadastro foi instituído pela Portaria FCP n. ${ }^{\circ}$ 98, de 26 de novembro de 2007.
} 
e, 13 dias depois, a IN no 56 foi revogada e a IN 49, de 2008, foi republicada como IN no 57 de 20 de outubro de 2009 (CPI-SP, 2009). Isto somente demonstra o quanto não está sendo fácil garantir os direitos territoriais de diversas comunidades negras rurais dispersas pelo Brasil.

Com tudo isso, já se passaram mais de 20 anos após a constituição de 1988 e durante todo este período o jogo de forças se mostrou bem evidente tanto no campo jurídico como no político. Avanços e recuos nas normas jurídicas em relação ao reconhecimento das comunidades foram as marcas destes anos todos, mais recuos que avanços se formos analisar o que de fato foi feito pela regularização das chamadas terras de preto. Foram inúmeras portarias que foram impondo cada vez mais dificuldades e burocratizando cada vez mais o sonho da titulação das terras de milhares de famílias no campo brasileiro.

Assim como as dificuldades no debate sobre o reconhecimento das posses destas famílias é grande no âmbito nacional, também é grande o debate dentro das próprias comunidades interessadas na titulação. A heterogeneidade do processo de formação históricogeográfico destas comunidades negras rurais, os interesses dos diversos grupos envolvidos no debate em torno da regularização e a própria falta de entendimento sobre o que seria a titulação coletiva e do que seria um território quilombola, além da morosidade da titulação, fazem com que parte destas comunidades busquem outras formas de regularizar suas terras que não seja como remanescentes das comunidades dos quilombos. Este é o caso de duas das três comunidades aqui estudadas: Jutaí-Mirim, que se transformou em um Projeto de Assentamento, e Nova Esperança que tem suas terras em processo de regularização por meio do Programa Terra Legal Amazônia. A terceira comunidade denominada Campo Verde, apesar de todas as dificuldades já tratadas aqui, buscou a regularização por meio da criação de um Território Quilombola.

Nos próximos capítulos busco caracterizar cada uma destas comunidades com o objetivo de compreender a formação histórico-geográfica de cada uma delas e como estão conformados seus territórios hoje. 


\section{A EMERGÊNCIA DO TERRITÓRIO QUILOMBOLA}

\subsection{Como tudo começou: a descoberta}

Problemas que envolvem a posse da terra, na região onde estão situadas as comunidades em estudo, não são de hoje. De acordo com uma das lideranças quilombola, Antonina Santana, o confronto com fazendeiros pela posse da terra já existia desde a década de 1970. Além disso, problemas advindos do trabalho na agricultura, como o pouco rendimento da produção, fizeram com que na década de 1980 muitas famílias vendessem suas posses e se destinassem à cidade de Belém. Estes dois fatores contribuíram para o aumento do número de fazendas no município de Concórdia do Pará, principalmente às margens da rodovia PA 140, gerando o aumento da concentração fundiária e do desmatamento e o controle das nascentes dos igarapés pelos fazendeiros, já que as mesmas estão localizadas dentro das fazendas.

Paralelos ao avanço das fazendas, vários assassinatos de lideranças foram registrados, desde a década de 1970, sendo os citados por Antonina o assassinato do presidente do Sindicato de Trabalhadores Rurais de Tomé-Açu, Benedito Alves Bandeira (Benezinho), em 1984, e o de Virgílio Serrão Sacramento, ex-presidente do Sindicato de Trabalhadores Rurais de Moju em 1986. Tais fatos demonstram a gravidade do processo de concentração fundiária e do conflito advindo do mesmo. Foi neste contexto que foi criada a CPT/Guajarina, entre os anos de 1988 e 1989, com o retorno de Pe. Sérgio Tonetto para a Diocese de Abaetetuba, tornando-se vigário da Paróquia de Bujaru. Isto permitiu que sua atuação se ampliasse para todos os municípios pertencentes à diocese de Abaetutuba ${ }^{10}$ (CPT, 2008).

Pe. Sérgio Tonetto atuava no município de Moju, na microrregião de Concórdia do Pará, desde a década de 1970. Neste município realizava estudos junto aos camponeses sobre a situação fundiária, política e sindical de Moju, para que pudessem realizar a tomada do Sindicato dos Trabalhadores Rurais que estava nas mãos dos chamados "pelegos". Em 1983 este objetivo foi alcançado, porém a ameaça contra os trabalhadores continuou, culminando

\footnotetext{
${ }^{10}$ Os municípios que compõem atualmente a CPT Guajarina são Abaetetuba, Acará, Barcarena, Bujaru, Concórdia do Pará, Moju, Tomé-Açu e Tailândia e o mais recente, Maracanã, na região do Salgado. Pe. Sérgio Tonetto, fundador da CPT, completou, em 2007, 30 anos de atividades na Amazônia, iniciando pelo município de Moju. Faleceu no dia 4 de janeiro de 2008 na Itália (Irmã Rosa, coordenadora da CPT, entrevista concedida à autora em 07/04/2010).
} 
na morte de Virgílio e na ameaça de morte ao Pe. Sérgio que precisou se retirar da região, retornando somente no fim da década de 1980 (CPT, 2008).

Foi com a CPT/Guajarina que se iniciou a organização dos trabalhadores para a regularização das terras como pertencentes aos remanescentes das comunidades dos quilombos

[...] nessa época [...] a gente já fazia um trabalho com a evangelização ligada à realidade, ou seja, pregava a palavra de Deus, né, e trazia pra realidade do dia-a-dia [...] a gente já percebia que o evangelho deveria está presente na realidade não só na falação da pregação, mas que o evangelho deveria ser... isso quer dizer, que as lutas, o evangelho, a palavra de Deus deveria dá sustentação para que a gente pudesse trabalhar a organização e a luta, o fortalecimento da luta pelos direitos, pelos nossos direitos [...] (informação verbal)11.

Este trabalho de "evangelização ligada à realidade" era a forma como a CPT atuava junto às Comunidades Eclesiais de Base (CEBs).

Entre 1990 e 1991 foi implantado um projeto da CPT denominado de "Círculo de Cultura". Este era um trabalho de alfabetização de jovens e adultos com base na metodologia freiriana $^{12}$. De acordo com Brandão (2005), é "Circulo" porque todos ficam à volta de uma equipe de trabalho que possui um animador de debates alfabetizado que participa de uma atividade comum em que todos se ensinam e aprendem. É “de Cultura” porque, além de um aprendizado individual de saber ler e escrever,

o que o círculo produz são modos próprios e novos, solidários, coletivos, de pensar. E todos juntos aprenderão, de fase em fase, de palavra em palavra, que aquilo que constroem é uma outra maneira de fazer a cultura que os faz, por sua vez, homens, sujeitos, seres de história - palavras e idéias-chave no pensamento de Freire (BRANDÃO, 2005, p. 43-44).

Para Antonina:

[...] nós chamavamos de Círculos de Cultura porque nós trabalhávamos o resgate cultural, resgatava a história daquele povo e começamos a descobrir que naquela região ali, existia história de afros, existia história de remanescentes de quilombo [...] em Bujaru, Concórdia e outros municípios né, mais entre Bujaru e Concórdia [...] (informação verbal) ${ }^{13}$.

\footnotetext{
${ }^{11}$ Informação fornecida por Antonina Borges Santana, Fórum Social Mundial, Belém, 2009.

${ }^{12} \mathrm{Um}$ dos pressupostos do método é a idéia de que ninguém educa ninguém e ninguém se educa sozinho. A educação deve ser um ato coletivo e solidário e não pode ser imposta. As etapas pedagógicas de construção do método são as seguintes: o trabalho da fala (pesquisa do universo vocabular), o trabalho sobre a fala (as palavras geradoras) e a dimensão mais ampla (o tema gerador) (BRANDÃO, 2005).

${ }^{13}$ Informação fornecida por Antonina Borges Santana, Fórum Social Mundial, Belém, 2009.
} 
[...] descobrimos que São Judas Tadeu, no caso, existiu escravatura, descobrimos que o Cravo existiu escravatura, que o Santo Antônio também existiu, que Ipanema era o local aonde tinha mais negros né, também né, e daí sucessivamente nós fomo descobrindo as comunidade quilombola [...] (informação pessoal) ${ }^{14}$.

Como foi retratado acima, o debate em torno dos quilombos surge deste trabalho da CPT/Guajarina que possibilitou o surgimento da temática da escravidão. De acordo com Pe. Sérgio Tonetto, na década de 1990, aos poucos o debate sobre quilombos foi ganhando força nos grupos de evangelização da paróquia de Bujaru. No início não se tinha clareza a respeito dos quilombolas. Quando começou o trabalho de alfabetização de adultos, o mesmo não levava em consideração as especificidades históricas e culturais. Isto somente passa a ocorrer com o trabalho realizado nas comunidades Ipanema, Cravo, São Judas, Dona, Jutaí, Santo Antonio, dentre outras ${ }^{15}$.

Para a CPT, o trabalho com as CEBs e o trabalho de alfabetização de adultos foram as ações que possibilitaram o surgimento do discurso sobre a identidade negra. Porém, foi a alfabetização de adultos que possibilitou o espaço para que as histórias sobre a escravidão surgissem. ${ }^{16}$

No primeiro fascículo do Caderno Kizomba ${ }^{17}$ temos um relato realizado durante o trabalho do Círculo de Cultura na comunidade Sagrada Família, em Bujaru, que deixa evidente a presença do negro e do engenho na região e a relação com seus senhores:

[...] São Judas foi lugar de engenho e de muitos escravos. Os senhores de engenho conhecidos como Sr. Trovão e D. Senhorinha eram muito maus. Obrigavam seus escravos a sentarem nus em cima de pimenta, no banco da canoa, a fim de remarem com mais rapidez para o lugar onde seus senhores queriam chegar. Quando um negro passava na casa de Trovão e D. Senhorinha, tinha que passar em silêncio. Se passasse cantando ou assobiando, recebia como castigo passar o dia todo assobiando, cantando ou gritando. E se não cumprisse essa ordem apanhava até esmorecer. Os escravos passavam o dia todo trabalhando no pesado e se alimentando só de mingau de jerimum. D. Senhorinha também era muito má. Quando nascia uma criança de uma escrava, D. Senhorinha ia logo espiar. Se a criança fosse branca, ela, achando que era filho ou filha do seu marido, enchia-se de ciúme e colocava a criança no formigueiro para que morresse. Dizem os antigos que quando D. Senhorinha morreu, foi quase carregada pelas formigas que subiram pelo seu corpo e roeram até os seus olhos (CPT, 2003, p. 2).

\footnotetext{
${ }^{14}$ Antonina Borges Santana, entrevista à autora em nov./2005.

${ }^{15}$ Pe. Sérgio Tonetto, entrevista à Malcher (2006) em out./2006.

${ }^{16}$ Pe. Sérgio Tonetto, entrevista à Malcher (2006) em out./2006.

${ }^{17}$ Este caderno é composto por um conjunto de seis fascículos preparados pela CPT Guajarina, que estão sendo estudados pelas comunidades.
} 
O debate sobre a escravidão, sobre comunidades quilombolas, ampliou-se com o contato, por meio de encontros, com outras comunidades quilombolas que já estavam organizadas no estado do Pará. Em reuniões em Brasília, a CPT tem a informação que já existiam comunidades quilombolas mapeadas no município de Concórdia do Pará, como por exemplo, a comunidade Cravo. Mas os moradores desta comunidade não sabiam que estavam sendo considerados remanescentes das comunidades dos quilombos, como afirma Antonina.

Vemos então que a "descoberta" do ser quilombola acontece em dois momentos: no primeiro, localmente, temos o despertar de um passado de escravidão em um contexto de aprendizagem em que o termo quilombola não faz parte do discurso de quem fala da escravidão e a condição de escravo não é uma referência que dê bases para as reivindicações das famílias das diversas comunidades de Concórdia do Pará. No segundo momento desta "descoberta", em uma escala nacional, temos o despertar de uma consciência da existência de um sujeito de direito que passa a moblizar suas lutas tendo como base um novo elemento: o étnico, onde os termos quilombo/quilombola passam a fazer parte do discurso das lideranças destas comunidades, ganhando novos significados e servindo de elementos-chave para garantir a permanência das famílias na terra. A articulação local e nacional permite o início de um novo momento na vida destas famílias marcado pela presença constante da universidade, movimentos sociais e instituições governamentais estaduais e federais.

\subsection{A mobilização em prol do território quilombola}

Com esta "descoberta" iniciou-se, pela CPT, a mobilização nas diversas comunidades que ficam no entorno do rio Bujaru e de seus afluentes. De acordo com Antonina, foi um "trabalho formiga", pois foram em cada comunidade para discutir sobre a regularização das terras como remanescentes das comunidades dos quilombos. O trabalho foi desenvolvido nas comunidades Cravo, Curuperé, Santo Antônio, Dona, Campo Verde, Ipanema, Perpétuo Socorro, Castanhalzinho, Jutaí Grande, Jutaí-Mirim, nos municípios de Concórdia do Pará, e São Judas Tadeu, no município de Bujaru. Em cada uma destas comunidades foi tirada uma comissão para organizar reuniões, onde era primordial a discussão sobre o que eram os remanescentes das comunidades quilombolas, o que eram as terras quilombolas, sobre o tipo de titulação da terra (coletiva) e sobre os procedimentos para o reconhecimento jurídico e para 
a demarcação das terras para que pudessem usufruir dos subsídios do governo federal e, acima de tudo, garantir a propriedade de suas terras.

Colocaram-se inúmeras dificuldades no "trabalho formiga", principalmente quando as pessoas recebiam a notícia de que eram quilombolas:

[...] logo no começo, a gente se surpreendia muito porque, pelo fato da própria discriminação que a sociedade teve com os negros, os próprios negros no começo não se assumiam tá entendendo, depois que a gente começou a fazer o trabalho, eles achavam ridículo se considerar como negro, agora não, agora já tá muito mais claro pra nós né. As pessoas mesmo que já passaram por esse estudo, por reuniões, já não tem vergonha de se assumir como negro [isto ocorria] pelo fato que o negro era considerado, antigamente, como negro não tivesse direito a nada nessa sociedade, aquela discriminação racial né, tu é negro pronto, tu é considerado, não é nem negro era o preto, então o preto não tem vez, nem voz, é discriminado, então por esse fato que muitas pessoas não se assumia como negros né, sentia horror de a gente chamar, dizer que a pessoa era negra (informação pessoal). ${ }^{18}$

Esta mobilização foi realizada até mesmo em comunidades formadas a partir da década de 1970, com a abertura da PA 140 que atravessa o município de Bujaru e Concórdia do Pará de norte a sul, paralelamente ao rio Bujaru. A justificativa era de que, por diversas circunstâncias, os moradores das comunidades mais antigas precisaram migrar para outras áreas, ou de uma comunidade para outra ou para a margem da rodovia. Esta migração não seria motivo para que estas comunidades, formadas recentemente, mas compostas por pessoas das proximidades, não tivessem direito de ter suas terras tituladas como pertencentes aos remanescentes das comunidades dos quilombos.

Nas reuniões, denominadas de "Reunião em terra de remanescente de quilombo" ou "Assembléias de Autodefinição", que ocorriam em cada comunidade, havia o estudo da cartilha "Minha Terra: meus direitos, meu passado, meu futuro". Ela foi elaborada em 1998 pela Associação das Comunidades Remanescentes de Quilombos do Município de Oriximiná (ARQMO) e pela Comissão Pró-Índio de São Paulo (CPI-SP). Esta cartilha foi muito utilizada nas comunidades do estado do Pará para ajudar nas discussões sobre o art. 68. Além disso ela também ensinava os procedimentos para conseguir o título da terra e como ocorria a tramitação do processo no INCRA.

Além do estudo, havia na reunião uma votação para ver quem concordava em se autodefinir quilombola. Caso houvesse a concordância da maioria, três pessoas assinavam o pedido formal da titulação e depois se preenchia um formulário com os dados da comunidade

\footnotetext{
${ }^{18}$ Antonina Borges Santana, entrevista à autora em nov./2005.
} 
e se fazia um croqui da mesma. Cabia à CPT encaminhar a Ata da assembléia, a declaração de autodefinição, o formulário e o croqui para o ITERPA (CPT, 2000).

Em 1999, após identificar as comunidades que apresentavam relatos de escravidão, a CPT/Guajarina encaminhou um pedido à Secretaria de Estado de Ciência, Tecnologia e Meio Ambiente (SECTAM) para a realização de um estudo sobre as comunidades dos municípios de Abaetetuba, Acará, Bujaru e Moju.

Em Concórdia do Pará, o primeiro passo dado em busca da titulação das terras como propriedade coletiva foi dado pelas comunidades Dona e Santo Antônio, em 22/06/2000; Curuperé, em 24/06/2000 e Cravo em 26/06/2000. Nas atas destas reuniões somente houve voto contra o reconhecimento nas comunidades Curuperé (16 votos e até 2009 ainda não havia sido reconhecida) e Santo Antônio (um voto, mesmo assim foi reconhecida ${ }^{19}$ ).

O fato de não haver voto contra na assembléia não quer dizer que todos da comunidade aceitam. Isto fica evidente até hoje em comunidades como o Cravo, onde apenas houve 21 pessoas presentes na assembléia, do universo de cerca de 100 famílias que residiam na época na comunidade. Ainda em 2000, Dona, Santo Antônio, Curuperé e Cravo já apareciam na lista do Programa Raízes, do governo do estado, identificadas como quilombolas. Neste mesmo ano, em agosto, a CPT encaminhou pedido ao ITERPA para abertura de processo administrativo para o reconhecimento destas comunidades e outras 10 que ficam na sua região de atuação (CPT, 2000).

Neste mesmo ano, o ITERPA realizou as vistorias nas comunidades solicitadas e, em julho de 2001, comunicou que as comunidades estavam localizadas em terras da União e não do estado do Pará, e que por isso não poderia continuar com o processo de regularização. Mesmo assim, a CPT encaminhou diversos documentos sobre as quatro comunidades e pediu que fossem analisados, que fosse feito o levantamento cartorial, que fosse revisto o parecer jurídico que sugeria o indeferimento do pedido de regularização, encaminhando mais duas comunidades para a realização de vistoria, as comunidades Ipanema e Campo Verde (CPT, 2001a). Assim, foram seis as comunidades que se declararam quilombolas e buscaram a regularização de suas terras dessa forma.

A CPT era então a principal e talvez a única mediadora entre as famílias e o ITERPA, situação que pareceu se modificar ainda em 2001 com o surgimento de novos mediadores. Isto possivelmente pode ser compreendido pelo fato de terem ocorrido algumas mudanças estruturais na CPT/Guajarina que demandaram uma dedicação maior à Comissão.

\footnotetext{
${ }^{19}$ Não obtive informações sobre o que ocorreu com a família que votou contra.
} 
Em 1997, após a morte de Dom Angelo Frosi em 1995, quem assumiu a diocese foi Dom Flávio Giovenale, $\mathrm{SDB}^{20}$. Com o novo bispo, a $\mathrm{CPT}$, que inicialmente era vinculada à Diocese de Abaetetuba, desvinculou-se da mesma por desentendimentos com o bispo, ficando sem vínculo com dioceses. Sem estrutura nenhuma, as irmãs da Congregação Sagrado Coração de Jesus doaram uma parte do sítio onde funciona o convento, no município de Ananindeua, vizinho a Belém, para que lá se construísse a nova sede da CPT. Sua área de atuação continuou sendo a mesma da diocese de Abaetetuba, porém, sem vínculo com a mesma.

Como novos mediadores surgiram no período de 2000-2001 o Movimento dos Trabalhadores Sem Terra (MST) e o Movimento de Pequenos Agricultores (MPA), como sugestão do MST. A proposta era de que, como o MPA atuava junto aos camponeses que possuíam terra, ele poderia contribuir melhor com as ações junto aos órgãos estaduais e federais. O MPA passou então a atuar junto às comunidades, representado por Antonina, que havia deixado a CPT e ingressado no MPA neste período.

Em agosto de 2001, na vila Santana, município de Bujaru, foi realizada uma reunião com a presença de 117 pessoas, onde foi decidida a criação de duas associações quilombolas, uma no município de Bujaru e outra em Concórdia do Pará, ambas com o objetivo de buscar a regularização das terras quilombolas de seus respectivos municípios (CPT, 2001b). Desta forma, em 22 de dezembro de 2001, na comunidade de Santo Antonio, realizou-se a assembléia de fundação da Associação Remanescente de Quilombos Nova Esperança de Concórdia do Pará (ARQUINEC) ${ }^{21}$. Estavam presentes moradores das comunidades Cravo, Curuperé, Campo Verde, Dona, Ipanema e Santo Antônio ${ }^{22}$. Esta associação tem como objetivo administrar as terras ocupadas e de propriedade das famílias das comunidades e representá-las nos seus interesses. Estas terras, depois do reconhecimento, não poderão ser vendidas, arrendadas ou loteadas, deverão ser utilizadas pelos associados para que produzam para o seu auto-consumo de forma auto-sustentável, sendo que podem ser utilizadas por moradores de outras comunidades remanescentes de quilombo desde que autorizados pela associação e desde que seja respeitado o seu estatuto (INCRA, 2005).

As famílias de Concórdia do Pará passaram a ter sua própria organização e por meio dela passaram a assumir diretamente a relação com o poder público. A senhora Antonina

\footnotetext{
${ }^{20}$ Salesiano Dom Bosco

${ }^{21}$ Apesar do nome da associação ser Nova Esperança, a comunidade aqui estudada denominada Nova Esperança não faz parte da associação

${ }^{22}$ Uma associação pode representar uma ou mais comunidades.
} 
afirma que as famílias começaram a se organizar e a defender seus direitos quando compreenderam que era melhor lutar enquanto quilombola, pois teriam acesso às políticas governamentais voltadas aos quilombolas e que a titulação sairia mais rapidamente ${ }^{23}$.

Neste novo cenário, a CPT passou a atuar na formação das comunidades sobre a valorização do negro por meio do estudo da história da África, da escravidão e da cultura africana. É um trabalho diferente do Círculo de Cultura, pois não visa à alfabetização. Tal ação, porém, ocorre de forma muito lenta e com dificuldade pois depende da capacidade de articulação e mobilização da ARQUINEC que, desde sua criação, cada vez mais ganha autonomia para resolução das questões referentes à regularização das terras, tendo a CPT mais a função de assessora do que de mediadora das reivindicações das famílias (Foto 1).

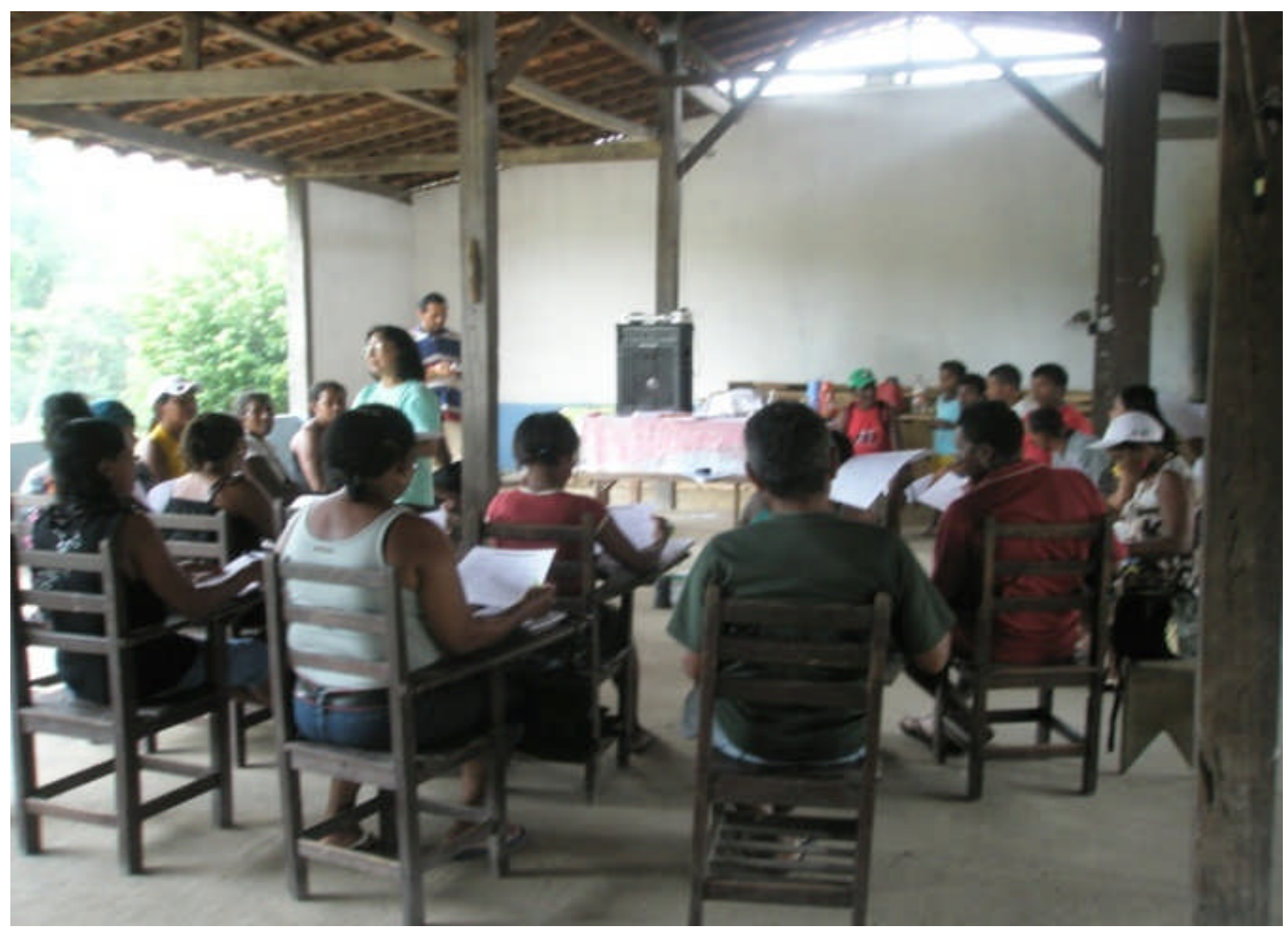

Foto 1: Formação da CPT, na comunidade Santo Antônio, Concórdia do Pará. Os participantes são camponeses de diversas comunidades. Em pé temos a irmã Rosa, da CPT/Guajarina (foto da autora em out./2008).

A ARQUINEC prosseguiu com os trabalhos nas comunidades e, em janeiro de 2004, passaram a fazer parte da associação famílias das comunidades Nossa Senhora do Perpétuo Socorro e Santa Luzia do Castanhalzinho, totalizando oito comunidades. Ainda em janeiro de 2004, foi apresentado em assembléia da ARQUINEC o estudo realizado pela Universidade

\footnotetext{
${ }^{23} \mathrm{O}$ que de fato não ocorreu, pois as comunidades foram vistoriadas em 2005 e somente em 2010 receberam a titulação.
} 
Federal do Pará (UFPA) sobre o processo de ocupação no entorno do rio Bujaru, e mais especificamente sobre a comunidade São Judas, no município de Bujaru. Este estudo foi utilizado como parte do relatório de identificação das comunidades Ipanema, Campo Verde, Santo Antônio e Dona elaborado pelo INCRA em 2005.

Nos meses de abril a junho de 2004, foram feitas reuniões em outras comunidades que ainda não haviam realizado a assembléia para a auto-definição, para que fosse possível formalizar o pedido de titulação coletiva das comunidades como "remanescente de quilombo", junto ao INCRA. Dentre as comunidades visitadas estavam as de Jutaí-Mirim e Campo Verde, com reuniões realizadas, respectivamente, nos dias 10 e 14 de abril de 2004 (MALCHER, 2009).

Todas as reivindicações pela titulação das terras eram inicialmente encaminhadas para o ITERPA, até que este instituto informou em 2001 que a regularização das terras onde estavam situadas estas comunidades não era de sua competência. Neste período, a competência para a titulação era da Fundação Cultural Palmares. Somente em 2004, quando a competência passou a ser do INCRA, é que houve uma nova organização da documentação para ser encaminhada a este órgão. Com isso, todo o trabalho já feito anteriormente e encaminhado para o ITERPA precisou ser refeito.

Em 2005 foi encaminhada à Fundação Cultural Palmares a declaração em conjunto de autodefinição das comunidades Santo Antônio, Igarapé Dona, Campo Verde e Ipanema (INCRA, 2005) e, em agosto do mesmo ano, uma equipe técnica do INCRA esteve na região com o objetivo de fazer o levantamento ocupacional, cartorial e topográfico das áreas. De acordo com Antonina, este levantamento foi cercado de conflitos entre as lideranças quilombolas e o INCRA, pois a associação indicava as comunidades que deveriam ser vistoriadas, mas o INCRA somente vistoriou aquelas em que identificou um consenso entre os moradores sobre a titulação coletiva. Desta forma, a identificação e a delimitação das áreas realizadas pelo INCRA somente foram concluídas nas comunidades de Santo Antonio, Ipanema, Igarapé Dona e Campo Verde, onde todas as famílias aceitaram a titulação das terras na categoria coletiva. Reavaliando esta ação do INCRA, Antonina acredita que foram ludibriados pelo órgão, que não deveriam ter aceitado o reconhecimento somente destas comunidades e que se deveria ter exigido a titulação para todas em um mesmo processo.

No Memorial Descritivo realizado, o INCRA registrou a área pretendida pela associação como Área Total Levantada, mas somente considera como Área Proposta para Reconhecimento a das quatro comunidades vistoriadas (INCRA, 2005). Esta Área Total Levantada (10.838,8738 ha) abrange parte dos municípios de Bujaru e de Concórdia do Pará 
(Figura 1), está situada nas Glebas Bujaru e Araxiteua e é atravessada pela rodovia PA 140 a oeste, pela estrada vicinal Transjutaí a leste, e ao meio pelo rio Bujaru.

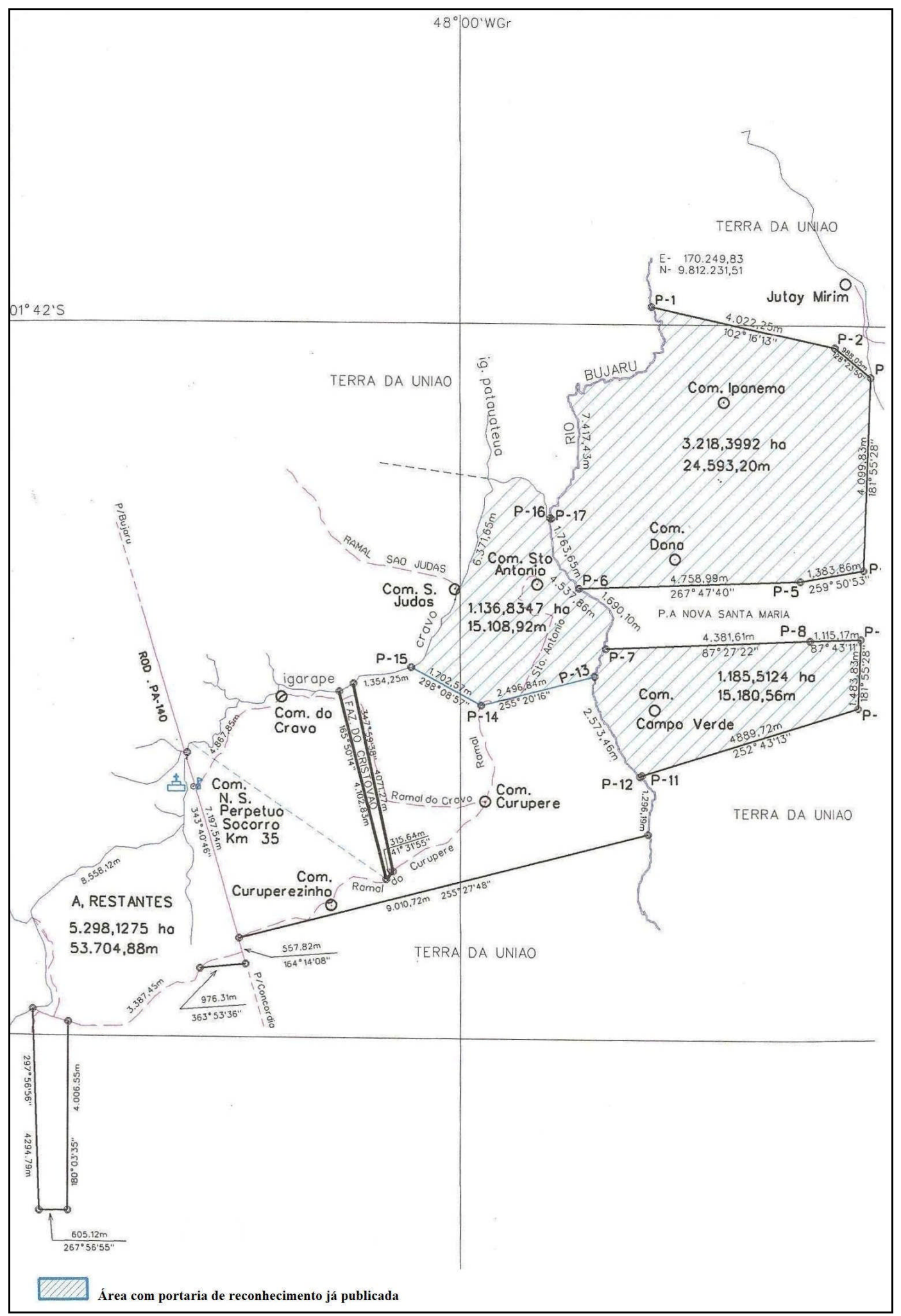

Figura 1: Área quilombola identificada por associações quilombolas e localização da área reconhecida como Território Quilombola onde se localiza Campo Verde.

Fonte: INCRA, 2005 
A Área Proposta para Reconhecimento possui um total de 5.802,1703 ha, onde moram 180 famílias, totalizando 975 pessoas. Limita-se ao norte com as terras da União e com o Igarapé Cravo e, ao sul, com terras da União, ao leste, com terras da União e o assentamento Santa Maria, e a oeste, com o Igarapé Cravo e o Rio Bujaru. Este Território está inserido no Perímetro da Gleba Bujaru, discriminada administrativamente, arrecadada por meio da Portaria INCRA/DF/92, de 13 de dezembro de 1999 e matriculada sob o $\mathrm{n}^{\circ}$ 4.424, do Livro2Z, Fls. 73, em nome da União Federal, no Cartório de Registro de Imóveis de Santa Izabel/PA (INCRA, 2005).

Os lotes ocupados dentro das comunidades vistoriadas encontravam-se medidos e demarcados topograficamente, estando 34 com Títulos Provisórios (Licença de Ocupação) e 11 com Títulos Definitivos expedidos pelo INCRA antes do processo de reconhecimento.

Estas quatro comunidades vistoriadas fazem parte de um grupo de nove comunidades $^{24}$ que recebeu a certificação da Fundação Cultural Palmares em 2006. Neste mesmo ano eram $14^{25}$ as comunidades que se autodefiniram como quilombolas (BRASIL, 2006).

A “descoberta", por parte dessas comunidades, da possibilidade de serem consideradas quilombolas, desde 2001, levantou muitos debates nas comunidades de Concórdia do Pará. À primeira vista, essa notícia gerou conflitos de interesses dentro das comunidades e fora, envolvendo o Sindicato dos Trabalhadores Rurais de Concórdia do Pará (STR), o MPA, a ARQUINEC e o INCRA. Dentro das comunidades existiam moradores que aceitavam a titulação coletiva, enquanto outros não. O STR de Concórdia do Pará não concorda com essa categoria de titulação, apoiado, segundo alguns entrevistados, por alguns servidores do INCRA que eles identificam como sendo de Tomé-Açu. Ao lado das comunidades que queriam o reconhecimento estavam a ARQUINEC, o MPA, a CPT e também alguns servidores do INCRA de Belém.

Justamente devido às resistências encontradas foi que a CPT e depois a ARQUINEC consideraram ser importante um trabalho de formação junto a estas comunidades sobre o que é quilombo e o que é ser quilombola, pois era necessária a construção e o reconhecimento de uma identidade quilombola que se forjava por uma necessidade da luta pela garantia de suas terras, o que faz com que esta identidade tenha uma dimensão política estratégica, além de

\footnotetext{
${ }^{24}$ Nova Esperança (cadastrada como Velho Expedito), Cravo, Campo Verde, Timboteua Cravo, Perpétuo Socorro, Santo Antonio, Dona, Curuperé e Ipanema.

${ }^{25}$ Castanhalzinho, Nova Esperança, Curuperezinho, Curuperé, Perpétuo Socorro, Cravo, Santo Antonio, Dona, Campo Verde, Ipanema Alto e Baixo, Jutaí Grande, São Raimundo, Km 51, e em abril de 2007, também se autodefiniu como "remanescente de quilombo" a comunidade Pernambuco.
} 
territorial. Também houve a necessidade da compreensão do porquê da titulação ser coletiva. Foi neste momento que se iniciou o "trabalho formiga".

Diversos foram os motivos para a aceitação da titulação coletiva como, por exemplo, o alto custo para se tirar um titulo de forma individual; o receio de que alguém de fora das comunidades, como os fazendeiros e empresários do dendê, pudesse tomar as terras que não possuem titulação; a crença de que o procedimento para a regularização da terra como coletiva seria mais rápido, assim como a concessão dos benefícios que podem ser obtidos com esta regularização.

Uma distinção é feita entre a titulação individual e a coletiva. Segundo uma das lideranças quilombolas, com a titulação coletiva não há a possibilidade das terras serem vendidas, ou seja, estas estariam fora do mercado de terras, enquanto que a titulação individual abre a possibilidade para estas vendas e para a entrada de fazendeiros em terras que antes eram de membros das comunidades.

Antonina esclarece que o conhecimento da existência do decreto n. ${ }^{\circ} 4.887$, que regulamenta os procedimentos para a titulação das terras quilombolas, e do Programa Brasil Quilombola $^{26}$ contribuiu para uma maior mobilização por parte da ARQUINEC junto às comunidades para a titulação coletiva. Apesar de Antonina ver de maneira positiva o decreto e o programa, o INCRA já não é visto da mesma maneira. O órgão é percebido como um grande problema para os quilombolas, pois dificulta cada vez mais a regularização das terras. Outro problema colocado por Antonina a respeito das lutas dos quilombolas são as acusações e calúnias que os quilombolas recebem na reivindicação pela terra coletiva.

Isto porque, enquanto se observa nas terras de Concórdia do Pará um movimento no sentido de regularizar as terras como pertencenste aos remanescentes das comunidades dos quilombos, também existe um outro movimento no sentido de garantir a propriedade individual das terras. Nas mesmas comunidades onde havia um trabalho da ARQUINEC também existiam pessoas que articulavam as comunidades no sentido de não aceitar a titulação coletiva. Assim sendo, desde 2005 se observa progressivamente a adesão de algumas comunidades à proposta de regularização fundiária através de Projetos de Assentamento (PA), como foi o caso Jutaí Mirim e, a partir de 2009, a regularização fundiária por meio do Programa Terra Legal Amazônia, como está ocorrendo em Nova Esperança.

\footnotetext{
${ }^{26}$ Este programa objetiva realizar ações que visam melhorar a qualidade de vida e de organização das comunidades remanescentes de quilombos, além de garantir o acesso ao conjunto de bens e serviços sociais necessários ao seu desenvolvimento. Para isso, busca a ação conjunta com organismos do governo federal, em especial o MDA/INCRA, o Ministério do Desenvolvimento Social e Combate à Fome e o Ministério da Cultura/Fundação Cultural Palmares, entre outros ministérios com atribuições definidas no Decreto $n^{\circ} 4.887$.
} 
No capítulo que se segue apresento as três comunidades aqui estudadas e suas respectivas soluções encontradas para a regularização de suas terras. 


\section{AS DIFERENTES PROPOSTAS DE REGULARIZAÇÃO FUNDIÁRIA: E O TERRITÓRIO QUILOMBOLA?}

Em Concórdia do Pará houve um intenso trabalho no sentido de regularizar as terras de diversas famílias, em diversas comunidades e de forma coletiva, como comunidades remanescentes de quilombos. Todavia, assim como foi intenso também o conflito de interesses entre, de um lado, o STR, a Prefeitura do Município de Concórdia do Pará e o INCRA e, de outro, a ARQUINEC e a CPT. Isto fez com que diversas comunidades enveredassem por diferentes caminhos na busca pela titulação de suas terras. Serão apresentadas aqui três diferentes propostas de regularização fundiária, a saber, como Território Quilombola, opção adotada pela comunidade Campo Verde; como Projeto de Assentamento, opção adotada pela comunidade Jutaí-Mirim e Programa Terra Legal Amazônia, opção adotada pela comunidade Nova Esperança. O objetivo é elucidar a diversidade de formas de regularização das terras e compreender como as diversas relações entre comunidade e outros grupos a elas externos acabam por intervir na escolha dos camponeses sobre a melhor forma de regularizar suas terras.

\subsection{O Território Quilombola e Campo Verde}

\subsubsection{A regularização dos territórios quilombolas no Brasil}

\subsubsection{Quilombolas do Brasil: um longo caminho a trilhar}

O Território Quilombola é instituído pelo governo federal a partir de uma série de procedimentos que foram variando de portaria em portaria desde a constituição de 1988. Estima-se que existam hoje no Brasil cerca de 3.000 comunidades quilombolas (CPI-SP, 2010). Destas, apenas 1.439 comunidades foram certificadas pela FCP (FCP, 04/2010). Até 2009, apenas 177 comunidades quilombolas, com 11.241 famílias, haviam recebido o título de suas terras, abrangendo uma área de 960.010,81ha (INCRA, 06/04/2010). Este número 
representa apenas $12,30 \%$ das comunidades certificadas, ou seja, a atuação do INCRA e dos órgãos responsáveis pela regularização das comunidades reconhecidas como remanescentes de quilombos nos diferentes estados está muito longe do que se esperava.

O número de títulos expedidos até 2009 por diversos órgãos estaduais e federais em 14 estados é de $110^{27}$, através dos quais foram criados 101 territórios quilombolas. Todavia existem mais 10 outros estados onde existem comunidades certificadas pela FCP, com exceção do Acre, Roraima e o Distrito Federal, que ainda não tiveram seus territórios titulados $^{28}$. O estado com maior número de certidões emitidas é o estado da Bahia, porém o estado que possui maior número de titulações é o estado do Pará, único estado onde até 1998, havia terras regularizadas de acordo com o art. 68.

Do total dos 110 títulos expedidos até 2009, sete títulos regularizando seis territórios quilombolas foram expedidos de 1995 a 1998 (sendo somente um título estadual). De 1999 a 2003 foram 45 títulos emitidos, regularizando 42 territórios (sendo 31 títulos estaduais). A partir de 2004, foram expedidos 58 títulos regularizando 53 territórios quilombolas (sendo 48 títulos estaduais) (Gráfico 1).

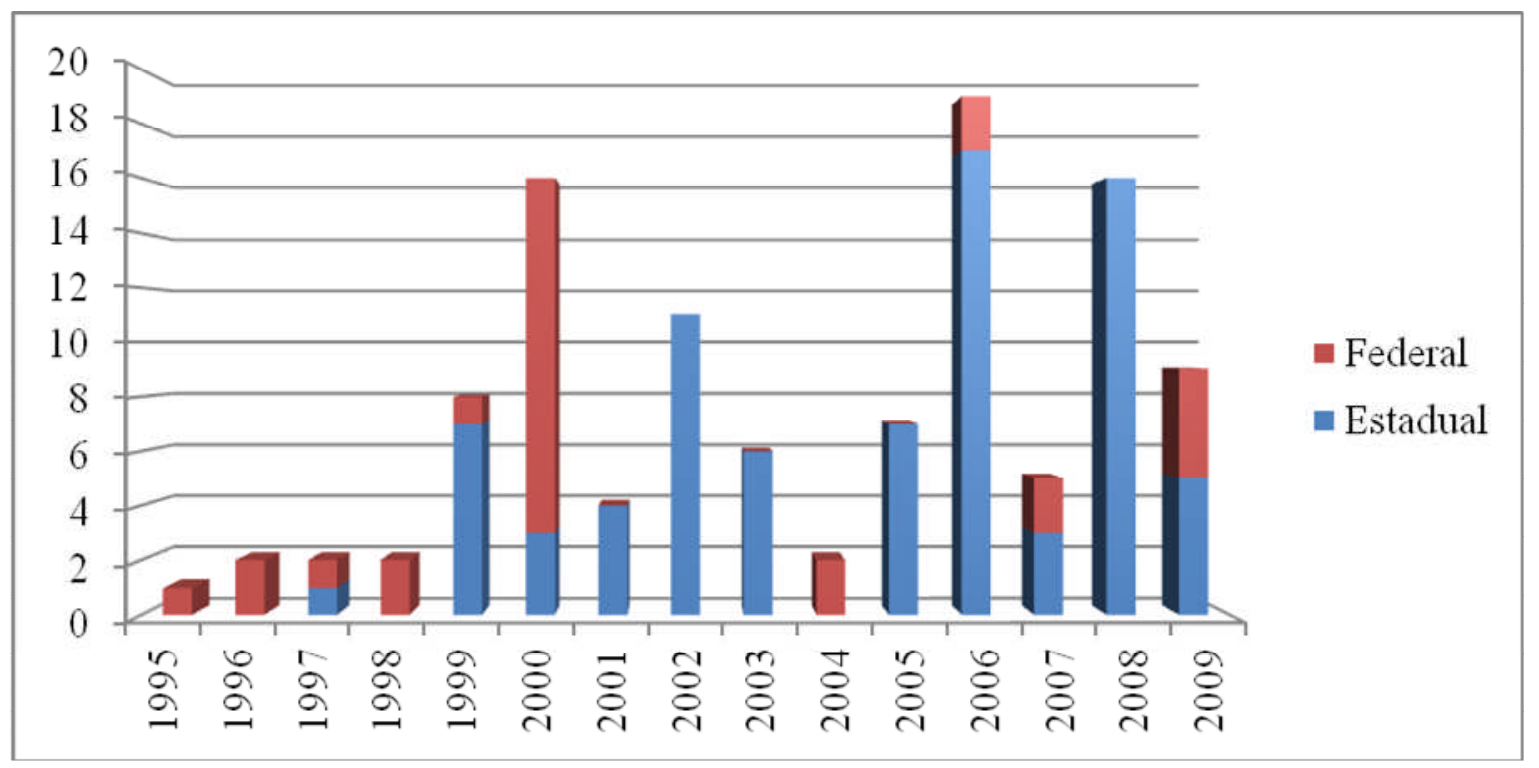

Gráfico 1: Número de títulos expedidos no Brasil por ano e por órgão (1995 - 2009).

27 Bahia, Maranhão, Minas Gerais, Pernambuco, Pará, Mato Grosso, Rio Grande do Sul, São Paulo, Piauí, Goiás, Rio de Janeiro, Amapá, Mato Grosso do Sul e Sergipe.

28 Alagoas, Paraná, Paraíba, Espírito Santo, Ceará, Tocantins, Rio Grande do Norte, Santa Catarina, Rondônia e Amazonas. 
Sobre a competência da titulação em terras da União, de 1995 a 1998, apesar da indefinição sobre a quem caberia a titulação, quem titulou foi o INCRA; de 1999 a 2003, a competência foi dada à FCP, e de 2004 em diante passou a ser novamente do INCRA, de acordo com o Decreto 4.887/2003.

Em 1997 a titulação estadual foi realizada pelo ITERPA através de parceria, técnica e/ou financeira, com o INCRA/MDA. Em 1999, a FCP começou a titular, mas somente um título foi emitido por ela, os outros dois foram expedidos por órgãos estaduais em parceria com ela. Em 2000, a maioria dos títulos foi emitida pela FCP. Apesar da competência ser desta fundação, o ITERPA emitiu um titulo com a parceria do INCRA. A partir deste ano, como podemos observar no Gráfico 1, a FCP não titulou mais, apesar da titulação ter permanecido de sua competência até 2003.

As titulações realizadas pela FCP foram consideradas problemáticas, pois, de acordo com Treccani (2006), os processos ex-ofício só poderiam tramitar com a prévia autorização do ministro da cultura, o que atrasava sua tramitação. Alguns títulos expedidos incidem em propriedades particulares que não foram desapropriadas ou cujos títulos não foram cancelados. Esta situação foi, possivelmente, o principal problema, além da falta de recurso para indenização de benfeitorias, o que estimulou os conflitos entre os envolvidos.

De acordo com o INCRA (06/01/2010), existem nove territórios titulados em 2000 sem a retirada ou indenização dos ocupantes não quilombolas (proprietários e/ou posseiros) ${ }^{29}$, o que corresponde a 289.651,3119ha.

Desde 1999, podemos observar a crescente participação dos estados na regularização das terras. O INCRA pouco titulou, e em alguns anos, nem titulou. Todavia, em muitos títulos emitidos pelos institutos estaduais, o INCRA aparece, principalmente desde 2005, como parceiro técnico e/ou financeiro, principalmente do ITERMA (2005 - 2006), do ITERPA (2007 - 2008) e do INTERPI (2006 - 2008). De 1995 a 2009 os institutos estaduais emitiram 80 títulos e os federais somente 30 (Tabela 1).

\footnotetext{
29 Castainho e Conceição das Crioulas (PE), Furnas da Boa Sorte (1º́tulo) (MS), Ivaporunduva (1º́tulo) (SP), Kalunga (GO), Mata Cavalo (MT), Mocambo (SE), Porto Coris (MG), Santana (RJ) (INCRA, 06/01/2010).
} 
Tabela 1 - Títulos expedidos e a Área titulada por órgão (1995 - 2009)

\begin{tabular}{|c|c|c|c|c|}
\hline Órgão & $\begin{array}{c}\mathbf{N}^{\mathbf{0}} \text { de } \\
\text { Títulos }\end{array}$ & $\%$ & $\begin{array}{c}\text { Área Titulada } \\
\text { (ha) }\end{array}$ & $\%$ \\
\hline \multicolumn{5}{|l|}{ Federal } \\
\hline INCRA & 14 & 12,73 & $110.779,61$ & 11,54 \\
\hline FCP & 14 & 12,73 & $320.910,49$ & 33,43 \\
\hline SPU & 2 & 1,82 & $9.580,34$ & 1,00 \\
\hline Subtotal & 30 & 27,27 & 441.270,44 & 45,97 \\
\hline \multicolumn{5}{|l|}{ Estadual } \\
\hline CDA-BA / FCP & 1 & 0,91 & $1.339,28$ & 0,14 \\
\hline IDATERRA/MS & 1 & 0,91 & 73,3177 & 0,01 \\
\hline INTERBA / FCP & 1 & 0,91 & 153,8043 & 0,02 \\
\hline INTERPI / INCRA & 5 & 4,55 & $20.497,61$ & 2,14 \\
\hline ITERMA & $23^{*}$ & 20,91 & $23.886,30$ & 2,49 \\
\hline ITERPA & $42 *$ & 38,18 & $454.346,29$ & 47,33 \\
\hline ITESP & 6 & 5,45 & $18.828,12 * *$ & 1,96 \\
\hline SEHAF/RJ & 1 & 0,91 & 287,9461 & 0,03 \\
\hline Subtotal & 80 & 72,73 & $518.740,38$ & 54,03 \\
\hline TOTAL & 110 & 100 & $960.010,81$ & 100 \\
\hline
\end{tabular}

As terras regularizadas totalizam uma área de 960.010,81ha, sendo o ano de maior área regularizada o de 2000. Como vimos, foi o ano em que a FCP foi responsável pela maioria dos títulos, porém uma regularização com grandes problemas, como já foi apontado (Gráfico 2). 


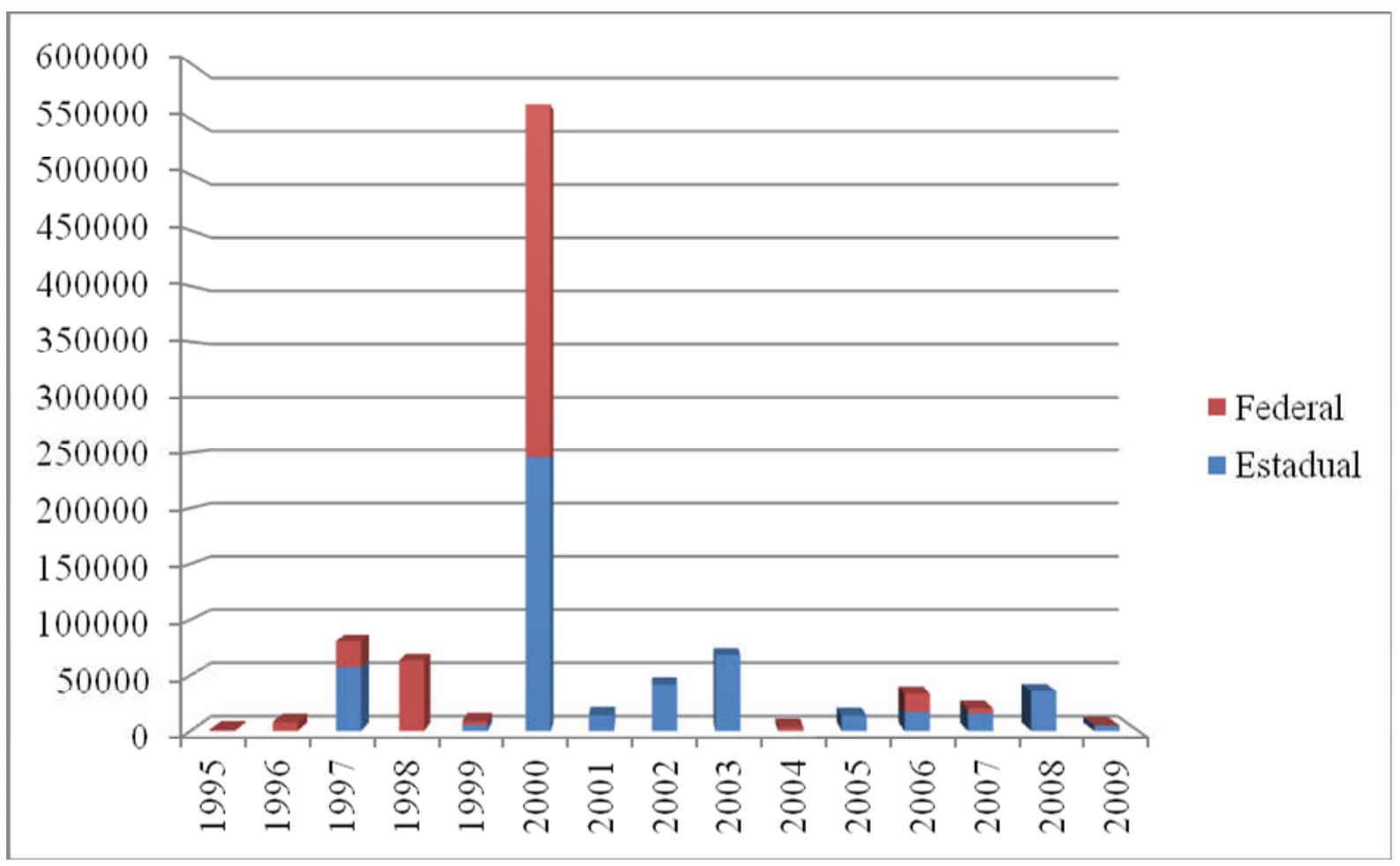

Gráfico 2: Área titulada (1995 - 2009).

Tanto o número de títulos emitidos por ano quanto a área regularizada são ínfimos em relação ao que é reivindicado pelas comunidades quilombolas que chegam a $3.000 \mathrm{em}$ todo o Brasil. De acordo com a CPI-SP (2010), a inoperância do INCRA se reflete no seu desempenho orçamentário. Desde 2004, o instituto não utiliza integralmente os recursos de seu orçamento destinados à titulação das terras quilombolas. Em 2004 utilizou apenas $10 \%$ do orçamento disponível; em 2005 somente 12\%; em 2006, 26\%; em 2007 apenas 23\%; em 2008, somente $10 \%$. Em 2009, o INCRA gastou apenas $12 \%$ do orçamento destinado ao pagamento de indenização aos ocupantes das terras que foram demarcadas e tituladas como território quilombola e ao reconhecimento, demarcação e titulação destes territórios, apesar do orçamento ter sido 35\% menor que o de 2008.

Para a CPI-SP (2010), não se pode justificar o pequeno número de titulações realizadas por falta de recursos e nem por motivo de processos paralisados em função de decisões judiciais, pois estes processos são poucos, apesar do aumento dos questionamentos na Justiça. De acordo com o monitoramento realizado por esta instituição, existem apenas 23 ações judiciais em curso que questionam procedimentos de regularização fundiária conduzidos pelo INCRA envolvendo 16 comunidades, um número pouco representativo diante dos mais de 900 processos em curso no INCRA. 
As regras para identificação e regularização dos territórios quilombolas instituídas pelo governo federal em 2008 agravaram ainda mais esse cenário, uma vez que tornaram os procedimentos ainda mais burocratizados, dispendiosos e demorados.

\subsubsection{A regularização dos territórios quilombolas no Pará}

No contexto das mobilizações do movimento negro para a elaboração das primeiras propostas que resultaram no artigo 68, iniciam-se no Pará, na década de 1980, os chamados mapeamentos de comunidades negras rurais efetivados primeiramente pelo Centro de Estudos e Defesa do Negro no Pará (CEDENPA) e depois pela UFPA(TRINDADE, 2005).

Conforme já dito no capítulo 1, nesse mesmo período, os moradores de comunidades negras do Baixo Amazonas paraense (Óbidos, Alenquer, Oriximiná e Santarém) reuniam-se nos Encontros de Raízes Negras, que ocorrem desde 1988 com o objetivo de debater questões referentes à realidade destas comunidades. Os dois primeiros Encontros de Raízes Negras incentivaram a criação da Associação das Comunidades Remanescentes de Quilombos do Município de Oriximiná (ARQMO) (TRINDADE, 2005). Estes encontros também possibilitaram a criação da Coordenação Regional das Comunidades Remanescentes de Quilombo do Baixo Amazonas (TRECCANI, 2006).

No Pará, as associações são representadas pela Coordenação das Associações das Comunidades Remanescentes de Quilombos do Pará (MALUNGU). A MALUNGU foi criada oficialmente em março de 2004, tendo como objetivos: promover a articulação entre as associações e as comunidades quilombolas no Pará, assim como apresentar e defender as suas reivindicações (MALUNGU, 2008a). Para isso, em 2008 foram criados cinco conselhos regionais: Salgado, Nordeste Paraense, Guajarina, Tocantina e Baixo Amazonas. Atualmente, das 90 associações existentes no estado, 82 são filiadas à Malungu. (MALUNGU, 2008a). Em março de 2008, em Belém, a MALUNGU realizou o II Encontro Estadual dos Quilombolas do Pará, cujo tema foi "Território e garantia dos direitos e da identidade étnico-racial das comunidades quilombolas do Pará”. O objetivo era criar um espaço de discussão para construir ações de fortalecimento em torno da defesa e garantia dos direitos, sobretudo, do território (MALUNGU, 2008b). 
Nacionalmente as associações são representadas pela Coordenação Nacional de Comunidades Rurais Quilombolas (CONAQ), criada em 1996 em Bom Jesus da Lapa, Bahia, durante reunião de avaliação do I Encontro Nacional de Quilombos. Da CONAQ participam representantes de comunidades de 22 estados da federação (CONAQ, 2009)

Foi com as primeiras mobilizações, na década de 1980, em torno da necessidade de reconhecimento das terras quilombolas, que a Constituição do Estado do Pará, de 1989, em seu artigo 322, também passou a garantir o que está disposto no artigo 68, mas com um diferencial: o artigo 322 estabeleceu o prazo de um ano, após a promulgação da Constituição do Pará, para que o Estado emitisse os títulos de propriedade ${ }^{30}$ (PARÁ, 2007a). A consagração deste direito na constituição do Pará não foi fruto dos quilombolas, mas do movimento negro urbano tendo como liderança o Centro de Estudos e Defesa do Negro no Pará (CEDENPA) (TRECCANI, 2006).

Em 1992 foi editado o decreto $n^{\circ}$ 663, de 20 de fevereiro, que dispõe sobre a titulação das terras ocupadas pelos remanescentes das comunidades dos quilombos no estado, porém foi apenas em 20 de novembro de 1995 que se realizou a primeira titulação de terras do Pará e do Brasil, em cumprimento ao artigo 68 do ADTC. O título foi emitido pelo INCRA à comunidade Boa Vista, situada no município de Oriximiná, com uma área de 1.125,03 ha, onde viviam 112 famílias (ACEVEDO MARIN; CASTRO, 1999). Esta titulação deu novo ânimo às organizações e foi um marco que consolidou o entendimento de que o artigo 68 é auto-aplicável e que a regularização desta categoria de terras deve ser coletiva, respeitando a forma como os quilombolas concebem e ocupam os seus territórios (CPI-SP, 2008).

Em 1997, pelo decreto ${ }^{\circ}$ 2.246, de 18 de julho, o Governo do Pará criou um Grupo de Trabalho formado por representantes de diversas secretarias, como o Instituto de Terras do Pará (ITERPA), a Federação dos Trabalhadores na Agricultura no Estado do Pará (FETAGRI), a ARQMO, o CEDENPA, a Comissão Pastoral da Terra (CPT), sob a coordenação da Secretaria de Estado de Ciência, Tecnologia e Meio Ambiente (SECTAM). O Grupo objetivava promover estudos e apresentar propostas de solução às questões relacionadas à regularização das terras em que moravam as comunidades negras rurais (ACEVEDO MARIN; CASTRO, 1999). Neste sentido, em 1998, em Belém, ocorreu o I Encontro de Comunidades Negras Rurais do Estado do Pará. O evento foi organizado pelo

\footnotetext{
30 Art. 322: "Aos remanescentes das comunidades dos quilombos que estejam ocupando suas terras, é reconhecida a propriedade definitiva, devendo o Estado emitir-lhes títulos respectivos no prazo de um ano, depois de promulgada esta Constituição" (destaque da autora) (CONSTITUIÇÃO DO ESTADO DO PARÁ, 2007, p.111).
} 
CEDENPA e pela SECTAM, com o apoio do Núcleo de Altos Estudos Amazônicos (NAEA/UFPA), do INCRA e do ITERPA. Participaram do encontro representantes de 63 comunidades oriundas de Ananindeua, Baixo Amazonas, Baixo Tocantins, região Bragantina e Baixo Acará (TRINDADE, 2005).

De acordo com Acevedo Marin e Castro (1999), havia naquele momento uma vaga idéia do número de comunidades quilombolas existentes no estado, mas independente deste número, o que vinha à tona eram os conflitos vivenciados pelas famílias em relação à posse da terra. Esboçou-se, nestes primeiros momentos, uma variedade de situações em relação à origem das comunidades no território, aos conflitos e às tensões em torno da terra e dos seus recursos.

Uma das metas deliberadas neste I Encontro de Comunidades Negras Rurais do Estado do Pará foi a continuidade do mapeamento iniciado pelo CEDENPA. Estes estudos ficaram sob responsabilidade da Universidade Federal do Pará (UFPA) por meio do NAEA. A pesquisa intitulou-se "Mapeamento de comunidades negras rurais no Pará: ocupação do território e uso de recursos, descendência e modo de vida" (SECTAM/UFPA/NAEA). Em sua primeira fase (1998/2000) foram localizadas 129 comunidades negras rurais. Em 2000, foram realizadas novas pesquisas por meio de convênios entre o Programa Raízes, do Governo do Estado do Pará e a UFPA (TRINDADE, 2005).

Ainda em 1998, foi promulgada a Lei Estadual n. ${ }^{\circ}$ 6.165, de 02 de dezembro, que dispôs sobre a legitimação das terras dos remanescentes das comunidades quilombolas. $\mathrm{O}$ decreto $\mathrm{n}^{\mathrm{o}}$ 3.572, de 22 de julho de 1999, vem regulamentar esta Lei, estabelecendo que compete ao Instituto de Terras do Pará (ITERPA) a execução dos procedimentos administrativos visando à identificação, demarcação e expedição dos títulos de propriedade de terras ocupadas pelos remanescentes. Também em 1999 foi emitida a Instrução Normativa ${ }^{\circ}$ 02, de 16 de novembro, visando regulamentar a atuação do ITERPA.

No Pará, como desdobramento da disposição do governo estadual já demonstrada na cooperação com o INCRA entre os anos 1995 e 1998, foi criado em 2000, pelo Decreto ${ }^{\circ}$ 4.054 de 12 de maio, o Programa Raízes, vinculado à Secretaria Especial de Defesa Social e à Secretaria Executiva de Justiça (SEJU). Este programa tinha como objetivo dinamizar as ações de regularização de domínio das áreas ocupadas por comunidades remanescentes de quilombos e indígenas e implementar medidas socioeconômicas, ambientais e culturais em apoio a essas comunidades. Além de contar com recursos próprios, o programa possuía cotas de recursos nas diversas secretarias destinadas ao trabalho com essas comunidades, conformando a política do governo estadual para o tema. O Programa Raízes era o canal por 
onde eram apresentadas ao governo estadual as demandas indígenas e quilombolas, assumindo a função fundamental de articulador das diferentes secretarias no sentido de responder a tais demandas (ARRUTI, 2003).

Em pouco mais de três anos de atividades, o Projeto Raízes contribuiu para a titulação de treze novos territórios quilombolas, que compreendem aproximadamente sessenta comunidades. Além disso, o Projeto implantou também um leque variado de iniciativas como: projetos produtivos, manejo de espécies florestais, aquisição ou construção de equipamentos de infra-estrutura como microssistemas de energia solar, de abastecimento de água, casas de farinha, aquisição de barcos, além das oficinas de valorização das manifestações culturais e esportivas locais (ARRUTI, 2003), como os Jogos Quilombolas que ocorriam de dois em dois anos (TRINDADE, 2005; PARÁ, 2008). O programa atuou também em parceria com a Federação dos Trabalhadores na Agricultura (FETAGRI) no sentido de viabilizar assessoria jurídica, e com a Universidade Federal do Pará no sentido de produzir estudos antropológicos em resposta aos questionamentos impostos por interesses conflitantes com os dos quilombolas (ARRUTI, 2003).

Em 2007, pela Lei $\mathrm{n}^{\circ} 6.941$, de 17 de janeiro, o governo estabeleceu políticas públicas específicas à população negra do Estado. Estas políticas, além de outros setores, contemplam o setor agrícola e fundiário objetivando a regularização fundiária e titulação de propriedades pertencentes aos remanescentes de quilombos. Também é criado o programa de apoio técnico e científico às atividades agropecuárias extrativistas, de produção e/ou comercialização, realizadas pelos quilombolas e por agricultores negros (PARÁ, 2007b).

Ainda em 2007, o Decreto ${ }^{\circ} 562$, de $1^{\circ}$ de novembro, criou um grupo de trabalho para a Consciência Negra e Promoção da Igualdade Racial, com o objetivo de elaborar o Plano Estadual de Políticas de Promoção da Igualdade Racial (PEPPIR) que pudesse prever o desenvolvimento de programas e de ações integradas entre os vários órgãos do estado e dos municípios, competindo à Secretaria de Estado de Justiça e Direitos Humanos (SEJUDH) a coordenação do grupo (PARÁ, 2007c) ${ }^{31}$.

O PEPPIR foi instituido pelo decreto $\mathrm{n}^{\circ} 1.404$, de 20 de novembro de 2008, e apresentado na II Conferência Estadual de Promoção da Igualdade Racial realizada no período de 14 a 16 de maio de 2009. Ele inclui princípios e diretrizes aprovadas na I Conferência de Promoção da Igualdade Racial realizada em 2005, e tem como uma de suas proposições o acesso à terra, habitação e infra-estrutura. A aprovação, controle, fiscalização,

\footnotetext{
${ }^{31}$ Este decreto teve uma alteração no art. $3^{\circ}$ por meio do Decreto n. ${ }^{\circ} 594$, de 16 de Novembro de 2007 . Alteraram o número de representantes do governo e das entidades e movimento negro.
} 
acompanhamento e avaliação do plano são de responsabilidade do Conselho Estadual de Políticas de Promoção da Igualdade Racial (CONEPPIR), criado em novembro de 2008 e integrante da estrutura da SEJUDH. As diretrizes contidas no PEPPIR norteiam o Programa Pará Quilombola (PPQ) da SEJUDH, que substituiu o Programa Raízes (PARÁ, 2008b). O fim do Programa Raízes foi visto pelas diversas lideranças quilombolas como um retrocesso nas políticas de apoio aos quilombolas, pois ele funcionava por meio de orçamentos previstos em cada secretaria do Estado. Com o fim do programa, não ficou estabelecido de onde sairia o dinheiro para o atendimento das demandas das comunidades (informação verbal) ${ }^{32}$.

O Programa Pará Quilombola (PPQ) que o substituiu tem como objetivo geral

estabelecer a formulação e a gestão pública da política de Estado voltada à população quilombola, bem como implementar convênios, projetos, ações e atividades voltadas para a promoção da igualdade racial, defesa e reparação dos direitos humanos e da cidadania das populações remanescentes de quilombos (PARÁ, 2008b, p. 67).

As ações do PPQ levam em consideração a missão e a competência de cada órgão governamental envolvido no processo, passando a ampliar e transformar as ações de seu antecessor, o Programa Raízes. A Coordenação Estadual de Políticas de Promoção da Igualdade Racial (CEPPIR), da SEJUDH, passou a propor e articular este programa desde 2008, buscando dinamizar sua implementação através do governo do estado e do governo federal, via Agenda Social Quilombola ${ }^{33}$. Para isso, foi criado o Comitê Gestor da Agenda Social Quilombola no Estado do Pará pelo Decreto Estadual n 1.240 , de 3 de setembro de 2008 (PARÁ, 2008b).

Que papel está reservado às comunidades quilombolas pelo governo do Pará? Em 2005, no Macrozoneamento Ecológico-Econômico ${ }^{34}$ do Estado do Pará, as terras destas comunidades estavam incluídas em uma das duas grandes zonas nas quais foi dividido o estado. A primeira zona, composta por $65 \%$ das terras, seria destinada às áreas especialmente protegidas: $28 \%$ das terras seriam para terras indígenas e terras de quilombos; $27 \%$ destinadas às unidades de conservação de uso sustentável, e 10\% destinadas às unidades de conservação de proteção integral. De acordo com o art. $6^{\circ}$ da lei que instituiu o macrozoneamento, as terras indígenas e as terras de quilombos seriam constituídas por aquelas já existentes e por aquelas que viessem a ser legalmente instituídas. A segunda zona seria composta por $35 \%$, no

\footnotetext{
32 José Galisa, presidente da MALUNGU, em entrevista concedida à autora em abril de 2010

${ }^{33}$ A Agenda é um programa de 2007, do governo federal, que prevê um conjunto de projetos e ações voltados para as localidades remanescentes de quilombos, a ser desenvolvido no período de 2008 a 2010.

${ }^{34}$ Lei $^{\circ}$ 6.745, de 6 de maio de 2005 .
} 
máximo, de terras que seriam destinadas para a consolidação e expansão de atividades produtivas, áreas de recuperação e áreas alteradas ${ }^{35}$ (BRASIL, 2005).

Estas áreas especialmente protegidas, onde estão as famílias quilombolas, devem constituir e, dentro do possível, contribuir para formação de corredores ecológicos, proteção de amostras de ecorregiões, ecossistemas e/ou centros relevantes de biodiversidade, populações de espécies ameaçadas de extinção e manutenção de serviços ecológicos (BRASIL, 2005).

Em dezembro de 2007, este macrozoneamento foi retomado dentro do Programa de Ordenamento Territorial do Estado do Pará, instituído pelo decreto no 692 de 5 de dezembro. Este ordenamento ocorreu através da realização do Macrozoneamento e do Zoneamento Ecológico Econômico da BR 163, da criação de dezenas de unidades de conservação, do reconhecimento do direito à terra aos indígenas e aos quilombolas, além da criação de assentamentos. Dentro deste Programa, podemos citar os projetos de arrecadação de terras devolutas, assentamentos estaduais, regularização fundiária por município, regularização fundiária urbana e assentamento quilombola (MARQUES; MALCHER, 2009).

À sua ação de ordenamento fundiário de âmbito municipal, o ITERPA denominou primeiramente de Varredura Fundiária. Contudo, o órgão acredita que as políticas públicas desenvolvidas atualmente vão além da simples entrega de títulos e que é preciso definir quem é que tem direito a ter acesso à terra. A partir desta compreensão é que a ação do órgão passou a denominar-se Regularização Territorial e está alicerçada em três pilares: o Fundiário, o Ambiental e o Produtivo (MARQUES; MALCHER, 2009).

Os requisitos para a regularização fundiária são a) Posse contínua; b) Cultura efetiva pelo prazo mínimo de um ano; c) Inexistência de oposição de terceiros; d) Não ser proprietário de outro imóvel rural; e) Não ter sido beneficiado com a concessão de áreas antes ou pelo programa de reforma agrária; f) Utilização adequadas dos recursos naturais (MARQUES; MALCHER, 2009). De acordo com Marques e Malcher (2009) a titulação se dará na forma de:

- Título Definitivo: doação (até 100 ha) ou venda direta da terra (de 100 a 2.500 ha); titulação de áreas urbanas (de áreas de patrimônio do município e retificação de áreas já tituladas pelo estado)

\footnotetext{
${ }^{35}$ De acordo com a lei no 11.952 de 2009, que é a conversão da MP 458, os estados da Amazônia Legal que não aprovarem o seu Zoneamento Ecológico-Econômico (ZEE) no prazo máximo de três anos, a contar da entrada em vigor desta lei, ficarão proibidos de celebrar novos convênios com a União, até que seja realizado o zoneamento.
} 
- Concessão de Direito Real de Uso: individual ou coletiva.

Esta concessão ocorre por meio da criação de projetos estaduais de assentamentos. Estes projetos foram criados pela Instrução Normativa ITERPA n ${ }^{\circ} 01$, de 9 de maio de 2007. Em 7 de dezembro do mesmo ano, por meio do decreto $\mathrm{n}^{\circ} 713$, foi instituído o Programa Estadual de Assentamentos e foram estabelecidos os critérios e normas para a criação, implantação e gestão dos assentamentos. Este programa é composto pelo Pró-Assentamento Estadual (PROA-PA) e pelos Projetos Estaduais de Assentamentos, inclusive para quilombolas.

O PROA-PA é constituído por ato administrativo de afetação e destinação de gleba de terra pública estadual para criação de assentamento. Depois deste procedimento, podem ser instalados os Projetos Estaduais de Assentamentos nas seguintes modalidades, de acordo com Marques e Malcher (2009):

- Projeto Estadual de Assentamento Sustentável (PEAS): são áreas trabalhadas em regime familiar, em que há o uso racional dos recursos naturais, cumprindo a função socioeconômica e ambiental da terra. Aos beneficiários é expedida concessão individual do lote. Eles, com a ajuda da assistência técnica, têm a obrigação de elaborar um Plano de Desenvolvimento. O assentamento deverá ser licenciado pela Secretaria Estadual de Meio Ambiente.

- Projeto Estadual de Assentamento Agroextrativista (PEAEX): Este projeto se destina às famílias que ocupem áreas dotadas de riquezas extrativas e pratiquem prioritariamente a exploração sustentável dos recursos naturais voltada para o seu próprio consumo e, complementarmente, dedicam-se à agricultura familiar de auto-consumo, a outras atividades de baixo impacto ambiental e à criação de animais de pequeno porte. Para os beneficiários é expedido um título de concessão coletivo em nome da associação. Neste caso, também está prevista a elaboração do Plano de Desenvolvimento e não será exigida a licença prévia, e sim apenas a licença de instalação e operação. A justificativa para o procedimento de concessão é que desta forma se evita aumento da concentração da terra e de inúmeras famílias sem terra em busca de novas áreas para ocupar, além de evitar a especulação fundiária da pequena propriedade e estimular as ações coletivas com o intuito de melhorar a produção e o preço da produção familiar. Essa concessão pode se tornar titulação definitiva somente com a regularização fundiária da média e da grande propriedade e com a política agrícola consolidada. 
- Território Estadual Quilombola (TEQ): destina-se às famílias quilombolas cujos territórios tenham sido reconhecidos de propriedade dos mesmos e visa garantir o etnodesenvolvimento destas comunidades. Nas áreas quilombolas a titulação é definitiva e coletiva, conforme estabelece a Constituição Federal (art.68 do ADCT) e a Estadual (art.322). Para isso, foi necessária a reorganização do ITERPA (Decreto $\mathrm{n}^{\circ}$ 063, de 14 de março de 2007) pela qual foi criada uma Coordenadoria de Projetos Especiais e uma Gerência de Comunidades de Quilombos que cuidam da política de apoio às comunidades quilombolas.

Os beneficiários dos projetos estaduais de assentamentos e dos territórios estaduais quilombolas seriam incluídos entre os candidatos a beneficiários da reforma agrária, tendo os mesmos benefícios de crédito, infra-estrutura e assessoria técnica, social e ambiental dos beneficiários dos projetos de assentamentos federais (BRASIL, 2007b). Para isso, o ITERPA objetiva solicitar o reconhecimento dos assentamentos pelo INCRA. O que o governo considera é que essas políticas complementam a do governo federal. O assentamento é pensado como um dos instrumentos da reforma agrária que busca compatibilizar as ações de regularização fundiária com as diretrizes e metas do Plano Nacional de Reforma Agrária (MARQUES; MALCHER, 2009).

O que o ITERPA chama de "assentamento" é uma forma de regularização fundiária que busca a fixação das famílias à terra. O termo é empregado justamente para que a pessoa tenha os mesmos benefícios oferecidos às demais famílias pela União. O governo do Pará tem uma política de ordenamento territorial em que a regularização fundiária passa a ser entendida como instrumento de ordenamento do espaço e de democratização do acesso à terra. Os objetivos são de desestimular a formação de grandes propriedades, diminuir a violência rural e o desrespeito aos direitos humanos, assegurar o direito de propriedade aos diferentes segmentos sociais, combater a apropriação indevida das terras públicas, diminuir o desmatamento e garantir a sustentabilidade ambiental (MARQUES; MALCHER, 2009).

\subsubsection{Quadro da política de regularização no Pará}

De 2004 a 2007, a FCP certificou que 81 comunidades negras rurais se autodefiniram remanescentes de quilombo no estado. Nos anos de 2008 e 2009 nenhuma certidão foi 
expedida. Talvez esta situação se explique pelo fato de que foi em 2007 que a FCP editou nova regulamentação exigindo um número maior de documentação das comunidades ${ }^{36}$. Tudo isto dificultou o cadastro na fundação.

Há indicações da existência de comunidades quilombolas em 49 dos 144 municípios que formam o estado do Pará. Todavia, somente em 19 municípios é que existem as 107 comunidades já tituladas como território quilombola, totalizando 51 títulos e 47 territórios em uma área total de 571.210,47 ha, onde residem 4.969 famílias. Considerando-se o restante do Brasil, o Pará possui 46,36\% dos títulos expedidos, 46,53\% dos territórios criados, abrangendo $60,45 \%$ das comunidades beneficiadas, com 44,20\% do número de famílias e atingindo $59,51 \%$ de área titulada.

Estes 51 títulos dividem-se em títulos da FCP, do INCRA e do ITERPA. Grande destaque é dado à atuação do ITERPA, que desde 1999 tem a competência para a regularização das terras que estão sob jurisdição do estado do Pará (Tabela 2).

Tabela 2 - Títulos expedidos por órgão (1995 - 2009)

\begin{tabular}{lcccc}
\hline \multicolumn{1}{c}{ Órgão } & $\mathbf{N}^{\mathbf{0}}$ de Títulos & Comunidades & Famílias & Área \\
\hline FCP & 1 & 6 & 445 & $17.189,69$ \\
INCRA & 8 & 22 & 621 & $99.674,49$ \\
ITERPA & $42 *$ & 79 & 3.903 & $454.346,29$ \\
TOTAL & $\mathbf{5 1}$ & $\mathbf{1 0 7}$ & $\mathbf{4 . 9 6 9}$ & $\mathbf{5 7 1 . 2 1 0 , 4 7}$ \\
\hline
\end{tabular}

* 14 desses títulos foram expedidos pelo ITERPA em parceria (técnica e/ou financeira) com $o$ INCRA/MDA.

Fonte: INCRA, 06/01/2010; ITERPA, 30/11/2009.

Organização: Rosiete Santana, 2009.

Estes títulos foram expedidos ao longo de 21 anos após o artigo 68, porém as titulações só iniciaram em 1995. Neste período, dois anos se destacaram pelo número de títulos expedidos: os anos de 2002 e 2008 (Gráfico 3).

\footnotetext{
${ }^{36}$ Portaria FCP $n^{\circ}$ 98, que exigia os seguintes documentos: ata de assembléia onde é aprovado o reconhecimento; dados, documentos ou informações que atestem a história comum do grupo ou suas manifestações culturais e um relato sintético da trajetória comum do grupo.
} 


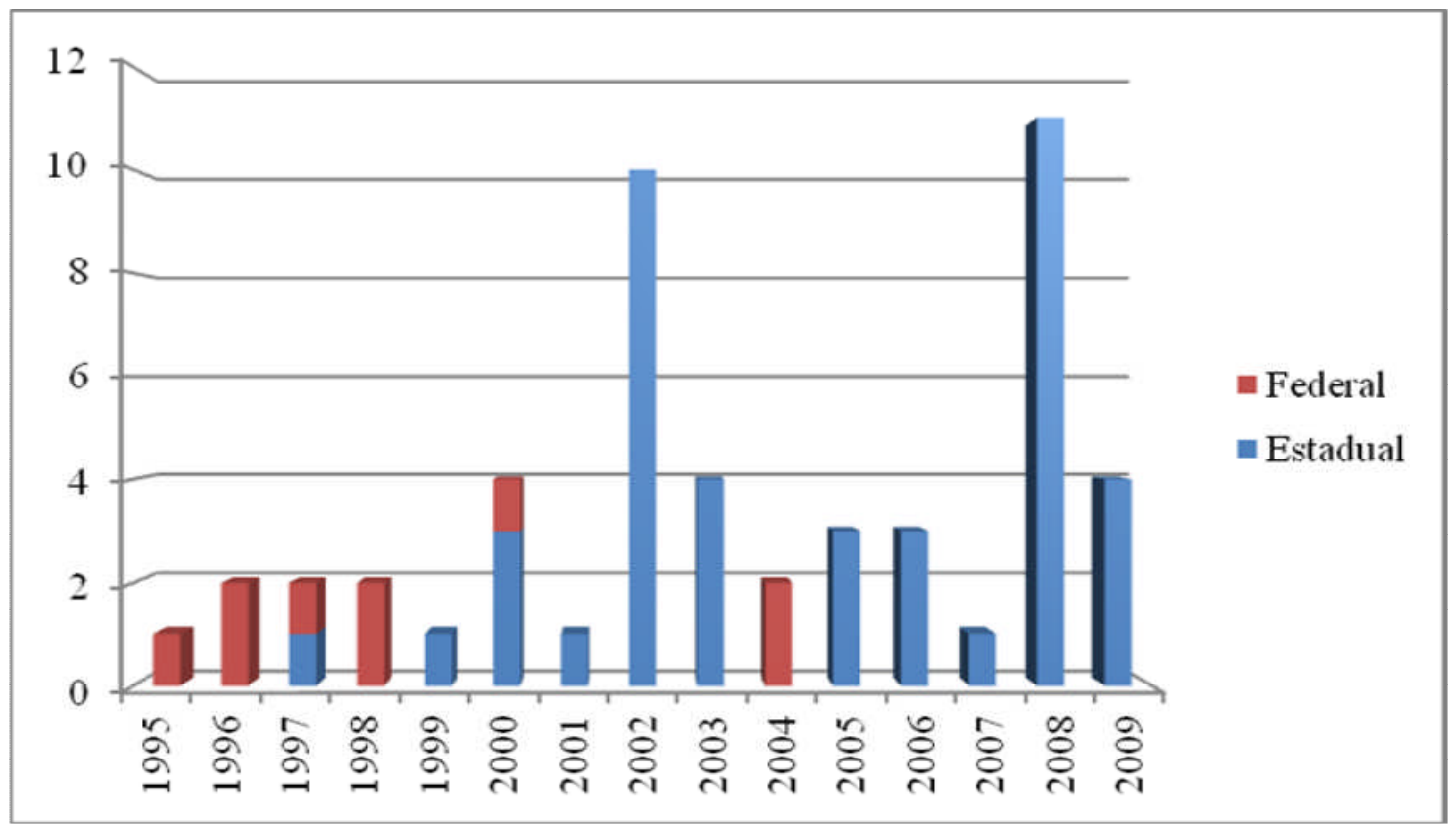

Gráfico 3: Número de titulações no Pará por ano e por órgão (1995 - 2009).

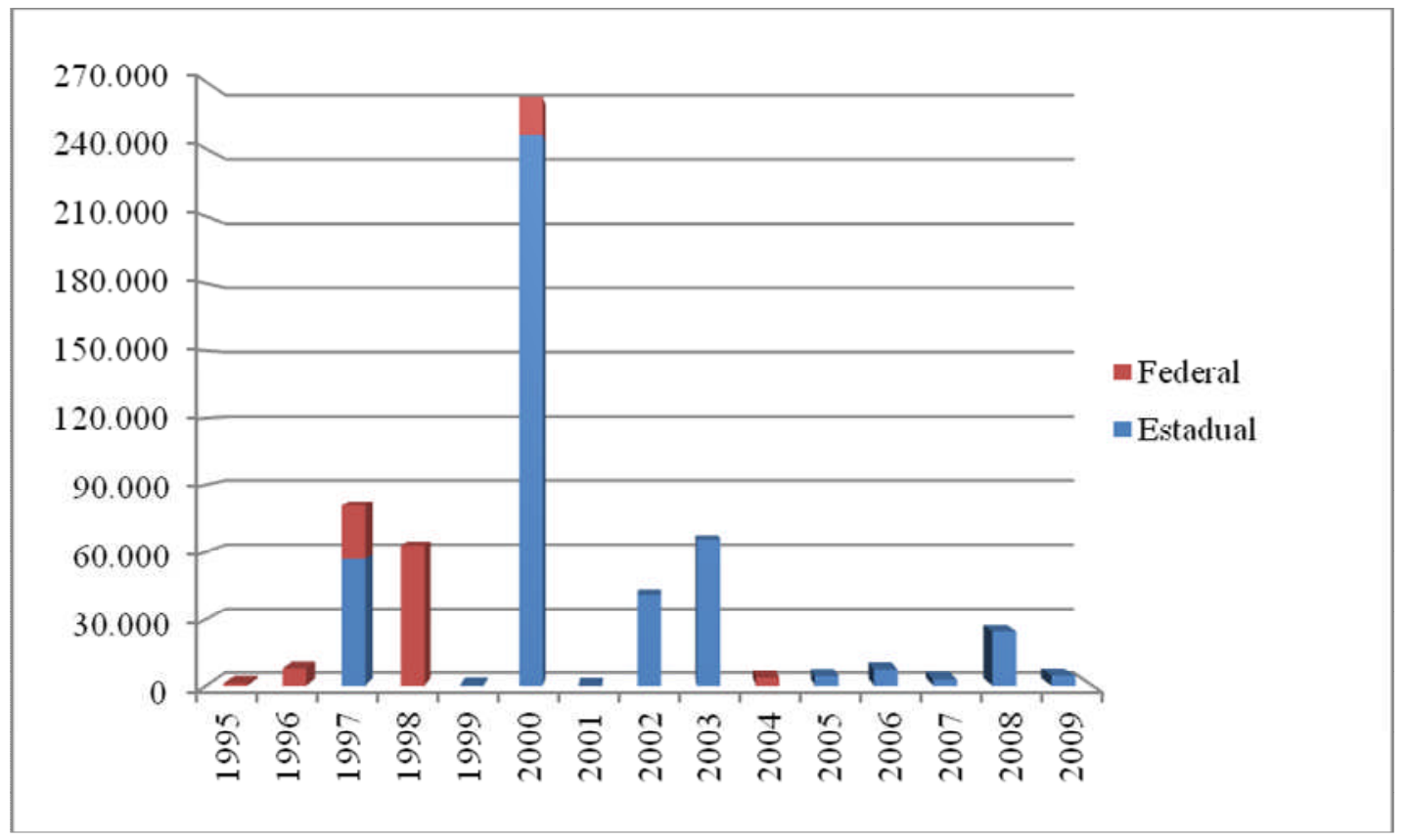

Gráfico 4: Área titulada no Pará por ano e por órgão (1995 - 2009).

De acordo com a MALUNGU, muitos dos territórios já titulados ainda estão ocupados por pessoas que se dizem donas ou que já foram indenizadas para desocuparem as terras mas que ali ainda permanecem, ou seja, muitos dos processos de titulação não foram acompanhados do processo de desintrusão do território (MALUNGU, 2008b). Cerca de 80\% dos territórios criados no estado estão localizados nas tradicionais regiões indicadas pela 
historiografia como áreas de concentração tanto dos engenhos quanto de quilombos no século XIX: no entorno de Belém (rios Tocantins, Moju, Acará e nos limites com o Maranhão).

Um território quilombola, quando reconhecido pelo Estado, pode ser composto por uma ou mais comunidades, e ultrapassar ou não os limites municipais. É o caso, por exemplo, do Território Bailique, composto por quatro comunidades, titulado em 2002 pelo ITERPA e localizado nos município de Oeiras do Pará e Baião, e do Território Igarapé Preto, composto por 12 comunidades, titulado também em 2002 pelo ITERPA, localizado nos municípios de Oeiras do Pará, Baião, Mocajuba e Bagre. De acordo com Andrade (2007), o fato de várias comunidades possuírem um único título ocorre quando todas elas utilizam uma mesma área. Neste caso, faz-se um acordo e se pede uma única titulação. Ao contrário, há casos em que um território pode possuir dois títulos de áreas que se somam. É o caso do Território de Erepecuru, composto por sete comunidades localizadas nos municípios de Oriximiná e Óbidos. Este território possui um título do INCRA (expedido em 1998) e outro do ITERPA (em 2000 em parceria com o INCRA). Isto ocorre pelo fato das terras estarem sob diferentes jurisdições.

Sobre a definição dos limites de um território, é preciso a participação de toda(s) a comunidade(s), sendo que o território deve incluir as áreas das casas e do roçado, dos pastos, de coleta e de caça, de cultos, de lazer e de sítios que contenham reminiscências históricas dos antigos quilombos, enfim, toda área utilizada pela(s) comunidade(s). O decreto federal 4.887/2003 reconhece que o território deve ser titulado de acordo com a definição da comunidade (ANDRADE, 2007).

De acordo com Acevedo Marin e Castro (2005), no Pará o reconhecimento de um território em comum entre os membros das comunidades lhes permite apreender $o$ processo de territorialização como sínte se da apreensão do universo social e cultural do grupo. A territorialização concretiza-se em práticas cotidianas, na busca de estratégias de vida e de trabalho, na execução de ações que são criadoras da existência material e social.

Para Acevedo Marin e Castro (2005) a dimensão territorial se expressa nas narrativas sobre a experiência cotidiana. Os lugares estão referidos aos marcos naturais, sendo os rios e igarapés, a várzea ou igapó, fundamentais na demarcação dos espaços que são estruturados sob um subsistema de regras onde estão "prescritas" as permissões e as interdições das práticas grupais.

Atualmente, estudos em comunidades negras rurais na Amazônia têm demonstrado que o passado de escravidão na região foi marcado pela resistência e pela organização de um campesinato negro que possui uma forte identificação com o território. Treccani (2006) 
considera que a regularização dos territórios quilombolas tem um caráter peculiar. É um reconhecimento muito diferente dos processos de regularização fundiária e dos assentamentos de reforma agrária. Trata-se de uma forma étnica de acesso à terra que engloba elementos de direito agrário, direito étnico e ambiental.

(...) [A] incorporação dos conceitos étnicos e culturais na demarcação das terras e o uso compartilhado de recursos que se dá conforme normas internas estabelecidas pela comunidade, criam uma nova realidade jurídica, muito diferente das normas contidas no Código Civil que privilegia as relações de propriedade de caráter particular (TRECCANI, 2006, p. 157).

Neste processo de regularização, muita paciência, luta e trabalho são exigidos destas comunidades. Às vezes o conflito gerado na luta tem dimensões nunca imaginadas por elas. Acevedo Marin e Castro (1998) mostram bem isso ao relatar os conflitos pelos quais passam as comunidades no Trombetas. Conflitos que envolvem os quilombolas e as empresas mineradoras, do setor elétrico e órgãos públicos de preservação ambiental que geram a desestruturação da vida social e econômica destes grupos. De acordo com as autoras, o

[... Estado avalizou os financiamentos e a acumulação privada nafronteira, contribuindo para o cerco às terras de índios e camponeses[...]. O exame do empreendimento de bauxita da Mineração Rio Nore [...] elucida de forma particular a montagem de estratégias de ocupação e domínio de um território conformado na cumplicidade entre Estado e empresa (ACEVEDO MARIN; CASTRO, 1998. p. 207).

A garantia do território para os quilombolas que não o têm e a manutenção dos territórios dos que já o possuem, para a MALUNGU, é um dos grandes desafios no estado. No II Encontro Estadual dos Quilombolas do Pará, em 2008, foram destacados os problemas da falta de titulação; da falta de documentação necessária para dar início ao processo de regularização; da falta de ação dos órgãos fundiários e ambientais, além da morosidade dos mesmos, e da falta de antropólogos para atuar nos órgãos. Também foi destacada a incompetência de alguns servidores, a resistência em relação ao processo de desapropriação e o fato de que muitos quilombolas acabam cedendo às pressões de fazendeiros, madeireiros e outros, o que resulta na perda do território (MALUNGU, 2008b). Neste encontro, as principais exigências feitas aos representantes dos órgãos fundiários e ambientais presentes foram: resposta sobre a situação de morosidade dos processos e da desintrusão dos territórios; superação da falta de acesso às informações sobre os processos em andamento e do excesso de burocracia; eliminação do descaso com que os quilombolas são tratados pelos funcionários; punição e indenização da perda dos documentos protocolados; criação de um sistema de informação e comunicação entre os órgãos para superar o desencontro de 
informação, o que gera um desgaste e onera os quilombolas com as idas desnecessárias aos órgãos (MALUNGU, 2008b).

Para tentar agilizar os processos de regularização, uma das iniciativas da MALUNGU foi a criação de um grupo de trabalho formado pelas seguintes instituições: ITERPA, INCRA, AGU, CEDENPA e UNAMAZ. A prioridade na ação do grupo é a ilha do Marajó devido aos graves conflitos lá existentes (informação verbal) ${ }^{37}$.

Além da questão da regularização, um outro desafio apontado pela MALUNGU é a assistência técnica e a organização da produção nas comunidades. Este problema se agrava quando não há um entendimento, entre os técnicos e as famílias, sobre que trabalho desenvolver; quando o prazo de envio de projetos para o governo (federal ou estadual) é curto, e porque os quilombolas não têm a formação necessária para a elaboração destes projetos.

\subsubsection{Campo Verde, um território quilombola}

Campo Verde é uma das muitas comunidades negras rurais existentes no estado do Pará que buscam o reconhecimento enquanto quilombola. Para as famílias de Campo Verde, considerar a comunidade como remanescentes de quilombo foi uma novidade. De acordo com uma das lideranças ${ }^{38}$, esta notícia chegou por meio dos membros da CPT/Guajarina, Antonina e Padre Sérgio, que realizaram uma reunião $0^{39}$ na comunidade para esclarecer às famílias sobre a possibilidade de se autodefinirem quilombolas e obterem assim a titulação coletiva (e definitiva) das terras. Um esclarecimento dado às famílias foi que a titulação individual seria perigosa porque facilitaria a venda de terra e, com isso, a entrada de pessoas estranhas, principalmente de fazendeiros.

Além da preocupação com o fazendeiro, outros dois fatores foram levados em consideração para a aceitação da autodefinição e da titulação coletiva: a ARQUINEC acreditava que o procedimento para a regularização das terras seria mais fácil, menos burocrático e que teriam mais chances de aprovação de projetos de desenvolvimento econômico para as famílias. Observa-se que, muito mais importante que a autodefinição como

\footnotetext{
${ }^{37}$ José Galisa, presidente da MALUNGU, em entrevista concedida à autora em abril de 2010.

${ }^{38}$ Miguel Modesto da Silva, em entrevista concedida à autora em outubro de 2008.

${ }^{39}$ Não consegui a data da reunião.
} 
quilombola, estava a preocupação com a urgência de se garantir a terra para a permanência das famílias que na sua grande maioria é posseira. Das 42 famílias cadastradas pelo INCRA em 2005, existiam somente três com título definitivo e quatro com licença de ocupação. Todos estes documentos foram dados pelo INCRA.

Segundo Castro (2003), em 1978 foi iniciado pelo INCRA o Projeto Fundiário Paragominas, que se constituía numa proposta de regularização fundiária da Comissão Especial de Discriminação de Terras Devolutas da União, abrangendo uma área de aproximadamente 103.750 ha, denominada Gleba Bujaru (com mais de 1200 lotes recortados). Essa área estava localizada em partes dos municípios de São Domingos do Capim e de Bujaru (ainda não existia Concórdia do Pará). O projeto foi concluído em 1982, quando foram entregues para muitas famílias títulos de propriedade, mas de domínio precário, majoritariamente de até 100 ha, com grande concentração de lotes com menos de 25 ha.

Para que as terras das famílias de Campo Verde tivessem a titulação coletiva foi preciso que as famílias cancelassem os documentos que já possuíam em prol do título coletivo, o que foi aceito e feito por todos aqueles que os possuíam. Sem dificuldades para que as famílias aceitassem a titulação coletiva, em 2001, a CPT/Guajarina fez o pedido de regularização das terras ao ITERPA. Neste mesmo ano, as famílias foram informadas de que as terras que ocupavam pertenciam à União e que caberia à FCP a competência da sua regularização (Decreto Federal no 3.912 de setembro de 2001).

Em 14 de abril de 2004 a CPT/Guajarina e a ARQUINEC realizaram uma reunião para a autodefinição das famílias como quilombolas e para formalizar o pedido de titulação coletiva junto ao INCRA $^{40}$ (MALCHER, 2009). Em 2005 foi encaminhada à FCP a declaração de autodefinição da comunidade, e em 13 de novembro de 2006 esta fundação registrava Campo Verde no Livro de Cadastro Geral no 07 - Registro no 787- Fl. 98, como comunidade de remanescentes de quilombo e emitia a certidão de autodefinição (BRASIL, 2006).

Mesmo antes da emissão da certidão da FCP, em agosto de 2005, uma comissão técnica do INCRA esteve na comunidade com o objetivo de fazer o levantamento ocupacional, cartorial e topográfico para a elaboração do Relatório Técnico de Identificação e

\footnotetext{
${ }^{40}$ Processo Administrativo INCRA/SR-01/PA/nº 54100.001570/2005-31(DOU, 2009).
} 
Delimitação (RTID), que ficou pronto no mesmo ano ${ }^{41}$ (INCRA, 2005). Em 2007, o Comitê de Decisão Regional (CDR) do INCRA no Pará aprovou o RTID ${ }^{42}$. (DOU, 2009).

Foi somente em 2008, por meio da Portaria n 391 , de 02 de novembro, que o governo federal reconheceu e declarou como território quilombola a comunidade, por meio da ARQUINEC. Com esta mesma portaria foram reconhecidas também as comunidades Santo Antônio, Dona e Ipanema, abrangendo uma área de 5.802,1703 ha ${ }^{43}$. Esta portaria, porém, foi publicada somente em 03 de abril de 2009 (IOEPA, 2009) e o título definitivo foi expedido em 25 de agosto de 2010 (INCRA, 2010) e entregue no dia 08 de setembro de 2010.

Desde o primeiro momento das discussões sobre a aceitação ou não da autodefinição e da titulação coletiva, em 2001, até a formalização do pedido de regularização em 2004, passaram-se três anos. Da formalização do pedido à publicação da portaria de reconhecimento, passaram-se quatro anos e quase sete meses. Da data da portaria à entrega do título, foram um ano e um pouco mais de 10 meses, ou seja, se passaram quase dez anos para que, enfim, as famílias de Campo Verde pudessem comemorar o que consideram uma vitória: a titulação definitiva de suas terras.

Esse foi um período, como já dito, marcado nacionalmente pelo decreto federal $\mathrm{n}^{\circ}$ 3.912 de 2001, que retirou a competência de titulação do INCRA passando-a à FCP, que não tinha recursos humanos e nem financeiros para o trabalho. Esse decreto, vale recordar, determinou que somente fossem tituladas as terras ocupadas por quilombos em 1888 e que estavam ocupadas por remanescentes das comunidades quilombolas em 10 de outubro de 1988, o que restringiu os direitos que são conferidos pelo art. 68 às comunidades. Também foi marcado pela retirada da atribuição de titulação da FCP, dada ao INCRA, em 2003, pelo Decreto $n^{\circ}$ 4.887; pela Instrução Normativa n. ${ }^{\circ} 49$, de 29 de setembro de 2008, que regulamentou procedimentos para a titulação das terras, tornando-os mais complexos, e por intensas ofensivas ao Decreto n. ${ }^{\circ}$ 4.887, realizadas por deputados dos Democratas (DEM) e do Partido do Movimento Democrático Brasileiro (PMDB), de Santa Catarina, conforme tratado no capítulo 1 deste trabalho.

O resultado de todo o jogo de forças, entre quem defende a proposta de regularização das terras das famílias quilombolas e quem pretende restringir estes direitos, é a demora do

\footnotetext{
${ }^{41}$ Comissão instituída pela Ordem de Serviço/INCRA/SR-01/G/n ${ }^{\circ}$ 187/2005, de 31 de agosto de 2005. (DOU, 2009).

${ }^{42}$ Ata no 011/2007, da Reunião do Comitê de Decisão Regional (CDR) (DOU, 2009).

${ }^{43} \mathrm{Na}$ relação de Títulos expedidos às comunidades quilombolas do INCRA, de 26 de agosto de 2010 a área que aparece é de 5.981,3412 (INCRA, 2010).
} 
processo de regularização. Demora que não era esperada pelas famílias e que terminou por esvaziar o discurso de que se as comunidades de Concórdia do Pará optassem pela titulação coletiva, o processo de regularizar suas terras seria mais rápido. Também possibilitou que outras lideranças de outras comunidades, que defendiam a regularização das terras através de projetos de assentamentos, pudessem usar esta situação como exemplo de que os recursos como estrada, energia, abastecimento de água, etc. viriam mais rapidamente para as famílias que optassem pela regularização através de assentamento e não como remanescentes de quilombos, colocando em dúvida a questão da efetiva concretização do processo de regularização para essas últimas.

A proposta de Campo Verde se transformar em assentamento também surgiu como opção de regularização e foi trazida pelo STR de Concórdia do Pará. Para uma das lideranças de Campo Verde, que é também o delegado sindical, um assentamento só deveria ser feito em terras de fazenda, onde não existisse mata. Ela não concorda em ter que desmatar as áreas de mata que ainda existem em grande parte das terras da comunidade para fazer assentamento. Outra situação colocada por esta liderança é o receio de que com o projeto de assentamento, algumas de suas quatro posses (em média 25 ha cada) pudessem ser tomadas pelo INCRA e ser entregue a outras pessoas sem-terra e de fora da comunidade. Ela possui sete filhos e quer garantir a terra para que no futuro seus filhos possam viver dela, ou seja, possam continuar enquanto camponeses. Para ela, este é um dos motivos para aceitar a titulação coletiva, pois com ela as posses para a família estariam asseguradas.

O medo da perda da terra é uma constante na fala das famílias, isto porque Concórdia do Pará vem sofrendo profundas mudanças nas últimas três décadas e o aumento da pressão sobre as terras faz parte desse processo. Primeiramente, o que se observou nas décadas de 1980 e 1990 foi a expansão da pecuária aliada à atividade madeireira e, conseqüentemente, o aumento do desmatamento. Neste novo século vemos a pecuária cedendo espaço para a dendeicultura, o que também vem gerando novos desmatamentos, a redução das ocupações camponesas e até mesmo a saída de famílias de suas terras. Isto é bem visível desde 2007 com o crescente incentivo por parte do governo federal, estadual e municipal para a implantação da dendeicultura no município, atividade vista pelo poder público como um vetor de desenvolvimento para o município e região do entorno, trazendo benefícios para todos os segmentos sociais ali presentes.

Todas estas mudanças estão relacionadas com a abertura de rodovias como a PA 140, que liga Concórdia do Pará a Belém e a PA 252 que liga o município à rodovia Belém Brasília na década de 1970. Além da abertura destas rodovias, em 2002 foi inaugurada a Alça 
Viária, um complexo viário que visa a interligação da região metropolitana de Belém com o porto de Vila do Conde e a rodovia PA 150 através da pavimentação de estradas e da construção de pontes para a transposição dos rios Guamá, Acará e Moju. Com este complexo ficaram interligados todos os municípios das duas margens destes rios. Isto permite uma maior incorporação das terras de Concórdia do Pará ao processo de expansão da economia de mercado, a especulação imobiliária e a conseqüente pressão sobre as terras camponesas, gerando impactos sobre as formas de ocupação da terra.

É neste contexto que garantir o acesso e a permanência na terra ainda é o grande desafio de inúmeras famílias, mesmo as de Campo Verde que receberam recentemente o seu título, e que também têm como desafio a gestão coletiva da terra. A despeito das grandes dificuldades impostas pelo Estado, são também inúmeras as iniciativas de superar os entraves por parte dos camponeses, que se autodefinirem quilombolas, o que renova as esperanças de permanência na terra.

\subsection{Jutaí-Mirim: Território Quilombola ou Projeto de Assentamento?}

\subsubsection{Território em disputa}

Apesar de a comunidade Jutaí-Mirim ter se tornado um assentamento em 2006, a primeira proposta de regularização fundiária apresentada às famílias foi a de criação de um território quilombola. Em abril de 2004 foi realizada uma assembléia para a autodefinição das famílias como remanescentes de quilombo (MALCHER, 2009), mas esta não chegou a ser certificada pela FCP. Segundo uma das lideranças de Jutaí-Mirim, diversas famílias chegaram a se associar à ARQUINEC e a participar das reuniões que ela realizava, e uma grande maioria das famílias chegou inclusive a receber cestas básicas do governo federal que chegavam por meio da associação.

Esta situação começou a se modificar quando um dos moradores, ao saber em uma das reuniões com a ARQUINEC que a titulação seria coletiva, questionou sobre a impossibilidade de venda da terra a terceiros caso necessitasse ou quisesse. A partir desta discordância com a associação, este morador, juntamente com um fazendeiro que possui uma fazenda vizinha à 
comunidade, iniciou inúmeras reuniões com as famílias de Jutaí-Mirim com o intuito de divulgar a proposta de regularização das terras por meio da criação de Projeto de Assentamento (PA) ${ }^{44}$.

De acordo com este morador, a criação de um assentamento traria mais rapidamente melhorias para as famílias do que um território quilombola, pois não conhecia nenhum território quilombola que tivesse recebido o que um projeto de assentamento recebia e com esse argumento buscou convencer as famílias a não aceitarem a proposta da ARQUINEC, no que contou também com o apoio do presidente do STR de Concórdia do Pará, cuja posição era de defesa do assentamento ao invés do reconhecimento como remanescente de quilombos.

Segundo um dos diretores do STR, o sindicato defende a criação de assentamentos e colabora no que pode para sua instalação, mas a queixa que faz é a de que, depois de instalados, são pouquíssimos os assentados que se associam ao sindicato, não havendo assim, para este, um retorno financeiro.

Em agosto de 2005, representantes de Jutaí-Mirim estiveram participando de uma reunião na comunidade Santo Antônio, onde estavam presentes representantes do INCRA, MPA, Comitê Popular Resistência Amazônica, STR e de outras comunidades quilombolas. Nesta ocasião, foram debatidas questões como o que seria uma comunidade quilombola, quais os procedimentos para a titulação e qual o objetivo da ARQUINEC. Também foi esclarecido, a pedido do STR, que quem teria direito a receber as cestas básicas e outros benefícios eram somente os que se autodefinissem quilombolas (ARQUINEC, 2005).

No mês seguinte, uma carta foi encaminhada ao INCRA pelos "residentes nas comunidades de Jutaí, Jutaí-Mirim e Ipanema", denunciando que um grupo, do qual participava Antonina, estava realizando reuniões para convencer as famílias a se autodefinirem quilombolas. Também denunciava que este grupo prometia inúmeros benefícios e pedia que as pessoas assinassem um termo de adesão (possivelmente seria a declaração de autodefinição como quilombola). O convencimento das famílias ocorria por meio da promessa de que somente receberiam cesta básica do governo federal as famílias que assinassem o termo e que, caso não assinassem, seriam remanejadas para outras áreas. Este fato foi considerado pelos "residentes” como uma intimidação (CARTA [...], 2005).

\footnotetext{
${ }^{44}$ Alguns moradores, ao serem questionados sobre o porquê de um fazendeiro estar fazendo a campanha em prol do assentamento, acreditam que talvez fosse pelo interesse deste senhor de ser presidente da associação que precisaria ser fundada para poder receber os recursos do assentamento. Como isto não ocorreu, ele se afastou, não indo mais à comunidade.
} 
Para as famílias "residentes nas comunidades de Jutaí, Jutaí-Mirim e Ipanema” a titulação de forma coletiva era polêmica e vista como algo que estava trazendo tumulto para as comunidades e pânico para as famílias que tinham medo de perder suas terras caso não aceitassem essa forma de titulação. Diante desta situação, segundo a carta, as famílias chamaram o INCRA de Tomé-Açu, que esclareceu o que era um território quilombola e um projeto de assentamento e como os recursos chegariam a cada projeto (CARTA [...], 2005). $\mathrm{Na}$ carta também pediam um levantamento das terras e que o INCRA respeitasse o direito das famílias permanecerem nelas; que a ação do órgão fosse imparcial e que o mesmo não usasse de ameaças para conseguir adesões a qualquer um dos projetos. Outro pedido feito ao órgão era que as direções das comunidades (presidente/coordenador, secretário e tesoureiro) fossem ouvidas. O problema que ocorria, segundo a carta, é que representantes de movimento social (citam o MPA) chegavam ao INCRA se dizendo representantes das comunidades, ignorando a direção já existente em cada uma (CARTA [...], 2005).

O debate em torno da proposta de regularização colocou em lados opostos a ARQUINEC e o STR, assim como várias famílias na comunidade, já que não se conseguia um consenso em torno de nenhuma das propostas. Segundo um dos moradores, que preferia a criação do território quilombola, o assentamento somente foi aceito por sua família porque a maioria das famílias da comunidade estava aceitando esta proposta de regularização, e a dele não queria ficar isolada. Segundo uma das lideranças, o discurso usado para que as famílias aceitassem o assentamento era de que seria difícil conseguir recursos como quilombolas, e que o título coletivo não serviria para aposentar quem precisasse.

Por meio da mobilização feita em prol do assentamento, este então foi criado. Isto acirrou ainda mais os conflitos entre ARQUINEC e STR, deixando algumas famílias entre a associação e o sindicato, entre o projeto quilombola e o projeto de assentamento. Para tentar resolver os conflitos, foi realizada uma reunião em dezembro de 2007 entre STR e ARQUINEC, na sede do STR. Um dos motivos era porque existiam famílias na comunidade que não queriam o projeto de assentamento (que já estava criado). Uma das famílias propôs uma terceira alternativa: a demarcação das terras e entrega dos títulos individuais, ou seja, nem território quilombola, nem assentamento (ATA [...], 2007).

O outro motivo da reunião foi a busca de um acordo entre associação e sindicato em torno da área de atuação de cada um. A ARQUINEC propôs ao STR que o mesmo parasse de incentivar a criação de assentamentos nas áreas consideradas quilombolas. Se o STR respeitasse esta área, a ARQUINEC evitaria o confronto com o mesmo. Ficou acordado que a ARQUINEC entregaria ao STR a relação das comunidades que ela identificava como 
quilombolas (ATA [...], 2007). Desde 2006, a ARQUINEC já havia conseguido a certidão da FCP de nove comunidades, sendo que neste mesmo ano eram $14^{45}$ as que se autodefiniam como quilombolas.

O que observamos aqui é a disputa pelo território camponês por entidades que defendem propostas diferentes de regularização. No meio desta disputa estavam as próprias famílias buscando compreender as propostas das entidades para decidirem o que fazer. Não são meras propostas diferentes, mas sim concepções diferenciadas de propriedade e de que elementos levar em consideração no momento de reivindicar a titulação das terras. Como Treccani (2006) esclarece, a regularização das terras como remanescentes de quilombos é uma forma étnica de acesso à terra que engloba elementos de direito agrário, como direito étnico e ambiental. De acordo com Almeida (2002), os sindicatos, em inúmeros contextos, se revelaram limitados para contemplar as expectativas de direito das chamadas "novas etnias",46 ou seja, de grupos que se investem em uma identidade cultural com um objetivo de fazer valer seus direitos.

Cabe aqui ressaltar que as lideranças da ARQUINEC e do STR não são da comunidade. E nela, o sindicato não tinha nenhuma delegacia sindical que pudesse estreitar os laços entre o sindicato e as famílias. Na fala de um morador contida na carta, nota-se a preocupação em fazer com que pessoas da própria comunidade assumam a responsabilidade no encaminhamento dos procedimentos necessários para a regularização e não que o mesmo seja feito por pessoas de fora. É por isso que na formação da comissão responsável para dar início ao processo de criação do assentamento, não aceitaram pessoas que não morassem em Jutaí-Mirim. Foi o caso do fazendeiro que estava fazendo a campanha em prol do assentamento. Os moradores acreditam que ele estivesse interessado em ser presidente da associação. Como isto não ocorreu, ele não foi mais à comunidade.

Uma situação a se destacar é a desconfiança em relação ao próprio Estado, à sua ação ordenadora do espaço agrário. Este mesmo Estado esteve ausente por anos e que agora apresenta seus programas, fazendo com que as famílias busquem novas formas de organizar seu território, de se organizar socialmente.

\footnotetext{
${ }^{45}$ Além das já certificadas tínhamos Curuperezinho, Jutaí Grande, São Raimundo, Km 51 e Pernambuco.

${ }^{46}$ Aspas do autor.
} 


\subsubsection{O assentamento Jutaí e Ipanema}

O termo assentamento apareceu pela primeira vez, no vocabulário jurídico e sociológico, no contexto da reforma agrária venezuelana, em 1960. No Brasil, o termo surgiu no momento em que as políticas fundiárias começaram a se configurar como uma resposta às pressões dos movimentos sociais no campo (fim dos anos 1950 e início de 1960) (BERGAMASCO \& NORDER, 1996).

Em uma definição genérica, podemos dizer que

[...] os assentamentos rurais podem ser definidos como a criação de novas unidades de produção agrícola, por meio de políticas governamentais visando o reordenamento do uso da terra, em benefício de trabalhadores rurais sem terra ou com pouca terra. Como seu significado remete à fixação do trabalhador na agricultura, envolve também a disponibilidade de condições adequadas para o uso da terra e o incentivo à organização social e à vida comunitária (BERGAMASCO \& NORDER, 1996, pp. 7-8).

Um assentamento pode ser fruto de colonização dirigida, de reassentamento como no caso dos atingidos pelas construções de barragens, da reforma agrária e da regularização fundiária (BERGAMASCO \& NORDER, 1996). No caso aqui em estudo, a comunidade JutaíMirim, o assentamento foi criado em terras de antiga ocupação, ou seja, é fruto de regularização fundiária. Isto foi verificado in loco por meio do histórico das famílias na posse e confirmado por estudo realizado pela Universidade Federal do Pará (UFPA), em 2003, sobre o processo de ocupação no entorno do rio Bujaru.

O Projeto de Assentamento foi criado com a Portaria $n^{\circ} 110$, de 27 de dezembro de 2006, do INCRA/PA (CNA, 2009). Ele possui uma área de 2.265,7652 ha, onde foram criados 80 lotes com aproximadamente 25 ha cada (INCRA, 2008a). Apesar deste número de lotes, somente 52 famílias haviam sido cadastradas, pois no momento do cadastro, havia algumas que não queriam o assentamento, ou porque queriam o território quilombola ou porque preferiam a titulação desvinculada destas propostas. Com o passar do tempo, as famílias que não queriam o assentamento realizaram seu cadastro para a segunda etapa do assentamento. Isto porque, segundo um morador, não se falou mais em titulação coletiva e seus vizinhos já estavam no assentamento. Para não ficar isolado, fez o cadastro.

Para a implantação do assentamento foi necessário constituir uma associação, cuja legalização demorou. Por isso, em maio de 2007, foi realizada uma reunião sob a coordenação do então presidente do STR de Concórdia do Pará, com o objetivo de escolher três pessoas para formarem uma comissão que teria como tarefas: a organização dos assentados e sua 
representação em todas as instâncias; a fundação da associação no prazo de noventa dias; a abertura de conta bancária e a administração dos recursos do programa de reforma agrária. Também foi estabelecido que cada assentado contribuiria com uma taxa de R \$25,00 depois que recebesse o primeiro crédito, para custear os gastos da comissão.

Foi somente em 2008 que a comissão realizou uma assembléia para eleger a diretoria da associação denominada Associação dos Trabalhadores do Assentamento Jutaí e Ipanema (ATAJI). O nome Ipanema vem de outra comunidade vizinha, em que parte das famílias não aceitou a titulação coletiva das terras ali realizada, passando então a fazer parte do assentamento que estava sendo criado em Jutaí-Mirim. Inicialmente, as famílias foram contempladas com o crédito instalação (modalidade apoio inicial e modalidade aquisição de materiais de construção para 51 casas) e com recursos para a construção de $20 \mathrm{~km}$ de estradas vicinais de acesso aos lotes, energia e água. (INCRA, 2008a).

As famílias receberam em mercadoria os valores de $\mathrm{R} \$ 2.400,00$, sendo $\mathrm{R} \$ 500,00$ para alimentação e o restante para outras compras, como instrumentos de trabalho, bicicletas, fogões e geladeiras. Para a compra de alimentos as famílias foram encaminhadas pela comissão para um dos supermercados de Concórdia do Pará e para as demais compras, a comissão é que era a responsável por realizá-las, também em lojas de Concórdia do Pará.

As casas que foram construídas, ou pelo menos iniciadas, ficam em uma agrovila criada pelo INCRA (Foto 2) e em alguns lotes. As que estão na agrovila, no total de 30, estão terminadas, mas poucas estão ocupadas pelas famílias. A explicação é que as famílias ainda não haviam mudado porque as casas ficam longe de seus lotes, onde fazem suas roças, produzem a farinha e criam seus animais. Além disto, a agrovila é vista por alguns moradores como um local barulhento e com muita gente aglomerada. Por isso, preferem a tranqüilidade do seu lote. 


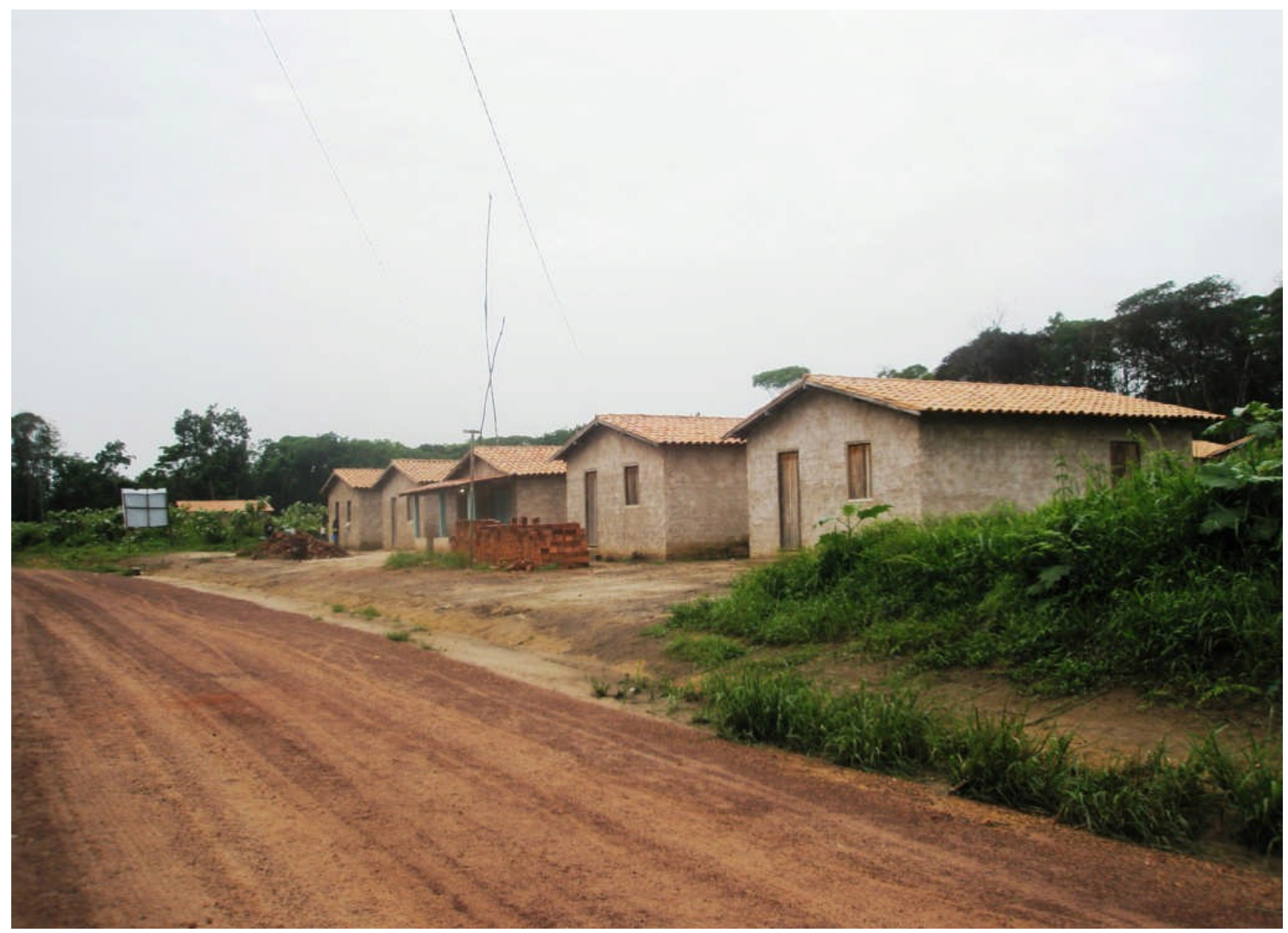

Foto 2: Casas da agrovila construídas pelo INCRA (foto da autora em jan./2009).

As casas que ficam no lote estão lá porque as famílias pediram, mas nem todas tiveram seus pedidos atendidos, pois segundo a explicação dada pelo INCRA, o acesso a alguns lotes era difícil pela existência de áreas de igapó e igarapés. Isto fez com que algumas famílias tivessem que aceitar a casa na agrovila. A maioria das casas construídas nos lotes ainda não foi terminada e outras nem iniciadas, o que gera grande insatisfação e queixa das famílias.

Além da casa da agrovila ficar, para muitas famílias, distante de seus lotes, existe uma outra situação que pode ser considerada como um motivo para ficar no lote familiar. É muito comum a prática dos filhos, após constituírem família, de construírem suas residências ao lado da casa dos pais. Isto permite que, mesmo com o casamento, o pai ainda possa contar com a ajuda do filho nos trabalhos do lote e vice-versa (Foto 3). Na agrovila esta prática de morar ao lado não poderia ocorrer, pois não há espaço para a construção de novas casas. 


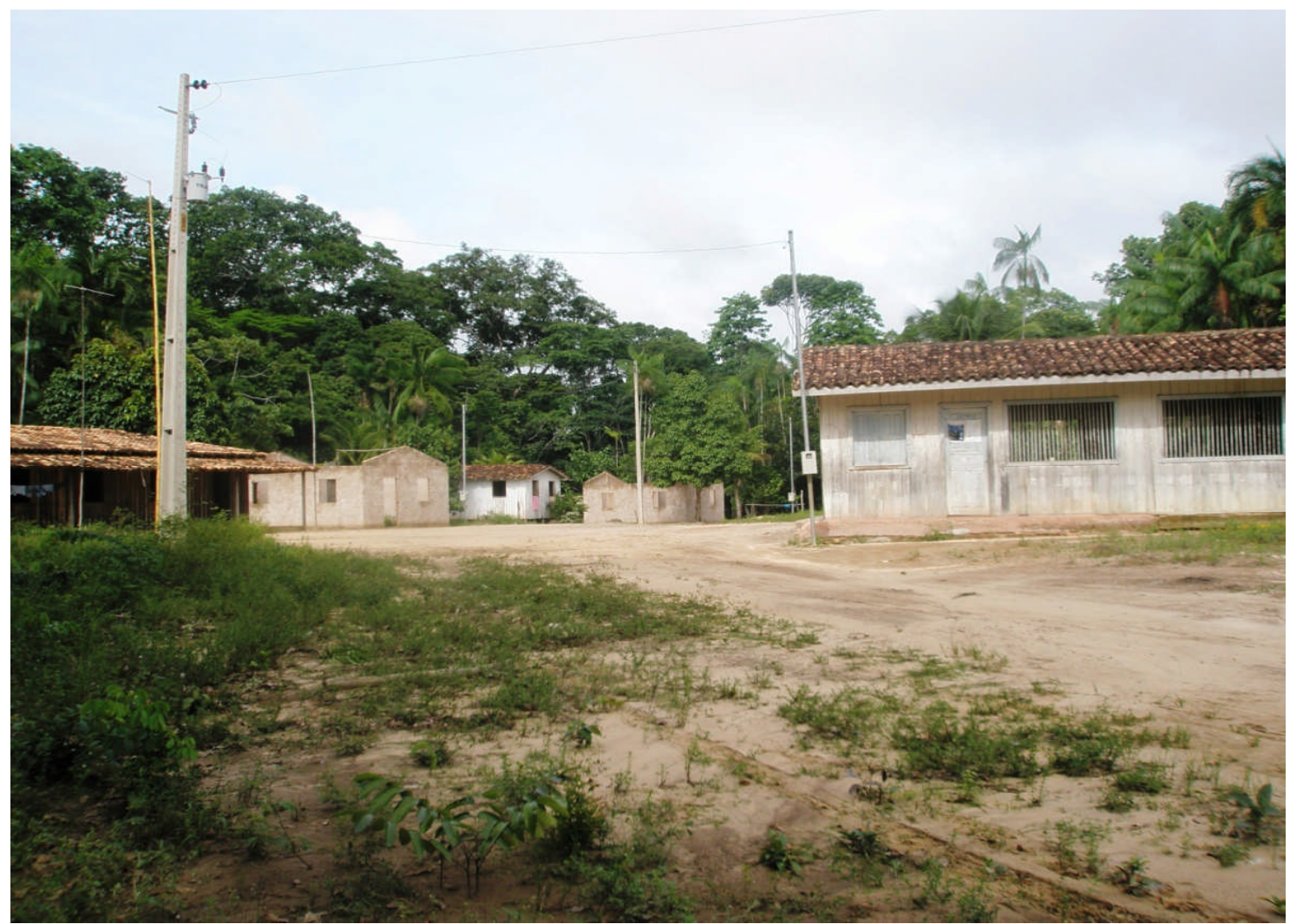

Foto 3: Conjunto de casas de madeira e de alvenaria formado pela casa da mãe e dos filhos casados. Cada filho teve o início da construção de sua casa feito pelo INCRA bem lado da sua de madeira que já existia. As outras casas estão por trás da escola que está à direita (foto da autora em jan./2009).

Uma situação que chama a atenção neste processo de criação de assentamento é que as terras, que na sua maioria são de herança, possuem uma área bem maior que a que o INCRA estabeleceu por família, os 25 ha. Diante desta situação, os pais se vêem obrigados a fazer a divisão das terras entre os filhos, mesmo que estes ainda não tenham constituído família. Esta seria a estratégia utilizada para manter as terras com a família. É o Estado impondo suas regras de acesso à terra, ditando quem, quanto pode ser acessado e quando, contrapondo-se assim às formas tradicionais de acesso realizadas de acordo com as necessidades da família. Esta divisão das terras entre os filhos não quer dizer necessariamente que estes passem a morar nestes lotes recortados pelo INCRA, e nem que o lote vá ser logo utilizado para algum cultivo, pois o seu uso depende muito da necessidade de produção da família, da força de trabalho disponível e da quantidade e qualidade das terras ainda disponíveis para o cultivo.

As opiniões sobre a criação do assentamento são diversas. Para os poucos que moram na agrovila a criação foi importante, pois já estão com as casas construídas, água encanada, energia. Para algumas famílias que optaram pela casa no lote, a opinião é de insatisfação porque o INCRA iniciou a construção das casas e não terminou. Algumas estão somente com 
as paredes levantadas, outras já possuem um teto, outras nem sequer foram levantadas. Elas se queixam da demora das obras, mas esperam que logo o assentamento seja concluído.

\subsection{O Programa Terra Legal Amazônia e Nova Esperança}

\subsubsection{O Programa}

O Terra Legal Amazônia é um programa do governo federal, coordenado pelo Ministério do Desenvolvimento Agrário (MDA) ${ }^{47}$ e desenvolvido em parceria com estados e municípios visando regularizar 67,4 milhões de hectares de terras da união ocupadas por posseiros na Amazônia ${ }^{48}$ (BRASIL, 2010).

Pelo referido programa serão regularizadas as ocupações de terras de até 15 módulos fiscais e não superiores a 1.500 ha. Os ocupantes de terras, cujos tamanhos sejam inferiores à fração mínima de parcelamento, terão preferência como beneficiários na implantação de novos projetos de reforma agrária na Amazônia Legal (BRASIL, 2010). A ação busca regularizar 296.861 posses $^{49}$ que sejam anteriores a $1^{\text {o }}$ de dezembro de 2004. Estas posses estão localizadas em 436 municípios dos nove estados da Amazônia Legal ${ }^{50}$. Do total de posses a serem regularizadas, 89.785 estão em 86 municípios do Pará (Tabela 3).

\footnotetext{
${ }^{47}$ De acordo com a Lei ${ }^{\circ} 11.952$, de 2009, ficam transferidas do INCRA para o MDA, pelo prazo de cinco anos renovável por igual período, as competências para coordenar, normatizar e supervisionar o processo de regularização fundiária de áreas rurais na Amazônia Legal, expedir os títulos de domínio e efetivar a doação prevista na lei.

${ }^{48}$ Segundo os dados oficiais de 2003, o Instituto Nacional de Colonização e Reforma Agrária (INCRA) discriminou nos estados 105,8 milhões de hectares. Desse total, continuam sem destinação 67,4 milhões de hectares (Repórter Brasil, 2010).

${ }^{49}$ Em uma página do site estão 296.856 mil posses e em outra 296.859. Preferi o total de 296.861, que é um outro número no site, porque é o que surge dos cálculos por estado e por módulo fiscal.

${ }^{50}$ Acre, Rondônia, Mato Grosso, Amazonas, Pará, Maranhão, Tocantins, Amapá e Roraima.
} 
Tabela 3 - Número de posses por estado e módulo fiscal

\begin{tabular}{lrrrrr}
\hline \multicolumn{1}{c}{ Estados } & $\begin{array}{c}\text { Municípios } \\
\text { Abrangidos }\end{array}$ & \multicolumn{1}{c}{ Até 1 MF } & \multicolumn{1}{c}{ 1 $\mathbf{~ a ~ 4 ~ M F ~}$} & 4 a 15 MF & $\begin{array}{c}\text { Total de } \\
\text { Posses }\end{array}$ \\
\hline Acre & 9 & 7.898 & 5.445 & 28 & 13.371 \\
Amapá & 15 & 10.834 & 1.779 & 986 & 13.599 \\
Amazonas & 37 & 27.277 & 30.070 & 1.194 & 58.541 \\
Maranhão & 28 & 5.525 & 2.928 & 304 & 8.757 \\
Mato Grosso & 106 & 13.722 & 9.845 & 1.946 & 25.513 \\
Pará & $\mathbf{8 6}$ & $\mathbf{5 8 . 9 4 2}$ & $\mathbf{2 5 . 8 7 7}$ & $\mathbf{4 . 9 6 6}$ & $\mathbf{8 9 . 7 8 5}$ \\
Rondônia & 51 & 31.459 & 10.611 & 1.670 & 43.740 \\
Roraima & 15 & 23.778 & 2.986 & 1.542 & 28.306 \\
Tocantins & 89 & 7.181 & 7.486 & 582 & 15.249 \\
\multicolumn{1}{c}{ Total } & $\mathbf{4 3 6}$ & $\mathbf{1 8 6 . 6 1 6}$ & $\mathbf{9 7 . 0 2 7}$ & $\mathbf{1 3 . 2 1 8}$ & $\mathbf{2 9 6 . 8 6 1}$ \\
\hline
\end{tabular}

A primeira etapa do processo de regularização é o cadastro no Sistema Terra Legal (SISTERLEG). Para isso, as famílias precisam apresentar um documento de identificação com foto e CPF (pessoal e do cônjuge), cópia de documento referente à posse da terra, se possuir, e informações detalhadas da localização da propriedade. Depois disto, as posses serão georreferenciadas, as informações processadas e, posteriormente, ocorre a entrega do título no prazo de 120 dias, contado a partir do cadastramento. Este prazo é válido para situações nas quais não exista contestação sobre a ocupação do imóvel ou litígio judicial (BRASIL, 2009b).

A entrega do título, de acordo com a Lei ${ }^{\circ} 11.952$, de 2009, que dispõe sobre a regularização fundiária das ocupações em terras da União, no âmbito da Amazônia Legal, segue os seguintes critérios:

- até um módulo fiscal a titulação será gratuita e o processo será concluído em até 120 dias, contados a partir do cadastramento da posse;

- entre um e quatro módulos fiscais será cobrado pela terra um valor inferior ao preço de mercado, com 20 anos para pagamento e três anos de carência, e não terá licitação. O processo será concluído em até 120 dias, contados também a partir do cadastramento da posse. Estes beneficiários terão direito de acesso ao programa Nossa Terra, Nossa Escola ${ }^{52}$;

\footnotetext{
${ }^{51}$ Na tabela do Site do MDA, o total é de 186.614, mas refazendo os cálculos, o correto é os 186.616.

${ }^{52} \mathrm{O}$ programa estabelece um incentivo financeiro às famílias assentadas que mantêm seus filhos, de sete a 14 anos, na escola, até a conclusão do ensino fundamental. O incentivo é concedido na forma de abatimento de $50 \%$ do valor devido nas prestações da terra (NEAD, s/d).
} 
- entre quatro e 15 módulos fiscais o valor da área será o de mercado, descontadas as benfeitorias, com regras de pagamento semelhantes às das áreas de um a quatro módulos fiscais, e não terá licitação. A titulação será precedida de vistoria do imóvel para avaliação das benfeitorias e do tempo de ocupação da terra. O prazo é de 120 dias para a entrega do título, contados a partir do cadastramento. Este prazo é válido, como nos outros casos, para situações nas quais não exista contestação sobre a ocupação do imóvel ou litígio judicial (BRASIL, 2009b).

As terras em áreas de várzea e beira de rio também serão regularizadas mas, pela Constituição, estas terras não podem ser vendidas pelo governo federal. Nesses casos, a Secretaria de Patrimônio da União (SPU) emitirá uma Concessão de Direito Real de Uso (CDRU) para quem está na terra. As terras ocupadas só poderão ser tituladas até os 15 módulos fiscais estabelecidos pelo programa, observado o limite máximo de 1.500 ha. Caso a área exceda aos 1.500 ha a regularização será condicionada à desocupação da área excedente. As terras que excederem serão revertidas ao patrimônio da União (BRASIL, 2009b).

O título de domínio ou o termo de concessão de direito real de uso deverão conter cláusulas sob condição resolutiva pelo prazo de dez anos, que determinem o aproveitamento racional e adequado da área, a averbação da reserva legal, a identificação das áreas de preservação permanente, a observância das disposições que regulam as relações de trabalho, e as condições e forma de pagamento (BRASIL, 2009b). Os títulos referentes às áreas de até quatro módulos fiscais serão intransferíveis e inegociáveis por ato inter vivos pelo prazo de dez anos, e os títulos referentes a áreas superiores a 4 (quatro) módulos fiscais, decorridos três anos da titulação, poderão ser transferidos a terceiro. (BRASIL, 2009b). A idéia do programa é que, ao entregar o título de propriedade, o Terra Legal Amazônia leve segurança jurídica aos produtores rurais da Amazônia Legal e reforce as políticas públicas de preservação do meio ambiente na região (BRASIL, 2010). O que precisa ser visto é se de fato e em que medida essa segurança e essa preservação se efetivam.

O Programa Terra Legal Amazônia possui como fundamentação legal, dentre outras, a lei $\mathrm{n}^{\mathrm{o}} 11.952$, de 25 de junho de 2009, regulamentada pelo decreto $\mathrm{n}^{\circ} 6.992$ de 2009. Esta lei é a conversão da Medida Provisória (MP) 458, de 10 de fevereiro de 2009, que possibilitou a 
aquisição das terras até 2.500 ha, dando preferência aos seus detentores. Anteriormente a esta MP, houve a MP 422, de 25 de março de 2008 (convertida em Lei $\mathrm{n}^{\circ} 11.763$, de $1^{\circ}$ de agosto de 2008), que legitima a apropriação das terras públicas na Amazônia legal com área até 1.500 ha. De acordo com Oliveira (2009), todas essas medidas são fruto de uma mudança de orientação política do governo federal a partir de 2008, quando o mesmo optou pela regularização fundiária em detrimento da reforma agrária.

A justificativa do governo para a legalização das terras públicas, para Oliveira (2009), é uma farsa populista. Isto porque o discurso do governo é de que a regularização vai beneficiar os pequenos posseiros. Todavia estes posseiros ocupam apenas $20 \%$ das terras. Outro fato que evidencia a não preocupação com os pequenos é que, nos primeiros seis anos do governo Lula, o INCRA regularizou apenas $17 \%$ da meta de regularização estabelecida no II PNRA. Assim, a legalização das terras beneficia os grileiros do agronegócio que, de forma ilegal, apoderam-se das terras públicas do INCRA. Isto revela que o INCRA não vai solicitar na justiça a reintegração de posse de suas terras griladas, como manda a legislação em vigor, mas vai tentar garantir as terras griladas para o que o autor chama de agrobanditismo. Esta situação está relacionada à contínua violência na Amazônia.

De acordo com Oliveira (2009), esta opção pela regularização da grilagem revela que o governo está substituindo a política de reforma agrária pela política de regularização fundiária. Com a opção pela regularização, consolida-se a vitória do agronegócio na questão agrária brasileira e a adesão definitiva da política agrária e fundiária do MDA/INCRA aos interesses dos grileiros. A assinatura da MP 422 e da MP 458 reflete a consolidação da contra reforma agrária do governo petista no segundo mandato.

Apesar das críticas ao governo federal, a Medida Provisória 458 converteu-se na lei $\mathrm{n}^{\mathrm{o}}$ 11.952 em 2009, e possibilitou o início das regularizações das terras na Amazônia. Este processo de regularização ocorre por meio do Programa Terra Legal Amazônia que atinge diversas comunidades rurais na região, inclusive uma das que são objeto deste estudo: Nova Esperança. 


\subsubsection{Nova Esperança ou Velho Expedito?}

Em Nova Esperança, o debate sobre a titulação das terras se inicia com a discussão sobre a possibilidade da comunidade pertencer ao território quilombola que estava em processo de identificação em 2001 pela ARQUINEC. Nesse processo uma ficha de cadastro foi entregue às famílias para que se associassem à ARQUINEC e a partir deste momento começassem a receber cestas básicas do programa Fome Zero, do governo federal. Para esta associação era cobrada uma taxa de dez reais. Segundo uma das moradoras, muita gente não sabia para quê era a ficha.

Vendo a ação da ARQUINEC na comunidade, o STR de Concórdia do Pará intervém, orientando as famílias para não preencherem a ficha porque era uma propaganda enganosa. A partir daí a ARQUINEC passou a ser acusada de vender cestas básicas por pessoas da comunidade. Isto gerou muito desentendimento entre as famílias que aderiram à proposta da ARQUINEC e as que não aderiram, e se acirraram ainda mais os conflitos entre STR (que possuía uma posição contrária à titulação coletiva) e ARQUINEC.

Em 2006, chegaram para as famílias diversas cestas básicas do governo federal $^{53}$. E neste mesmo ano, a ARQUINEC foi acusada de vender estas cestas por alguns moradores. Como resultado destas acusações, o INCRA de Tomé-Açu cancelou o envio de mais cestas. Em março de 2006 a ARQUINEC emitiu uma nota de esclarecimento com cerca de 392 assinaturas de famílias de 13 comunidades sobre essa acusação. A nota esclarecia que ao mesmo tempo em que ocorria a entrega das cestas básicas, era realizada a associação das famílias à ARQUINEC para que se iniciasse o processo de reconhecimento, e que, para esta associação era cobrada uma taxa. Portanto, segundo a nota, não havia venda de cestas. A nota de esclarecimento da ARQUINEC também denunciava a existência de pessoas, sem indicar quem, que promoviam uma campanha contra a titulação coletiva das terras no município (ARQUINEC, 2006).

Mesmo com todos estes desentendimentos, o pedido de registro como remanescentes dos quilombos na Fundação Cultural Palmares continuou tramitando e em 27 de novembro de 2006, Nova Esperança foi registrada como Comunidade Velho Expedito ${ }^{54}$, no Livro de

\footnotetext{
${ }^{53}$ Estas cestas básicas foram cedidas pelo governo federal a partir de pedidos da ARQUINEC de inclusão de diversas comunidades junto ao Programa Fome Zero.

${ }^{54} \mathrm{O}$ nome se refere ao senhor Expedito Ferreira, morador da comunidade desde a década de 1970. Sua família é uma das que aceitaram o reconhecimento.
} 
Cadastro Geral $n^{\circ} 08$ da FCP, com registro $n^{\circ} 828$, na folha 40. (BRASIL, 2006). Houve uma cerimônia na Câmara de Vereadores de Concórdia do Pará para o recebimento do registro, não só de Nova Esperança, mas de outras oito comunidades.

O registro suscitou uma reação das lideranças da comunidade que não apoiaram esta iniciativa. Para reafirmar sua posição contra o reconhecimento como quilombolas e a mudança de nome, o grupo de lideranças de Nova Esperança construiu uma placa indicando o nome e a localização da comunidade (Foto 4). Nesta localização, delimitam onde começa e termina, deixando de fora algumas das famílias que queriam a titulação coletiva. Outras que eram a favor ficaram dentro deste limite por se acharem divididas entre a coletiva e a individual.

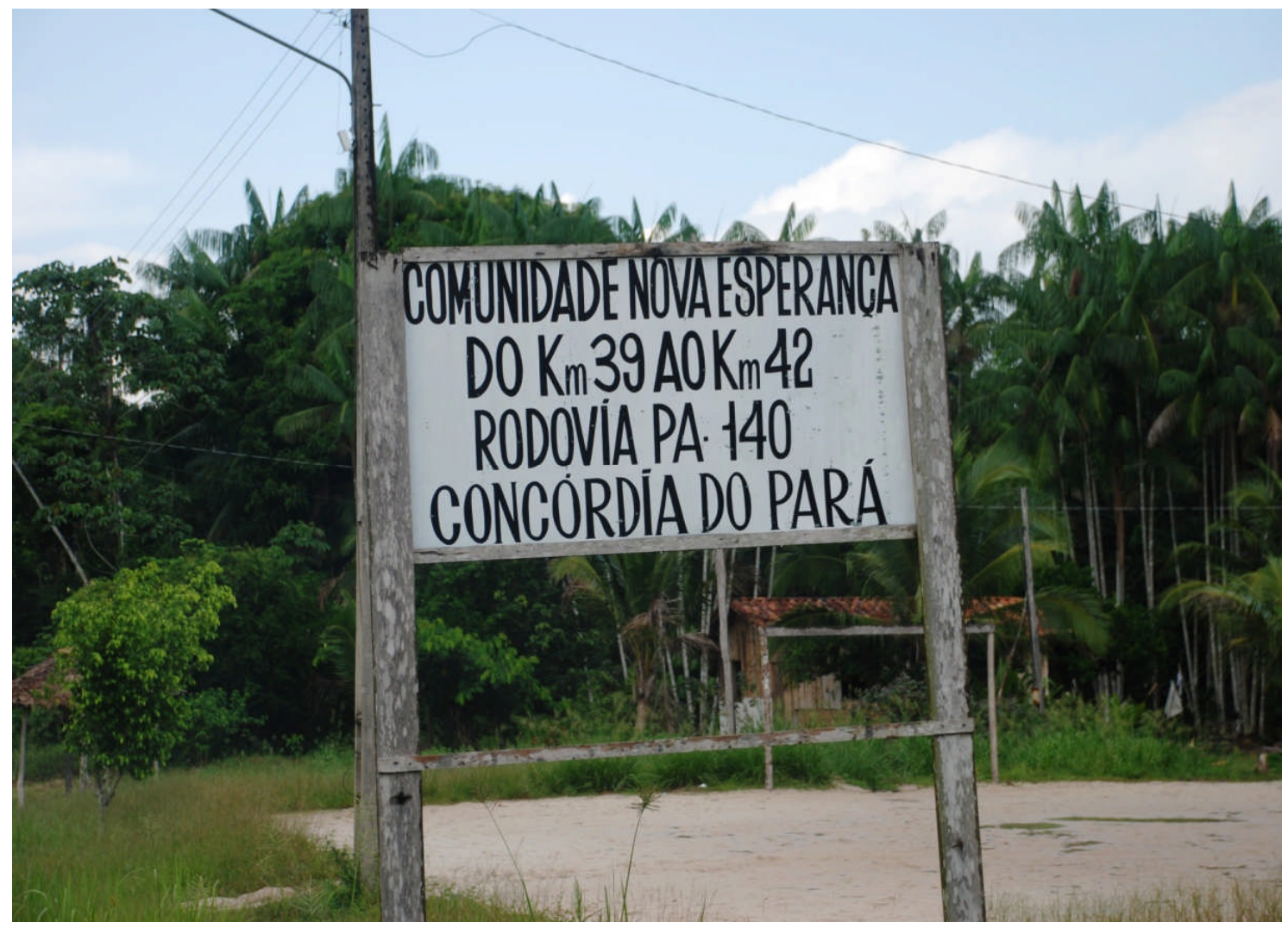

Foto 4: Placa colocada no arraial da comunidade indicando o seu nome e localização (Valéria de Marcos em fev./2010).

$\mathrm{O}$ argumento das lideranças é que em Nova Esperança nunca houve quilombo, as famílias são originárias de outros municípios paraense e até de fora do estado do Pará e ali chegaram somente na década de 1970, com a construção da rodovia PA 140. Além disso, ninguém foi até a comunidade para fazer o laudo antropológico.

De fato muitas famílias não têm sua origem no município, mas existem aquelas que foram constituídas pelo casamento de quem chegou de fora com quem já era morador(a) das 
comunidades vizinhas. A vinda destas famílias ocorre na década de 1970 com a construção da PA 140. É com base nesta origem migrante e no tempo de ocupação recente das terras que se repudia a idéia de quilombo, que aparece nas falas de seus moradores como o local escondido, para onde os escravos fugiam e moravam na época da escravidão. Sendo assim, segundo as lideranças, para que a comunidade fosse reconhecida como quilombola era preciso que na sua história existisse o quilombo e a antiguidade da ocupação.

Este pensamento sobre quilombo está muito relacionado com a definição do Conselho Ultramarino Português de 1740 e que foi reproduzido por décadas pelo Direito, pela academia e pelo senso comum (ALMEIDA, 2002). Tal entendimento acaba dificultando a ação das diversas entidades que defendem o reconhecimento dos territórios quilombolas.

A idéia da titulação coletiva também é combatida com a justificativa de que as famílias não trabalham de forma coletiva e sim cada uma na sua posse, de forma individual, portanto a titulação deve ser individual. A compreensão que se tem do coletivo é em relação ao trabalho na posse e não, de acordo com Leite (2000), ao modo de vida coletivo, à participação de cada família no dia-a-dia da vida em comunidade, ao esforço de consolidação do grupo.

A questão do laudo antropológico é um outro problema. Isto porque as diversas comunidades de Concórdia do Pará estão sendo identificadas como quilombolas com base em um estudo realizado pela UFPA em $2003^{55}$. Este estudo retrata a história de ocupação e de escravidão ao longo do rio Bujaru. Dando ênfase à comunidade São Judas Tadeu, no município de Bujaru, acabou sendo utilizado pelo INCRA para justificar o reconhecimento como quilombola da São Judas e das comunidades de Concórdia do Pará como Dona, Campo Verde, Santo Antônio e Ipanema. Foi também com base no estudo da UFPA que a ARQUINEC buscou o reconhecimento das comunidades que ficam no entorno do rio Bujaru e seus afluentes. Além deste estudo foi feita a cartografia social dos quilombolas no município onde a associação apontou quais as comunidades que estão ligadas a ela.

A questão que envolve Nova Esperança é que nenhum estudo foi feito na comunidade, não sendo possível, segundo as lideranças, aceitar um estudo realizado em outros lugares para dizer que lá é quilombola. A comunidade só conseguiu a certidão da FCP porque a ARQUINEC e mais cinco pessoas que estavam interessadas no reconhecimento assinaram o pedido de registro como comunidade quilombola. Em 2006, quando ocorreu o

55 CASTRO, Edna. Quilombolas de Bujaru: Memória da escravidão, territorialidade e titulação da terra. Belém: Secretaria de Justiça do Estado; UNAMAZ, 2003. 1 CD-ROM. 
reconhecimento da comunidade como remanescente de quilombo, vigorava a Portaria da FCP $\mathrm{n}^{\mathrm{o}}$ 6, de $1^{\mathrm{o}}$ de março de 2004, que exigia que a declaração de remanescência deveria ser feita por representante legal da associação ou, na falta deste, por pelo menos cinco membros da comunidade declarante (BRASIL, 2004).

$\mathrm{O}$ argumento da ARQUINEC é que por mais que a origem da comunidade seja recente, é preciso levar em consideração que muitos negros foram expulsos de suas terras ou mesmo constituíram famílias e precisaram migrar, formando novas comunidades em novos lugares. Esta migração não seria motivo para que estas comunidades formadas recentemente, mas por pessoas das proximidades, não tivessem direito de ter suas terras tituladas como remanescentes dos quilombos.

O argumento da ARQUINEC parte da compreensão de que trata Leite (2000). A autora afirma que o artigo 68 vem requerer uma extensão da cidadania a todas as comunidades negras cuja resistência remonta a uma memória da escravidão passível de ser reconstituída pelas redes de parentesco e afinidades que conformam a malha do grupo. Devese incluir grupos que já foram expulsos de suas terras e aquelas famílias que têm as mesmas características, mas que não se autodenominam como quilombola, principalmente por não disporem de organização e meios para a formulação de um discurso articulado nos mesmos termos das que já se autodefinem.

Argumentos à parte, a questão é que as lideranças de Nova Esperança, apoiadas pelo STR, e a ARQUINEC, apoiada pela CPT, têm formas diferentes de ver como regularizar suas terras. Para a associação, é muito mais que apenas regularizar, é uma questão de garantir a permanência para quem já vive na/da terra. A insistência da ARQUINEC para a titulação das terras como coletiva dá-se também, e principalmente, porque existem duas empresas, a Dendê Tauá e a Biovale (o nome anterior era Biopalma), que estão atuando no município comprando terras dos camponeses e fazendeiros para o cultivo do dendê. Uma delas, a Biovale, já está inclusive comprando terras de famílias de Nova Esperança e das comunidades vizinhas.

A Biovale (Foto 5) não atua somente na compra de terras (cerca de R $20.000,00$ um lote com 25 ha). Aos camponeses que não querem vender ela age oferecendo uma parceria, na qual a empresa financiaria o cultivo e os camponeses plantariam o dendê em suas terras, e o entregariam para a empresa. Esta forma de atuação nos mostra como o capital busca se territorializar e/ou monopolizar o território, expulsando o camponês ou sujeitando a sua renda.

De acordo com Oliveira (2005), o capital se territorializa quando o capitalista da indústria, o proprietário de terra e o capitalista da agricultura são um só, utilizando-se do trabalho assalariado para produzir. Ele, o capital, monopoliza o território quando o capitalista 
da indústria é um, e o proprietário de terra e o trabalhador são uma só pessoa: o camponês. Estes são processos contraditórios do desenvolvimento capitalista no campo, pelos quais há a contínua criação e recriação do campesinato.

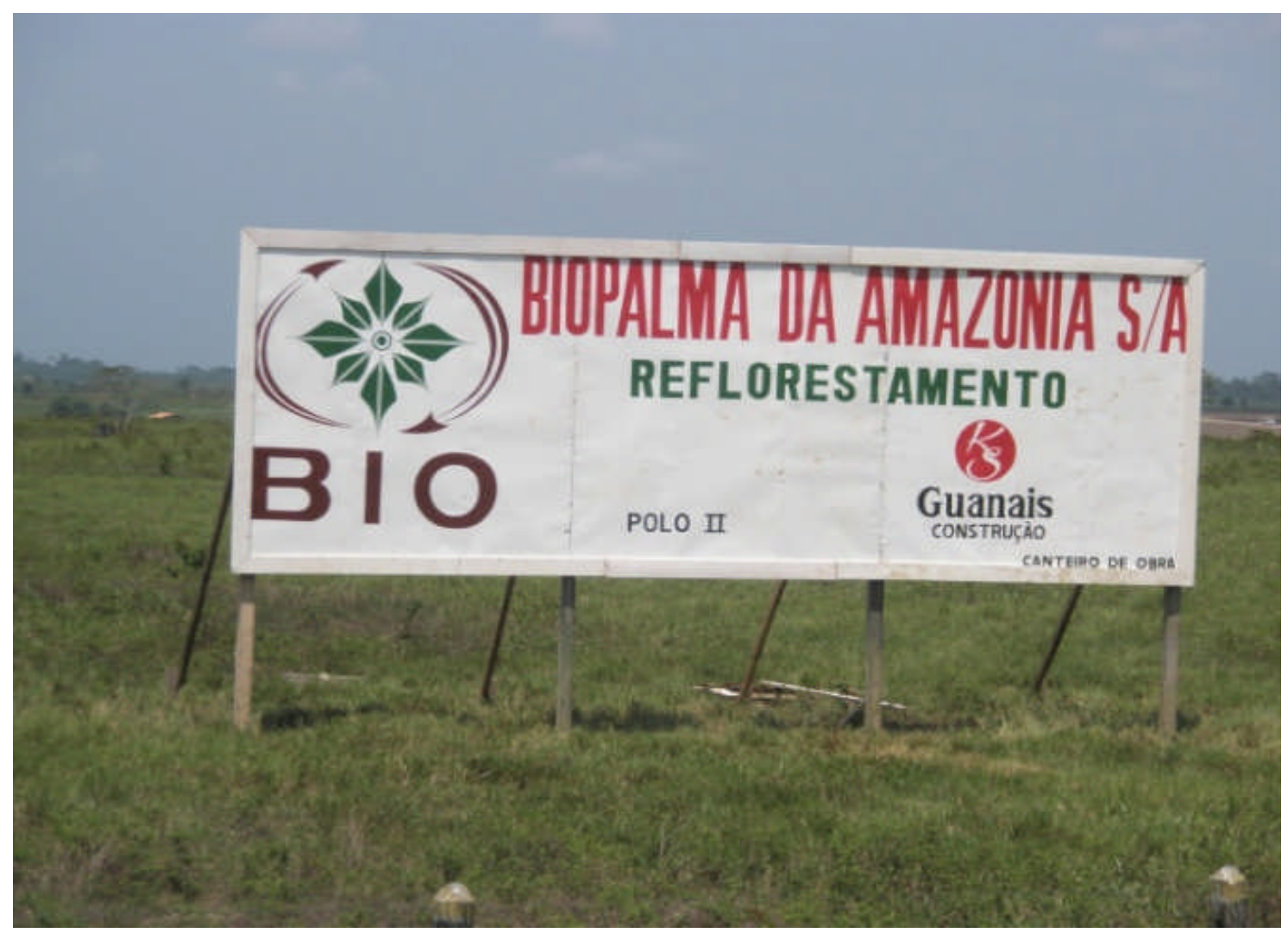

Foto 5: Placa de identificação da empresa na fazenda comprada por ela da família Fonteles (foto da autora em out./2008).

Tanto a ARQUINEC quanto o STR consideram a instalação da empresa como um fato já consumado. O desafio que se apresenta é de como se relacionar com ela. Para a ARQUINEC, a titulação coletiva das terras é vista como uma forma de barrar o avanço da empresa sobre as terras de diversas comunidades do município. Aqui, a autodefinição enquanto quilombola tem o papel político fundamental para a manutenção do campesinato no município. Mas esta não é uma compreensão que gera um consenso entre estas entidades. Em uma das reuniões com a ARQUINEC, um dos moradores de Nova Esperança propôs que se fizesse o reconhecimento como quilombola somente das famílias que se autodefiniam, enquanto que as demais iriam buscar outras formas de conseguir a titulação, certamente individual. Todavia, entre as terras das famílias que se autodefinem existem terras de famílias que pretendiam vender suas posses. Para estas famílias que queriam vender, a proposta foi a de que o INCRA indenizasse e incluísse suas terras no território quilombola a ser criado. Com 
a aceitação destas propostas, poderia ser criado o território quilombola somente em parte da comunidade. Segundo este morador, o próprio INCRA afirmou não poder fazer o território quilombola em toda a área que estava sendo reivindicada, pois abrangia uma grande área do município onde existiam muitos agricultores, fazendeiros e muitas famílias precisando de terras.

Na busca de um entendimento sobre qual seria efetivamente a área a ser reconhecida como território quilombola e a compra e venda de terras em áreas onde já havia a certificação da FCP, pela Biovale, foram realizadas diversas reuniões entre STR, ARQUINEC, prefeitura e as empresas de dendê que atuam no município. Em uma delas, na Câmara Municipal de Concórdia do Pará, as empresas afirmaram que não estavam comprando terras dos camponeses. Todavia não é o que observamos andando pela comunidade (Fotos 6 e 7).

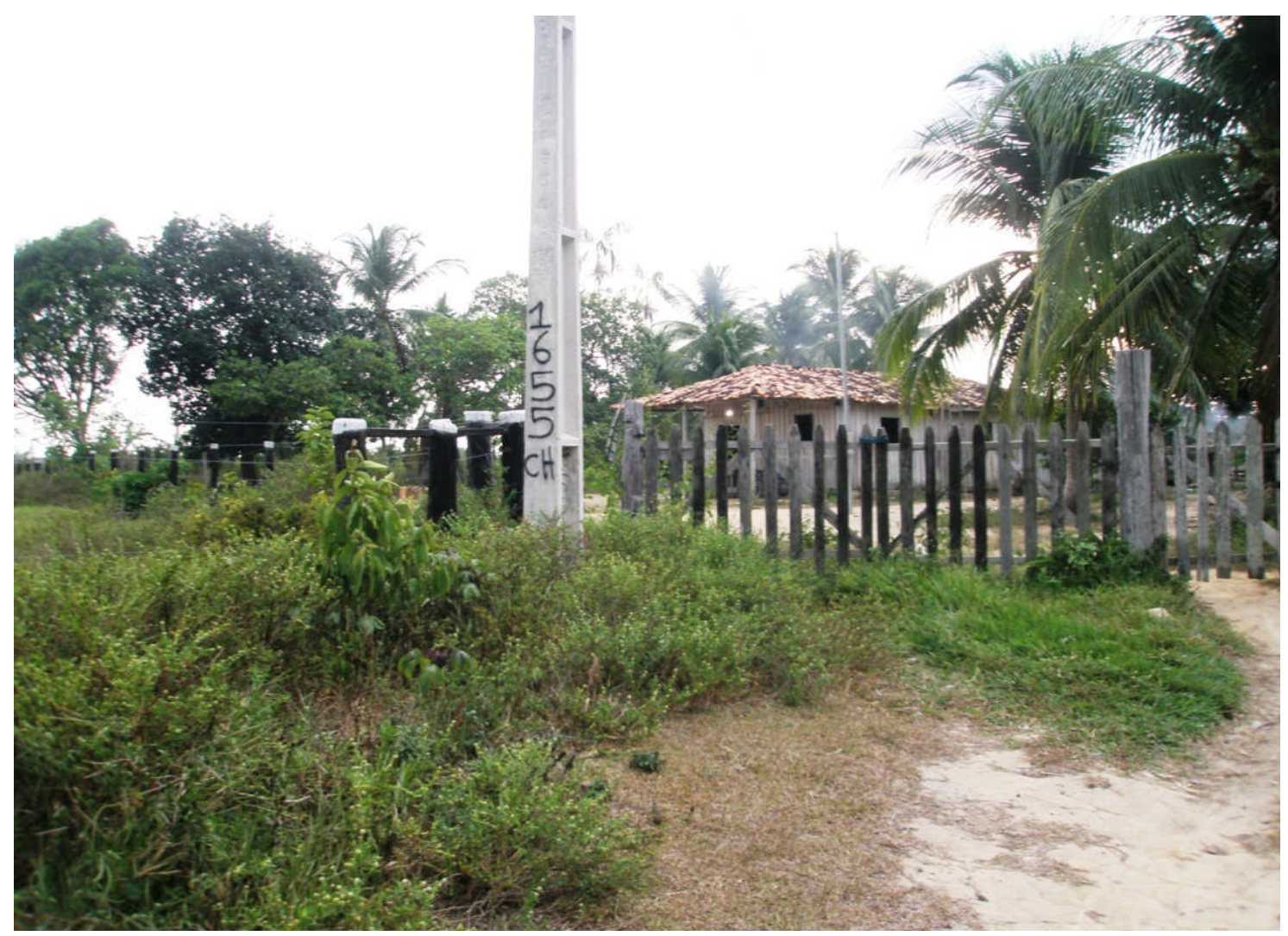

Foto 6: Posse de um dos moradores de Nova Esperança que foi vendido para a Biovale. Observe à esquerda, a cerca da fazenda (foto da autora em nov./2008). 


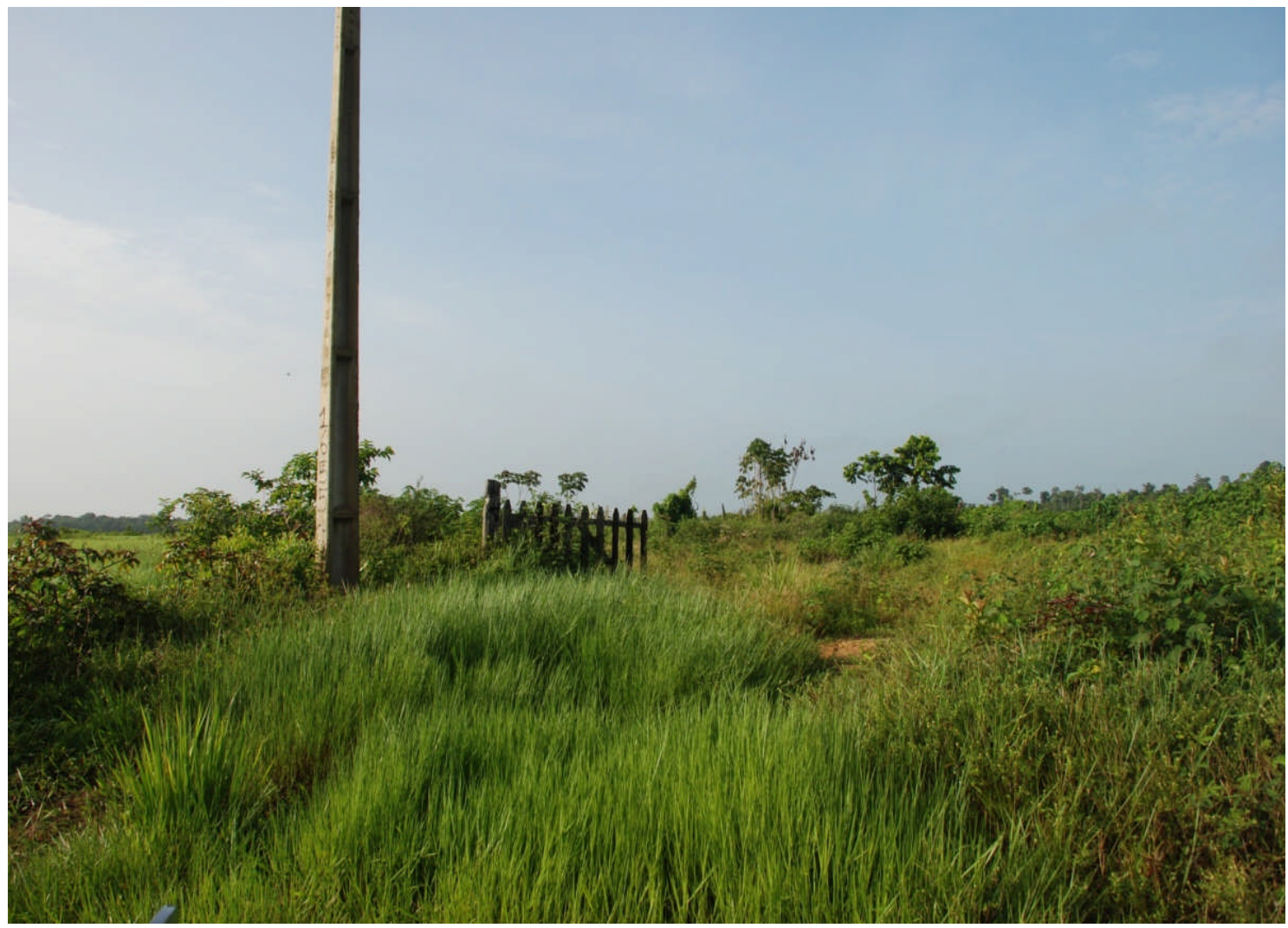

Foto 7: A mesma propriedade da foto anterior, após a venda. Já não existem mais nem a cerca da fazenda, nem a casa dos moradores (Valéria de Marcos em jan./2010).

Apesar de não concordarem com a ação da ARQUINEC em relação à comunidade, algumas lideranças reconhecem que graças a ela a empresa não pôde mais avançar sobre as terras camponesas, principalmente as certificadas pela FCP, apesar de já ter comprado várias posses em Nova Esperança. As demais comunidades que se autodefiniram, mas que não tiveram suas terras reconhecidas como remanescentes de quilombos pela FCP sofrem com a saída das famílias e a venda de suas terras para a Biovale pois se sentem cada vez mais pressionadas, e até cercadas de fato pelo dendê. Um representante do INCRA de Tomé-Açu, ao ser questionado sobre a atuação da empresa, afirmou que não pode fazer nada. Vai esperar que a empresa os procure para regularizar as posses.

Várias reuniões se seguiram entre ARQUINEC, INCRA, STR, prefeitura, Biovale e lideranças comunitárias. Por fim, o debate sobre a titulação coletiva parou, a ARQUINEC não mais insistiu, mesmo que Nova Esperança tenha a certidão da FCP, e as pouquíssimas famílias que apoiavam a associação só podem contar com esta certidão. O STR manteve sua posição em apoio às lideranças contra a titulação coletiva, e a Biovale iniciou o cultivo do dendê nas posses já compradas. Este é somente um capítulo da história de Nova Esperança.

Apesar de ter sido certificada em 2006 pela FCP, Nova Esperança (ou Velho Expedito, como foi cadastrada) também vivencia, desde 2008, uma outra discussão sobre titulação: a da 
criação de um projeto de assentamento. Também esta não é uma discussão que envolve todas as famílias, pois o assentamento está localizado na gleba Bujaru e somente os moradores que ocupam as terras desta gleba, onde é proposto o assentamento, é que poderiam entrar nele ${ }^{56} \mathrm{O}$ assentamento é denominado Rio Bujaru, possui uma área de 8.283,9790 ha, onde existem parcelas de aproximadamente 50 há, e atende um número aproximado de 199 famílias (INCRA, 2008b), envolvendo inclusive famílias de comunidades que iriam se autodefinir quilombolas, mas que, com a chegada da proposta do assentamento, preferiram aceitá-lo e desistiram do processo de reconhecimento como remanescente de quilombo ${ }^{57}$.

Com o intuito de viabilizar a criação do Projeto de Assentamento o INCRA já realizou o Relatório de Viabilidade Ambiental do projeto para ser encaminhado à Secretaria de Estado e Meio Ambiente do Estado do Pará (SEMA) para análise. Trata-se da concessão da Licença Prévia exigida para a criação de projeto de assentamento em área de reforma agrária (INCRA, 2008b). Na verdade a área é de regularização fundiária e não reforma agrária. De acordo com Oliveira (2009), as diferenças entre estas duas ações são: a regularização fundiária é o reconhecimento do direito das famílias já existentes nas áreas objeto da ação, enquanto que a reforma agrária são os assentamentos decorrentes de ações desapropriatórias de grandes propriedades improdutivas, compra de terra e retomada de terras públicas griladas. Diferenciação importante, principalmente quando queremos obter os números da reforma agrária no Brasil.

Apesar de algumas poucas famílias terem participado das reuniões sobre o assentamento, que ocorriam em uma comunidade vizinha, não chegaram a entrar no assentamento, pois a área do mesmo não alcançava suas posses. Nesse ínterim uma outra ação de regularização fundiária apareceu na comunidade em 2009. Técnicos do MDA chegaram com a proposta de regularizar as terras por meio do programa Terra Legal Amazônia. Com o apoio da prefeitura, EMATER, INCRA e STR, os técnicos estão no município desde outubro de 2009 realizando os cadastros das famílias posseiras. Cerca de 24 famílias em Nova Esperança realizaram o cadastro no Sistema Terra Legal (SISTERLEG), somando uma área de 908 ha (BRASIL, 2010). De acordo com a Lei $n^{\circ} 11.952 / 2009$, o prazo é, a partir do cadastramento, de 120 dias para a entrega do título se não existir contestação sobre a ocupação do imóvel ou litígio judicial, mas até setembro de 2010 as famílias ainda não haviam recebido a titulação.

\footnotetext{
${ }^{56}$ A comunidade está em terras das glebas Bujaru e Araxiteua.

${ }^{57}$ Nestes casos, só um estudo nestas comunidades permitiria entender as razões dessa mudança.
} 
Com a ação do Terra Legal, novamente surgiram problemas com a ARQUINEC, que precisou intervir na ação do MDA, pois a equipe entrou em comunidades já certificadas pela FCP. Em uma reunião no STR, a equipe reconheceu que precisava verificar quais eram as comunidades quilombolas no município e chamar a ARQUINEC para suas próximas reuniões, para que não ocorresse mais uma vez a entrada da equipe onde não era de sua responsabilidade a regularização, como é o caso do território quilombola

Nova Esperança expressa o conflito entre as diversas propostas de regularização fundiária do governo federal, assim como o conflito entre os diversos sujeitos que as defendem, segundo o seu entendimento sobre a melhor forma de regularizar. 


\section{OS TERRITÓRIOS EM ESTUDO}

\subsection{O processo de formação territorial: do rio à estrada}

O rio Bujaru, afluente da margem esquerda do rio Guamá, atravessa o território do atual município de Bujaru em mais de $100 \mathrm{~km}$ em direção ao sul do estado, adentrando no município de Concórdia do Pará, até o sul do município. É à margem deste rio e de seus afluentes que se localizam as comunidades estudadas: Campo Verde, Jutaí-Mirim e Nova Esperança, sendo esta última aquela mais distante. O Bujaru é um rio dotado de muitos afluentes, sendo os mais importantes os igarapés ${ }^{58}$ Cravo e Jutaí, os quais, por sua vez, possuem inúmeros outros afluentes que conformam áreas de igapó, de várzea e de terrafirme ${ }^{59}$.

De acordo com a situação das posses das vinte Cartas de Data de Sesmarias concedidas entre 1724 e 1824 nas margens do rio, todo o rio Bujaru foi ocupado até o final do século XVIII, sendo a maior parte das Cartas concedidas na primeira metade do século XVIII (CASTRO, 2003).

Analisando os censos de 1778 e 1803, Castro (2003) verifica que houve um aumento da população escrava que estava localizada em fazendas e engenhos do Bujaru, o que revela uma provável ocupação das terras muito maior do que seria permitido pelas vinte Cartas. É isto que faz com que a autora levante a hipótese de que

[...] as concessões representariam apenas uma parte das terras efetivamente declaradas como pertencentes aos sesmeiros, indicando uma apropriação privada de terras públicas fora do sistema sesmarial, mas finalmente por ele legitimada na medida em que poderia ter um documento oficial como aval à sua instalação (CASTRO, 2003, p. 2).

Pelas Cartas de Sesmarias depreende-se que neste território havia posseiros há muito tempo. Estes viviam "sob mecanismos de apossamento primário, ou posses recebidas por

\footnotetext{
${ }^{58}$ Igarapé: Rio pequeno que tem as mesmas características dos grandes e que é geralmente navegável. Os maiores denominam-se igarapés-açus e os menores, igarapés-mirins (FERREIRA, 2004).

${ }^{59}$ Igapó: área constantemente inundada e pantanosa. As áreas de várzea se estendem ao longo dos grandes rios e são inundadas diariamente pela maré ou anualmente pelas cheias. Terra firme são as áreas mais altas, jamais inundadas pelas enchentes dos rios (BRANCO, 1989).
} 
heranças, desenvolvendo uma agricultura de roças, lavouras de gêneros diversos, com plantios de cacau, tabaco e cana-de-açúcar" (CASTRO, 2003, p.15). Algodão e criação de algumas cabeças de gado também figuravam entre as atividades desenvolvidas, mas a que predominava era o cultivo da mandioca (CASTRO, 2003).

Estavam presentes na região grandes e médios proprietários, pequenos sesmeiros, sitiantes sem terra, quilombolas e índios destribalizados. O acesso à terra era um privilégio e estava relacionado, não de forma restrita, a um sistema de poder e hierarquia de que a Igreja também fazia parte (CASTRO, 2003).

A partir de seus estudos, Castro considera que nas terras do rio Bujaru conformou-se

[...] uma estrutura fundiária que repousa sobre algumas poucas grandes propriedades em uma maioria de sitiantes que se dedica a atividades agroextrativas. Os apossamentos oficiais pela via das sesmarias e do apossamento primário através de mecanismos da informalidade, se confundem. É possível pensar que o apossamento da terra se fez mais através de mecanismos ilegais do que legitimados pelo sistema sesmarial (CASTRO, 2003 p.33).

Para Castro, no século XVIII ocorreu a formação de um campesinato como conseqüência da expansão da agricultura. Este foi um movimento que contribuiu para a consolidação da colonização portuguesa na província. Todavia, paralelo a este processo, tivemos a concentração de terras que foi bastante perceptível na concessão de várias Cartas de Data de Sesmarias ao mesmo sesmeiro, além da incorporação ilícita de terras públicas (CASTRO, 2003).

No último quartel do século XVIII verificou-se um declínio tanto na concessão de sesmarias quanto na capacidade dos senhores para adquirir novos escravos. Este declínio contribuiu para o processo de mobilização e fuga dos escravos, constituição de quilombos, surgimento de revoltas e levantes em fazendas que envolviam negros escravos e índios destribalizados, cafuzos e alguns sitiantes que "[...] viriam a definir, em parte, a conformação atual dos apossamentos de terras por parte de grupos de população de origem africana que chega até a atualidade no município de Bujaru" (CASTRO, 2003, p. 12) e também em Concórdia do Pará.

As terras vizinhas ao rio Bujaru, banhadas pelo rio Moju, mostravam um perfil de grandes e médias propriedades ocupadas com o cultivo da cana-de-açúcar, onde existiam também engenhos e engenhocas para a fabricação do açúcar e da aguardente. Esta atividade também se desenvolveu nos rios Acará e no Capim, rios que correm paralelamente ao rio Bujaru (CASTRO, 2003). Já as terras do rio Guamá, onde deságua o rio Bujaru, e do rio Capim, mostraram-se férteis para o cultivo da cana-de-açúcar e do cacau, mas não só disso 
viviam seus moradores. Produtos como castanha-do-pará, óleo de copaíba, salsaparrilha ${ }^{60}$ e madeira também abasteciam o mercado regional, além das roças de mandioca, milho, arroz e verduras. Além destes, o tabaco e o café foram cultivados, porém em pequenas quantidades (CASTRO, 2003).

Ainda em relação às povoações criadas neste processo de ocupação, no século XVIII, encontramos a freguesia Sant'Anna do Rio Bujaru (atual Vila Sant'Anna) (Foto 8).

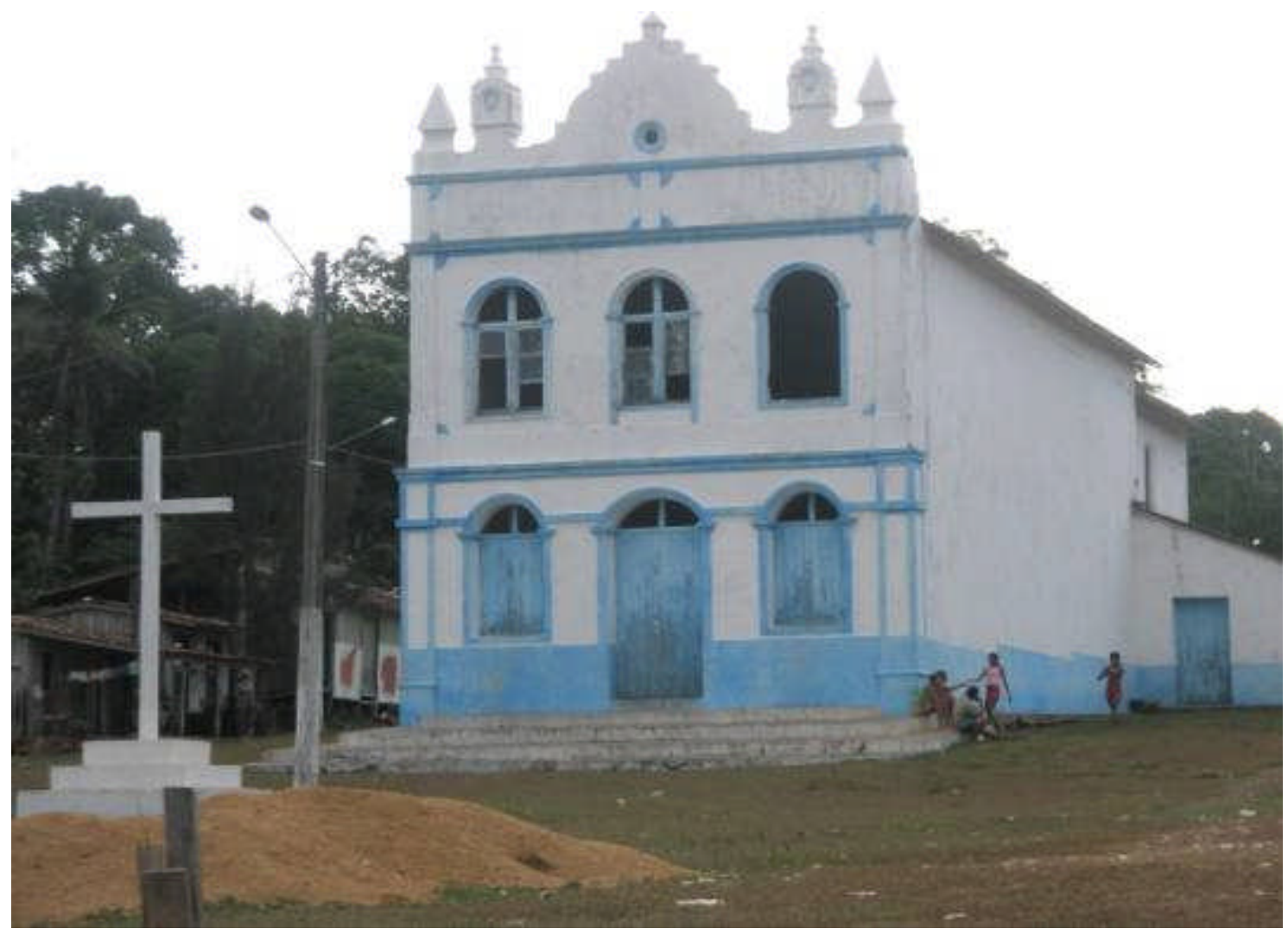

Foto 8: Igreja de Sant'Anna, na Vila Sant'Anna, município de Bujaru/PA, que data do século XVIII (foto da autora em out./2008).

A freguesia Sant'Anna do Rio Bujaru era uma das nove freguesias campestres organizadas a partir de Belém. Ainda hoje localiza-se à margem direita do rio Bujaru, a

${ }^{60}$ A salsaparrilha é um arbusto que ocorre em regiões temperadas e principalmente nas tropicais. Suas folhas e frutos são utilizados como condimento na alimentação e suas fibras na área de construção. Sua raiz possui propriedades depurativa, diurética, diaforética, aperiente, eupéptica, emoliente, expectorante, antileprosa, miotônica e sudorífica, sendo utilizada no tratamento de gripes, febres, resfriados, sífilis, psoríase, dermatoses, eczemas, verrugas, furúnculos, gota, reumatismo, artritismo e afecções vesiculares e renais (MEDEIROS; SENNA-VALLE; ANDREATA, 2007). 
aproximadamente $25 \mathrm{~km}$ de sua foz no rio Guamá. Era para esta vila que convergia, nos séculos XVIII e XIX, a produção de sesmeiros e sitiantes que residiam às margens do rio Bujaru e de seus afluentes, como os igarapés Jutaí, Ipanema, Curuperé, João e Cravo. A produção era levada em canoas de pequeno e médio porte para a freguesia de Sant'Anna e, a partir dela, entrava no circuito do comércio vinculado a Belém (CASTRO, 2003).

A vizinhança da freguesia Sant'Anna do Rio Bujaru com as freguesias do rio Capim, do Rio Acará e a freguesia São Domingos da Boa Vista "permitia manter um circuito de comunicação entre as fazendas, engenhos e engenhocas e cobrir dificuldades decorrentes da distância e de transporte" (CASTRO, 2003, p. 27).

Sobre a existência de engenhos, existem várias referências na bacia do rio Bujaru. A produção destes engenhos dependia do trabalho escravo e dos sitiantes. Com o passar do tempo, seus donos abandonaram as terras, restando somente algumas ruínas. Os sitiantes ficaram e continuaram a abrir roças para o plantio da mandioca, milho, feijão e arroz, a caçar nas matas locais e a pescar nos igarapés e no rio (ARQUINEC; ARQUIOB, 2006).

Além de engenhos também temos registros de mocambos, como o Mocambo Cobruto, que teria sido formado por negros que fugiram do Convento dos Padres Carmelitas no rio Bujaru, e o Quilombo da Fazenda Estrela ou Pernambuco, conhecido por estar nas Terras de Nossa Senhora (CASTRO, 2003). Também nesta região tivemos a formação de quilombos nas cabeceiras dos igarapés Cravo, Dona, João e Curuperé (ARQUINEC; ARQUIOB, 2006).

Muitos relatos de fugas e capturas se registraram no rio Bujaru. Estas fugas interessavam principalmente os proprietários e posseiros que não possuíam escravos. Para ambos, a existência de homens livres que pudessem vir trabalhar em suas propriedades por alguma forma de pagamento era essencial para seus empreendimentos na produção de cacau, cana-de-açúcar, nos engenhos, na navegação e na construção (CASTRO, 2003).

Os dados encontrados por Castro não permitiram avaliar o tamanho dos quilombos em Bujaru e se conseguiram permanecer no tempo enquanto quilombos ou se refizeram outras formas coletivas de vida a partir de grupos familiares. Porém, de acordo com a autora, o "potencial dos roçados e da produção de farinha, de castanha, de peixe e outros gêneros por eles produzidos e levados para Belém, nos permitem concluir pela importância numérica dessas povoações" (CASTRO, 2003, p. 68).

Não é possível saber qual o número de escravos existentes na freguesia de Sant'Anna do Rio Bujaru em 1765, pois o levantamento da população realizado naquele ano não discrimina, informando apenas a existência de 292 habitantes. Apenas em 1823 é que este número aparece discriminado na contagem da população: 799 livres, 915 escravos, 
totalizando 1.714 habitantes. Este número é bem menor que o de suas freguesias vizinhas como Acará, Moju, Capim, Igarapé Mirim e Abaeté. Porém contribuiu significativamente para a economia no rio, para a sua ocupação e para a conformação do território das comunidades existentes atualmente nas margens do rio.

Segundo Castro (2003), a proximidade dessas localidades a Belém, influenciava o maior controle da produção, estando as atividades agrícolas mais integradas ao mercado interno e aos objetivos do comércio de importação e exportação.

Até a década de 1960, estas antigas freguesias, muitas já transformadas em município, tinham os rios como os principais meios de circulação. Com a construção da Belém-Brasília uma nova dinâmica se instala no Pará, instaurando um novo meio de circulação, a estrada, que propicia também um novo dinamismo econômico, político, social e territorial.

Um exemplo da junção da dinâmica do rio com a dinâmica da estrada é o município onde estão localizadas as comunidades estudadas: o município de Concórdia do Pará, que está localizado na Microrregião de Tomé-Açu, na Mesorregião Nordeste Paraense, a 150 km de Belém. Limita-se ao norte com o município de Bujaru; a leste com o município de São Domingos do Capim; ao sul com o município de Tomé-Açu; a oeste com os municípios de Acará e Bujaru (PARÁ, 2007d). O município possui 21.422 habitantes, em uma área de 690,94 km² (IBGE, 2009). Tem como vias de acesso a BR 316, PA 140, PA 252.

Este município tem sua história ligada às freguesias de Sant'Anna do Rio Bujaru e São Domingos da Boa Vista, no rio Capim. Crônicas do século XVIII registram a formação, pelos colonizadores, do núcleo de São Domingos da Boa Vista no rio Capim, reconhecido como Freguesia em 1758 por Francisco Xavier de Mendonça Furtado. Esta freguesia localizava-se na confluência de rios bastante navegáveis, o que favoreceu uma intensa atividade econômica e comercial. No ano de 1833, esta freguesia passou a fazer parte do município de Belém (PARÁ, 2008a).

Com o advento da República, o governo provisório do estado do Pará promulgou o decreto legislativo $\mathrm{n}^{\circ} 236$, em 9 de dezembro de 1890, mediante o qual a freguesia foi elevada à categoria de vila, e pelo decreto estadual $n^{\circ} 237$, da mesma data, ficou constituído como município. Pelo decreto estadual $\mathrm{n}^{\circ} 720$, de 19 de agosto de 1932, o município passou a se denominar São Domingos do Capim (PARÁ, 2008a).

Posteriormente, em 1943, com a nova divisão territorial do estado do Pará, a área territorial desse município foi dividida para a criação de São Miguel do Guamá e de Bujaru. 
Este último município era, desde 1758, distrito de São Domingos do Capim ${ }^{61}$ (PARÁ, 2008a). É no município de Bujaru que se encontra hoje a antiga Freguesia Rural de Sant'Anna do Rio Bujaru, nas margens do rio Bujaru, com mais de 300 anos (CASTRO, 2003). De acordo com Castro (2003) os primeiros moradores das margens desse rio foram inicialmente os índios. Posteriormente vieram os sitiantes, cafuzos e colonos portugueses que solicitaram Cartas de Data de Sesmarias desde o início do século XVIII, indicando seus servos e escravos.

Entre os anos de 1969 e 1970, ao sul do então município de Bujaru surgiu um povoado em função da construção da antiga Rodovia PA 01, atual PA 252, e da Rodovia PA 140 (paralela ao rio Bujaru) que ligava o povoado à sede do município de Bujaru. Por estar localizado no cruzamento das duas rodovias, o povoado recebeu o nome de "Quatro Bocas". Uma das primeiras atividades desenvolvidas foi a extração de madeira por meio das primeiras serrarias instaladas na década de 1970 (PARÁ, 2007d).

A pimenta-do-reino e a pecuária tiveram uma contribuição significativa para o crescimento do povoado (FERREIRA, 2003). No entanto, a exploração de recursos florestais, com destaque para a exploração de madeira de lei, foi o fator determinante para o seu crescimento demográfico e econômico, atraindo populações oriundas de municípios próximos (PARÁ, 2007d), como Garrafão do Norte, Capitão Poço e Irituia (FERREIRA, 2003) e de outras regiões do Brasil, principalmente do Nordeste. O desenvolvimento destas atividades, somado à possibilidade de ligação rodoviária para Bujaru $(72 \mathrm{Km})$, Acará $(24 \mathrm{Km})$, Mãe do Rio $(48 \mathrm{Km})$ e Tomé-Açu $(52 \mathrm{Km})$ foram fatores fundamentais para o crescimento da localidade de Quatro Bocas, onde ficou situado o distrito de Vila Concórdia e posteriormente a sede do município de Concórdia do Pará (PARÁ, 2007d) (Mapa 1).

Nos anos 1980, com o predomínio de um modelo de gestão baseado no princípio da divisão territorial como forma de obter eficiência e governabilidade, houve um processo de desmembramento, criando-se no Pará inúmeros novos municípios, dentre os quais está Concórdia do Pará (CASTRO, 2003). Em 24 de abril de 1988 um plebiscito junto à população resultou em $98 \%$ de apoio ao projeto de emancipação do povoado de Vila Concórdia

\footnotetext{
${ }^{61}$ No ano de 1955, outra parte de São Domingos do Capim foi desmembrada para possibilitar o surgimento do município Santana do Capim, fato que, em 1956, foi anulado. Outros desmembramentos ocorreram em 1965 para dar origem ao município de Paragominas; em 1982 para a criação do município de Rondom do Pará, e em 1991 para originar os municípios de Ipixuna do Pará e Aurora do Pará. Conta atualmente somente com o distritosede São Domingos do Capim (PARÁ, 2008a).
} 
(FERREIRA, 2003). Mediante a promulgação da Lei $\mathrm{n}^{\circ} 5.442^{62}$, de 10 de maio deste mesmo ano, Vila Concórdia foi reconhecida como município e passou a denominar-se Concórdia do Pará (PARÁ, 2007d).

Para a criação do novo município, o território dos municípios de Bujaru e de São Domingos do Capim precisaram ser redivididos. O traçado da divisão territorial não obedeceu a critérios da organização social e econômica de sua população, mas a prerrogativas de ordem políticas decorrentes do jogo de atores e de interesses por parte das elites locais e regionais (CASTRO, 2003). Na época de sua emancipação política e administrativa, Concórdia do Pará apresentava algumas povoações em seu território, embora não fossem consideradas distritos: povoado do km 35 da PA 140, trecho em direção a Bujaru, vila Cravo, Jutaí, Galho, Arapiranga, povoado do $\mathrm{Km} 8$, Vila Patrimônio e a colônia Colatina, que se destacava por sua produção de mandioca (FERREIRA, 2003; IBGE, 2009).

Como atividade econômica do município, encontramos na lavoura temporária um grande destaque, em especial para a mandioca e em seguida para o milho, feijão, arroz e melancia; na lavoura permanente, há um grande destaque para a pimenta-do-reino, seguida do coco-da-baia, dendê, cacau, maracujá, urucum, banana e limão; na pecuária, destacam-se os rebanhos de bovinos, mas encontramos também suínos, eqüinos, caprinos, ovinos, muares, bubalinos, asininos; também se destaca a criação de aves; no extrativismo vegetal e na silvicultura destacam-se a extração do açaí (fruto), madeira em tora, lenha e carvão vegetal (IBGE, 2006), e a pesca, embora menos significativa (INCRA, 2005).

Outra atividade que está ganhando atenção tanto de camponeses como da administração municipal é o cultivo do dendê. Esta atividade já era desenvolvida pela empresa Dendê Tauá e, desde 2007, a empresa Biovale, inicialmente Biopalma, vem comprado terras de fazendeiros e camponeses para a implantação do cultivo.

A Biopalma da Amazônia S/A, Reflorestamento, Indústria e Comércio é uma empresa do grupo MSP constituída em 2007. O Grupo MSP atua nos setores de extração mineral, serviços essenciais e de infra-estrutura e indústria alimentícia (por meio da Biopalma). No dia 22 de maio de 2009, o governo federal deu um parecer técnico favorável ao consórcio formado pela Biopalma e a Companhia Vale do Rio Doce para a construção, operação e manutenção de um complexo de produção de óleo de palma. Neste consórcio a CVRD terá participação de $41 \%$ e a Biopalma de 59\% (BRASIL, 2009a). A empresa passa então a denominar-se Biovale.

\footnotetext{
${ }^{62}$ Há também registros de que a Lei é de $n^{\circ} 5.441$.
} 
Concórdia do Pará possui uma estrutura fundiária marcada por uma concentração de pequenas e médias propriedades. Atualmente existem quatro Projetos de Assentamento criados pelo INCRA: Nova Santa Maria, Inácia (INCRA, 2005), Jutaí-Mirim (INCRA, 2008a) e Rio Bujaru (INCRA, 2008b). Destes assentamentos, somente o Nova Santa Maria e o Inácia foram criados a partir de movimentos de ocupação de fazendas do município, os demais são objeto de regularização fundiária. Além destes assentamentos, existem nove comunidades que pleiteiam a regularização de suas terras como remanescentes das comunidades dos quilombos $^{63}$. Este processo está sendo encaminhado pela Associação de Remanescentes de Quilombos Nova Esperança de Concórdia do Pará (ARQUINEC). Outra forma que os camponeses de Concórdia do Pará buscam regularizar suas terras está sendo por meio do Programa Terra Legal. Este é um programa do governo federal que objetiva regularizar as terras na Amazônia até 15 módulos fiscais.

O estudo das comunidades Jutaí-Mirim, Campo Verde e Nova Esperança (Mapa 1) para a compreensão sobre os caminhos da regularização fundiária no Pará, busca elucidar essa diversidade de formas de regularização das terras e se ela forja ou não uma diversidade também de configuração territorial na região. Busca-se também compreender como a diversidade de relações entre comunidade e outros grupos a elas externos acabam por intervir no processo de escolha dos camponeses sobre a melhor forma de regularizar suas terras.

\footnotetext{
${ }^{63}$ Nova Esperança (cadastrada como Velho Expedito), Cravo, Campo Verde, Timboteua Cravo, Perpétuo Socorro, Santo Antonio, Dona, Curuperé e Ipanema
} 


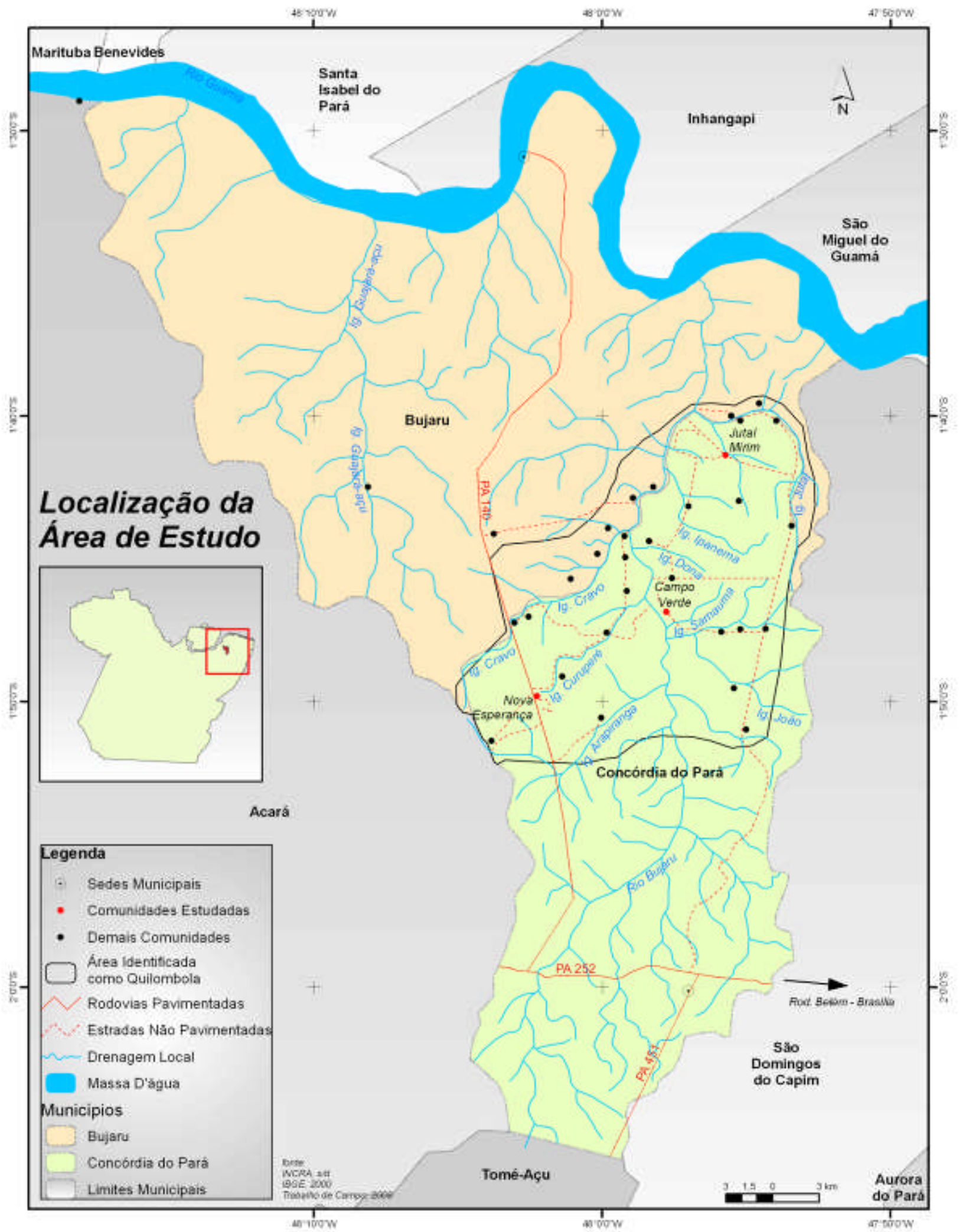

Mapa 1: Localização da área identificada como pertencente a remanescentes das comunidades dos quilombos e das comunidades em estudo.

Elaborador: Rafael Honório, 2009. 
Ao tratar da formação territorial destas comunidades, percebemos nitidamente dois momentos da história da Amazônia. O primeiro marcado por intenso processo de ocupação em que o rio era a via privilegiada de acesso às terras e todos os demais recursos que a região pode oferecer. O segundo marcado pela força da rodovia que, no seu rastro, traz a propaganda do desenvolvimento e do progresso. Ao primeiro momento de ocupação remontam as história de Campo Verde e Jutaí-Mirim, e ao segundo, a história de Nova Esperança. O que as três têm em comum então? A necessidade de seus moradores, independente do momento histórico em que foram formadas, de manter a terra que com o fruto do trabalho familiar conquistaram.

\subsection{Três comunidades e um modo de vida: $o$ camponês}

\subsubsection{Campo Verde}

Campo Verde está localizada às margens do rio Bujaru, tendo como vias de acesso a estrada vicinal Transjutaí e o rio Bujaru. Dista cerca de $39 \mathrm{~km}$ da sede do município de Concórdia do Pará e faz limite com as comunidades Galho (ao Leste), assentamento Santa Maria (ao Norte) e Curuperé (ao Oeste) e uma fazendas (ao Sul). Possui 43 famílias, num total de aproximadamente 237 pessoas em uma área de 1.185,5124 há (Mapa 1). As famílias estão dispostas em um território recortado pelo rio Bujaru (de aproximadamente $25 \mathrm{~m}$ de largura), por diversos afluentes deste rio, por duas vicinais e inúmeros caminhos internos. A comunidade possui um núcleo, chamado de Arraial, que é uma área de patrimônio da comunidade, documentada em nome da igreja, e onde ficam localizados a escola; a igreja, erguida em homenagem a São Tomé, padroeiro da comunidade; um cruzeiro bem em frente à igreja; o salão paroquial; a casa das mães ${ }^{64}$, construída pelo movimento de mulheres da comunidade (originalmente Clube das Mães) e algumas casas da família que doou a área para a igreja (Foto 9).

\footnotetext{
${ }^{64}$ A casa das mães é uma casa construída pelo grupo de mães da comunidade para a realização de reuniões e qualquer outra atividade planejada pelo grupo.
} 


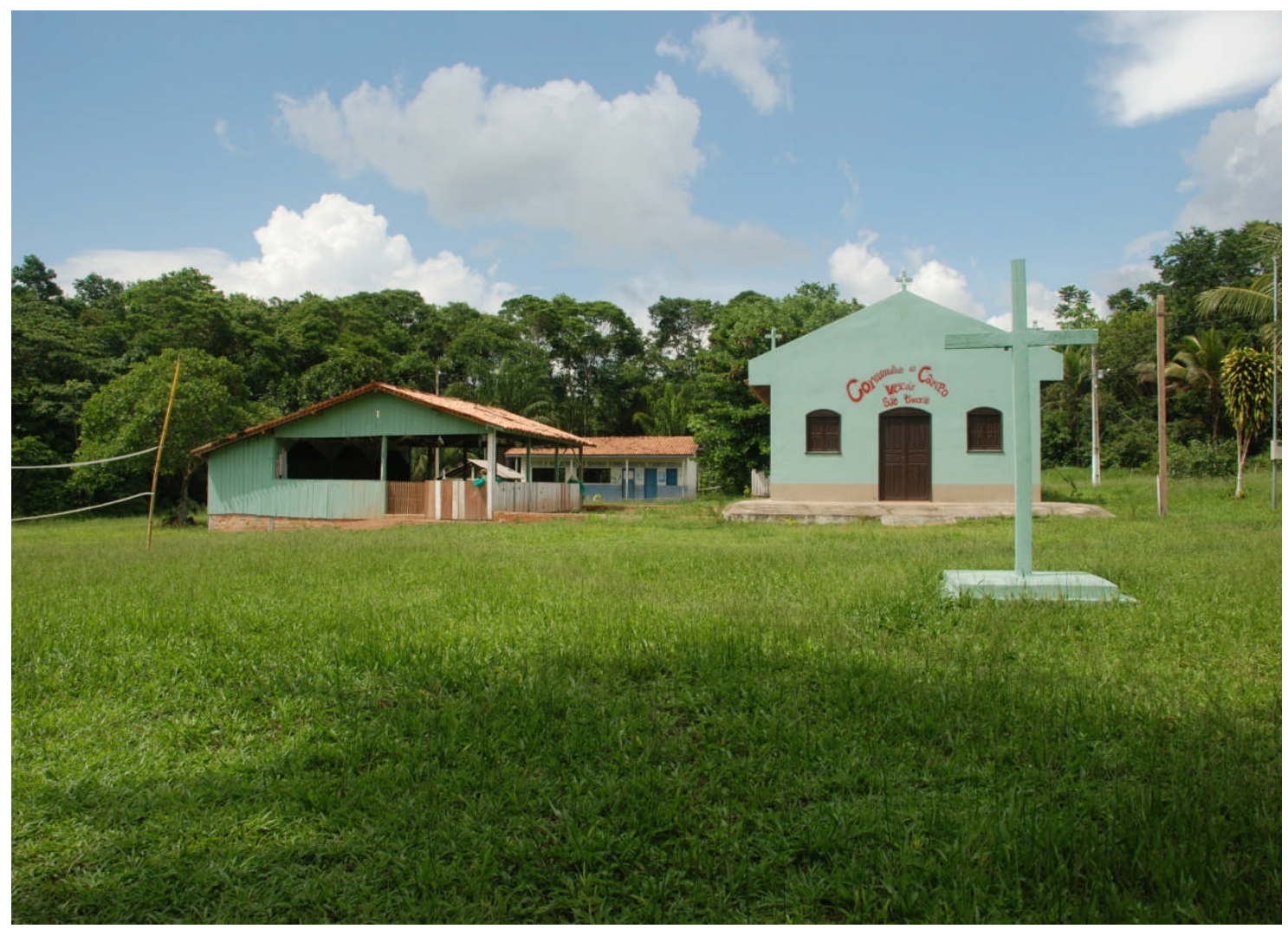

Foto 9: Arraial do Campo Verde onde vemos, da esquerda para a direita, o salão paroquial, a escola, a casa das mães e a igreja. Por trás da escola e da casa de mães existe uma estrada vicinal que para a esquerda vai para o assentamento Santa Maria e para a direita para a estrada vicinal Transjutaí (Valéria de Marcos em jan./2010).

Até 2005, o território de Campo Verde compreendia somente as terras da margem direita do rio Bujaru, onde estavam localizadas cerca de 34 famílias. As famílias que moram na margem esquerda do rio, oito, faziam parte de uma outra comunidade, denominada de Curuperé. No momento da demarcação das terras para titular a comunidade como remanescente de quilombo, as terras destas oito famílias foram incorporadas às da comunidade Campo Verde. Isto ocorreu em função da relação que estes moradores têm com os moradores da margem direita do rio. São relações de parentesco e de vizinhança que são mais fortes do que as relações que tinham com os demais moradores da comunidade Curuperé.

A religião tem sido um elemento de grande importância nesta proximidade, pois são os membros da Comunidade Eclesial de Base (CEB) de Campo Verde que visitam estas famílias, realizando encontros dos grupos de evangelização, novenas e catequese. Esta proximidade também ocorreu no processo de mobilização para a regularização das terras, pois eram as lideranças de Campo Verde que se reuniam com as famílias, sendo as mesmas sempre 
convocadas para qualquer atividade da Associação de Remanescentes de Quilombo Nova Esperança de Concórdia do Pará (ARQUINEC).

Em Campo Verde existem famílias que já residem a mais tempo e outras que chegaram na década de 1950. O senhor João Ferreira, de 75 anos, é um destes moradores mais antigos. Suas terras foram herdadas de sua mãe, que comprou de um senhor chamado Pedro Cardoso Mendes que, junto com um irmão chamado Fileto e irmãs, possuía terras onde é hoje parte de Campo Verde. O seu avô também era de lá, mas sua avó era da comunidade Arapiranga, mais ao alto do rio Bujaru.

O senhor João conta um pouco como era a vida quando era mais jovem:

[...] ah! nesse tempo era fácil pra vivé a vida [...] tinha caça, muita caça, peixe. A gente não se preocupava muito com comércio [...] paca, tatu, viado, cutia. [...] agora tá vasqueiro [...] a gente vive da taberna agora [...] vai pro rio pra matá peixe $[. .$.$] , mata só uns quatrozinho [...] nessa época [...] matava$ uns montão de peixe [...] tudo que é marca, Traira, Acará [...] (informação pessoal $)^{65}$.

Além da caça e da pesca, realizavam plantio de açaí, abacate, cupuaçu, pupunha, castanha; criavam pato, galinha e porco; faziam roça de arroz, milho, feijão, maniva, banana, mas tinha que ser feita no fundo do terreno onde a água do rio Bujaru não chegasse à época das chuvas. Senhor João lembra que quando uma família precisava, muitos ajudavam, chegavam a plantar uma tarefa $\left(25 \mathrm{~m}^{2}\right)$ de roça com a ajuda dos vizinhos em um dia. Hoje em dia, segundo ele, essa prática quase não se realiza mais.

Outra moradora antiga é a senhora Sebastiana Cardoso da Conceição, de 74 anos. Ela é neta do senhor Pedro Cardoso Mendes, mas não mora em terras deixadas pelo avô, que foi vendendo ao longo do tempo. Mora nas mesmas terras de seu João, pois é sua cunhada.

Segundo a senhora Sebastiana, da floresta eles coletavam o óleo da andiroba; "leite" (látex) da massaranduba para fazer mingau de arroz; "leite" da seringueira; óleo de copaíba; "leite" do Amapá66, que é bom para a gripe e para engordar, desde que bem temperado com canela e cravo, explica ela. A comercialização destes vários produtos, que eram transportados na canoa, era realizada com os comerciantes que ficavam na foz do igarapé Cravo, na foz do igarapé João e na vila Sant'Anna, às margens do rio Bujaru.

Segundo o senhor João, a relação com o comerciante ocorria principalmente nos períodos de safra:

\footnotetext{
${ }^{65}$ João do Amaral Ferreira, entrevista à autora em out./2008.

${ }^{66}$ Árvore da família das apocináceas (Parahancornia amapa), de madeira útil, e cuja casca, amarga, exsuda látex medicinal, de aplicação no tratamento da asma, bronquite e afecções pulmonares, tendo seu uso externo poder resolutivo e cicatrizante de cortes e feridas (FERREIRA, 2004).
} 
[...] nessa época a gente comprava [...] do comerciante por safra [...] pagava conta de uma safra né, a gente ficava comprando o ano todo só ia pagava no outro ano de novo a conta, aí a gente ia comprando, comprando no outro ano, na safra que a gente colhia arroz [...] levava lá e pagava essa conta velha e abria nova conta [pagava com] arroz, milho, aí ficava comprando fiado de novo o ano todo, e agora não mudou o negócio, agora vai comprar no comércio o prazo que ele dá é só oito dias [paga] com arroz, com farinha[...] eles compro o gênero, põe no barco e levo pra Belém pra vender [...] (informação pessoal) ${ }^{67}$.

Segundo a senhora Sebastiana

[...] eles [os comerciantes] que dão o preço pra gente, até agora ele que dão o preço, a gente leva o gênero da gente, mas a gente não tem direito de pedir o preço da gente eles que vão botá o preço, se pedi 10 rear ou cinco eles dão, a gente tem que pegá, não pode reclamar [...] Deus livre de reclamar capaz deles darem na gente $[\ldots]$, mas por aí tem marreteiro ${ }^{68}$ que compra farinha [...] (informação pessoal) ${ }^{69}$.

De acordo com o senhor João

[...] os produtos de hoje agora a gente não leva pra comerciante mais, marreteiro vem, compra e pede o valô dele [no passado] não tinha marreteiro, aí a marreiteiro vem, compra a farinha da gente, o gênero que ele quisé [...] (informação pessoal ${ }^{70}$ ).

O senhor Miguel também aponta outros moradores da mesma época que o senhor Pedro Cardoso: Adriano, Maria Marculina e Sérvo. Outros antigos moradores, mas que não residem mais em Campo Verde, são: senhor Veríssimo, senhora Clotilde e senhora Bernarda. As terras destas pessoas foram compradas pelo pai do senhor Miguel, presidente da comunidade, que chegou no fim da década de 1950. Depois das compras realizadas, o pai do senhor Miguel foi vendendo para os irmãos e para o próprio pai. O restante das terras foi dividido entre ele e os filhos, que eram seis, entre eles, o senhor Miguel, que junto com seus irmãos e sobrinhos, formam grande parte das famílias de Campo Verde (Foto 10).

\footnotetext{
${ }^{67}$ João do Amaral Ferreira, entrevista à autora em out./2008.

${ }^{68}$ Marreteiro é a designação dada aos comerciantes que vão de porta em porta em busca da produção das famílias para a compra.

${ }^{69}$ Sebastiana Cardoso da Conceição, entrevista à autora em out./2008.

${ }^{70}$ João do Amaral Ferreira, entrevista à autora em out./2008.
} 


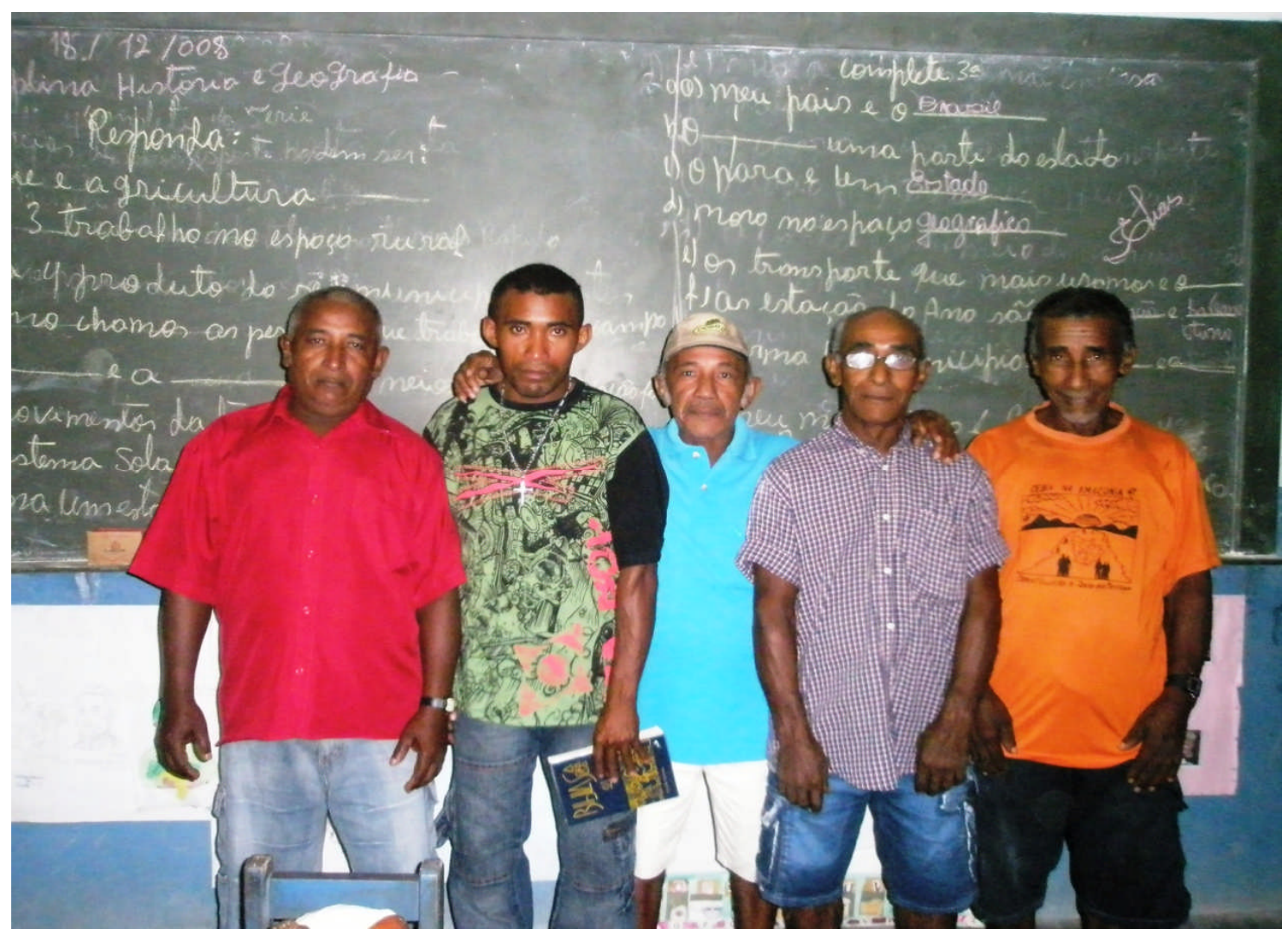

Foto 10: No centro está o senhor Miguel cercado pelo filho e irmãos, na comunidade Campo Verde, Concórdia do Pará (foto da autora em dez./2008).

Do outro lado do rio Bujaru, o senhor Tomé, de 72 anos, mora em terras herdadas de seu bisavô que demarcava o tamanho da propriedade "à cachimbada",71.

[...] o avô dela [da mãe dele] quando chegó pra cá, Bujaru era, tinha gente, mas nesse tempo a pessoa chegava, eles medio terra era uma tá de cachimbada, né. O cara ia só de canoa, enchia um cachimbo grande né, acendia, sentava na proa da canoa e sentava remo, sentava remo, sentava remo, quando terminasse aquela cachimbada é aqui o marco [...] (informação pessoal $)^{72}$.

Assim como o senhor João, o senhor Tomé afirma que antigamente a vida era melhor, ressaltando a fartura na caça e na pesca. Ele também fala de como funcionava a relação com os comerciantes locais

[...] tinha comércio aí [...] era comércio não era besteira, parecia em Belém sabe [...], tinha tudo. [...] era o Madico [...], no João igarapé era o Lima Amaral [...], aí era comércio forte que tinha sabe [...] e nesse tempo era bom pra lavoura, nós pouca farinha nós fazia, aqui, né, porque caia a mandioca. Nossa lavoura era banana [... ], o arroz, nos colhia muito arroz, dava arroz e o arroz dava dinheiro, não é como agora né, [...] o pessoal fazia a roça

\footnotetext{
${ }^{71}$ Cachimbada indicava o tempo que eles gastavam fumando o cachimbo.

72 Tomé Lopes de Oliveira, entrevista à autora em dez./2008.
} 
quando era esse tempo de fazer a roça, mês de agosto, o cara começava tirá fiado na taberna, tirava pra fazer roça [...] pra roçar, derruba, queimava, plantava, capinava, zelava, quando chegava mês de maio em diante começava apanhá o arroz, panhava arroz pra começar em maio, maio, junho, julho e tinha dia que ia terminar em agosto, muito arroz [... ] aí que quando o cara chegava levava arroz pra comércio, pagava toda conta, tirava dinheiro, ia passá festa de Santana fazia farra pra lá, antes disso ia pra Belém comprá calçado, roupa, né, e pra passá festa de Santana, se metia na farra pra lá, vinha de lá, aí que mês de agosto ia tirá o resto de arroz, esse que era já o dele, o lucro dele. Hoje em dia se os cara fazé uma roça e plantar arroz, além de que dá pouco, se o cara tirá fiado no comércio só pra fazé colheita, não dá, [...] o arroz não dá pra pagá. [...] nesse tempo pra levar arroz pro comércio, tinha gente que antes de chegar no comércio metia o casco no fundo pro arroz pesá né, e hoje em dia se o cara colhe um pouquinho tem que botá no sol três dias pra secá, tem que espaná o arroz pra podé levá, chegá lá vende uma mixaria e não dá pra coisa nenhuma. Eu não sei porque da carece secá arroz, eu não sei porque tem essa coisa, [...] [antes] não secava, nos levava arroz, panhava hoje, pisava amanhã, já levava pra taberna o arroz com todo leite, todo verde o arroz, e não tinha nada dessa coisa de tá secando arroz [...] mas não dá pra nada diz que 10 rear um saco de sessenta quilo, já penso? antes compra o arroz já pronto de que o cara fazé roça, se o cara fazé roça pra plantar arroz só fazé só pra ele come né, mas que prá vendé, ninguém interessa comprá [...] (informação pessoal) ${ }^{73}$.

O senhor Tomé relata que às vezes o marreteiro ia buscar a banana na casa deles. Apesar de no passado a lavoura ter sido boa, o transporte era péssimo. Quando algum morador adoecia, tinha que ir para Belém em barco lotado, que parava em cada porto que existia no rio Bujaru. Agora com as estradas que passaram a ser construídas a partir da década de 1970, ficou muito melhor e rápido (Foto 11). O senhor João lembra que no inverno demoravam oito dias para ir e vir de Belém, e no verão quatro dias. Enquanto iam com a canoa no rio Bujaru, utilizavam uma vara (chamavam remo de falha) e quando chegavam ao rio Guamá colocavam a vela na canoa. Para os moradores irem à cidade de Bujaru, dependendo da época, eram três dias para ir e voltar. Segundo ele e a senhora Sebastiana, hoje em dia está melhor, porque eles saem pela manhã da comunidade para irem à cidade de Concórdia do Pará e meio-dia já estão de volta.

\footnotetext{
${ }^{73}$ Tomé Lopes de Oliveira, entrevista à autora em dez./2008.
} 


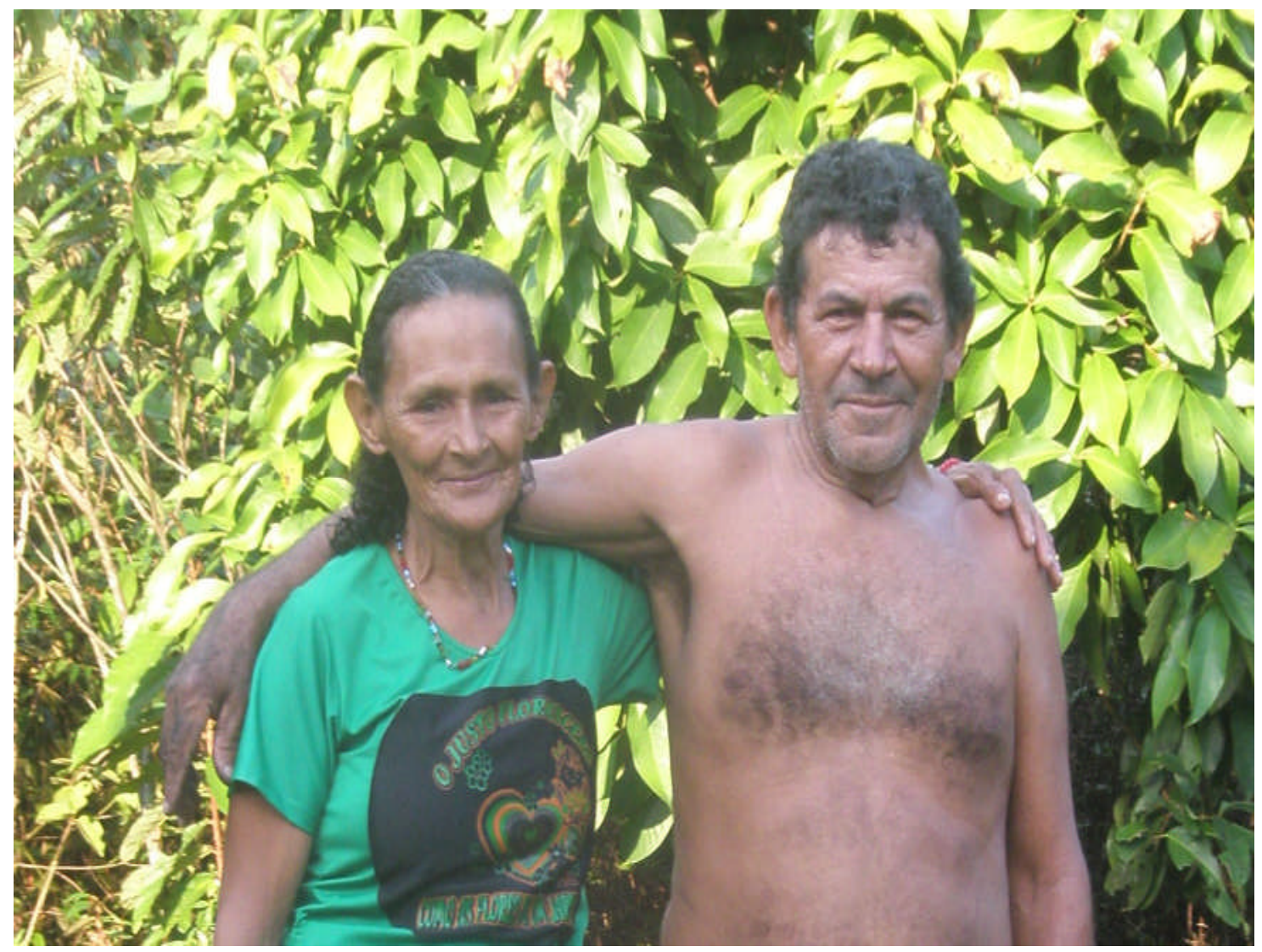

Foto 11: Senhor Tomé e sua esposa a senhora Camila, na comunidade Campo Verde, Concórdia do Pará (foto da autora em dez./2009).

Os moradores relatam que com o tempo foram sendo criadas as fazendas. Atualmente, ao lado do senhor Tomé existe uma fazenda em terras que eram de sua família e que foram vendidas ao um senhor chamado Ricardo. Isto deixa o senhor Tomé apreensivo, principalmente por causa da cerca que este fazendeiro vai construir. Isto porque o caminho do seu retiro ${ }^{74}$ ficou dentro da fazenda, mas o fazendeiro prometeu que iria respeitar. Do outro lado do rio, em frente à propriedade do senhor Tomé, também tem outra fazenda de um senhor chamado Quésio, mas segundo ele, este fazendeiro não tem como criar problema, pois fica do outro lado do rio. Esta fazenda se iniciou a partir de um antigo morador, que resolveu fazer uma pequena fazenda. Sr João relata que

[...] a fazenda começou a se criá de um tempo pra cá [...] depois que furaro esse negócio dessas estrada aí, aí contaminou de fazendeiro aí [...] o velho Madico tinha uns boizinho, mas não era fazenda, [...] aí contamino, eles vendero esse terreno aí. Já o Oscá, filho do Madico, aí boto, fez uma fazenda aí, ele mesmo, aí pego uns boi de metade aí, [...] só aquele boi búfalo, um

\footnotetext{
${ }^{74}$ Retiro é o local onde fica a casa de farinha.
} 
bom mucado de boi aí, aí não sei o que deu na cabeça dele e vendeu, vendeu não, deu o boi pro fazendeiro [...] (informação pessoal) ${ }^{75}$.

Além das estradas e fazendas, um outro elemento aparece como novo. Tanto senhor Tomé quanto o senhor João ressaltam o aumento do número de pessoas na comunidade, pelo fato dos filhos irem constituindo suas famílias e construindo suas casas, geralmente na posse dos pais.

Observando o dia-a-dia das famílias, não há como não perceber uma forma de organização existente que é bem estruturada e atuante: a Comunidade Eclesial de Base (CEB). Sua estrutura é composta por uma diretoria (presidente, secretário, tesoureiro e os coordenadores de diversas pastorais), pelas pastorais (juventude, catequese, dízimo) e pelos três grupos de evangelização que, semanalmente, reúnem-se na casa de um morador. É na reunião da diretoria, ou "das lideranças", como eles denominam, que são discutidos os problemas da comunidade, não só de caráter religioso, mas também político.

Os moradores realizam seus cultos todos os domingos pela manhã. O culto ocorre quando não existe a presença do padre. Neste caso, o celebrante pode ser qualquer membro da diretoria. Quando é o padre quem celebra, a celebração denomina-se Missa. Isto geralmente ocorre na festividade do santo padroeiro, no caso, São Tomé, santo de devoção de uma das famílias mais antigas.

De acordo com Teixeira (2005), o X Encontro Intereclesial das CEBs em Ilhéus, na Bahia, sinalizou a importância do aprofundamento da ministerialidade das CEBs. Em contraponto com a tendência centralizadora vigente na igreja católica, as CEBs apontam para uma igreja mais participativa e toda ministerial. As CEBs definem-se como comunidades celebrativas mas encontram-se ainda privadas da possibilidade eucarística. Os dados estatísticos apontam um índice de $70 \%$ de celebrações dominicais sem padre nas comunidades do Brasil.

A CEB de Campo Verde está vinculada à igreja de São Joaquim, no município de Bujaru, pertencente à Diocese de Abaetetuba. Esta Diocese possui uma grande atuação política junto aos movimentos sociais na região por meio da CPT Guajarina ${ }^{76}$. É por meio dos

\footnotetext{
${ }^{75}$ João do Amaral Ferreira, entrevista à autora em out./2008.

76 A prelazia de Abaeté do Tocantins foi criada em 25/11/1961, desmembrada da Arquidiocese de Belém do Pará. Foi confiada pela Santa Sé aos cuidados da Sociedade de São Francisco Xavier para as Missões Estrangeiras. Em 1981 foi elevada a Diocese, passando a denominar-se Diocese de Abaetetuba, abrangendo atualmente os municípios de Abaetetuba, Acará, Barcarena, Bujaru, Concórdia do Pará, Moju, Tailândia e Tomé-Açu (CNBB, 2009).
} 
membros da CEB que ocorre o contato e o envolvimento com outras instituições, movimentos, sindicatos e associações do estado.

É nesta intricada relação entre fé e política que, com o objetivo de buscar a regularização de suas terras, as famílias da comunidade Campo Verde contribuíram para a fundação da ARQUINEC, em 2001. Sempre que convocados, os moradores participam das reuniões, mobilizações, eventos e cursos realizados pela associação.

Existem também aqueles moradores associados ao Sindicato de Trabalhadores e Trabalhadoras Rurais de Concórdia do Pará e também de Bujaru, já que existem delegados sindicais dos dois sindicatos na comunidade. Os delegados sindicais são os representantes dos sindicatos nas comunidades. Com essa representação em seu território a comunidade torna-se uma Delegacia Sindical. O delegado sindical é escolhido, por meio de votação, entre e pelos membros da comunidade, desde que sindicalizados e em dia com as mensalidades. $\mathrm{O}$ fato de a comunidade ter dois delegados sindicais se explica porque até 1988 ela pertencia ao município de Bujaru. Quando houve a criação do município de Concórdia do Pará, ela passou a fazer parte de Concórdia do Pará. Mesmo assim, o sindicato de Bujaru continuou com um representante em Campo Verde.

Algumas mulheres se reúnem no Grupo de Mulheres da comunidade Campo Verde. O Grupo de Mulheres é a célula de atuação do Movimento das Mulheres Transformadoras do Campo e da Cidade de Bujaru (MMTCCB) nas diversas comunidades do município de Bujaru e de Concórdia do Pará ${ }^{77}$. Com onze integrantes, o grupo se reúne aos sábados e, em 2008, discutia sobre a necessidade de retomada da casa das mães que estava emprestada a uma família que estava construindo sua casa; sobre a realização de uma roça para a produção e a comercialização da farinha com o objetivo de angariar fundos para pintar a casa das mães; sobre o encontro municipal de mulheres no Santo Antônio; sobre a mobilização dos maridos das participantes para ajudarem no preparo da roça e sobre a colaboração no bingo que o grupo de mulheres da comunidade Dona estava realizando.

De acordo com uma das fundadoras do grupo, o mesmo surgiu em 1985, a partir do apoio das comunidades Sant'Anna e Galho, com o objetivo de se realizar a ajuda mútua entre as mulheres. No início o grupo possuía uma máquina de costura para que as participantes pudessem costurar roupas para os seus filhos ou para vender, preparar roupas para o enxoval

\footnotetext{
77 O MMTCCB surgiu no final dos 1960 tendo como grande referência a trajetória de Margarida Silva. Margarida era do interior do município de Bujaru, mas migrou para a cidade onde participava do Clube de Mães, do Grupo de Evangelização e foi animadora e monitora de comunidade, muito ligada às CEBs. Sua atuação no meio urbano, com a fundação do movimento na cidade de Bujaru, estende-se para o meio rural, agrupando também as reivindicações das mulheres que nele viviam (COSTA, R., 2008).
} 
delas mesmas e vender para as mulheres da comunidade. Estas atividades no momento estão paradas, mas as mulheres estão se organizando para retomá-las. Foi deste grupo que foi eleita a coordenadora do MMTCCB no IX Congresso do movimento realizado na comunidade Santo Antônio, em novembro de 2008, cujo tema era "Mulher e Natureza" e o lema "Preserve e Cuide". Um dos temas abordados no evento foi a violência contra a mulher e a Lei Maria da Penha (Foto 12).

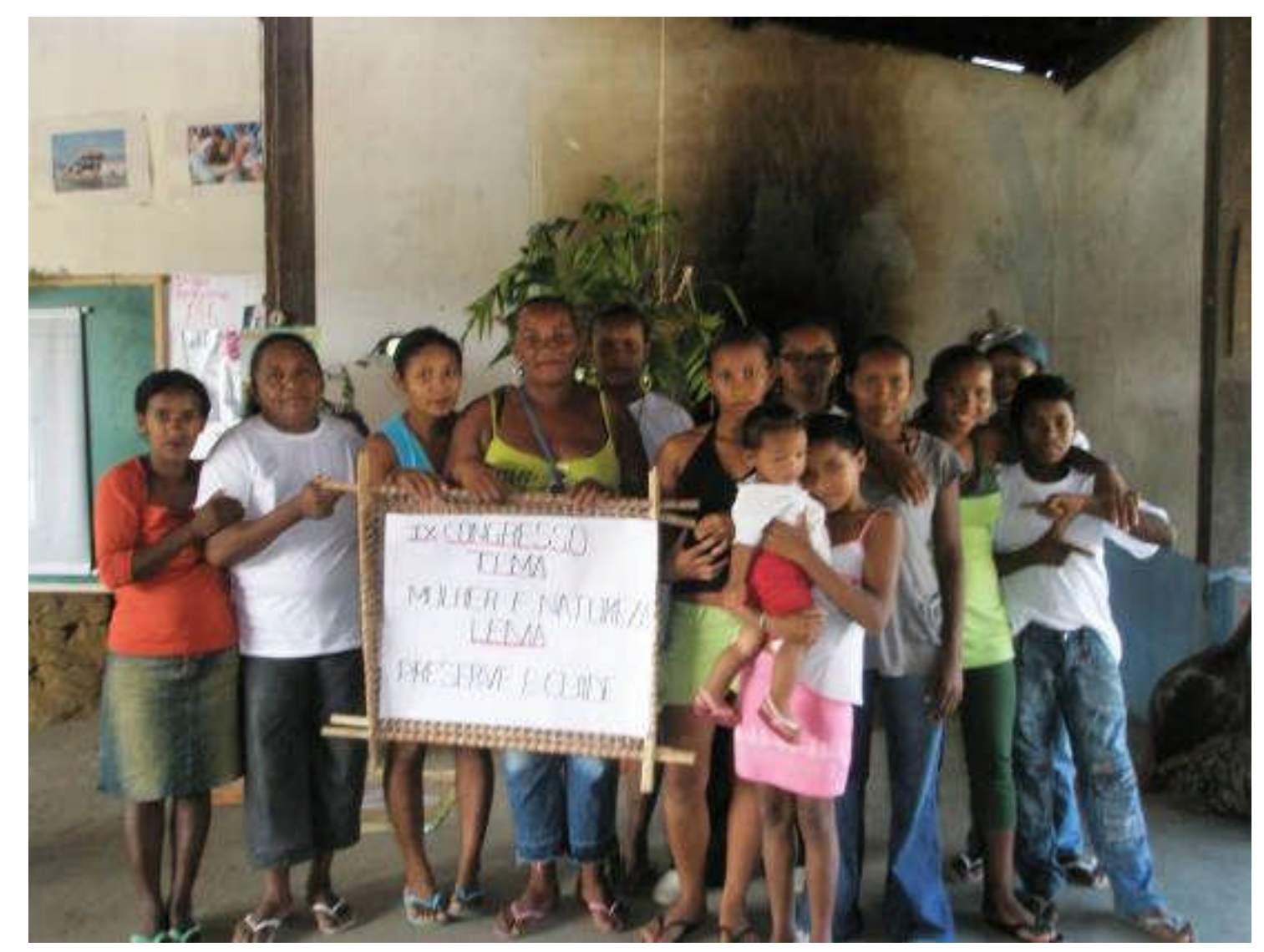

Foto 12: Participantes do grupo de mulheres de Campo Verde no IX Congresso do MMTCCB, em Santo Antônio, Concórdia do Pará (foto da autora em nov./2008).

A origem do grupo de mulheres está nos Clubes de Mães que existiam na década de 1980. As mulheres se reuniam aos sábados para costurar, fazer comida (doces e salgados), bordados, crochês, pinturas e tricô. Nestes momentos, compartilhavam suas experiências de donas de casa e mães. As atividades de venda dos produtos produzidos por elas serviam para atender as necessidades e funcionavam como ajuda mútua (COSTA, R., 2008).

A passagem de Clube das Mães para o MMTCCB ocorreu por meio da intervenção da Igreja Católica que, por meio de uma religiosa, mudou o rumo da atuação de muitas das mulheres dos Clubes, que passaram a ter uma visão mais reflexiva da realidade e a 
imprimirem um caráter mais político-social a estes Clubes, transformando os mesmos em Movimento das Mulheres. Apesar desta mudança, não há uma ruptura imediata com as atividades praticadas no Clube de Mães, que muitas vezes foram incorporadas como uma alternativa de renda e trabalho. Em outras comunidades, como em Santana, a denominação de Clube de Mães permanece, embora participem de muitas atividades do movimento (COSTA, R., 2008).

Além da participação no MMTCC, o grupo de Campo Verde também participa dos eventos que envolvem os debates sobre a mulher e a questão racial. Um exemplo disto foi a ida de representantes do grupo, no período de 19 a 22 de novembro de 2008, para o Encontro de Mulheres Negras Quilombolas, no município de Inhangapi, onde discutiram sobre a importância da organização e da valorização da mulher negra.

Em relação à infra-estrutura na comunidade, no que se refere, por exemplo, a água, não existe o serviço de abastecimento. Nestas condições, o acesso a um igarapé ou ao rio Bujaru é de fundamental importância. É destes cursos d'água que vem parte da água necessária para o abastecimento da posse familiar. Eles também são os locais do banho, de lavar a roupa e a louça, e também da diversão, principalmente para as crianças. Cada vez mais o igarapé enquanto local de pesca se reduz, pois os peixes estão diminuindo, em número e em tamanho. O igarapé também é o local de colocar a mandioca de molho para fazer a farinha.

Para os que moram mais distantes de um igarapé, ou quando o igarapé próximo não oferece mais condições de uso ou é muito pequeno, o poço é a alternativa. Em geral ele fica próximo à casa, facilitando assim o uso da água. Alguns moradores possuem bomba d'água ligada ao poço, o que facilita o encanamento da água para ser utilizada na propriedade e dentro de casa. Isto graças à energia elétrica que existe somente ao longo do "ramal do senhor Crescêncio", instalada em 2008, e no arraial, desde 2003, fato que limita o acesso a essa facilidade a apenas algumas famílias.

$\mathrm{O}$ atendimento médico que recebem os moradores ocorre nas comunidades Curuperé e Galho, vizinhas a Campo Verde. Ela é a referência para os moradores que estão na margem esquerda do rio Bujaru, enquanto que a comunidade Galho é a referência para os que residem na margem direita deste rio. Em caso de uma emergência médica, três famílias possuem celular que funcionam ligados a uma antena e que podem ser utilizados para chamar a ambulância da prefeitura, já que o serviço de telefonia pública não existe na comunidade. $O$ atendimento médico que recebem os moradores também pode ocorrer nos municípios de Concórdia do Pará, Bujaru ou Belém, dependendo da gravidade do estado de saúde e do tratamento necessário. 
Nas próprias comunidades, a possibilidade de tratamento de algum problema de saúde pode ocorrer por meio do uso de plantas medicinais. Neste caso, nada como um bom vizinho para ajudar com as plantas que não se tem em casa e com o conhecimento sobre chás, óleos e massagens. Dona Maria, esposa do senhor Agripino, é a referência quando se trata de remédios caseiros. Além de indicar e fazer os remédios, ela também realiza partos e benze.

O serviço de transporte é feito por meio de uma caminhonete e um caminhão. Em visita realizada em fevereiro de 2010, havia um microônibus que também realizava esse serviço. Os motoristas não são moradores da comunidade, mas das proximidades e fazem linha entre as várias comunidades - quando as condições da estrada vicinal permitem - e a cidade de Concórdia do Pará (Foto 13).

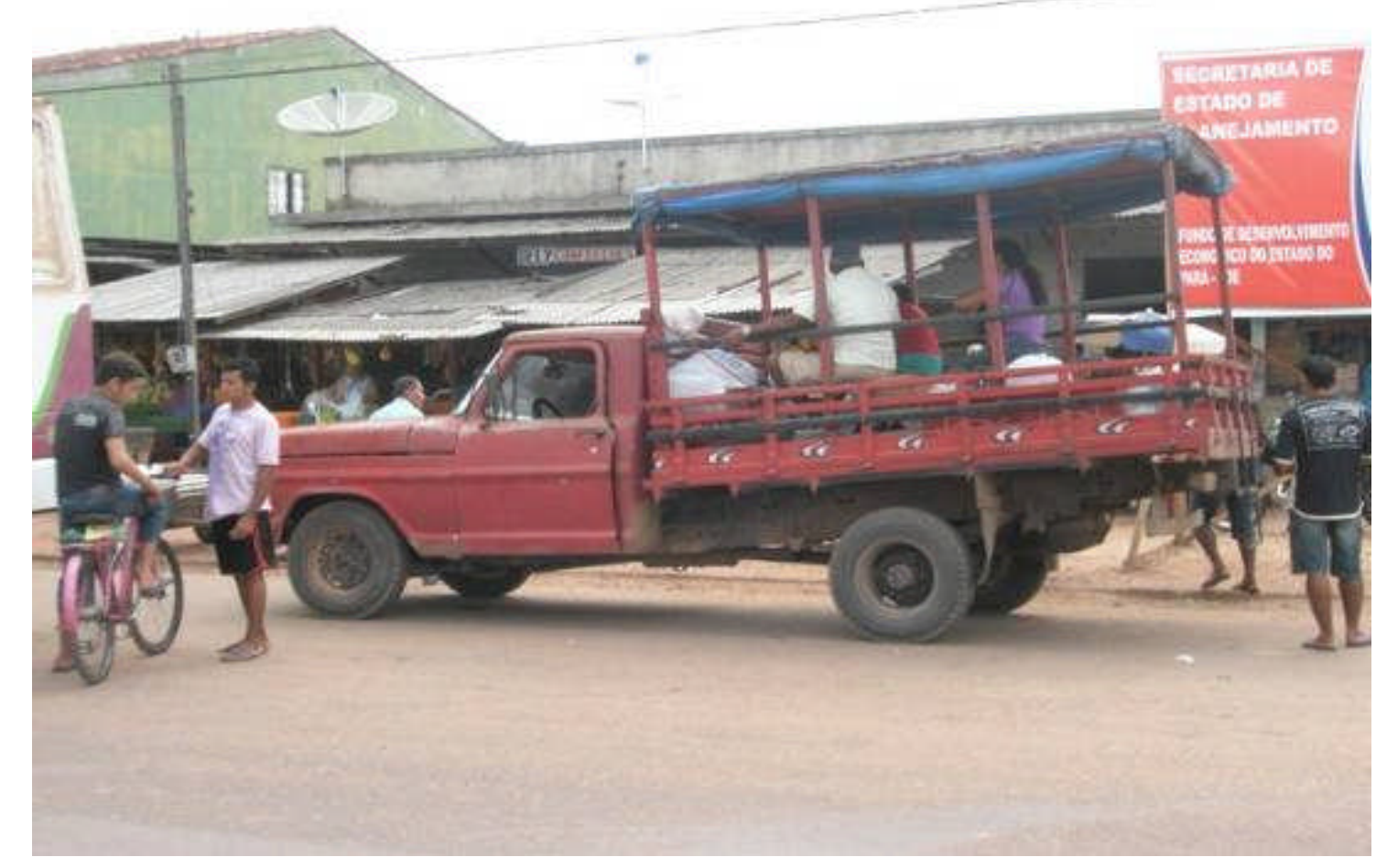

Foto 13: Caminhonete que transporta os moradores de Campo Verde e de algumas comunidades pela Transjutaí. Dentro do carro as pessoas esperam as que ainda estão fazendo compras na cidade de Concórdia do Pará para voltarem à suas comunidades (foto da autora em out./2008).

Estes veículos só entram na comunidade caso ocorra a formação de um grupo de pessoas que vá para a cidade de Concórdia do Pará. Este grupo comunica com antecedência o dia de ida à cidade a um dos motoristas que se responsabiliza por passar na comunidade na ida e na volta. Eles passam na comunidade entre $4 \mathrm{~h} 00$ e $5 \mathrm{~h} 00$ e chegam de volta às $13 \mathrm{~h} 00$, aproximadamente. Geralmente os moradores solicitam este serviço de transporte na época de pagamento (bolsa família, aposentadoria ou salários dos que são servidores públicos), e é 
quando aproveitam para realizarem o pagamento de suas contas e para fazer compras, principalmente de alimentos (carne, arroz, feijão, café, bolacha, açúcar, sal, óleo, sabão, etc.), mas também de remédios, roupas e calçados. As consultas médicas também são motivos de viagem. Além da caminhonete, do caminhão e do microônibus, existe o ônibus escolar, que pode levar os moradores até a estrada vicinal Transjutaí, na comunidade Galho.

Quando os moradores precisar ir a Belém, é necessário viajar para a cidade de Concórdia do Pará para, de lá, tomarem os ônibus da empresa Boa Esperança que passam na cidade com destino à capital. $\mathrm{O}$ tempo gasto pelos moradores da comunidade até Belém é de aproximadamente cinco horas e meia, o que depende das condições de tráfego das vicinais que ligam a comunidade à cidade de Concórdia do Pará, podendo ainda aumentar.

As famílias podem também se utilizar do transporte fluvial. Os barcos passam pela comunidade, no rio Bujaru. Fazem linha todas as quintas somente para Bujaru e Belém, passando por Campo Verde entre as $12 \mathrm{~h} 00$ e 14h00, chegando a Belém na sexta entre 3h00 e $4 \mathrm{~h} 00$ e voltando no mesmo dia entre $14 \mathrm{~h} 00$ e $16 \mathrm{~h} 00$ e chegando à comunidade na madrugada do sábado (Foto 14). As famílias podem demorar cerca de 40 horas neste trajeto, se quiserem vender a farinha em Belém. Por este motivo é que preferem vender a farinha para os donos de barco ou "marreteiros", como denominam os compradores da farinha que vão em suas casas.

Esta venda ocorre principalmente quando elas possuem menos de 10 pacotes de farinha, pois os custos são grandes na viagem para Belém. 


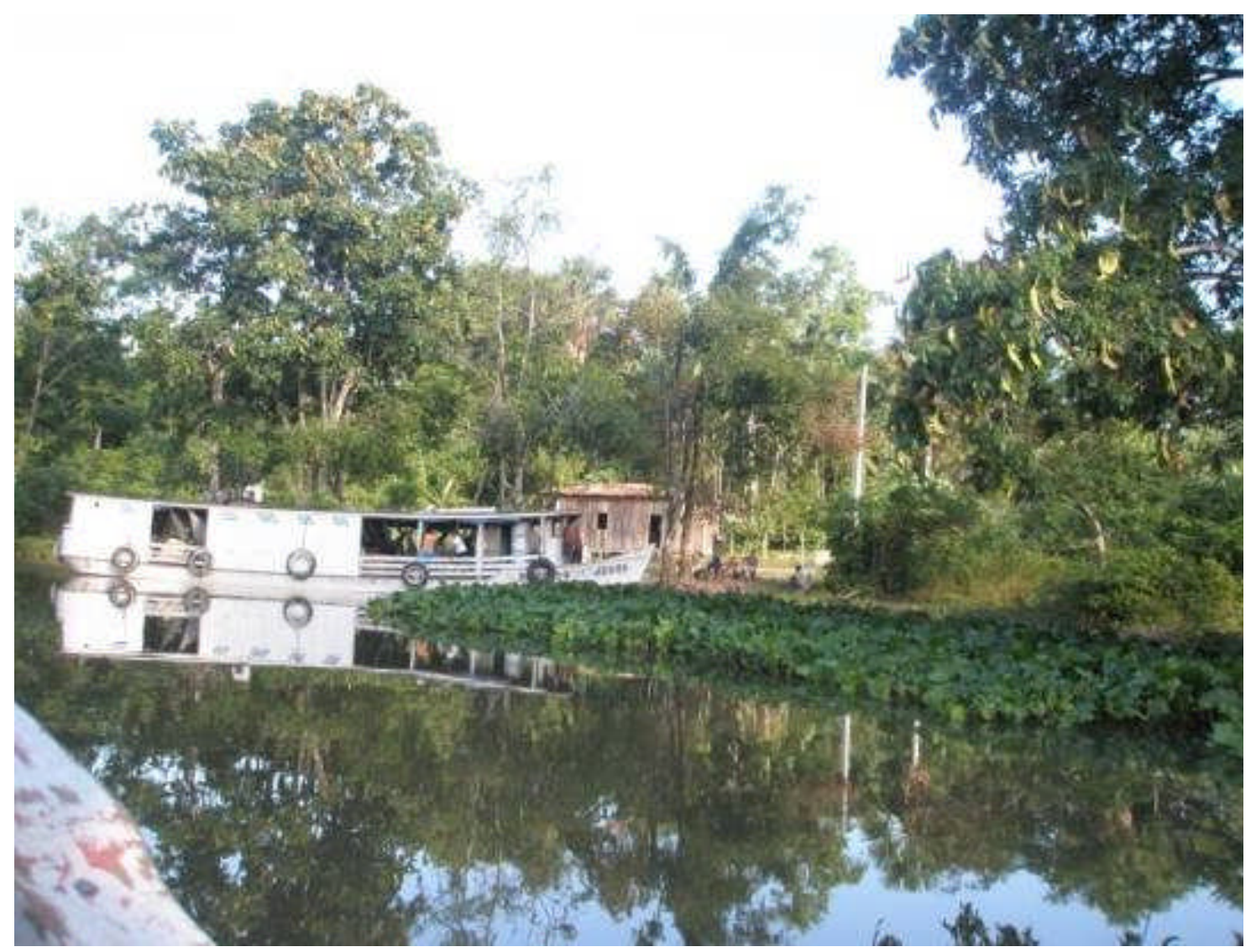

Foto 14: Barco no rio Bujaru que transporta pessoas e produtos de diversas comunidades de Bujaru e de Concórdia do Pará para Belém (foto da autora em out./2008).

Sobre a educação, à margem direita do rio Bujaru existe somente uma escola onde se ensina da alfabetização até a quarta série do ensino fundamental, sendo a professora da própria comunidade. A construção é de alvenaria, com uma sala de aula, cozinha e secretaria. A escola possui água encanada.

Os alunos, ao passarem para a quinta série, viajam cerca de $8 \mathrm{~km}$ para chegar à comunidade Galho, onde funciona uma escola com o Sistema Regular (de $1^{\circ}$ a $4^{\circ}$ série) e o Modular de Ensino (de $5^{\circ}$ série do ensino fundamental ao $3^{\circ}$ ano do ensino médio). Esta escola atende várias comunidades próximas. No Sistema Modular os alunos têm duas disciplinas por bimestre, até o final do ano. Os alunos da comunidade Campo Verde são transportados pelo ônibus escolar municipal, que também circula em outras comunidades. $\mathrm{Na}$ comunidade Galho também funciona a Educação de Jovens e Adultos (EJA), à noite, em um espaço cedido na casa de um dos moradores. A professora é a mesma que trabalha na comunidade Dona, mas é moradora de Campo Verde.

Os alunos que moram à esquerda do rio Bujaru, as crianças principalmente, estudam em uma escola às margens do rio Bujaru, na comunidade João Igarapé. Para chegarem à 
escola precisam atravessar cerca de um quilômetro de igapó, por cima de estivas, para chegarem às margens do rio e pegar uma canoa. Nesta canoa atravessam o rio e viajam alguns minutos até o local onde fica a escola. Esta canoa já virou uma vez, mas felizmente as crianças maiores conseguiram salvar as menores. Por estes motivos, os moradores deste lado da comunidade estavam pleiteando junto à prefeitura a abertura de uma turma multisseriada. Inclusive já conseguiram uma casa que teria o espaço da sala cedido para a escola. No entanto, encontram muita resistência por parte da atual professora das crianças, que perderia os alunos e conseqüentemente poderia perder o aluguel da sua canoa que transporta os alunos e é pago pela prefeitura, segundo uma das mães das crianças.

Os jovens que estudam da quinta série ao ensino médio precisam seguir andando, de bicicleta ou a cavalo para a comunidade Curuperé, que dista três quilômetros de Campo Verde, para ali poderem pegar o ônibus escolar que os levará até a comunidade Cravo, onde fica a escola em que estudam à noite. Com as dificuldades encontradas, principalmente no que se refere ao transporte, ao longo do ano de 2008, todos os dez alunos que estavam estudando desistiram.

Na comunidade o lazer é marcado, na maioria das vezes, pelo jogo de futebol que geralmente ocorre no sábado à tarde. Campo Verde tem dois campos de futebol, estando a sede do time em um deles. Possui também três times de futebol, sendo um feminino e dois masculinos. Os jogos podem ocorrer na própria comunidade, entre os moradores, ou com um time visitante, de outra comunidade. Também pode ocorrer de os times da comunidade se deslocarem para outras comunidades para jogar. Geralmente isso se realiza quando organizam o torneio, sendo o prêmio geralmente uma ou mais grades de cerveja.

Além do futebol, existem as festas de brega, um ritmo musical, em grande parte derivado do bolero, que surge em fins da década de 1970 (COSTA, A., 2008). Estas festas são realizadas com pequenas aparelhagens de som na própria comunidade ou nas comunidades vizinhas, como Galho, Jutaí Grande e Cravo, para onde os que gostam das festas se dirigem. Nestas três comunidades as aparelhagens vêm de Belém, como Pop Som, Tupinambá e Príncipe Negro. Segundo Costa, A. (2008), as aparelhagens são

[...] empresas de sonorização voltadas especialmente para a realização de festas de brega. Normalmente de propriedade familiar e administradas por famílias [...]. As aparelhagens são, em geral, classificadas como de pequeno, médio ou grande porte em razão de sua potência sonora, embora contem, também, para essa classificação, o valor dos contratos para festas, sua popularidade e suas ligações com outros empresários do circuito bregueiro: donos de casas de festa e festeiros (contratantes particulares de festas). No sentido estrito, a aparelhagem é o equipamento sonoro composto de uma unidade de controle e seu operador (o D.J.), que possibilitam o uso de 
diversos recursos e alta qualidade na emissão musical. Suas caixas de som, que comportam diversos alto-falantes e tweeters, agrupados no formato de colunas de 3 a 5 metros de altura, aproximadamente, fazem parte do conjunto. A disposição do equipamento sonoro das aparelhagens nas festas de brega é muito parecida com as das radiolas das festas de reggae do Maranhão e com as das equipes dos bailes funk do Rio de Janeiro" (COSTA, A., 2008, p. 18, grifo do autor).

As festas de brega com as grandes aparelhagens ocorrem com menos freqüência pelo fato de serem aparelhagens que cobram muito caro para tocar e exigem uma infra-estrutura mínima por parte da comunidade que as recebe, para a cobrança de ingressos, além de espaço físico, pois o número de pessoas que participa destas festas é muito grande. Trata-se do chamado "fenômeno das aparelhagens" que já foi inclusive objeto de estudo na pós-graduação em antropologia da $\mathrm{USP}^{78}$. Elas ocorrem geralmente aos sábados, por ocasião das férias escolares de julho, ou na festa de fim de ano. Os organizadores escolhem um período em que geralmente os amigos e parentes que moram em Belém, Ananindeua e Marituba vão passar as férias nas comunidades, aumentando assim o público da festa.

Os jovens gostam das festas de brega animadas pela música tecnobrega que, de acordo com Costa, A. (2008), é uma fusão da música brega padrão com elementos eletrônicos do teclado e da mesa de som. Já o tipo de festa que agrada principalmente os adultos é a festa chamada baile da saudade. Nelas, de acordo com Costa, A. (2008), as aparelhagens que tocam são especializadas nestes tipos de eventos. Elas possuem um repertório musical composto de boleros, sambas-canção, merengues e temas de seresta. Destaca-se, neste tipo de festa, uma

[...] constante evocação de uma memória e de um sentimento de retorno ao passado da experiência de vida, assentados no conteúdo das músicas tocadas e na identidade da aparelhagem com as festas "do passado", das gafieiras, das sedes profissionais e de sindicatos, sonorizadas pelas antigas pickarpes ou sonoros, típicos das décadas de 1950 e 1960 (COSTA, A., 2008, p. 1, grifos do autor).

Para Costa,

[...] os bailes da saudade fazem parte do circuito bregueiro, uma vez que suas festas ocorrem nas mesmas casas, com os mesmos festeiros (contratadores particulares de festas) e aparelhagens ligadas ao circuito de eventos de brega dos demais tipos de festa. Sua marca específica, contudo, se funda no tipo de música apresentada e no tipo de público freqüentador (COSTA, A., 2008, p. 18).

\footnotetext{
${ }^{78}$ COSTA, Antônio Maurício Dias da. Festa da cidade: o circuito bregueiro de Belém do Pará. São Paulo: FFLCH/USP, 2004. 263p. (Tese de doutorado em Antropologia)
} 
Mas não só de futebol e festas de brega vivem as famílias. São Tomé é o santo padroeiro de Campo Verde. Sua festividade é realizada no mês de dezembro, quando, durante duas semanas antes do dia da festa de São Tomé, são realizadas as novenas de casa em casa pelos três grupos de evangelização e no último dia é realizada uma celebração com a presença do padre (Foto 15). Nas novenas são realizados cantos, orações, leitura bíblica e, no fim, bingos para arrecadar fundos para a igreja.

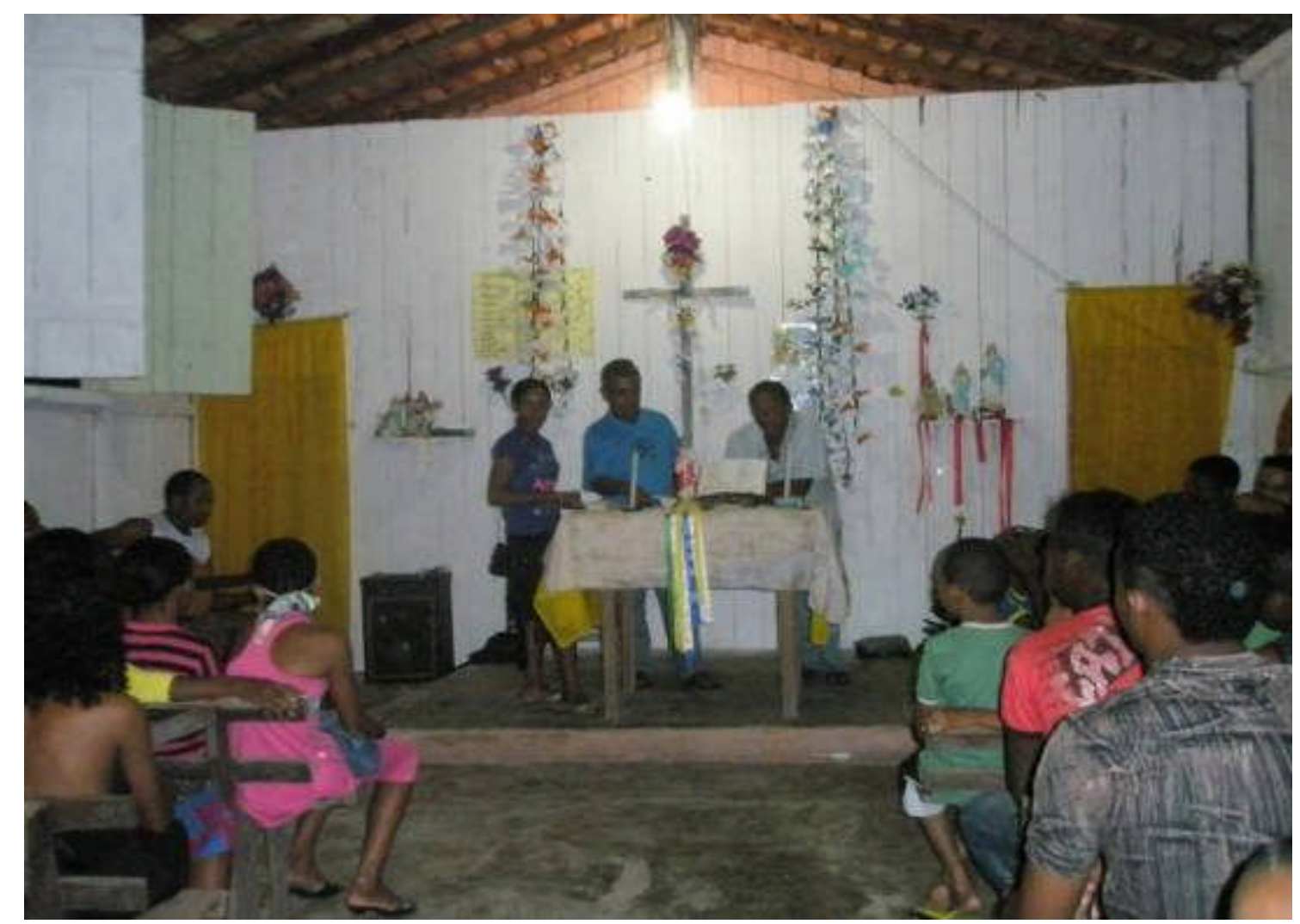

Foto 15: Culto em homenagem a São Tomé, padroeiro da comunidade, realizado nas véspera da Missa com o padre (foto da autora em dez./2008).

Para os trabalhos do dia da festa, que pode ser o segundo ou o terceiro sábado do mês (e não necessariamente no dia de São Tomé, 3 de dezembro), são organizadas várias equipes: a que vai organizar o torneio de futebol, a que vai enfeitar a igreja, a de liturgia, a da comida, etc.... Neste dia da festa, existem várias atividades que os moradores chamam de "brincadeiras": o torneio de futebol, o bingo e o lance. Durante a tarde é realizado o torneio de futebol, disputado entre os times da comunidade e os de diversas comunidades das redondezas. O prêmio normalmente é uma ou duas grades de cerveja. Pela noite, se inicia a festa propriamente dita, que não é dançante (orientação da diocese) e só ocorre depois da missa com o padre de Bujaru. Na festa, as pessoas jogam o bingo e fazem o lance. O lance é 
quando uma pessoa sai oferecendo um brinde e as demais vão dando valor para o mesmo, sendo que aquele que dá o maior lance fica com o brinde. É como se fosse uma espécie de leilão. Os prêmios do bingo e os brindes do lance são doados por pessoas da comunidade ou alguém de fora, podendo ser, para o bingo, açúcar, sal, refrigerantes, frutas, bebidas, ventilador, etc., e para o lance, bolos, frango assado, carne cozida, frutas, etc. (Foto 16). Todo o valor obtido nestas "brincadeiras" é destinado à igreja, principalmente nos últimos três anos em que a igreja estava em obras. Foi, aliás, com esses recursos que a comunidade construiu a nova igreja, em alvenaria, concluída em 2009 e que é um orgulho para a comunidade (Foto 17).

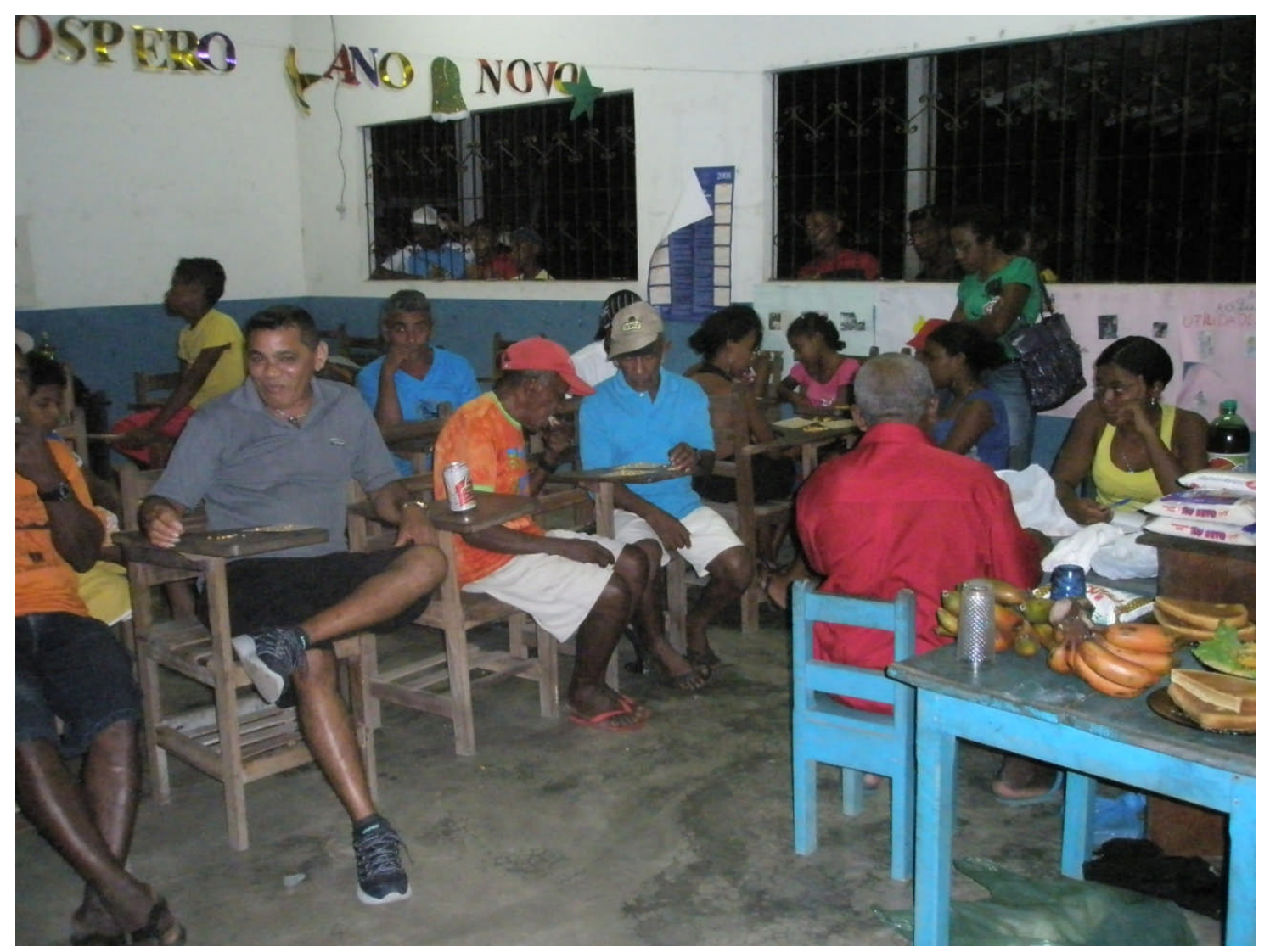

Foto 16: Festa na sala de aula da escola, no momento do bingo. À direita estão alguns dos brindes doados por famílias da comunidade (foto da autora em dez./2008). 


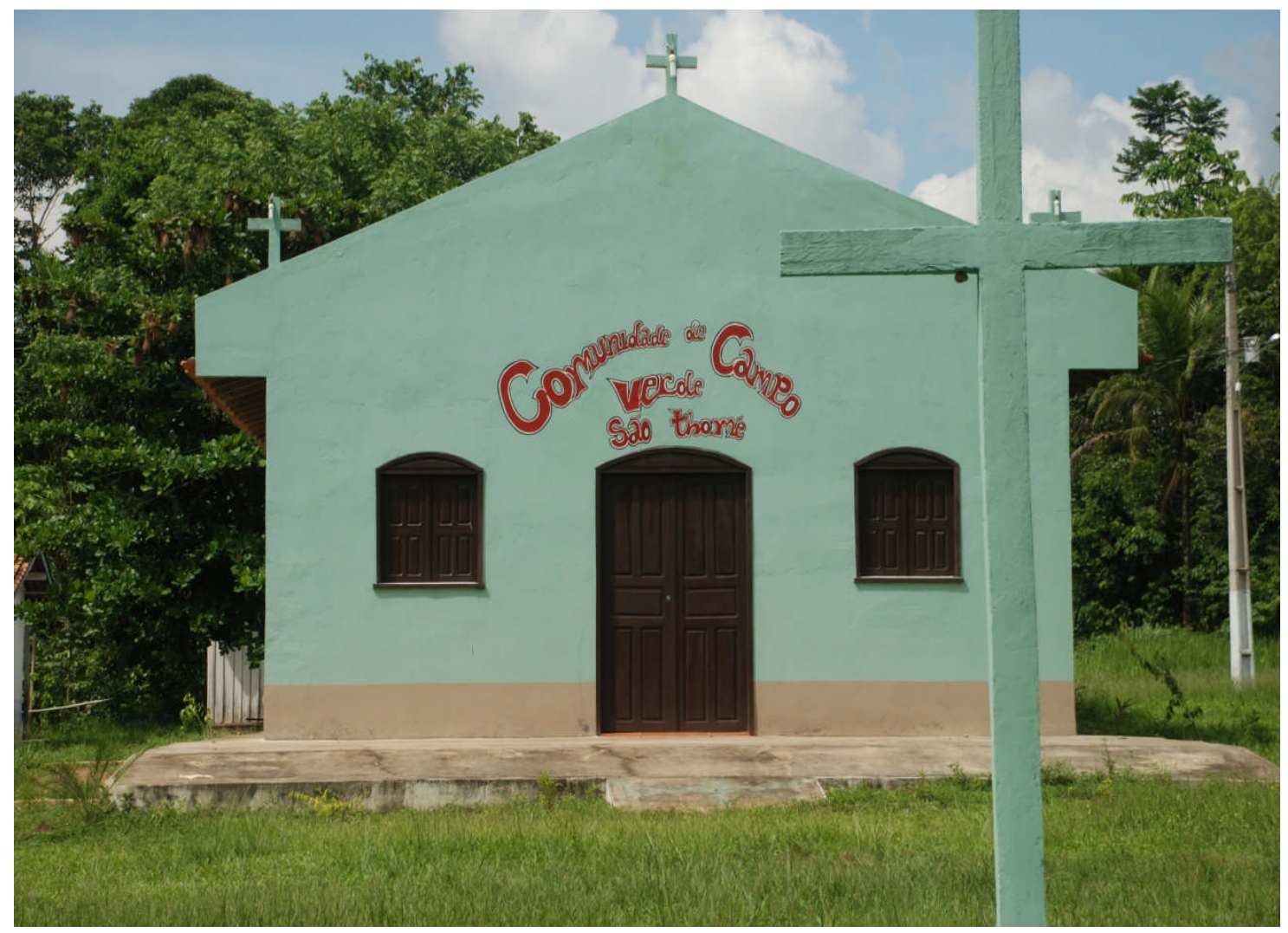

Foto 17: A nova igreja de Campo Verde (Valéria de Marcos em jan./2010).

Apesar de toda esta preparação para a festa de São Tomé, segundo alguns moradores, a maior festa é a de Nossa Senhora do Livramento, no mês de maio (Mês de Maria). As novenas nas casas dos moradores duram um mês. As famílias que desejam ter uma novena em suas casas avisam a coordenação da festa, com antecedência, o melhor dia para que ela seja feita. Na novena são realizadas orações, cânticos, leitura bíblica e sempre relacionam o que lêem com o cotidiano vivenciado na família e na comunidade. No dia da festa o público é grande e também ocorrem "as brincadeiras” que acontecem na festa de são Tomé.

Estas duas festas se originam da devoção do avô e do pai do senhor Miguel, quando chegaram à comunidade na década de 50. O avô era devoto de São Tomé e já realizava a "festa do santo" na comunidade em que a família de seu Miguel morava antes de ir para o Campo Verde. O pai era devoto de Nossa Senhora do Livramento, e quando morreu disse que a padroeira de Campo Verde deveria ser Nossa Senhora. Com a criação da comunidade religiosa oficialmente pela igreja de Bujaru, ficou São Tomé como padroeiro, mas a festa maior, melhor e mais bonita é a de Nossa Senhora do Livramento. 


\subsubsection{Jutaí-Mirim}

Localizada à margem direita do rio Bujaru e à margem de seu afluente denominado Jutaí-Mirim, esta comunidade dista $35 \mathrm{~km}$ da sede do município de Concórdia do Pará (Mapa 1). O seu acesso pode ser fluvial, por meio do rio Bujaru, ou rodoviário, pela PA 140 até a altura do km 72, na cidade de Concórdia do Pará, onde, por uma estrada vicinal denominada Transjutaí, percorre-se $35 \mathrm{~km}$ para chegar à estrada vicinal que corta a comunidade. $\mathrm{O}$ acesso também pode ser pela PA 140 até o $\mathrm{km} \mathrm{17,} \mathrm{de} \mathrm{onde} \mathrm{se} \mathrm{entra} \mathrm{para} \mathrm{a} \mathrm{estrada} \mathrm{vicinal}$ Providência, no fim da qual se atravessa uma ponte sobre o rio Bujaru, acessando assim a estrada vicinal Transjutai até chegar à estrada vicinal da comunidade.

Jutaí-Mirim faz limite com o rio Bujaru e com as comunidades Jutaí Grande e Ipanema. Esta comunidade possui aproximadamente 80 famílias distribuidas em uma área de 2.265,7652 ha. As posses destas famílias ficam dispostas ao longo da estrada vicinal, bem como ao longo dos diversos caminhos que adentram a mata, e ainda às margens do rio Bujaru.

As terras da Comunidade de Jutaí-Mirim estão inseridas na Gleba Bujaru, a qual foi objeto de uma ação discriminatória na década de 1980, tendo a área do Jutaí-Mirim sido arrecadada e matriculada em nome da União.

Na comunidade há um núcleo, chamado arraial, localizado nas terras de uma das famílias, onde fica a igreja de alvenaria, erguida em homenagem a Nossa Senhora de Fátima, padroeira da comunidade; a barraca da santa, de madeira; a escola, também de madeira, e duas residências. Nas proximidades ficam a sede do time de futebol e o campo de futebol (Foto 18). 


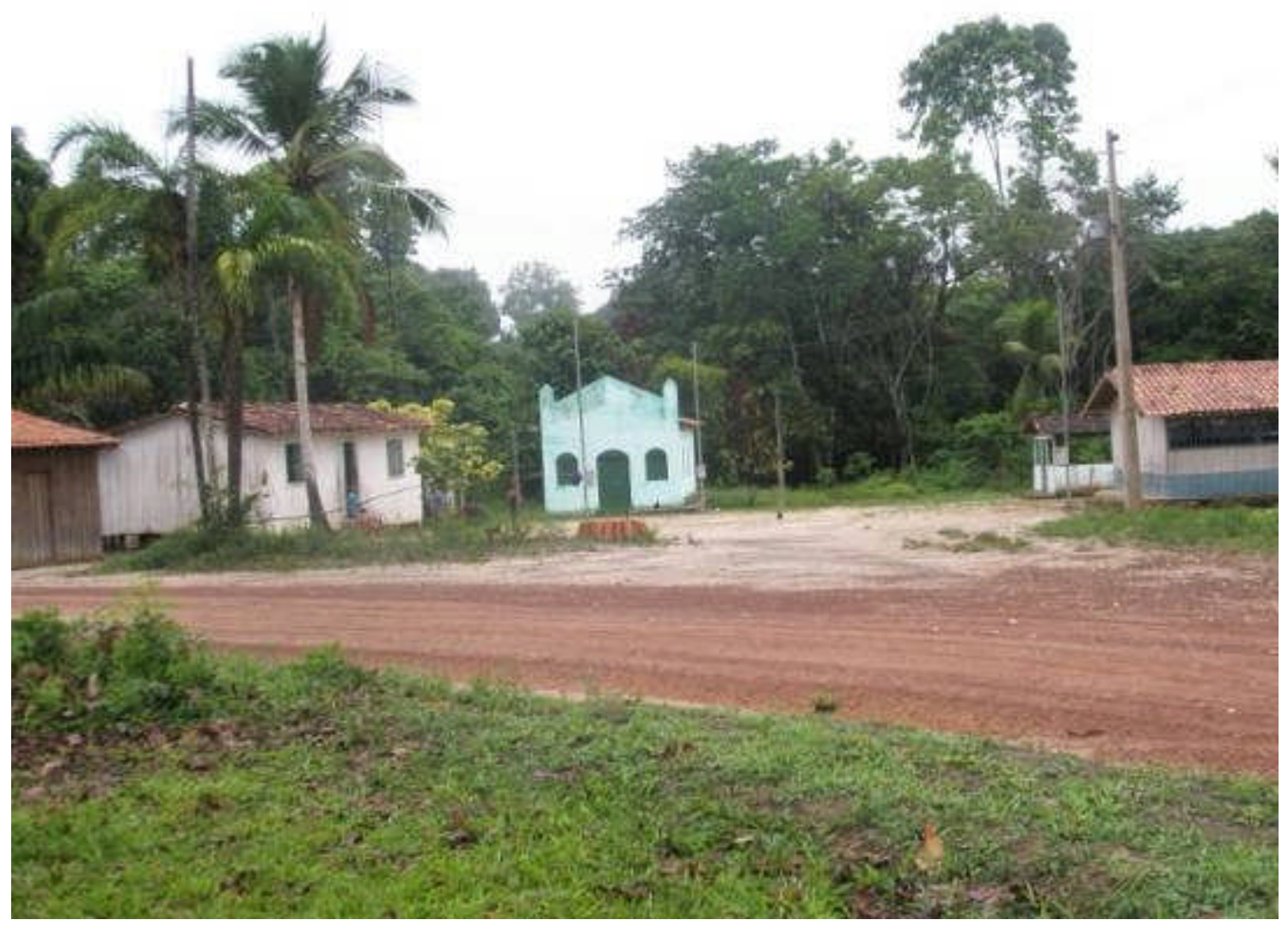

Foto 18: Arraial do Jutaí-Mirim. Da esquerda para a direita, temos as casas da família do senhor Manoel, a igreja de N. S. de Fátima, a barraca da santa e a escola. No primeiro plano observa-se no chão um capim baixo: é parte do campo de futebol. Temos também a estrada vicinal que, pela esquerda segue para a comunidade Ipanema, e pela direita para a estrada vicinal Transjutaí (foto da autora em jan./2009).

Em Jutaí-Mirim mora o senhor Olímpio, de 76 anos, em terras herdadas de sua mãe. Segundo ele, as terras que margeiam o rio Bujaru, da foz do igarapé Jutaí-Mirim até a localidade chamada Memória, pertenciam a duas famílias: a Mendonça e a Oliveira Lima. As terras destas duas famílias abrangiam quase toda a área territorial da comunidade tal qual é hoje e que foi sendo formada a partir da venda de parte das terras destas propriedades para outras famílias. Destas se destaca a família Perdigão, que comprou uma grande extensão de terras dos Mendonça e mais tarde vendeu uma parte. Apesar deste repassar de terras, os descendentes das famílias Mendonça, Oliveira Lima e Perdigão continuam na comunidade em posses divididas entre os herdeiros.

Dentre as atividades produtivas desenvolvidas pelas famílias na década de 1940 (data que o senhor Olímpio recorda bem), destacava-se o arroz, dentre outros produtos como banana, milho e mandioca. Estes produtos eram vendidos para um grande comerciante, Antônio Machado, que morava na foz do igarapé castanheiro, afluente do rio Bujaru. Além 
desta produção, havia a extração de madeira das espécies acapu, angelim, massaramduba, pau d'árco, piquiazeiro para a construção das casas e canoas.

O senhor Olímpio transportava sua produção em uma canoa a vela, pertencente a Paulo Tavares. Depois de casado, passou a levar seu arroz para um moinho que existia em Inhamgapi, município que fica do outro lado rio Guamá, em frente à foz do rio Bujaru. Segundo senhor Antônio, presidente da associação do assentamento, tudo era transportado pelo igarapé Jutaí-Mirim, afluente do igarapé Jutaí, por onde prosseguiam viagem até alcançarem o rio Bujaru. Só no Jutaí-Mirim, durante o verão, época de seca e rios menos volumosos, a viagem podia demorar até o dia todo, mas no inverno, época de chuva e cheias dos rios, a viagem durava cerca de duas horas.

Nas visitas realizadas à comunidade desde 2008, as famílias estavam organizadas em torno da "comissão do assentamento". Embora a comunidade se encontre em área identificada como pertencente aos remanescentes das comunidades dos quilombos, ela optou por buscar a regularização de suas terras através do assentamento. A “comissão do assentamento" foi uma comissão provisória feita para iniciar a implantação do assentamento enquanto não se legalizava a Associação dos Trabalhadores do Assentamento Jutaí e Ipanema (ATAJI), necessária para a fase de desenvolvimento do assentamento ${ }^{79}$.

Uma forma de organização mais antiga na comunidade é a que existe em torno das atividades da Igreja Católica. Também aqui ela é formada por uma diretoria, grupos de evangelização e catequese. A diretoria é a responsável pela realização dos cultos todos os domingos pela manhã e pela coordenação de outras atividades religiosas. Assim como acontece com Campo Verde, a igreja local, de Nossa Senhora de Fátima, está vinculada à igreja do município de Bujaru e, portanto, à Diocese de Abaetetuba.

Em relação à infra-estrutura, para o abastecimento de água, o INCRA instalou um sistema que atende somente as poucas famílias que residem na pequena agrovila por ele construída. Sendo assim, os igarapés que passam pelas posses dos moradores, como o igarapé Jutaí-Mirim e o rio Bujaru, servem para o abastecimento da posse familiar, para o banho, para a preparação de alguns tipos de comida, principalmente quando é uma caça, para lavar a roupa e a louça e, tal como acontece em Campo Verde, para a diversão, principalmente das crianças. Também aqui os igarapés são usados para deixar a mandioca de molho, etapa necessária para o preparo da farinha d'água. A outra alternativa para o abastecimento é o poço, sendo que alguns moradores possuem bomba d'água ligada a ele, pois a comunidade conta com a

\footnotetext{
${ }^{79}$ Trataremos mais sobre esta associação quando falarmos sobre o pleito de titulação da comunidade.
} 
energia instalada pelo INCRA nas casas da vila e nas que ficam às margens da estrada vicinal que corta a comunidade.

Na área da saúde, a comunidade Galho é a referência para o atendimento médico dos moradores. Lá existe um posto de saúde, construído pela prefeitura de Concórdia do Pará, onde há atendimento clínico e odontológico. Quando precisam de um atendimento mais especializado, os moradores se dirigem para os municípios de Concórdia do Pará, Bujaru ou Belém. $\mathrm{O}$ uso de plantas medicinais também é uma alternativa de tratamento, e a senhora Esmeralda é a referência para o uso das plantas e outros recursos da natureza.

Em relação ao comércio, os comerciantes, denominados de marreteiros, são os que se destacam na compra da farinha produzida pelos moradores da comunidade, e na revenda para os donos de barcos que navegam no rio Bujaru, indo para diversas feiras em Belém. Quando precisam fazer compras, os moradores se dirigem para as cidades de Bujaru e Concórdia do Pará. Os que recebem salário, aposentadoria e bolsa família vão todo início de mês receber o auxílio, ocasião em que acabam deixando por lá também uma parte do que recebem, pois aproveitam a ida à cidade para comprar os mantimentos para o mês, remédios, roupas e calçados, para consultas médicas e comprar o que mais precisar na propriedade.

Em relação ao sistema de transporte, a comunidade Jutaí-Mirim, de todas as comunidades em estudo, é a que possui maiores dificuldades em relação a este serviço. Os moradores possuem quatro alternativas: ir a pé ou de bicicleta para a estrada vicinal Transjutaí, que dista cerca de $7 \mathrm{~km}$ da comunidade, onde passa um ônibus que vai para Concórdia do Pará (às 5:h00) e outro que vai para Bujaru (às 4:30h); um caminhão que entra uma vez por mês, no início do mês, para transportar os idosos para receberem a aposentadoria na cidade de Concórdia do Pará; o ônibus escolar, destinado apenas aos alunos, e que só vai até a comunidade mais próxima, Jutaí Grande, onde fica a escola de ensino fundamental e médio à qual se dirigem as crianças de Jutaí-Mirim após terminarem a quarta série. Em janeiro de 2010 havia um ônibus que, caso houvesse passageiro, entrava na comunidade às segundas e quartas-feiras.

Para viajarem para Belém, as famílias precisam ir até a cidade de Bujaru para pegarem os ônibus da empresa Boa Esperança que vêm de Concórdia do Pará. O tempo que eles gastam da comunidade até Belém é de aproximadamente cinco horas e meia. Todo este tempo gasto pelos moradores depende, em grande medida, das condições de tráfego nas vicinais que ligam a comunidade à cidade de Bujaru.

As famílias podem se utilizar também do transporte fluvial, que não vai para a cidade de Concórdia do Pará, pois esta fica a montante do rio Bujaru, onde este rio é menos largo e 
com pouca profundidade. Os barcos fazem linha todas as quintas-feiras somente para Bujaru e Belém, passando por Jutaí-Mirim entre as $16 \mathrm{~h} 00$ e 17h00, chegando a Belém na sexta entre 3:00 e 4:00. Os barcos retornam no mesmo dia, saindo de Belém entre 14:00 e 16:00 e chegando na comunidade na madrugada de sábado.

Em relação à educação, em Jutaí-Mirim também só existe uma escola com o ensino da alfabetização até a quarta série do ensino fundamental. Ao passarem para a quinta série, os alunos viajam cerca de $11 \mathrm{~km}$ para chegar à comunidade Jutaí Grande, onde se localiza a escola em que funciona o Sistema Regular e o Modular de Ensino. Os alunos que estudam no Jutaí Grande são transportados pelo ônibus escolar, que também circula em outras comunidades.

Para o lazer, o jogo de futebol é o que anima principalmente os jovens, que geralmente se reúnem aos sábados à tarde para jogar. Jutaí-Mirim tem dois times e dois campos de futebol, sendo que cada time tem sua sede. Assim como em Campo Verde, os jogos ocorrem na comunidade, entre os moradores ou com um time de outra comunidade vizinha, ou em outra comunidade. Geralmente isto ocorre quando tem torneio entre as comunidades.

Desde 2009 as festas de brega, ou "festas dançantes", como denominam, também passam a fazem parte do lazer dentro da comunidade, pois o clube de um dos times de futebol foi cercado, facilitando a realização de festas. Para as festas com as grandes aparelhagens, a comunidade Jutaí Grande é a referência para todos.

Além destas festas de aparelhagem também existe a festividade religiosa. Em JutaíMirim a padroeira é Nossa Senhora de Fátima e sua festividade sempre é realizada no mês de agosto. Na verdade deveria ser em maio, mas as famílias preferem em agosto porque em maio existem muitas outras festividades nas comunidades vizinhas, o que provoca a diminuição da participação de famílias desta outras comunidades na festividade em Jutaí-Mirim.

\subsubsection{Nova Esperança}

A comunidade Nova Esperança localiza-se ao longo da PA 140, entre os quilômetros 39 e o 42, sentido Concórdia do Pará, distando $31 \mathrm{~km}$ desta cidade. Sua via de acesso é a PA 140. Limita-se com as comunidades Curuperezinho, Nova Timboteua, Perpétuo Socorro e Arapiranga, possuindo cerca de 42 famílias (Mapa 1). As terras destas famílias estão localizadas na gleba Bujaru, lado esquerdo da rodovia, e na gleba Araxiteua, lado direito, 
sentido Concórdia do Pará. As moradias estão em grande parte situadas às margens da rodovia, e as demais em três estradas vicinais. Possui um núcleo, também chamado arraial, no km 40, onde está a igreja que está sendo construída em alvenaria; a igreja em madeira; a quadra de areia bem em frente à igreja; um posto médico recém-construído, e três casas da família antiga dona das terras onde fica o arraial e que foram doadas para a construção da igreja (Foto 19).

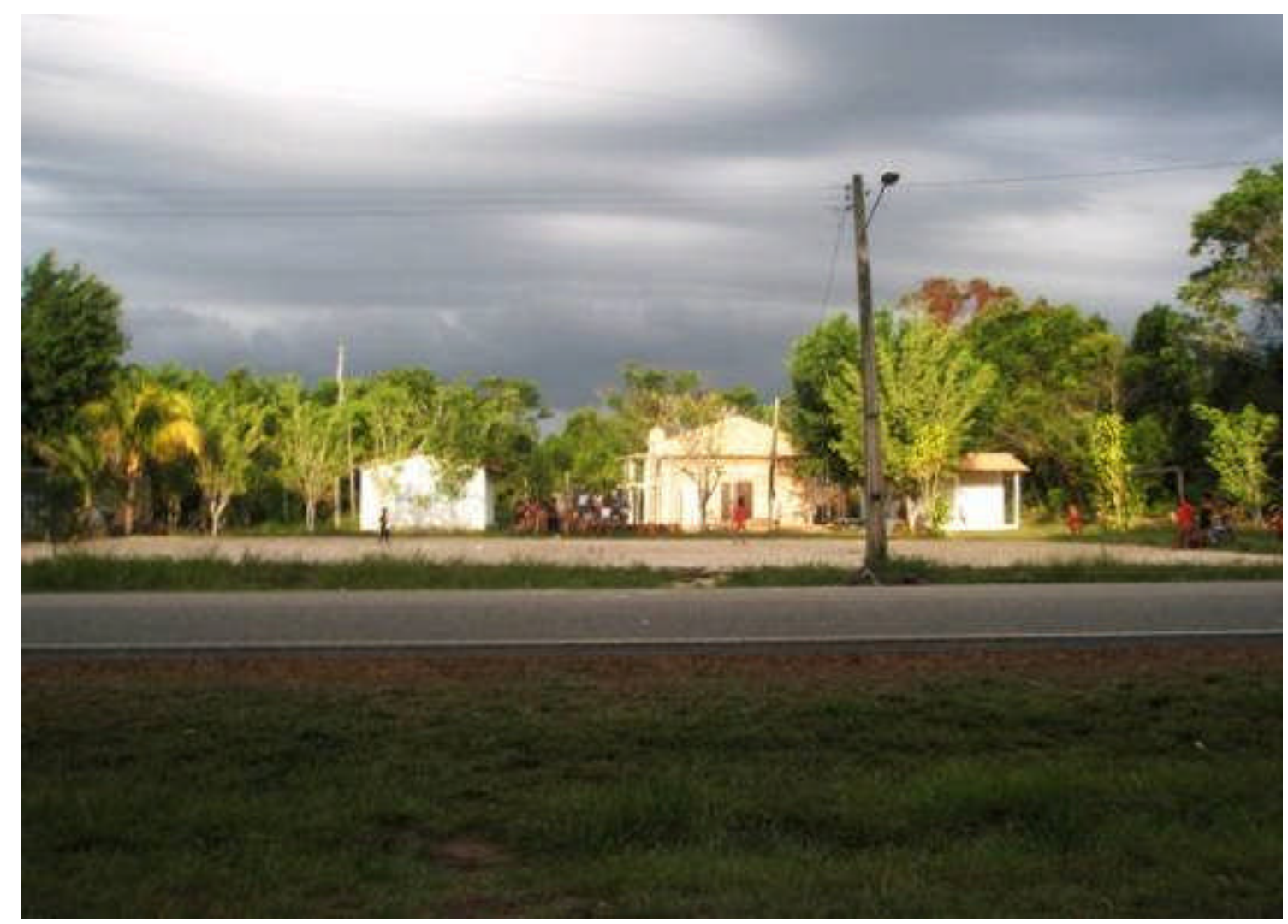

Foto 19: Arraial de Nova Esperança. Temos a rodovia PA 140, em seguida a quadra de areia, mais ao fundo, da esquerda para a direita, a igreja em madeira, a que está em construção e o posto médico. Este era o momento em que as jovens estavam aguardando chegar mais gente para iniciarem o jogo de futebol do sábado à tarde (foto da autora em out./2009).

A conformação de seu território está intimamente relacionada à construção de rodovias na Amazônia, que está inserida em um projeto do governo federal de ocupação da região desde a década de 1950. A rodovia PA 140 liga os município de Bujaru e Concórdia do Pará à rodovia Belém-Brasília, dentro do projeto de integração da região ao restante do país, construída durante o governo militar nos anos 1960 e parte do PIN Plano de Integração Nacional. 
De acordo com a senhora Maria das Graças, nascida em São Domingos do Guamá e uma das moradoras mais antigas da comunidade, sua família chegou à comunidade em 1975 . Ao explicar porque foram para Nova Esperança, ela relata:

[...] porque ele trabalhava [seu esposo] pra outra pessoa lá, então ele queria um lugar pra trabalhar assim, coisa dele né, e como essas terras estavam sendo loteadas, ou então a pessoa vinha e se apossavam, trocavam por alguma coisa ele conseguiu esse terreno aqui desse lado [...] ele se apossou [...] a pessoa chegava [...] porque muitas pessoas também né, que vinham de lá, inclusive os amigos dele, veio meu cunhado, veio, vieram algumas pessoas [...] aí o nosso terreno tirou [demarcou] aqui, o meu cunhado tirou mais lá na frente, o irmão do meu cunhado, meu cunhado tirou ali onde é o seu Getúlio, e muitos amigos de Bujaru também vieram pra cá [...] (informação pessoal) 80 .

As posses que eles "tiravam" eram de 250 metros de frente por 1.000 de fundo. Antes mesmo da chegada da senhora Maria das Graças, as terras já haviam sido apropriadas por outras pessoas de comunidades vizinhas, que plantavam principalmente pimenta-do-reino. Geralmente quem ficava nas posses eram trabalhadores destas pessoas. Muitas posses adquiridas naquela época estão hoje em mãos da empresa Biopalma, pois foram vendidos nos últimos três anos.

No período em que a senhora Maria das Graças chegou à localidade, em 1975, as pessoas se instalavam e plantavam a pimenta-do-reino. Quando este cultivo não dava mais certo, vendiam as posses e iam embora ou permaneciam nas terras plantando capim para o gado. Além da pimenta, cultivo principal da comunidade, também era possível encontrar arroz, mandioca, milho e feijão, e ainda criação de galinhas e porcos.

Já na década de 1970 os terrenos que compõem a comunidade hoje, de acordo com a senhora Maria das Graças, eram somente capoeira. Ela acredita que os moradores de Arapiranga, comunidade que dista aproximadamente $14 \mathrm{~km}$ de Nova Esperança, já haviam se utilizado da área para roças.

Quando as famílias precisavam ir para a cidade de Bujaru, pegavam carona em um caminhão que vinha do Município de Mãe do Rio, na Belém-Brasília, vendendo pão. O motorista dava a carona para que as pessoas também ajudassem a empurrar quando fosse necessário, pois o que hoje é rodovia na época era uma estrada vicinal, com muito buraco e lama. Somente no início da década de 1980 é que a empresa de ônibus Boa Esperança começou a fazer a linha Belém - Tomé-Açu.

\footnotetext{
${ }^{80}$ Maria das Graças Lopes Trindade, entrevista à autora em nov./2008.
} 
Segundo o senhor José Maria, que chegou em Nova Esperança em 1976, aquela localidade sempre foi uma área de migrante. O único que ele considera de lá mesmo é o senhor Manoel, mais conhecido como senhor Borracha. O senhor José Maria nasceu no município de São Domingos do Capim, mas cresceu na comunidade do Galho (que até então pertencia ao município de Capim, agora pertencendo ao município de Concórdia do Pará). Comprou a terra em que mora hoje, de um senhor chamado Lima Amaral, que já havia comprado de um outro senhor chamado Moisés.

Outro antigo morador é o senhor Boaventura. Também chegou em Nova Esperança na década de 1970, vindo, também ele, de São Domingos do Capim, mas os pais eram cearenses. Quando chegou, foi morar no fim da estrada vicinal que leva o seu nome (estrada vicinal do seu Boa, que antes não existia). Levavam a produção de milho, arroz, feijão e mandioca no cavalo para o km 29 (sentido Bujaru - Concórdia do Pará) para vender para os comerciantes locais. O caminho utilizado por ele não é o mesmo onde fizeram a rodovia. É uma estrada vicinal que fica paralela à rodovia, passando pelas comunidades Mariquita e Conceição. Também escoavam a produção por meio dos igarapés Cravo, Curuperé, e Arapiranga, todos afluentes da margem esquerda do rio Bujaru, sendo que os igarapés Cravo e Arapiranga chegam a atravessar a rodovia.

O senhor Boaventura chama os moradores que já moravam nas comunidades

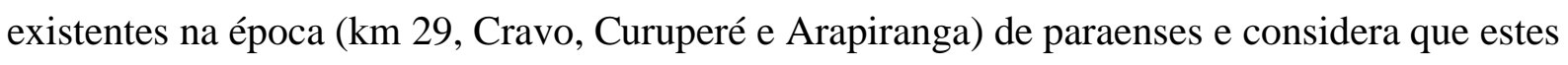
eram diferentes dos cearenses. Ele explica que os paraenses habitavam às margens dos igarapés, enquanto os cearenses, chamados de colonos, iam para o centro, ou seja, local que era cercado de mata. Conta que também tem vizinhos baianos. Essas pessoas começaram a vir para o local quando se iniciou a abertura da rodovia PA 140. Para lá também se dirigiram pessoas de municípios vizinhos como Benevides e Santa Isabel para comprar e morar nas terras no entorno da rodovia, pois estas já haviam sido apossadas por moradores das comunidades próximas.

Todo esse movimento de ocupação acabou por originar o que hoje é a comunidade Nova Esperança. Os camponeses que lá residem criaram a Associação de Produtores Rurais Nova Esperança (ASPRUNE), fundada em 2006. Ela surge com o objetivo de organizar a produção dos associados para comercializar com a Companhia Nacional de Abastecimento (CONAB). Em 2008, eram cerca de 25 associados, sendo praticamente a metade de mulheres, pois geralmente é o casal que se associa. Para entrar na associação a pessoa tem que ser da comunidade e, como diz o senhor José Maria, "ser pequeno agricultor familiar". A associação conta com o apoio da EMATER e desenvolve atividades como produção de muda, apicultura, 
horta, polpa de fruta, piscicultura, e há ainda planos de iniciar a avicultura. O presidente da associação considera que os associados participam bem, pois poucos faltam às reuniões, mas ao mesmo tempo diz que muitos associados não participam dos grupos de produção, o que considera a principal dificuldade da associação.

Existe também uma grande atuação do Sindicato de Trabalhadores e Trabalhadoras Rurais de Concórdia do Pará na comunidade, sendo a presidente uma das moradoras da comunidade. Esta atuação foi mais intensa principalmente quando foi preciso discutir sobre a regularização das terras da comunidade como remanescente de quilombo.

Em relação à Igreja, esta comunidade está vinculada à igreja São Pedro, de Concórdia do Pará, que também pertence à Diocese de Abaetetuba. A CEB foi fundada há dez anos, possuindo uma diretoria, a catequese e o grupo de evangelização. Às vezes, os moradores fazem um bingo nestes encontros de evangelização para angariar fundos para a construção da igreja e, enquanto a igreja está em obras, eles realizam seus cultos todos os domingos pela manhã na antiga igreja de madeira.

O movimento de mulheres de Concórdia do Pará tem algumas participantes da comunidade que formaram um grupo de mulheres com o objetivo de desenvolver alguma atividade que pudesse gerar renda para as famílias envolvidas. O grupo tentou trabalhar com a confecção de bijuteria, mas não deu certo, o que gerou o afastamento de algumas mulheres. $\mathrm{O}$ próximo passo foi trabalhar com canteiro de mudas de açaí, pupunha e pimenta. Para esta segunda atividade somente quatro mulheres tomaram a iniciativa e incluíram os seus maridos para ajudar. O canteiro funciona na posse de uma delas que fica na rodovia, onde foi possível colocar uma placa indicando a venda das mudas.

Nova Esperança não difere das demais comunidades estudadas em termos de infraestrutura. Como não existe o serviço de abastecimento de água, a construção de poço é a alternativa encontrada pelos moradores para obterem a água para ser utilizada na propriedade. Geralmente ele fica próximo à casa, facilitando assim o seu uso. Para facilitar a retirada da água do poço, algumas famílias possuem bomba d'água, o que facilita o encanamento da água, que pode assim ser levada para as cozinhas e banheiros. Existem também os igarapés que atravessam algumas posses e que também são usados por algumas famílias para o banho, lavar louça e nos trabalhos da posse.

$\mathrm{O}$ atendimento médico que recebem as famílias ocorre na comunidade vizinha chamada Curuperé, que dista cerca de $7 \mathrm{~km}$ de Nova Esperança. Lá existe um posto de saúde construído pela prefeitura de Concórdia do Pará que possui uma sala com equipamentos para tratamento dentário, outra para o clínico e uma pequena sala de recepção. Em dias pré- 
determinados vão um clínico e um dentista. Nos casos de urgência ou de outros especialistas, as famílias se dirigem a Concórdia do Pará, Bujaru ou Belém. Em Nova Esperança existe um prédio que foi construído em 2008 para funcionar como posto de saúde, mas ainda não foi ativado.

Na própria comunidade, a possibilidade de tratamento de algum problema de saúde pode ocorrer por meio do uso de plantas medicinais. Quem tem um conhecimento reconhecido do potencial de cura dos remédios naturais na comunidade Nova Esperança é a senhora Santina, mais conhecida como dona Sante. Ela é curadeira, benzedeira e parteira, e já foi responsável por muitos partos de mulheres de várias comunidades ao longo de sua vida (Foto 20 e 21).

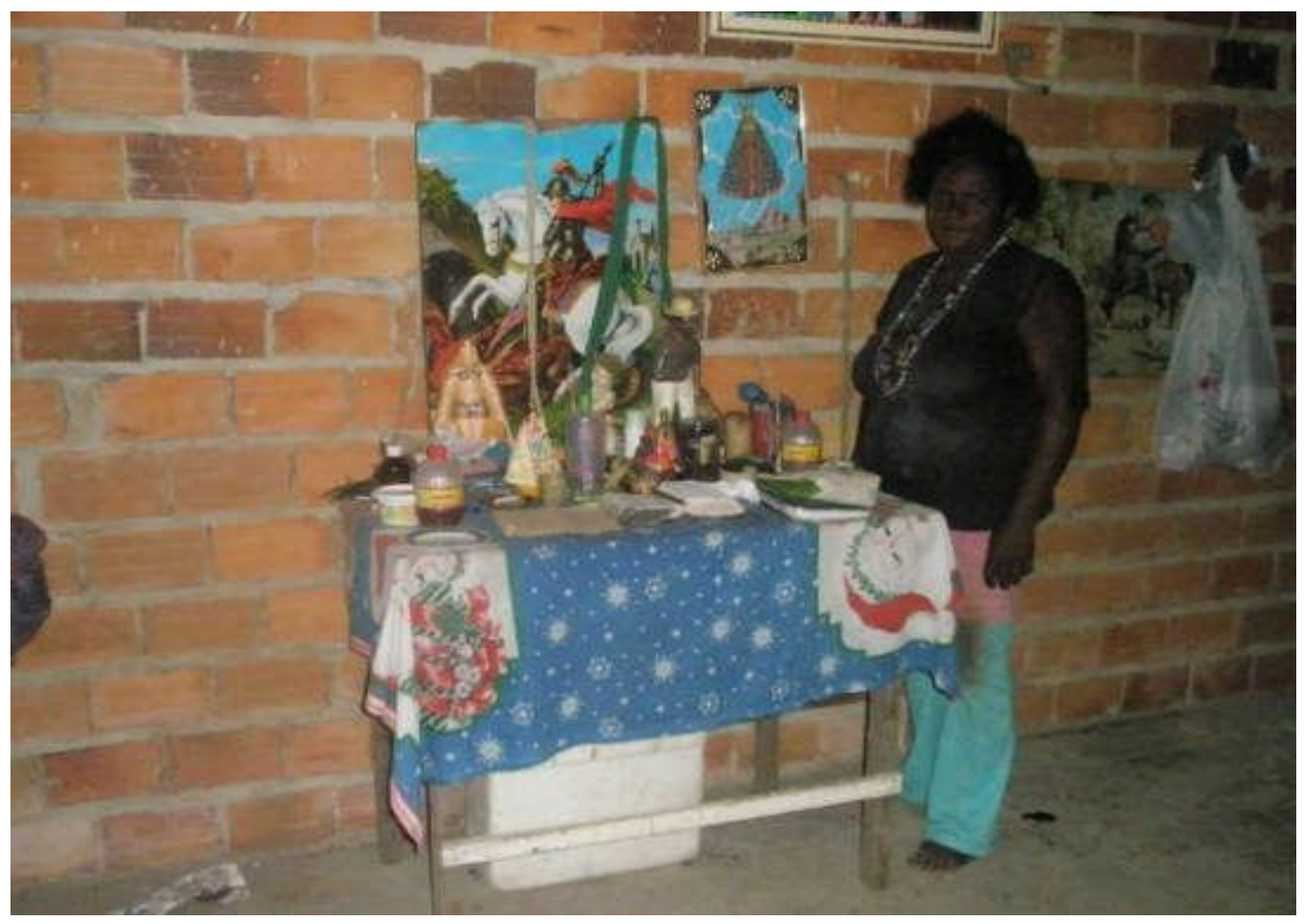

Foto 20: Senhora Sante no quarto onde atende os clientes, diante de seu altar (foto da autora em dez./2008). 


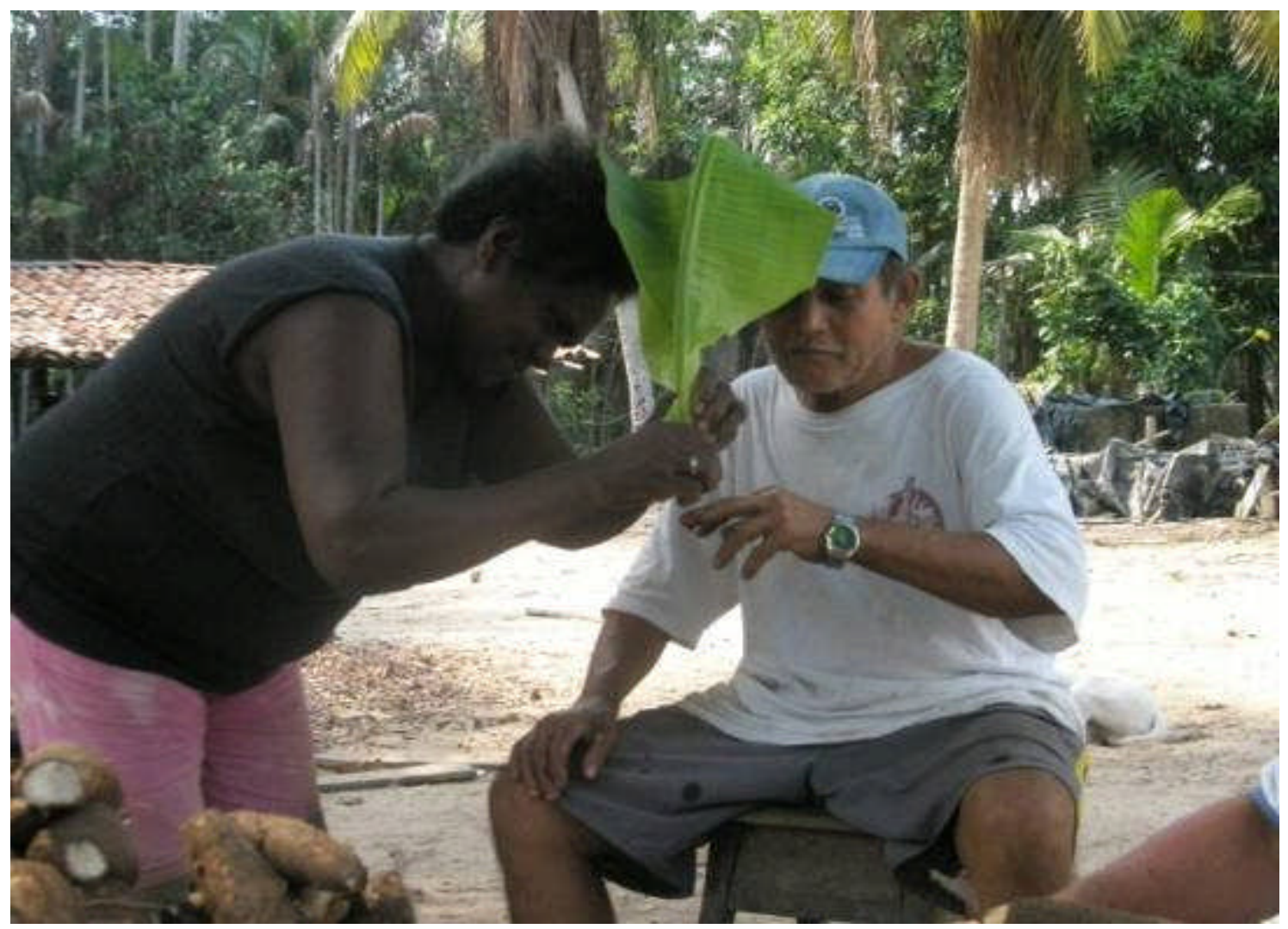

Foto 21: A senhora Sante cuidando de um corte no dedo do esposo com leite da folha de bananeira. Esse corte foi causado na hora em que ele raspava mandioca. Ao fundo, as várias plantas que ela tem em seu sítio: açaizeiros e mangueiras (foto da autora em nov./2008).

Serviço público de telefonia não existe, somente alguns poucos moradores possuem telefone celular que funciona por meio de antenas instaladas em cima ou ao lado das casas. Isto é possível também porque praticamente toda a comunidade já possui luz elétrica, instalada ao longo da rodovia desde a década de 1990. Porém, nas três estradas vicinais que partem da rodovia e cortam a comunidade, a luz elétrica foi instalada somente em 2008.

Em relação ao transporte, de todas as comunidades estudadas, Nova Esperança é a mais privilegiada. Na comunidade passam dois ônibus que fazem linha entre várias comunidades, como Perpétuo Socorro, Cravo, Curuperé e Curuperezinho, e a cidade de Concórdia do Pará. Dependendo da distância da comunidade, o valor da passagem varia de $\mathrm{R} \$ 2,00$ a $\mathrm{R} \$ 5,00$. Estes ônibus fazem viagem todos os dias, com exceção dos domingos. Passam na comunidade aproximadamente às 6:20 quando vão no sentido Concórdia do Pará e, quando voltam no sentido comunidades, passam por Nova Esperança por volta das 11:00.

As famílias vão à cidade comprar remédios, roupas, calçados, pagar contas, ir ao hospital ou receber os salários da prefeitura, aposentadoria e do programa bolsa família. É em Concórdia do Pará que também compram os mantimentos para o mês, principalmente porque existe somente um pequeno comércio e um bar na comunidade. Além destes comerciantes 
existem os chamados marreteiros. Estes são caminhoneiros que passam para somente comprar a farinha de mandioca que é vendida na feira do município de Marituba, na região metropolitana de Belém.

Quando as famílias vão a Belém, esperam às margens da rodovia os ônibus que fazem a linha Tomé-Açu - Belém ou Concórdia do Pará - Belém, da empresa Boa Esperança. São linhas que funcionam diariamente, inclusive aos domingos. Além destes ônibus existem diversas vans e microônibus que também fazem o mesmo trajeto. Os moradores de Nova Esperança pegam estes ônibus da empresa Boa Esperança na própria comunidade, pois a PA 140 (por onde trafegam estes ônibus) atravessa a comunidade, gastando assim cerca de três horas para chegarem a Belém.

Os alunos também contam com o serviço de transporte escolar da prefeitura de Concórdia do Pará. Como já foi dito, ao passarem para a quinta série eles devem se dirigir ou para a cidade de Concórdia do Pará, onde funciona o Sistema Regular de Ensino, ou para a comunidade Cravo, onde está a escola João Braga de Cristo que oferece da alfabetização até a quarta série através do sistema Multisseriado e da $5^{\mathrm{a}}$ série ao $3^{\circ}$ ano do ensino médio através do Sistema Modular de Ensino, atendendo diversas comunidades em seu entorno. A comunidade Cravo dista cerca de $8 \mathrm{~km}$ da comunidade Nova Esperança, sendo $5 \mathrm{~km}$ pela rodovia PA 140 e três em uma estrada vicinal denominada "ramal do Cravo". Em Nova Esperança existem duas escolas que possuem da alfabetização até a quarta série do ensino fundamental.

Sobre o lazer, Nova Esperança possui diversas alternativas. Lá existem dois times de futebol, um feminino e um masculino, uma quadra de areia e um campo. Os jogos ocorrem geralmente aos sábados à tarde na comunidade, entre os moradores, ou com um time visitante. Também pode ocorrer de um time da comunidade se deslocar para outras comunidades para jogar.

Outra forma de diversão é o bilhar, em um bar que existe na comunidade ou nos bares que ficam na comunidade vizinha Perpétuo Socorro. Nestes espaços, muitos se reúnem para beber, jogar e escutar música. Outra alternativa são os dois balneários existentes na comunidade Cravo. Eles são mais freqüentados no mês de julho, em razão das férias escolares que permitem a chegada de muitos parentes e amigos que vêm principalmente de Belém, mas também dos municípios de Ananindeua e Marituba. O local onde foi construída a ponte sobre o igarapé Cravo, na PA 140, também é um ponto que já foi muito agitado antes da formação dos dois balneários da Comunidade Cravo, mas ainda serve de referência para o lazer. Outra alternativa observada em Nova Esperança são os passeios para as praias de água salgada do 
Pará. Os interessados fretam um ônibus e dividem as despesas do transporte. Não é uma prática muito freqüente a realização destes passeios durante o ano. Além destas alternativas existentes para o lazer dos moradores da comunidade, existe aquela que traz pessoas das comunidades mais distantes: são as festas de brega ou "dançantes", com grandes aparelhagens de som que vêm de Belém, nos mesmos moldes já citados para as comunidades Campo Verde e Jutaí-Mirim.

O mês de junho é, na comunidade, um mês esperado pelos jovens. É o mês das festas juninas, momento em que eles apresentam a quadrilha junina à qual se dedicam em ensaios semanais desde o início do ano. Este ano o nome da quadrilha é Cheiro da Juventude. Estas quadrilhas organizadas em algumas comunidades contaram em $2010^{81}$, com o apoio da prefeitura de Concórdia do Pará, que oferece o tecido para a roupa dos dançarinos, o coreógrafo e o ônibus que leva os membros das quadrilhas (os brincantes) para participarem dos concursos de quadrilhas roceiras e o concurso de quadrilhas modernas organizados pela prefeitura. Para os outros materiais de que elas precisam, os coordenadores de cada quadrilha buscam patrocinadores, organizam festas e bingos de modo a angariar recursos e adquirir o que for necessário. A coordenação das quadrilhas é composta por um presidente, um vicepresidente, dois coordenadores e secretária.

No aspecto religioso, diferentemente de Jutaí-Mirim e Campo Verde, Nova Esperança ainda não escolheu seu santo padroeiro, apesar da comunidade religiosa estar organizada há $10 \operatorname{anos}^{82}$, por isso não existe a festa do padroeiro. A diretoria da comunidade realiza somente as novenas do mês de maio, o Mês de Maria, e as novenas do Natal. Nestas novenas eles também fazem rifas para angariar fundos e ajudar na construção da igreja. Fora estes dias também realizam o Domingo Alegre ${ }^{83}$ e festas dançantes para angariar fundos para as obras da igreja.

\subsubsection{A religiosidade camponesa}

É bastante visível nas três comunidades estudadas a organização das mesmas em torno da Igreja e de seus santos e santas. Além destas festividades comunitárias, outras duas atraem

\footnotetext{
${ }^{81}$ Não temos referencia sobre o referido apoio para outros anos.

${ }^{82}$ Uma comunidade organizada significa ter uma diretoria.

${ }^{83}$ É um dia em que eram realizadas atividades de lazer para as famílias e não possui data certa para ocorrer
} 
os moradores. Uma delas é a festa de Santa Ana, na vila de Sant'Anna, que se realiza no mês de julho, festa tão antiga quanto a igreja do século XVIII. A outra, que apesar de não ser do local também mobiliza as pessoas, é a festa do Círio de Nossa Senhora de Nazaré, em Belém, no segundo domingo de outubro. Esta ida a Belém está muito relacionada às promessas feitas e que precisam ser pagas.

A veneração ao santo padroeiro e a realização de romarias, de acordo com Moura (1986), são práticas que se difundem por toda a sociedade, mobilizando um grande número de pessoas. A religião do camponês baseia-se em duas faces de uma dívida para com a divindade que ocorre de forma direta e intensa: uma é a que o leva até a castigar a imagem do santo quando há omissão e não atendimento por parte do mesmo em relação aos pedidos realizados; a outra face desta dívida é a preocupação do camponês em cumprir a promessa feita, materializada em orações e bens ofertados em gratidão às graças recebidas, temendo um castigo se assim não agir.

De acordo com Moura (1986, p. 22), nessas práticas religiosas há um conteúdo que se insinua efetivamente camponês: "ele parece estar na forma de diferenciar, socialmente, os dias comuns dos dias especiais". O que dá sentido a esses dias especiais são os santos e as divindades. Uma data qualquer, um feriado nacional, não altera a substância simbólica do tempo como ocorre num dia de festejo do santo padroeiro, capaz de alterar o cotidiano nas áreas rurais, mesmo que não esteja no calendário nacional.

Estas comunidades religiosas, para iniciarem suas atividades, tiveram que contar com a iniciativa de alguns moradores que já detinham algum conhecimento sobre orações e cânticos. Foi o que aconteceu na comunidade Campo Verde, onde a comunidade religiosa se iniciou, segundo o senhor Miguel, a partir da experiência do seu avô e do seu pai. O senhor Miguel lembra que viajavam uma hora e meia de montaria (pequena canoa) para chegar à comunidade Arapiranga para participarem do encontro do grupo de evangelização de lá. A primeira missa em Campo Verde foi realizada há aproximadamente vinte cinco anos.

Para cada processo existencial do camponês, ou seja, nascer, viver e morrer, existem concepções e práticas que tentam prevalecer sobre as práticas e regras da sociedade que o envolve e domina. É o que acontece com suas concepções religiosas. Muitas vezes o camponês se dirige à divindade sem a mediação da igreja oficial, apenas por meio de um membro da comunidade que detém um saber religioso reconhecido pelos demais e que é eficaz nos momentos de dor ou de ameaça social. O peso da religião é maior na cultura simbólica camponesa "[...] porque fornece uma explicação cheia de sentidos e de sinais para quem observa diariamente o mistério da terra, da água e do ar, bem como a incompetência dos 
poderes seculares para atender às necessidades inerentes ao seu modo de vida" (MOURA, 1986, p. 22).

Além das festividades, encontramos ao mesmo tempo, de forma periférica, a presença da religiosidade africana e da pajelança. De acordo com Moura (1986), a religião cria formas e fórmulas que atendam os membros do grupo, e ao mesmo tempo recria a perpetua formas e fórmulas mais antigas de orar, explicar e venerar a divindade. Mesmo esquecidas ou banidas pela igreja oficial, continuam a desempenhar um papel que dá sentido ao cotidiano da vida camponesa. Um exemplo disto é a prática de "rezar" as pessoas, que tem a finalidade de afastar uma influência nefasta que incide sobre a mente ou o corpo de uma pessoa. Este é o caso da senhora Sante em Nova Esperança, parteira e benzedeira da comunidade, procurada inclusive por pessoas de outros lugares com esta finalidade.

\subsubsection{As Comunidades Eclesiais de Base}

O termo comunidade é bastante corriqueiro nas falas dos moradores de Jutaí-Mirim, Campo Verde e Nova Esperança. Das falas se observa que este termo possui um caráter administrativo, religioso, político e territorial.

$\mathrm{Na}$ dimensão religiosa e administrativa, segundo os presidentes ou coordenadores locais da Igreja, as comunidades são divisões territoriais e administrativas cujo objetivo é organizar e tornar mais eficaz a administração da Igreja Católica, ou seja, são unidades locais através das quais a Igreja Católica se constitui e marca sua presença. A comunidade surge, para as próprias famílias, quando elas começam a se reunir para realizar as orações, as novenas e cantar a ladainha de casa em casa. Para a Igreja Católica, ela surge quando estas famílias pedem que sejam reconhecidas como comunidade católica e entram com um processo para este reconhecimento. Com o reconhecimento oficial, são formados diversos grupos (evangelização, catequese, dízimo, jovens, etc.) e uma diretoria ou coordenação da comunidade religiosa reconhecida, cuja materialização ocorre com a construção da igreja e da Barraca da Santa, também chamado Salão Paroquial, mesmo que a comunidade ainda não tenha definido quem vai ser o santo ou a santa padroeira. O membro da comunidade é aquele que participa desta comunidade religiosa, mesmo que não vá muito ao culto. 
A dimensão política desta mesma comunidade religiosa aparece quando, nos próprios encontros religiosos nas casas dos camponeses ou na igreja, além dos momentos de oração, também são discutidos os problemas que as famílias vivenciam e são buscadas soluções para os mesmos. Neste sentido, um membro da comunidade não precisa ser da religião católica, mas se ele mora naquele povoado e participa de outros momentos vivenciados pelas famílias e de outras formas de organização social que não a religiosa, será considerado também um membro da comunidade. Esta dimensão começou a aparecer de forma significativa a partir da década de 1960, com a criação das Comunidades Eclesiais de Base (CEBs).

Assim, o território da comunidade foi se definindo a partir da participação religiosa/política das famílias que habitam determinado povoado. É um território marcado fortemente por relações de parentesco, compadrio e vizinhança entre as famílias, relações que permitem uma certa coesão entre elas, o que não evita, é claro, divergências de opinião. Assim, quem faz parte do território da comunidade é quem vivencia estas relações, é quem participa das questões políticas e religiosas que envolvem as famílias, ainda que não dê a mesma importância para essas questões ou que não participe efetivamente da vida religiosa (católica) da comunidade.

Sendo assim, nesta perspectiva, a comunidade é praticamente sinônimo de povoado. De acordo com Almeida (2006), por mais que não haja uma correspondência exata entre os povoados, produto da agregação, e as comunidades que os articulam segundo diferentes planos de organização social, pode-se afirmar, guardadas as distinções, que se tratam de situações passíveis de aproximação. Para ele, os povoados consistem em realidades empiricamente observáveis, enquanto que as comunidades compreendem relações sociais como vizinhança, situação comum de interesses, identidade e formas de ação comum que podem ser lidas como relações comunitárias.

Como já citado, esta relação entre religião e política que conformam um território tem sua origem na formação das Comunidades Eclesiais de Base (CEBs). Foram as orientações seguidas por alguns padres e religiosas que assumiram a paróquia de Bujaru a partir do final dos anos 1960 a 1980 que estimularam a constituição das Comunidades Eclesiais de Base e, com isso, marcaram a abertura para a relação entre Igreja Católica e os diversos movimentos sociais e associações que surgiram desde então, como o Movimento das Mulheres Transformadoras do Campo e da Cidade de Bujaru (MMTCCB), cuja repercussão continua sendo notada nos dias atuais em algumas comunidades, como por exemplo Campo Verde, através dos Grupos de Mulheres (COSTA, R., 2008). 
De acordo com Betto (1986), as CEBs são pequenos grupos organizados em torno da paróquia (urbana) ou da capela (rural), animados pelos chamados agentes pastorais e criados por iniciativas de leigos, padres ou bispos. Há controvérsias sobre onde surgiram as primeiras CEBs: alguns pesquisadores afirmam que foi em Nísia Floresta, arquidiocese de Natal, outros que foi em Volta Redonda. Todos porém concordam que isso ocorreu na década de 1960. Nas cidades estas comunidades podem estar distribuídas em pequenos grupos, enquanto que na zona rural podem formar um único "grupão" com a reunião das pessoas numa capela aos domingos para a celebração do culto.

Essa reunião de pessoas é denominada comunidade porque se juntam pessoas que têm a mesma fé, pertencem à mesma Igreja e moram na mesma região. Estas pessoas, motivadas pela fé, vivem uma comum-união em torno de seus problemas. São eclesiais porque são congregadas na Igreja, como núcleos básicos de comunidade de fé. São de base porque são integradas por pessoas que trabalham com as próprias mãos (BETTO, 1986).

Foi no campo que as CEBs mais proliferaram. Era na Igreja que posseiros, seringueiros, trabalhadores assalariados, arrendatários, indígenas, etc. encontravam seu principal referencial ideológico. Com o apoio da Comissão Pastoral da Terra, o homem do campo aprendeu a denunciar os conflitos e agressões sofridas, assim como a articular-se para a retomada de diversos sindicatos rurais atrelados à política oficial do governo (BETTO, 1986).

As CEBs são de natureza religiosa e possuem um caráter pastoral. Orientam-se pelo método ver-julgar-agir, método que parte da realidade e que busca suprimir a dualidade févida encontrada em muitos grupos cristãos. Elas são políticas no sentido de serem um espaço de expressão da palavra do oprimido, onde emerge a consciência crítica do povo à ordem social injusta (BETTO, 1986). Outros subsídios utilizado pelas CEBs eram os Círculos Bíblicos, criados por Frei Carlos Mesters. São folhetos em linguagem popular, onde os fatos da vida são comparados aos da Bíblia. Através dessa prática, a comunidade passa a entender a sua história como uma história de libertação e a buscar as verdadeiras raízes dos males sociais (BETTO, 1986).

A ação das CEBs dá-se de modo intra-eclesial, através da celebração de culto, festas litúrgicas, novenas, catequese, preparação aos sacramentos, estudos de documentos da Igreja, e de modo extra-eclesial, através da vinculação às lutas populares, na cidade e no campo (BETTO, 1986). As CEBs são a matriz da Teologia da Libertação, que nasceu da prática das CEBs no esforço de viverem as suas lutas sociais à luz da fé cristã. Elas favoreceram a criação 
de uma nova perspectiva teológica para a Igreja, de reflexão da fé a partir do lugar do pobre e do oprimido (BETTO, 1997).

De acordo com Souza (2008), desde as primeiras comunidades cristãs, narradas nas epístolas paulinas, fala-se de comunitarismo. Toda a experiência de difusão do cristianismo passa pela experiência das comunidades. A Igreja Católica identificou no Comunitarismo uma forma de valorização das ações sociais e coletivas e um meio de ação política. No Concílio Vaticano II (1962-1965), temas como a volta às fontes, a dessacralização e o comunitarismo receberam destaque especial. O comunitarismo manifesta-se pela importância crescente dada aos grupos: colegiados, assembléias, equipes, associações e reuniões de todo o gênero, até as chamadas Comunidades Eclesiais de Base.

Para o autor, a fundação da Conferência Nacional dos Bispos do Brasil (CNBB) em 1952 foi o marco para a construção do comunitarismo cristão no Brasil. Nessa época a CNBB recebia, além das influências das primeiras comunidades cristãs, o impacto de pensadores cristãos como Jacques Maritain e Emmanuel Mounier. Os bispos e sacerdotes incentivavam o protagonismo do laicato na formação de grupos de reflexão comunitária, círculos bíblicos, etc. Esses movimentos foram o germe que se desenvolveu em formas mais sistemáticas e orgânicas de pensamento e ação teológica, derivando na Teologia da Libertação.

Com o processo de abertura política no Brasil, a Igreja deixou de ser o único canal para os que não tinham como expressar seus problemas. As CEBs já não eram mais o espaço privilegiado de organização popular e seus membros passaram a participar de outras formas autônomas de mobilização (BETTO, 1986). Na década de 1990, as CEBs sofreram um forte refluxo devido à política do Vaticano de valorizar movimentos espiritualistas em detrimento dos movimentos com dimensão social e política (BETTO, 1997). A irradiação dos núcleos pentecostais evangélicos e da renovação carismática católica é apontada por Teixeira (2005) como uma explicação para o refluxo de que trata Betto. Para Teixeira, a relação das CEBs com os pentecostais não está desprovida de tensões ou conflitos localizados, e é vista como um desafio para o processo de inserção das CEBs no mundo religioso plural e na ampliação de sua acolhida ecumênica e inter-religiosa.

Os temas do ecumenismo e do diálogo inter-religioso têm aparecido nos últimos encontros intereclesiais das $\mathrm{CEBs}^{84}$. Durante o IX Intereclesial, ocorrido em 1997, um dos blocos temáticos tratou justamente da questão do diálogo com os pentecostais e carismáticos

\footnotetext{
${ }^{84}$ A experiência dos encontros intereclesiais das CEBs nasceu no ano de 1975, visando uma maior articulação das comunidades espalhadas pelo Brasil. A experiência ganhou continuidade nos anos seguintes, expressando a riqueza e a vitalidade das comunidades (TEIXEIRA, 2005).
} 
católicos. Sublinhou-se o desafio da busca da convivência cotidiana e do exercício do diálogo comum nas ações e lutas concretas a favor do povo. Estes temas foram retomados no $\mathrm{X}$ Intereclesial, em 2000. A presença cada vez mais incisiva das religiões afro-brasileiras e da questão indígena tem provocado nas CEBs o desafio de uma reflexão alternativa sobre a inculturação que tem sido compreendida não como mera adaptação, mas como uma interpretação criadora (TEIXEIRA, 2005). Para Domezi (2006) e Teixeira (2005), os Encontros Intereclesiais das CEBs são uma expressão da vivacidade das comunidades.

Uma outra questão, sobre o refluxo das CEBs, destacada por Betto (1997), é o processo de paroquialização das comunidades. Às vezes, a paróquia quer absorvê-las, outras quer marginalizá-las. É uma tendência, por parte de bispos e vigários, no sentido de reduzir as CEBs a um movimento paroquial, o que faz com que elas percam toda a mística que faz com que consigam quebrar os dualismos tradicionais dentro da Igreja, como a separação entre fé e política, entre povo e hierarquia, etc. A paroquialização das comunidades, inclusive, traria consequiências também para a atuação dos movimentos sociais, refreando essa irradiação que elas possuem como alavanca desses movimentos.

Outros desafios apontados por Betto (1997) são o fortalecimento dos movimentos populares, sindicais e políticos; a ação com vistas a tratar melhor a questão do negro, do índio e da mulher; a realização de um trabalho de massa; o resgate das expressões da religiosidade popular, como procissões, romarias e vias-sacras; o trabalho com a mídia, tanto a mídia constituída quanto aquela ainda a ser criada pelas próprias comunidades. Segundo o autor, nada disso estava sendo bem trabalhado. É por isso que o tema sobre o trabalho de massa estava na pauta do encontro de São Luís em 1997 (BETTO, 1997).

De acordo com Betto, para que se possa sair dessa crise, os bispos têm que pensar numa Igreja voltada para o Brasil, incorporando os valores que eles pregam: a opção pelos pobres, a inculturação, a libertação, a superação da crise da modernidade. Por sua vez, as CEBs têm que voltar a ativar os seus mecanismos de auto-formação, de aprofundamento bíblico, litúrgico e espiritual e, ao mesmo tempo, a sua consciência política (BETTO, 1997).

É preciso encontrar o equilíbrio entre as três pontas do triângulo: a formação bíblica e pastoral, a formação política e a formação mística. Se conseguirmos isso, vamos ter uma Igreja que nasce dos pobres pelo Espírito de Deus, extremamente expressiva e preparando um modelo de Igreja para o Brasil em vista do terceiro milênio (BETTO, 1997, p.6).

Domezi (2006) aponta outros problemas/desafios: a migração de membros qualificados e a manipulação de comunidades por parte de partidos e movimentos políticos, embora se tratem de casos isolados; a diferenciação interna das CEBs; os descompassos entre 
estas e a massa dos católicos; os conflitos entre lideranças e o conjunto da comunidade, e a relação da politização com a espiritualidade.

Apesar destes desafios, para Domezi (2006) as CEBs continuavam vivas e atuantes, embora em alguns casos tenha ocorrido uma perda das características atribuídas a elas por conta dos desafios enfrentados, como os citados acima. Teixeira (2005) considerou ser aquele momento não uma crise das CEBs, mas uma retomada de sua inserção social e eclesial a partir dos novos desafios.

Os novos desafios para as CEBs foram discutidos no XII encontro, realizado em 2009, em Porto Velho/Rondônia, que teve como tema principal "Ecologia e Missão" e como lema "Do Ventre da Terra, o Grito que vem da Amazônia".

A Carta final do encontro convoca a todos para o trabalho político de base, para a militância em movimentos sociais e partidos ligados às lutas populares; para participar nas lutas por políticas públicas ligadas à educação, saúde, moradia, transporte, saneamento básico, emprego, reforma agrária e para tomar parte nos conselhos de cidadania, nas pastorais sociais, no movimento pela não redução da maioridade penal, no Grito dos Excluídos, nas iniciativas do $1^{\circ}$ de Maio e das Semanas Sociais.

Neste encontro, que contou com a presença do presidente e do vice presidente da CNBB, os bispos exprimiram o desejo de que todos os padres do Brasil renovassem o compromisso de acompanhar as CEBs (CNBB, 2009). Esta postura dos bispos tem sua origem na V Conferência Geral do Episcopado Latino-americano e do Caribe, ou Conferência de Aparecida, ocorrida em 2007 e onde, segundo Comblin (2008), decidiu-se voltar ao método de Medellín e Puebla, ou seja, ao esquema ver-julgar-agir da Ação Católica. Essa continuidade com Medellín e Puebla manifesta-se, sobretudo, em dois temas fundamentais: a opção pelos pobres e as comunidades eclesiais de base. São justamente dois temas que, em outros tempos, foram muito atacados ou tratados com indiferença, como coisas do passado. $\mathrm{O}$ documento originado desta conferência usa duas vezes a palavra "libertação", antes proibida, ainda que matizada pelas adjetivações "autêntica" ou "integral".

O documento conclusivo da conferência fala explicitamente das CEBs. Essa é a parte do documento que sofreu mais correções em Roma, pois o texto dos bispos era muito mais incisivo. Assim mesmo, o texto final enuncia todos os frutos positivos das comunidades de base, reconhecendo que elas foram o sinal da opção pelos pobres e que não puderam desenvolver-se como deveriam devido à oposição realizada por vários bispos em diferentes locais do país. Agora estes bispos querem levantar essas restrições e dar vida nova a essas comunidades pobres (COMBLIN, 2008). 


\subsubsection{A organização do trabalho e da produção nas três comunidades}

A unidade básica de trabalho destas famílias camponesas é a sua posse. Nele está o sítio, local onde fica a casa da família; o centro, onde fica a roça, e o retiro, onde fica a casa de farinha, uma espécie de fábrica doméstica. Todos são espaços de trabalho e socialização entre homens, mulheres, crianças, jovens e adultos, mas com suas devidas especificidades. Todavia, existem duas situações em que a morada não fica na mesma posse em que fica o centro: a primeira é quando a família fica no único pedaço de terra que conseguiu comprar e que só é suficiente para morar (neste caso, se utiliza do centro e do retiro do parente); a segunda é quando a família possui uma posse onde fica o centro e o retiro, porém esta posse fica distante de uma via de circulação, como uma estrada vicinal, uma rodovia, ou um igarapé navegável. Neste caso, a família, encontrando possibilidades, deixa de morar na posse para construir uma casa em um pedaço de terra cedido por parentes que moram às margens destas vias, mas continuam indo trabalhar na sua própria posse. Isto ocorre para facilitar o acesso à estrada vicinal ou rodovia e, com isso, à cidade, principalmente para os filhos que lá estudam.

O sítio é o espaço de responsabilidade da mulher. Nele, geralmente, estão: casa, poço, banheiro, pomar, chiqueiro, galinheiro (com galinhas, patos, perus), a casa de ferramentas onde às vezes existe um forno à lenha. No sítio também encontramos as plantas medicinais como: mastruz, cidreira, anador, hortelã, arruda, catinga de mulata, cravinho de defunto, manjerona, etc. As mulheres acordam no mesmo horário que os homens, às vezes até mais cedo, mas antes de irem para o centro - onde realizam o plantio, a capina e a colheita precisam cuidar do café da manhã e da merenda que irão levar para o local de trabalho. Antes do almoço, ou voltam para casa, ou fazem o almoço em um fogaréu improvisado. À tarde também voltam mais cedo para casa para fazer o jantar, carregar água, lavar o que for preciso. Quando a família precisa fazer a farinha de mandioca, a mulher também vai para o retiro, onde está localizada a casa de farinha.

O centro é de responsabilidade do homem, local onde fica a roça, base de sustentação econômica das famílias. O tamanho da roça varia de uma até dez tarefas ( $25 \mathrm{~m}^{2}$ cada tarefa), dependendo do número de membros da família que possam trabalhar e da necessidade familiar. Fazer uma roça é um trabalho demorado, que depende do tamanho da área, da mãode-obra disponível, do tipo de produto cultivado e do ritmo da natureza. Primeiro é necessário esperar que cessem as chuvas, o que ocorre de meados de julho em diante, para fazer a broca, derruba, queima e por último a coivara, se precisar. Segundo o senhor Tomé, de Campo 
Verde, no momento do preparo da terra têm algumas mulheres que fazem a broca, mas a derruba do capoeirão não, esse é trabalho que só os homens fazem. Depois do preparo da área, homens e mulheres trabalham juntos, sendo esse o momento de iniciar o plantio com o milho, se houver necessidade deste produto, e em seguida a maniva, o feijão e o arroz. São freqüentemente plantados em meio à maniva: jambu, maxixe, melancia e macaxeira. No tempo de cada produto a colheita é realizada, ficando somente a maniva que pode demorar de oito a treze meses, dependendo do tipo de mandioca e da necessidade familiar. Depois de realizar o plantio duas ou três vezes na mesma roça é necessário deixá-la por mais ou menos cinco a seis anos para que haja a regeneração da vegetação e seja possível cultivá-la novamente. Nesse ínterim é necessário utilizar outra parcela da posse para repetir o mesmo procedimento, ou seja, há um rodízio das terras cultivadas. $\mathrm{O}$ trabalho na roça é feito somente por uma família (só os pais ou pais e filhos solteiros), por um conjunto de famílias ligadas por laços de parentesco (pais com filhos solteiros e filhos casados, ou dois irmãos casados, ou tio e sobrinho, etc.), ou por um conjunto de famílias ligadas por laços de amizade e de vizinhança.

Uma experiência de trabalho que, aparentemente, não é muito comum é a que um grupo de cinco pessoas (alguns solteiros e outros casados) resolveu fazer na comunidade Nova Esperança. Prepararam uma área de terra na posse de um deles e fizeram uma roça comunitária só com a mandioca, ou seja, a roça pertence a todos e todas as etapas, desde a derrubada da capoeira até a produção da farinha, foram realizadas por todos. No final, a farinha foi dividida igualmente entre os cinco integrantes do grupo para que a comercialização fosse feita separadamente, ou seja, cada um vendeu a farinha para o comerciante que desejou.

Essa prática não é considerada comum por dois motivos: porque o trabalho na roça é geralmente feito pela família, ou seja, os que trabalham possuem um laço de parentesco entre os membros, o que não ocorreu com este grupo; e porque o que os diferencia da forma como geralmente as outras famílias trabalham é justamente a divisão igualitária do produto final: a farinha. O que geralmente ocorre é que quando duas famílias trabalham juntas, elas dividem a área da roça para cada família já no momento de preparação da área para o plantio. Esta divisão pode ser igual ou não, portanto, a quantidade de farinha produzida conjuntamente, pode ser ou não a mesma para cada família.

No trabalho da roça muitas vezes são duas famílias que trabalham conjuntamente: uma é a dona da roça e a outra é a que foi ajudar (que pode ser a família do cunhado, do "cumpadre" ou do vizinho). A ajuda mútua foi percebida sendo praticada mais entre parentes e sob a forma de troca de dia (Fotos 22 e 23). 


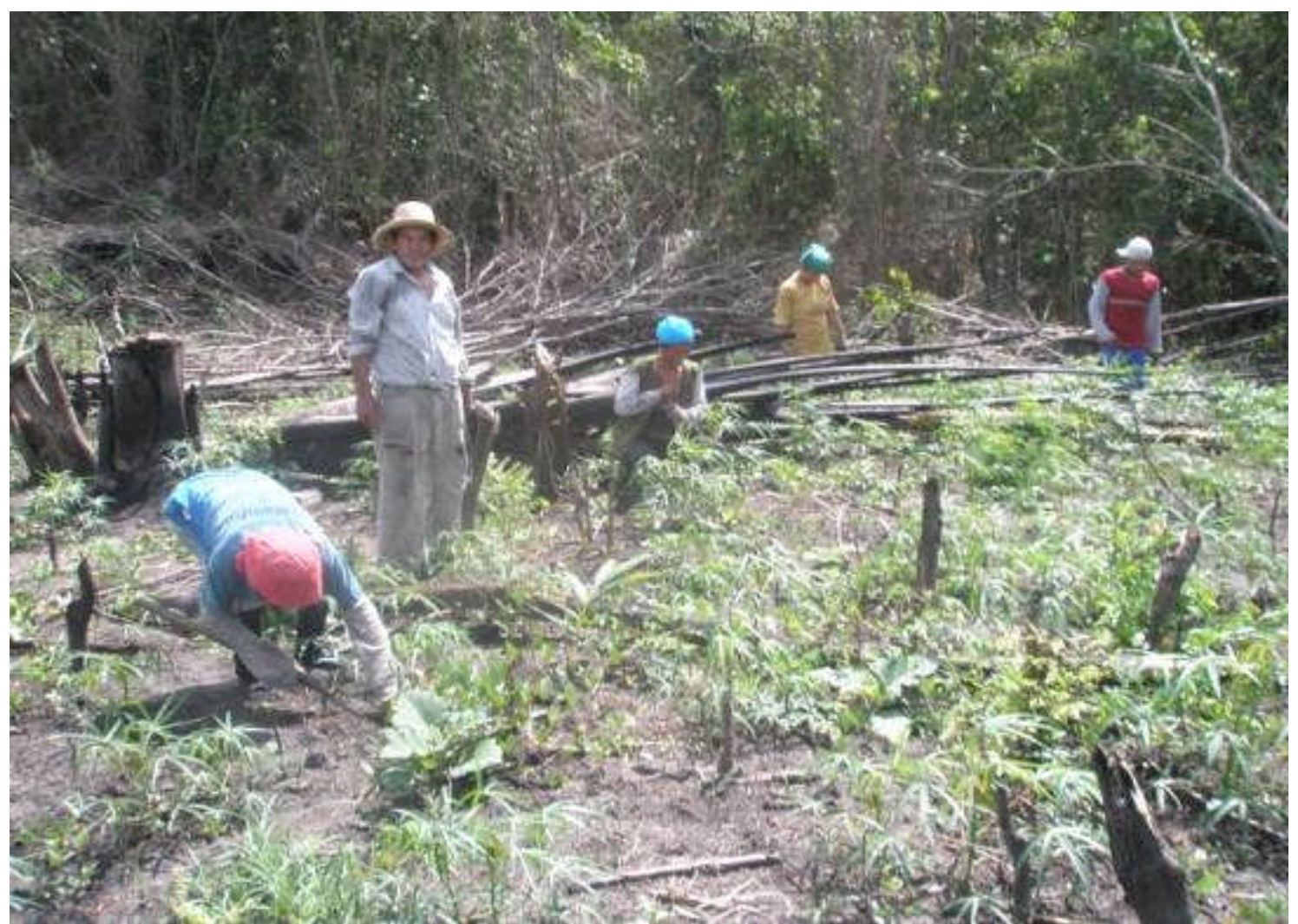

Foto 22: Capina da roça: trabalho sendo realizado por membros de três famílias, na roça que pertence somente a apenas uma delas. Este é um exemplo de ajuda mútua que ocorre na comunidade Campo Verde (foto da autora em dez. /2008).

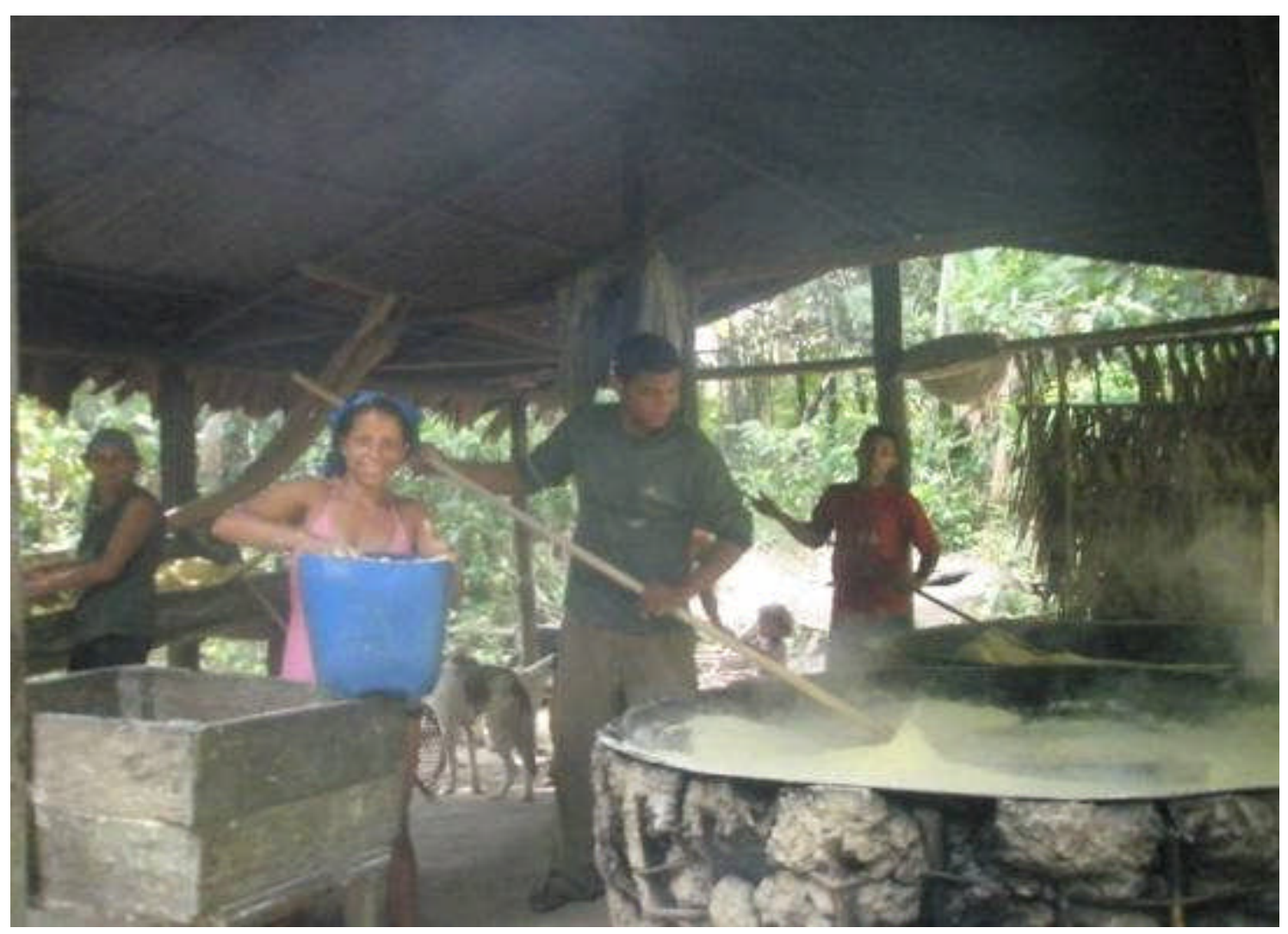

Foto 23: A farinha sendo produzida por membros de três famílias, mas pertence somente a uma família. O que ocorre aqui é a ajuda mútua por meio da troca de dias (foto da autora em dez. 12008). 
Ao se fazer a roça, já se estabelece se a área da roça é de todos ou se será dividida entre cada interessado. A divisão é da área da roça, e não do trabalho. Todos trabalham em toda a área da roça, independente se ela está dividida ou não. Este trabalho comum pode ser desde a derrubada da capoeira para o preparo da área à produção da farinha.

Nos relatos sobre mutirão se fala muito no passado, mas enfatizam que hoje em dia ainda existe, ainda que em menor quantidade. No caso de Nova Esperança foi organizado um mutirão para ajudar na construção do telhado da igreja e também ajudar quando alguém precisa ou por estar doente ou por precisar viajar.

Quanto às crianças, as que têm acima de seis anos geralmente estudam, e no período em que não estão nas aulas acompanham seus pais nas tarefas do dia-a-dia. Esse acompanhar tem um significado importante, pois elas observam o que os pais fazem, ou no centro ou em casa, e nas brincadeiras reproduzem e aprendem o trabalho. Conforme a idade, principalmente entrando na adolescência, as crianças vão desempenhando pequenas tarefas como levar o almoço ao centro, se a roça for próxima do sítio, geralmente os meninos é que fazem isso, ou se menina, lavar a louça, carregar água onde não há água encanada, fazer pequenas tarefas em casa ajudando a mãe. No retiro geralmente ajudam a raspar a mandioca ou a tirá-la da água quando fica de molho (Foto 24).

A roça também pode ser feita só pelo filho solteiro, que com ajuda de colegas, primos ou irmãos, "toca" a roça com o objetivo de comprar algo para uso pessoal, que pode ser desde uma roupa, um calçado ou uma bicicleta ${ }^{85}$.

\footnotetext{
${ }^{85} \mathrm{Na}$ comunidade Nova Esperança ocorreu o caso de um garoto de 12 anos que fez uma pequena roça para comprar as coisas que ele queria.
} 


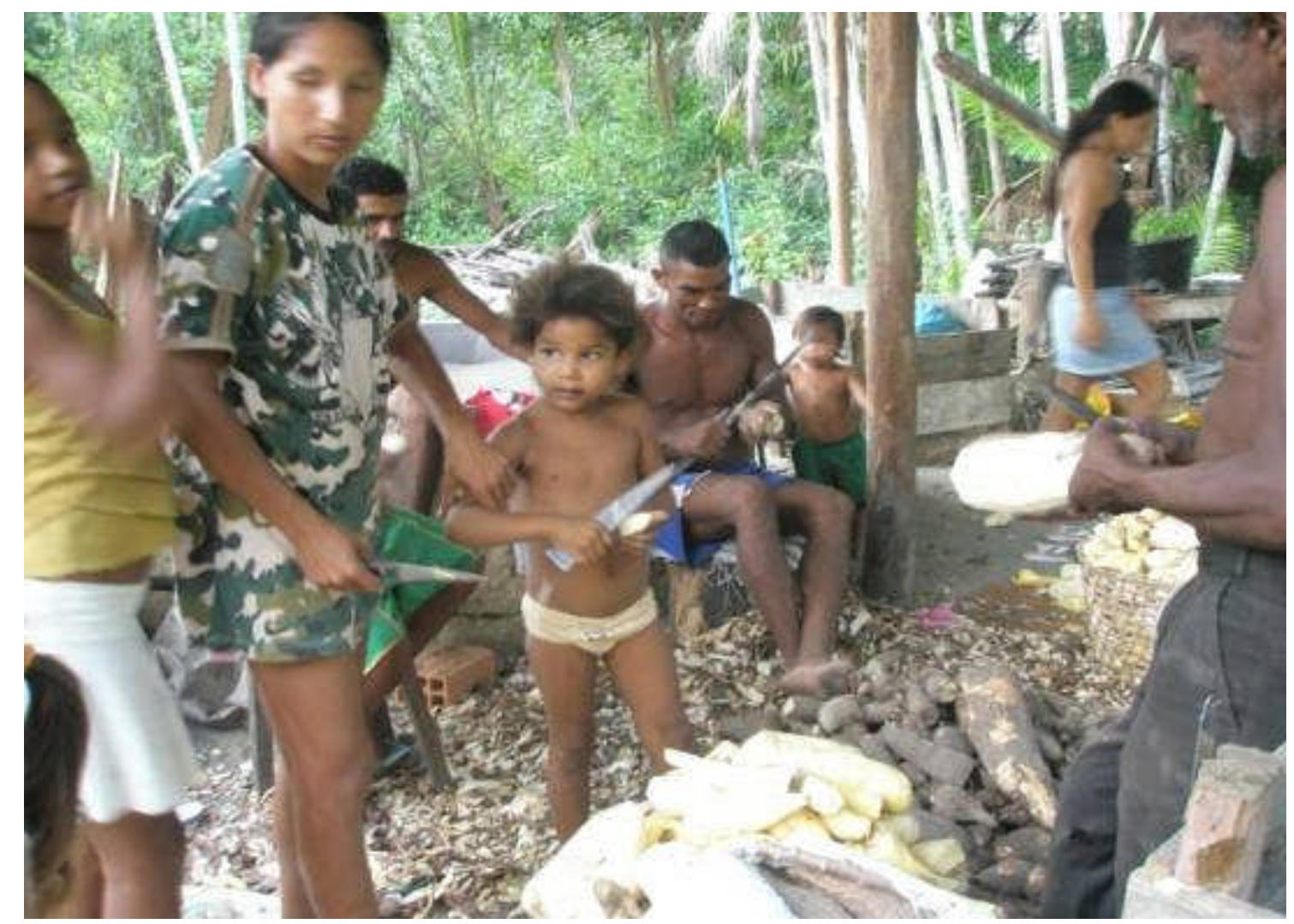

Foto 24: Em Nova Esperança, a criança na casa de farinha raspando a mandioca, única atividade que ela teria capacidade de realizar, mesmo que brincando (foto da autora em out. /2008).

De acordo com Tavares dos Santos (1978), a socialização é um elemento estrutural da produção camponesa. O trabalho passa a fazer parte do mundo infantil, o que faz com que a criança internalize a sua importância como meio da ganhar a vida e passe a vivenciar, por meio da aprendizagem e da participação na força de trabalho familiar, a exploração do camponês.

$\mathrm{Na}$ unidade camponesa a força de trabalho é utilizada de acordo com o valor de uso que possui, não sendo realizada a separação do trabalho da pessoa do trabalhador e nem a conversão desta força em mercadoria. Cada pessoa desenvolve um trabalho que é útil e concreto, mas somente de acordo com sua capacidade e a necessidade da família. É esta necessidade que também permite a coexistência muitas vezes deste trabalho familiar com a ajuda mútua, o trabalho acessório e o assalariado (TAVARES DOS SANTOS, 1978).

Em relação ao trabalho acessório, ele é muito presente na comunidade Nova Esperança, onde existem muitos plantadores de pimenta-do-reino. Algumas famílias que não possuem pimental, ou que têm um pequeno, se dedicam à "apanha" de pimenta nas plantações dos vizinhos, nos meses de julho a setembro. Para isso, as famílias organizam seus trabalhos em suas roças para que, nestes meses, elas possam estar disponíveis. Desta forma, no período 
da "apanha" da pimenta suas roças de verão (janeiro) já estão maduras e não precisam mais ser limpas e as de inverno (agosto) já tiveram suas áreas preparadas antes de começar a atividade na pimenta. É o período, pois, de baixa intensidade de trabalho na unidade produtiva, o que permite que alguns membros da família se desloquem para trabalhar temporariamente nas áreas de cultivo dos vizinhos, propiciando-lhes uma renda complementar.

Vemos então, que a prioridade é o trabalho familiar na posse e, havendo necessidade do trabalho acessório, o trabalho familiar é reorganizado de maneira que a família ou um ou dois membros da família possam sair, sem prejudicar o trabalho na posse. Segundo Tavares dos Santos (1978) o trabalho acessório significa uma combinação técnica e econômica da força de trabalho familiar, que poderia ficar parcialmente ociosa caso não existisse este tipo de trabalho.

Existem alguns casos de, no máximo, duas famílias em cada comunidade, em que um membro é assalariado permanente em cargos públicos como professores, garis, serventes ou trabalhadores da Biovale ${ }^{86}$. Tratam-se, em todos os casos encontrados, do marido, da esposa ou de um filho(a) que contribuem para a renda familiar. Além desta renda a mais, existem outros rendimentos de origem governamental como aposentadoria, pensão por invalidez, bolsa família e bolsa trabalho, com os quais algumas famílias podem contar todos os meses. Esse dinheiro a mais, apesar de pouco, que entra na composição da renda familiar, pode ser investido na produção, no pagamento de diárias para outros trabalhadores, principalmente os aposentados quando não podem contar com a sua própria força de trabalho e nem com a dos filhos, ou na compra de um bem que pode trazer algum conforto para a família.

Cada uma das situações citadas - a ajuda mútua, o trabalho acessório, o assalariamento e as outras formas de vencimento - contribuem para que a unidade familiar camponesa se mantenha e se reproduza enquanto camponesa na medida em que busca, de acordo com suas possibilidades, as diversas alternativas de adquirir não só força de trabalho necessária para o trabalho na posse, mas com isso a melhoria de sua condição de vida enquanto camponês.

Assim, o trabalho na roça e no retiro expressa as relações que o camponês possui com a família, parentes e vizinhos. Há, porém, uma relação que ultrapassa estas outras: é a relação com a natureza, com o que está à sua volta. Assim, o plantio, quando realizado, não leva em consideração somente o período de sol ou de chuva, mas também as fases da lua, como relata senhor Tomé, da Comunidade Campo Verde:

\footnotetext{
${ }^{86}$ Eles são contratados para encher os saquinhos com a terra onde serão colocadas as mudas do dendê.
} 
[...] na época que não serve pra plantio não planta [...] mas mesmo com essa chuva que deu, pra mim ainda não presta pra plantá, porque a época da lua [...] a época da lua agora crescente não presta pra plantá nada [...], lua cheia também principalmente o milho não presta, dá broca e a broca devora $o$ milho e não presta [...] minguante e lua nova que planto, tem que esperar a lua lá pro dia 20 em diante presta pra fazé o plantio [...] a chuva prestô, valeu porque a gente tem a planta né, maniva né, maniva varando a terra como tenho ali plantado, valeu muito essa chuva, mas pra plantio não presta [...] (informação pessoal) ${ }^{87}$.

Sobre as fases da lua, a senhora Camila, da comunidade Perpétuo Socorro ${ }^{88}$, relatou que na passagem da lua minguante para a lua nova é melhor plantar "tudo que cresce fora da terra", por exemplo, milho, arroz e feijão. "Tudo que cresce dentro da terra" deve ser plantado na passagem da lua crescente para a lua cheia, como por exemplo, a mandioca. São nestas múltiplas relações entre os homens e entre eles e a natureza, que os camponeses destas comunidades buscam, na persistência do dia-a-dia, formas de permanecer no campo, na sua própria terra, de forma digna. Para isso, buscam aproveitar o que podem dos recursos que a terra oferece por meio do trabalho familiar.

Em seu trabalho na agricultura, os camponeses trabalham com culturas temporárias e permanentes. As culturas temporárias são plantadas na roça, começando pelo milho que é plantado em novembro e dezembro e é cultivado principalmente para o consumo das aves (ou dos bichos, como estas aves são chamadas) e da família que utiliza este cereal para o preparo de mingau, canjica, ou simplesmente assam ou cozinham o milho na espiga para comer. Geralmente o tipo de milho plantado é o Ibra, devido à exigência do mercado. Além deste tipo, também plantam o pontinha, ou comum, que possui maior durabilidade na roça. Uma técnica utilizada por estes camponeses é a de deixar o milho voltado para baixo, o que eles chamam de "quebrar a planta", pois assim o milho fica mais protegido do sol e da chuva e dura mais tempo na roça.

Quando o milho já está nascendo é plantada a maniva, principal plantio da roça, e o que demora mais para ser colhido (Foto 25). Quando o milho já começa a ser colhido, iniciase o plantio do feijão, no mês de junho. Segundo a senhora Camila, de Perpétuo Socorro, é "entre o Antônio e o João, [que] se planta o feijão" 89 . Segundo o senhor Laércio, da comunidade Nova Esperança, quando plantam o feijão, geralmente é do vermelho e é somente para a alimentação da família.

\footnotetext{
${ }^{87}$ Tomé Lopes de Oliveira, entrevista à autora em dez./2008.

${ }^{88}$ Senhora que visitei quando fui a Nova Esperança.

${ }^{89}$ Trata-se dos dias de Santo Antônio e São João.
} 


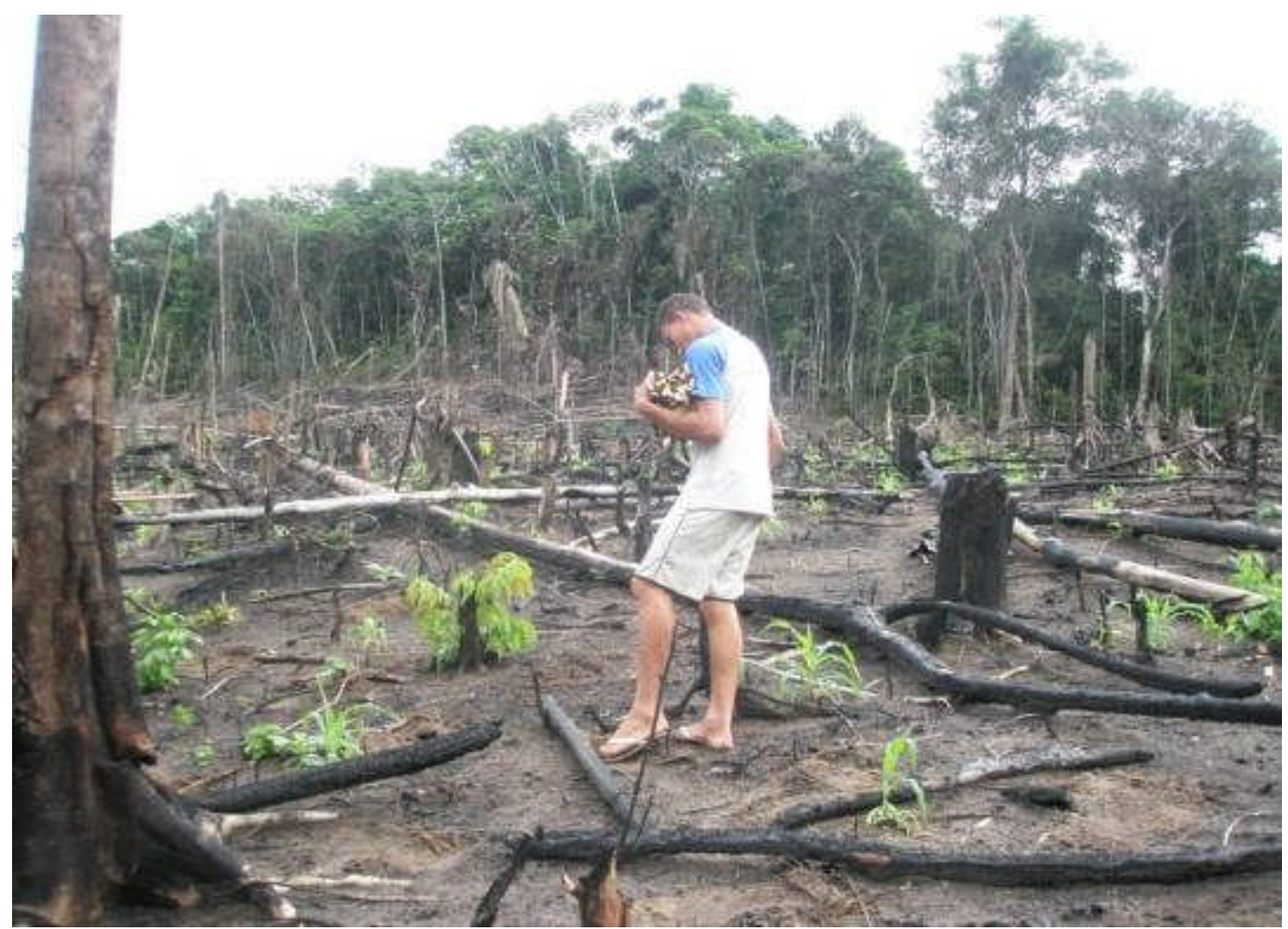

Foto 25: Roça onde está sendo plantada a maniva. O camponês está jogando a terra sobre a maniva que já está na cova. A roça não é dele, é do irmão, mas ele está ajudando. Ao fundo podemos observar a capoeira que precisou ser derrubada e queimada para se fazer esta roça, onde o milho já está crescendo (foto da autora em jan./2009).

O arroz é um outro cultivo realizado pelas famílias. Já teve seu tempo áureo nas décadas de 1930 a 1960 e agora são pouquíssimas as famílias que ainda plantam e, quando o fazem, é para o consumo familiar, só vendendo se houver um excedente. Os tipos cultivados são o agulhinha (mais plantado), agulhinha vermelho, saquarema, arroz vermelho, cano forte e mato grosso (Foto 26). 


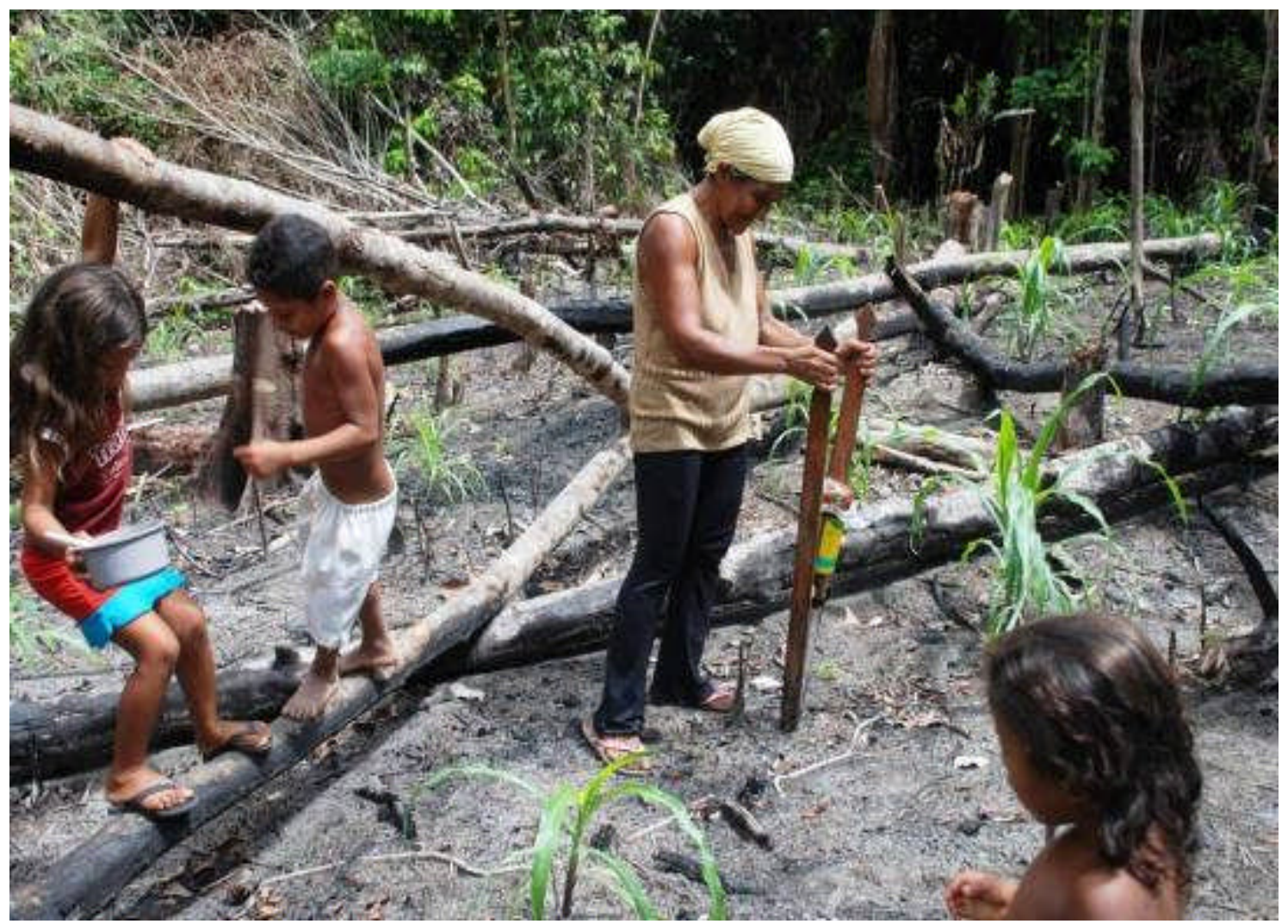

Foto 26: O plantio do arroz na comunidade Jutaí-Mirim (Valéria de Marcos em jan. 2010).

O calendário destes cultivos está representado na figura abaixo (Figura 2) 

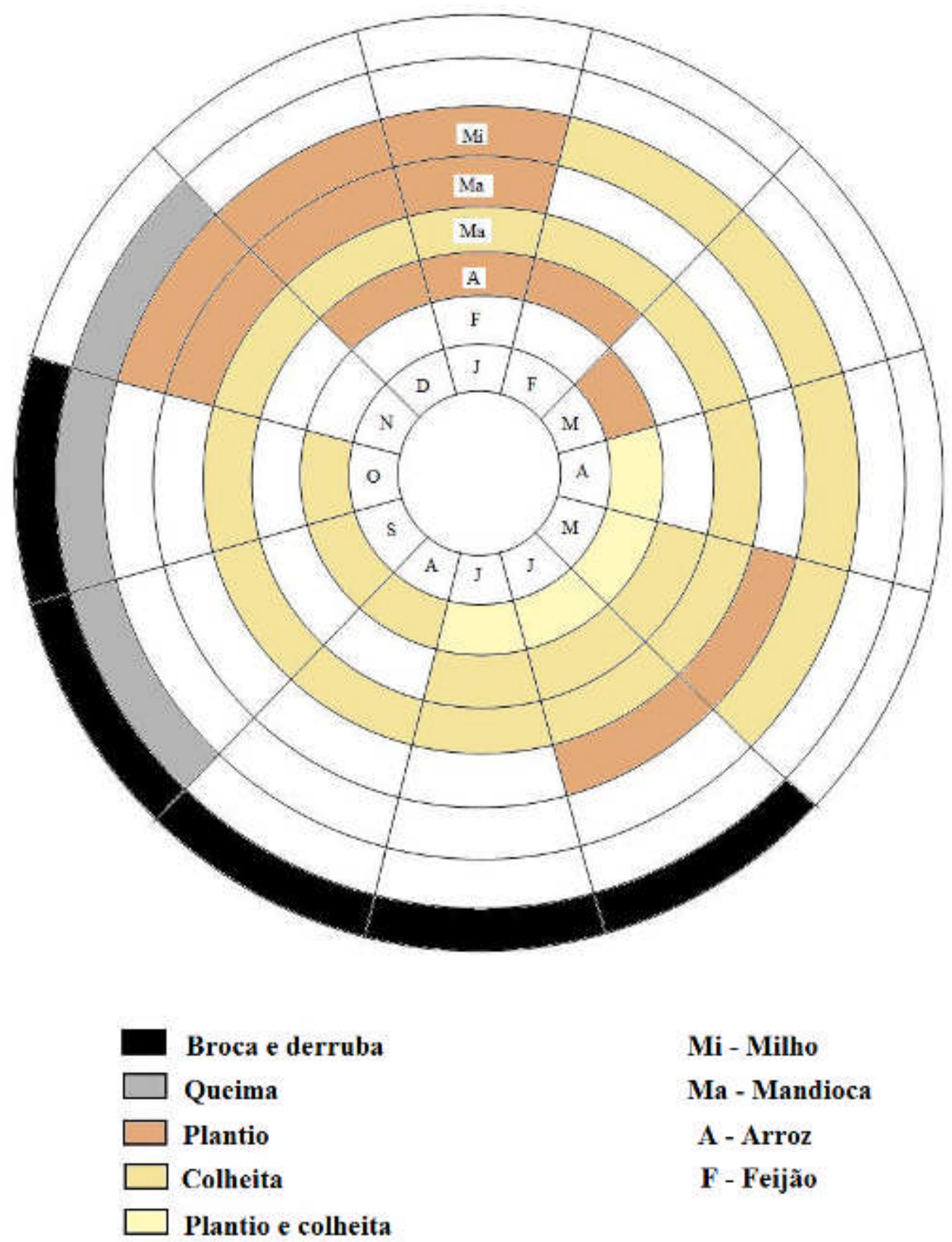

$$
\begin{aligned}
& \text { Mi - Milho } \\
& \text { Ma - Mandioca } \\
& \text { A - Arroz } \\
& \text { F - Feijão }
\end{aligned}
$$

Plantio e colheita

Figura 2: Calendário Agrícola.

Fonte: Trabalho de Campo

Organização: Rosiete Santana, 2009

Dentre estes cultivos destaca-se aqui o da mandioca, pela importância econômica que tem, principalmente para as famílias de Campo Verde e Jutaí-Mirim. Praticamente todas as famílias trabalham com este cultivo, sendo os tipos mais cultivados a Manduquinha, a Jacamim e a Tucumã. Geralmente eles não utilizam estes nomes, e sim apenas mandioca 
branca e mandioca amarela. Segundo Laércio, da comunidade Nova Esperança, na feira os consumidores procuram mais a amarela, pois quando é branca pensam que é macaxeira, não servindo então para acompanhar a comida. Segundo os camponeses a amarela é de melhor qualidade e vende mais. Além desta qualidade da mandioca, branca ou amarela, a mandioca pode ser da mole ou da dura. A mandioca mole é quando ela é colocada na água para ficar de molho para a produção da farinha, originando o que se denomina de farinha d'água. As famílias geralmente fazem farinha da mandioca mole, porque com a mandioca dura a farinha fica mais seca.

Além da farinha, outros produtos podem ser derivados da mandioca, principalmente quando ela não é colocada na água: o tucupi, usado para fazer molho ou cozinhar aves, principalmente o pato; a goma, usada para fazer a farinha de tapioca e a tapioquinha; a crueira $^{90}$, usada para fazer o mingau. Além disso, também pode ser feito o beijuxica ${ }^{91}$ e a farinha seca. Com a farinha já pronta pode-se fazer o mingau de farinha, que pode ser misturado com a castanha-do-pará ou açaí, o caribé ${ }^{92}$ e o chibé ${ }^{93}$.

O plantio da mandioca é realizado geralmente nos meses de dezembro e janeiro, com o objetivo de produzir a farinha. A produção da farinha é realizada no retiro, local onde fica a casa de farinha e que é de responsabilidade de toda a família. O retiro pode ficar no sítio ou no centro, e se houver um igarapé na posse, o ideal é que ele fique próximo ao igarapé, para facilitar o transporte da mandioca do igarapé para ele. Se não tem igarapé na posse, geralmente as famílias constroem um tanque ao lado da casa.

A casa de farinha é onde se produz a farinha, principal e, muitas vezes, o único produto comercial da maioria das famílias das comunidades (Foto 27). O trabalho para o preparo da farinha é dividido entre homens e mulheres. Os homens geralmente ficam no forno assando a farinha, pois é um trabalho muito cansativo. As mulheres cuidam das outros serviços como amassar, peneirar e prensar a massa da mandioca. Quando a mandioca é colocada em uma prensa e não no tipiti é o homem que faz este serviço, pois é uma tarefa mais pesada. Parece-me que o critério para a divisão do trabalho é a força física necessária para a realização do serviço.

\footnotetext{
${ }^{90}$ Resíduo da fabricação da farinha de mandioca que, por ser grosso, não passa na peneira.

${ }^{91}$ Um dos tipos de beiju (bolo feito de massa de mandioca ou de tapioca).

92 Mingau feito com farinha d'água bem fina. Diz a crença ser alimento forte, que reanima as forças, quando tomado, em especial, em jejum. Por isso é muito tomado pelas pessoas quando estão doentes.

${ }^{93}$ Pirão feito com água, farinha de mandioca e sal. Pode ser acompanhado por outro alimento, como carne e peixe.
} 


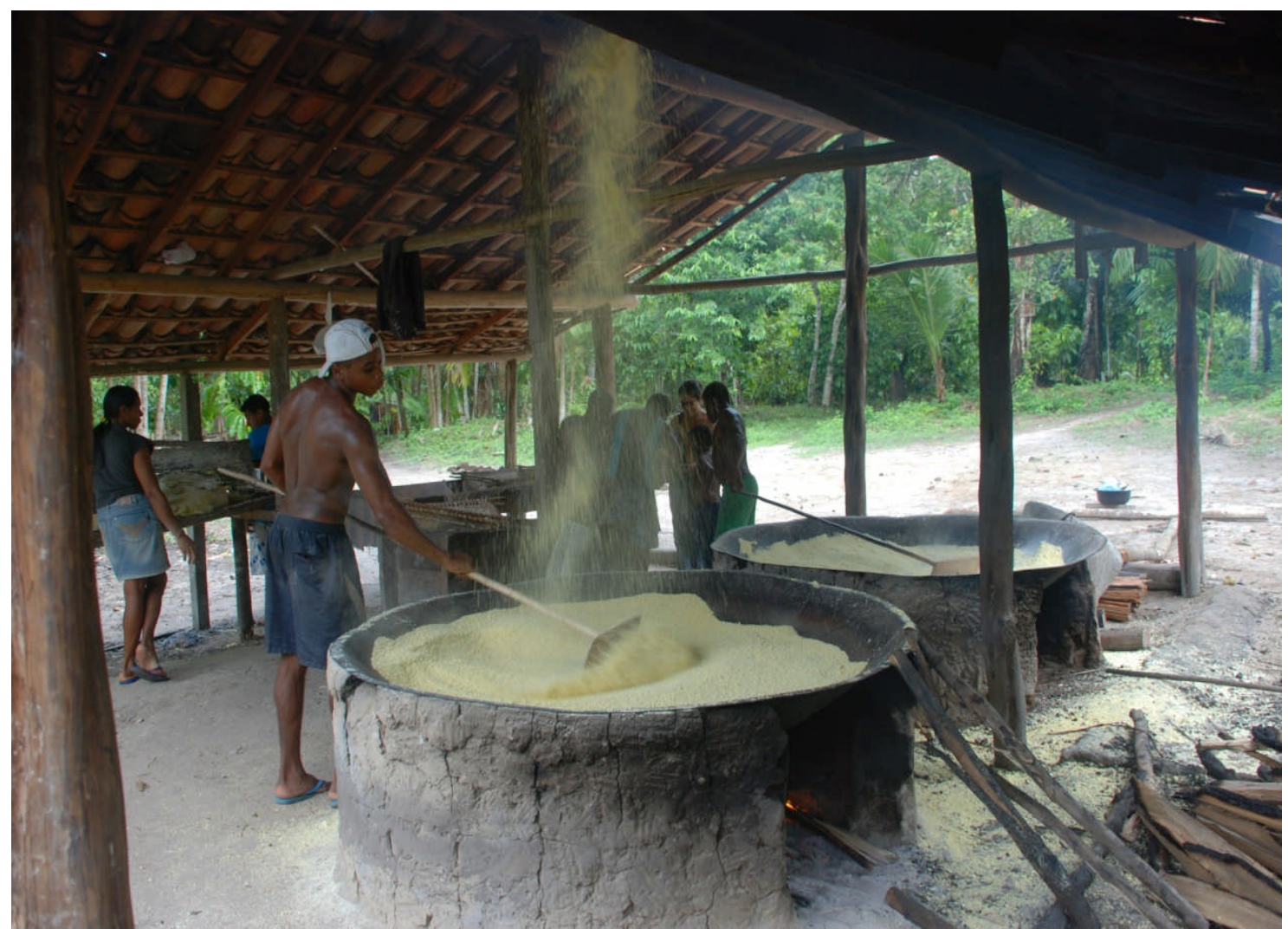

Foto 27: Jutaí-Mirim: casa de farinha. Da esquerda para a direita é a massadeira, a caixa de peneirar e os fornos (Valéria de Marcos em jan. 12010).

Na casa de farinha encontramos a concha/massadeira ou motor, o tipiti ou uma prensa, a peneira com a caixa onde deve ficar o que foi peneirado e o forno. O ideal é que cada membro da família fique responsável por um destes instrumentos para que se possa agilizar a produção da farinha. Esta produção é cansativa e demorada. Dependendo da quantidade que ser quer produzir, da força de trabalho disponível e do tipo de mandioca que será utilizada (se dura ou mole) pode demorar de um a cinco dias.

Esta produção ocorre da seguinte forma (Fluxograma 1): 


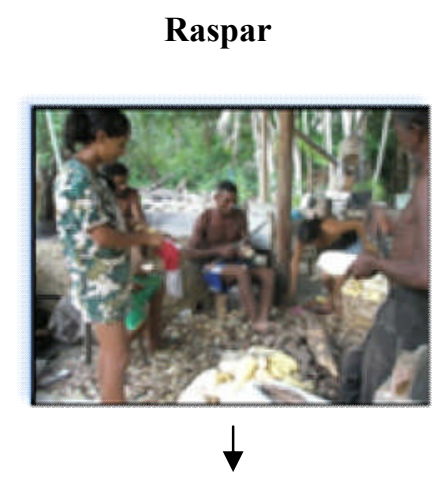

ou Deixar de molho

Ralar no ralo ou motor

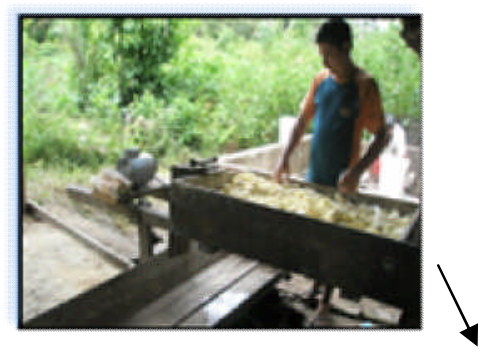

Amassar na concha/massadeira ou no igarapé
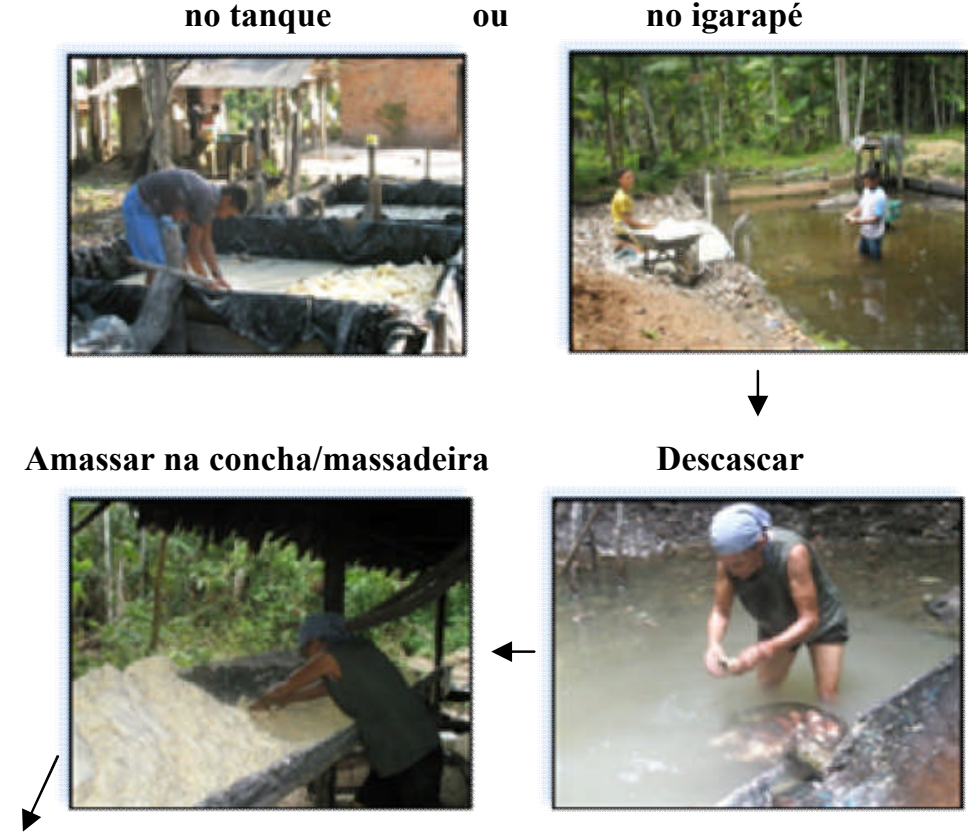

Prensar

na Prensa

ou

no Tipiti

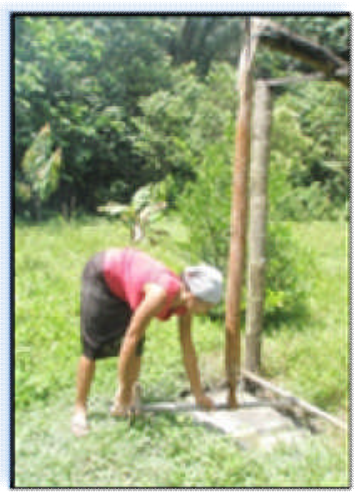

Peneirar

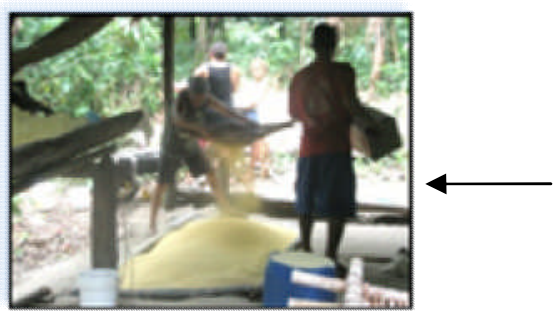

$\searrow$ no Forno

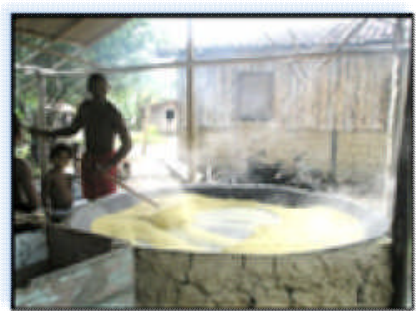

Embalar

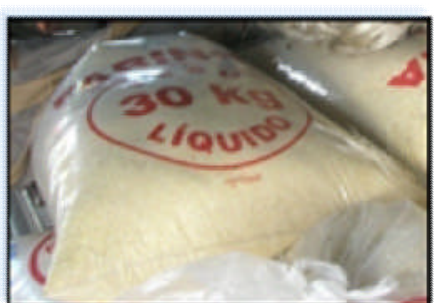

Peneirar

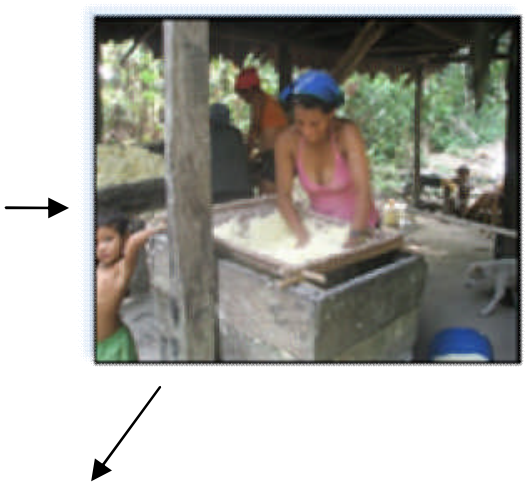

Assar

ou na Chapa

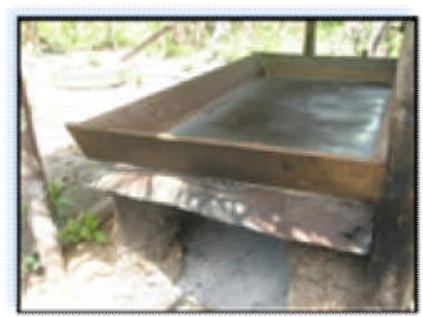


Uma prática observada entre as famílias é a meação. Quando uma família não tem condições de produzir a farinha por alguma eventualidade, ela se associa de "meia" ou de "metade" a outra família. Isto ocorre da seguinte maneira: a família que tem o plantio da mandioca entrega o mesmo para que outra família realize a colheita e produza a farinha. Esta, ao terminar a produção, entrega metade da farinha produzida para a família que possuía a roça de mandioca.

A comercialização da farinha ocorre na própria comunidade através dos marreteiros que passam comprando, ou em outros municípios. Neste último caso, pode ser feita pelo próprio produtor ou pelo marreteiro. Na comunidade Campo Verde os pacotes de farinha (com 30 quilos) geralmente são vendidos a um marreteiro e transportados por meio de caminhonete até o porto do assentamento Santa Maria, a aproximadamente dois quilômetros de distância. De lá seguem em barcos que vêm do alto Bujaru até os portos de Belém (porto da Conceição e do Ver-o-Peso) (Fotos 28 e 29). Estes barcos navegam no rio todas as quintasfeiras.

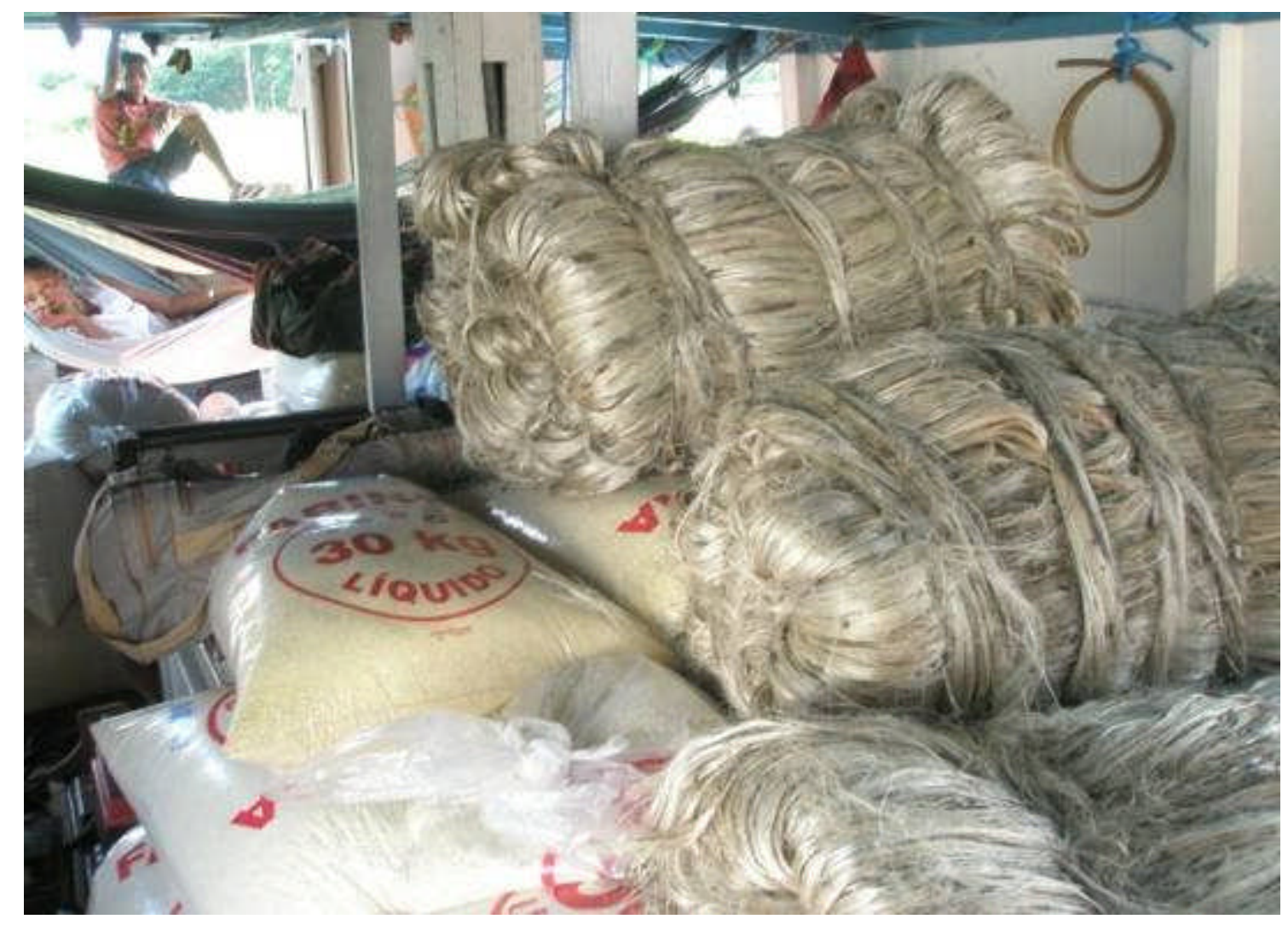

Foto 28: Dentro dos barcos, passageiros com suas redes disputam espaço com os pacotes de farinha e malva. Cada barco chega a carregar 700 pacotes de 30 quilos de farinha (foto da autora em out./2008). 


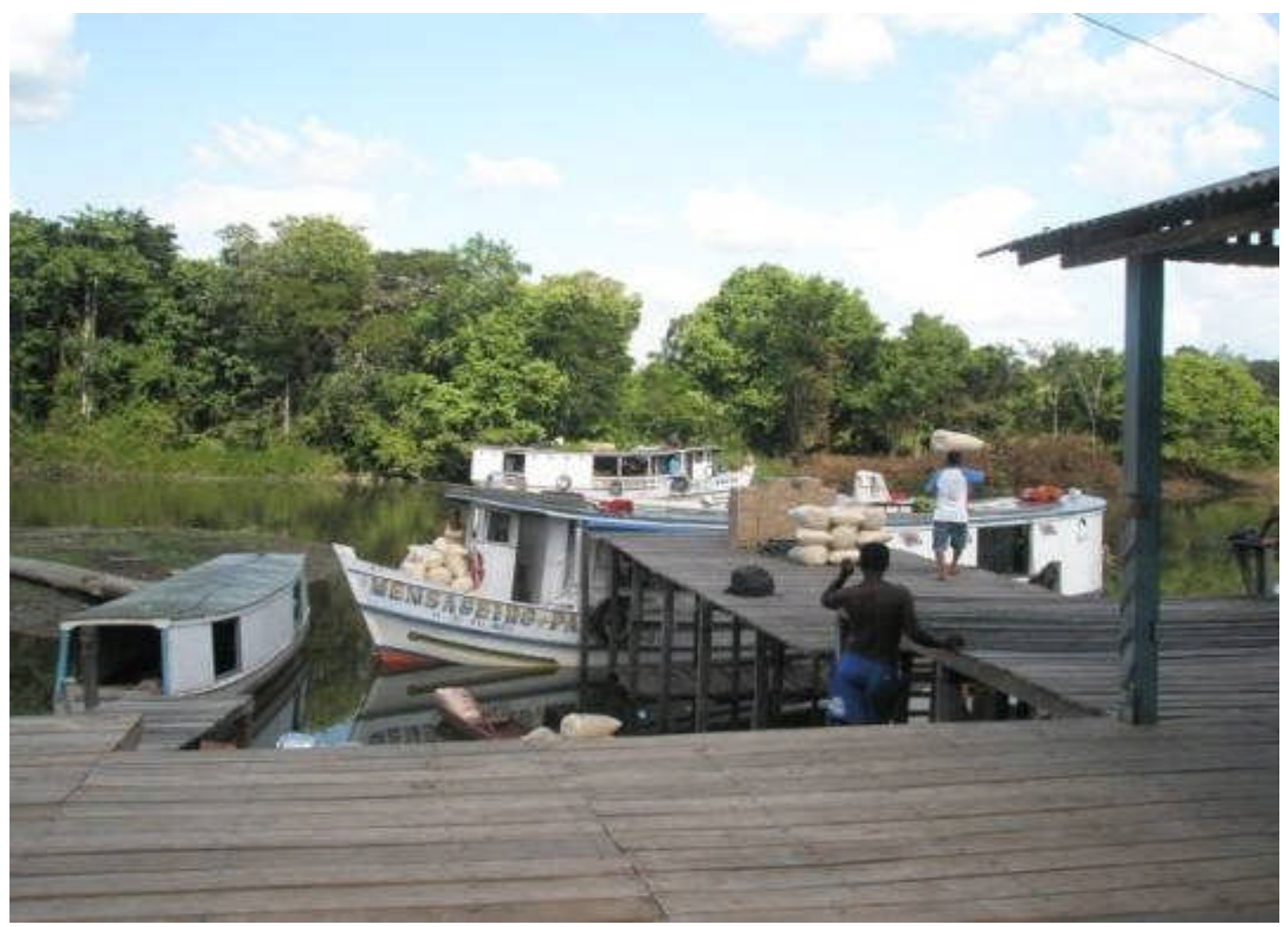

Foto 29: Porto da Foz do Cravo, local para onde se dirigem camponeses de diversas comunidades com seus pacotes de farinha para serem transportados pelos barcos até Belém (foto da autora em out./2008).

Os camponeses somente vendem diretamente em Belém quando possuem mais de dez pacotes de farinha. Somente assim teriam alguma vantagem, pois acima desta quantidade de pacotes não precisam pagar a passagem de barco, que custa, por pessoa, quatorze reais. Levando acima de dez pacotes os camponeses pagam somente pelos pacotes levados.

Em Jutaí-Mirim as famílias também não estão livres da figura do marreteiro. Os que transitam em Jutaí moram na comunidade vizinha Ipanema e escoam a farinha pelo porto da Memória, no rio Bujaru, para ser levada para Belém. No caso da comunidade Nova Esperança, também existe a possibilidade de venda da farinha para o marreteiro que a leva para a feira do município de Marituba, na região metropolitana de Belém. Os camponeses que querem vender pessoalmente sua farinha viajam e transportam seus pacotes de farinha em caminhões dos próprios marreteiros, que passam todas as quintas na comunidade, pagando somente o preço do frete de cada pacote de farinha. Junto com a farinha para a comercialização muitas vezes também são levados o cupuaçu, o tucumã, a banana, a pupunha, ou qualquer outra fruta que as famílias tenham e que possa ser comercializada, principalmente nos meses de Dezembro e Janeiro, meses em que há maior abundância de frutas.

Em relação às culturas permanentes, em todas as comunidades encontramos o cultivo da pimenta-do-reino e de diversas frutas. Mas é em Nova Esperança que algumas famílias 
reservam parte da posse para estes cultivos que são plantados de forma consorciada como pimenta e cacau (Foto 30), abacaxi e côco, pimenta e pupunha, ou mais outras espécies. Muitos camponeses que plantam pimenta-do-reino, quando o plantio já está mais velho, aproveitam a área do pimental para plantar frutas.

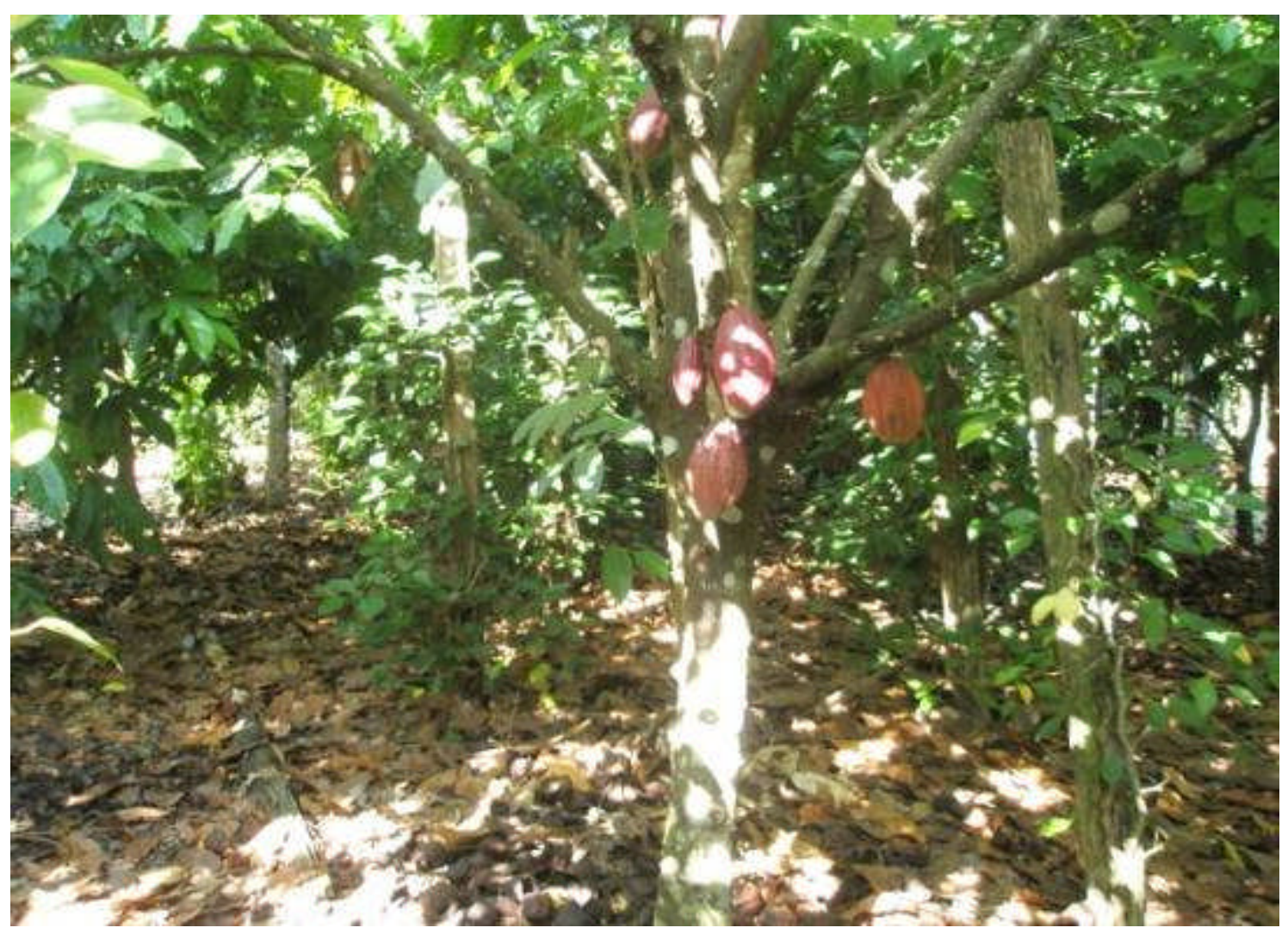

Foto 30: Área plantada com pimenta consorciada com o cacau, na comunidade Nova Esperança (foto da autora em out./2008).

Existe um grupo em Nova Esperança, formado por três famílias, que tiram a polpa de frutas como graviola, cupuaçu, abacaxi, açaí, maracujá, muruci, cacau e acerola e vendem para a Companhia Nacional de Abastecimento (CONAB). Existem duas famílias que aproveitam também as sementes do cacau e do cupuaçu que, depois de secadas, são vendidas na cidade de Concórdia do Pará. A produção deste pequeno grupo é individual, mas a venda é em conjunto.

Entre todas as frutas, a que predomina nestas comunidades é o açaí (Foto 31). A época desta fruta (setembro a dezembro) é considerada pelos camponeses como a época da fartura, principalmente para quem tem um açaizal na posse. É fartura para a família porque tem sempre a fruta à disposição para seu próprio consumo. Na hora da refeição, o açaí é acompanhado da farinha de mandioca e de alguma outra carne, peixe ou camarão. É fartura também porque é uma fruta muito procurada e, por isso, as famílias que possuem muitos pés 
de açaí aproveitam para vendê-la, mas somente quando aparece alguém para comprar e, no caso da família possuir quantidade que não comprometa o consumo familiar, principalmente na entressafra.

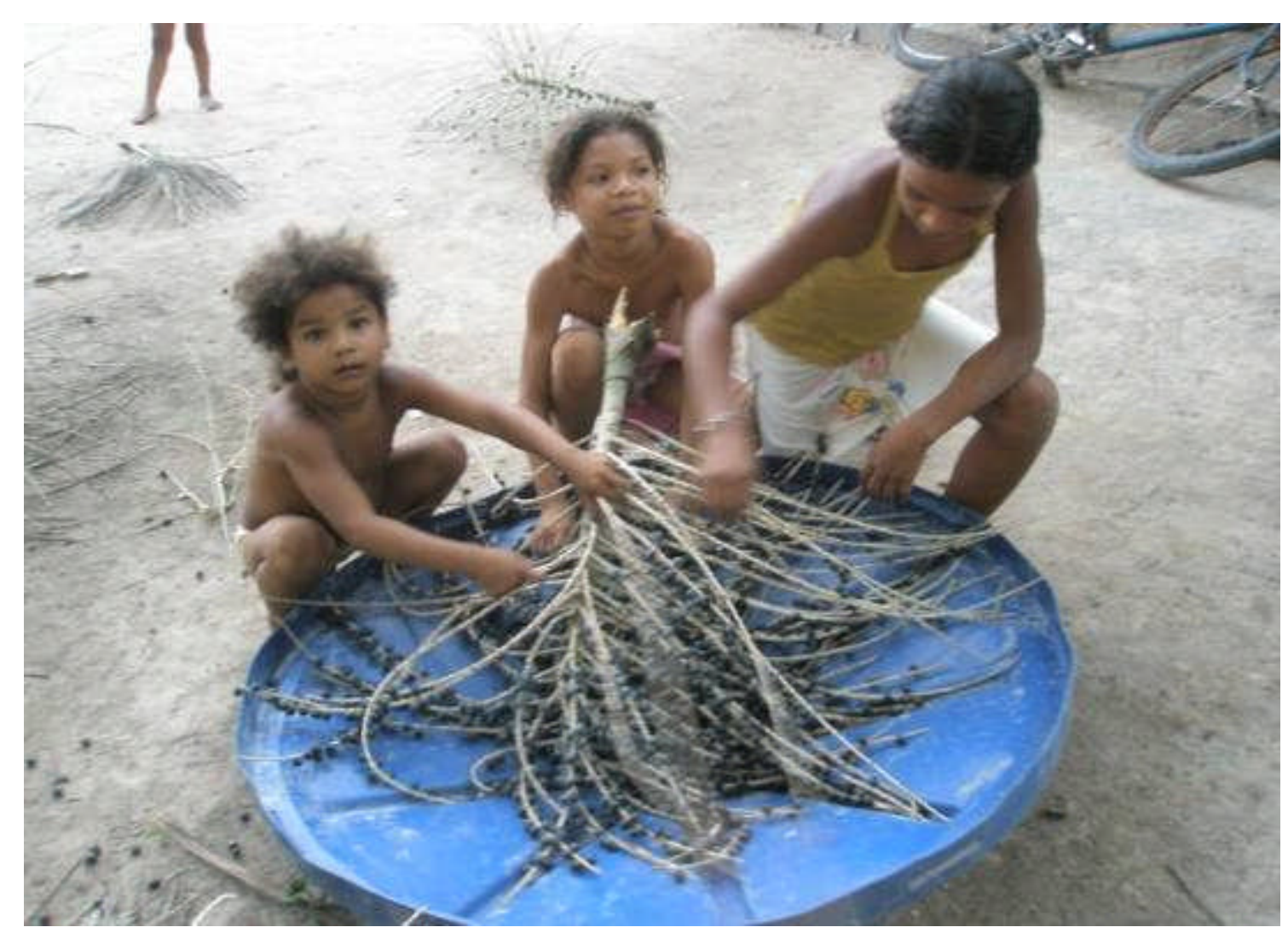

Foto 31: Em Nova Esperança, enquanto os pais raspam a mandioca, as crianças vão debulhando o açaí para o jantar (foto da autora em out./2008).

A pimenta-do-reino é um produto que existe em todas as comunidades, mas em Nova Esperança ela é o principal produto de algumas famílias, quando não é o único. O trabalho no pimental normalmente é da família, mas no momento do preparo das mudas e da colheita (“apanha") (de julho a setembro) é preciso contratar mão-de-obra. Os trabalhadores contratados normalmente são da própria comunidade, das comunidades vizinhas e até de outros municípios. Em 2008, estes trabalhadores recebiam cerca de R $\$ 0,25$ por quilo de pimenta colhida, sendo que geralmente cada trabalhador colhe em media cem quilos por dia, o que pode totalizar uma renda diária de 100,00. O pagamento do trabalho é feito semanalmente ou quinzenalmente, depois que a pimenta é vendida na cidade de Concórdia do Pará.

O início dos trabalhos se dá geralmente às $07 h 00$ e termina às 17:00, mas há aqueles que às vezes chegam às $06 h 00$. A alimentação é responsabilidade do próprio trabalhador, que 
às vezes leva os filhos para ajudarem na colheita. Estes trabalhadores usam um cavalete ${ }^{94} \mathrm{e}$ um saco com arame (bizaco) na frente ou ao lado do corpo para colocar a pimenta. Estes instrumentos de trabalho são cedidos pelo dono do pimental. No fim da tarde, a pimenta é pesada, o dono do pimental anota o quanto cada trabalhador colheu, armazena em sacos de sessenta quilos e guarda em galpões. O dono do pimental, ou seus filhos, acompanham essa colheita, pois o trabalhador, ao retirar os cachos da pimenteira, não pode debulhar a pimenta, pois podem ocorrer perdas.

O contrato de trabalho é feito diretamente com o dono e é por produção. De acordo com uma das trabalhadoras, o dono do pimental no qual ela trabalha dá um "agrado" em dinheiro para aqueles trabalhadores que ficam com ele até o fim da safra. Isto é uma forma de manter o trabalhador, pois este pode ir trabalhar com outro dono de pimental que pague mais pelo quilo colhido.

Além da fruticultura e do cultivo da pimenta-do-reino, as famílias também realizam outras atividades como:

- A criação de pequenos animais: geralmente galinhas do tipo caipira, mas também é possível encontrar galinhas de angola, patos, perus e porcos. São para o consumo da família, mas só mortos em ocasiões de necessidade, como na falta de outro alimento, ou uma comemoração (Foto 32).

\footnotetext{
${ }^{94}$ Armação móvel, com pé, dotada de suporte, na qual se apóiam os trabalhadores.
} 


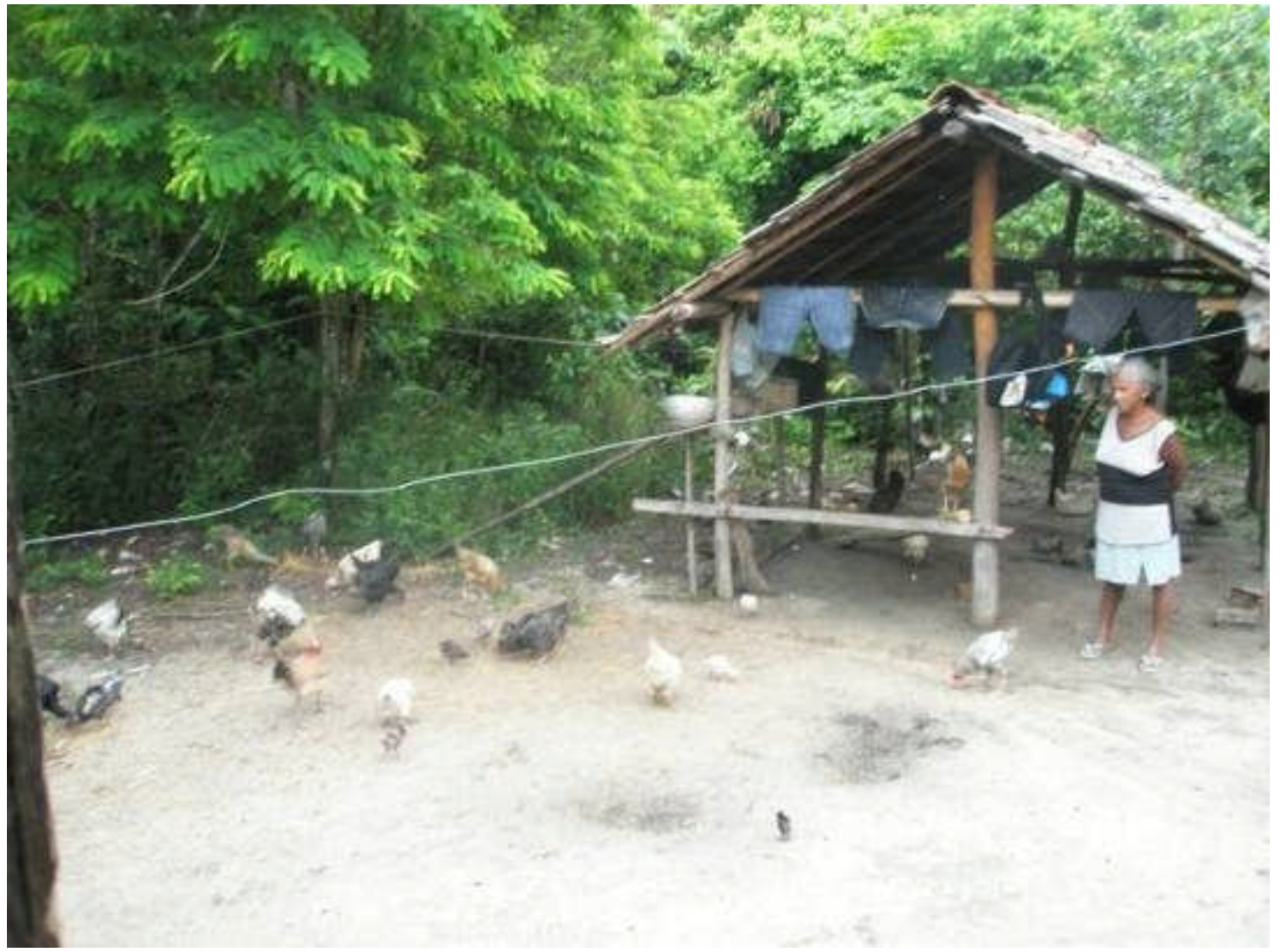

Foto 32: A senhora Maria, do Jutaí-Mirim, observa as galinhas enquanto elas comem. Ela está em baixo de uma barraca onde fica o local em que as galinhas põem os ovos, onde guardam a roupa do trabalho e onde ela faz o fogo para cozinhar ou assar alguma comida (foto da autora em jan./2009).

- Apicultura: desenvolvido por três famílias que participam da associação de Nova Esperança. Elas fizeram o curso em dezembro de 2008 e vendem o mel na comunidade, na cidade de Concórdia do Pará e fornecem para a CONAB.

- Piscicultura: em Nova Esperança e em Campo Verde existem algumas poucas famílias que criam peixes. Tilápia, Tambaqui e Pirapitinga são os peixes mais comuns e são criados somente para o consumo familiar. Em Nova Esperança esta atividade foi motivada pela associação que trouxe o curso para as famílias.

- Pesca: esta é uma atividade desenvolvida somente pelos que moram nas proximidades do rio Bujaru. Geralmente os moradores pescam, para o consumo familiar, com o que eles denominam de visor e flecha ou com a tarrafa e geralmente à noite (Foto 33). São freqüentes os casos em que um morador permite que algumas pessoas da cidade de Concórdia do Pará pesquem perto de sua casa, o que deixa outros moradores inconformados porque consideram 
que os peixes do rio e dos igarapés devem ser para o consumo da comunidade, principalmente devido à diminuição da quantidade de peixes que antes eles costumavam pescar.

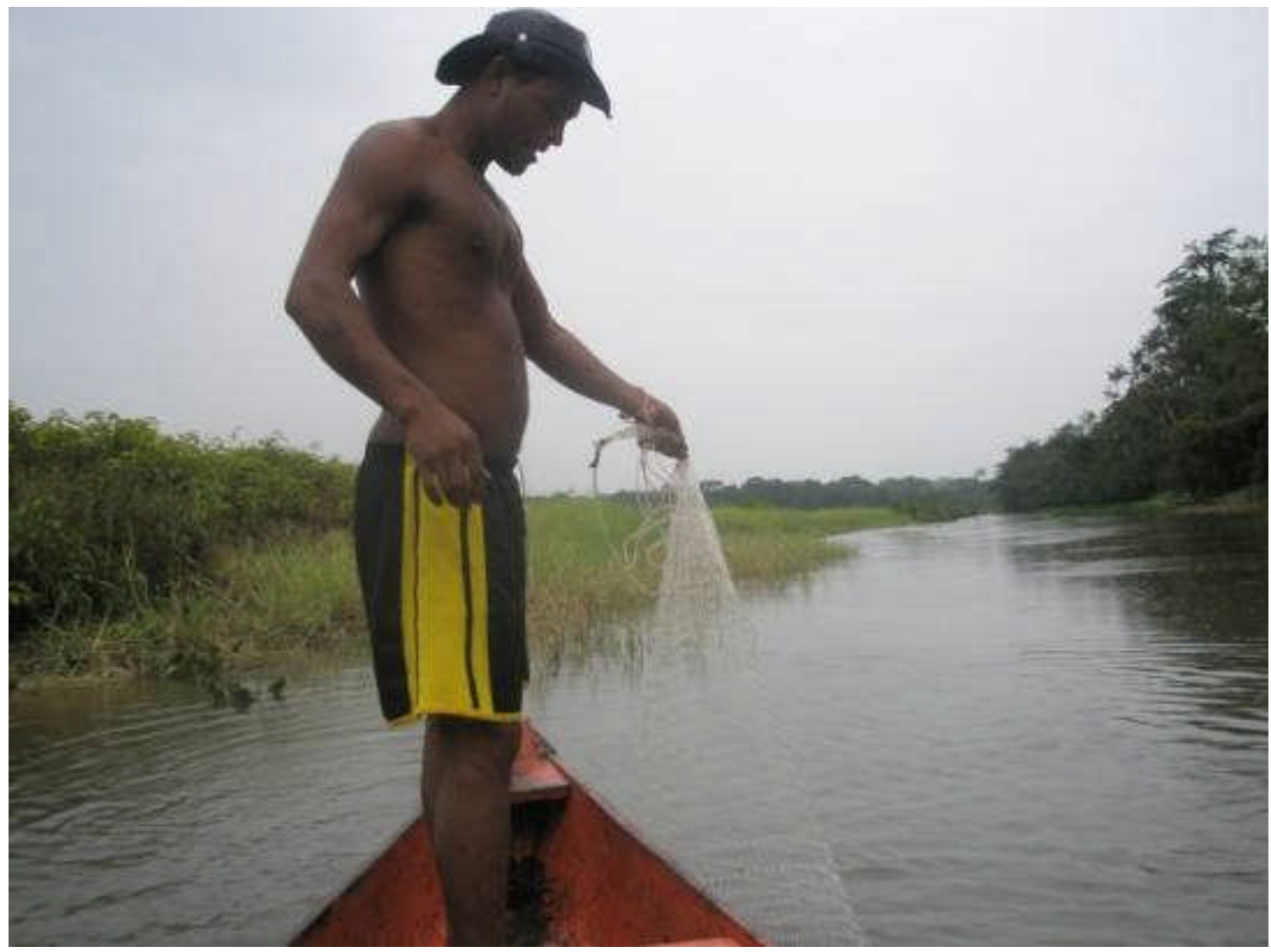

Foto 33: No rio Bujaru, o jovem José Maria espera o momento certo para puxar a tarrafa. Ele geralmente vai com a irmã, que neste momento rema a canoa e quando a tarrafa fica presa no fundo do rio, ela pula para soltar (foto da autora em dez./2008).

- Pecuária: Em Jutaí-Mirim existem três famílias que possuem pasto, mas somente duas têm o gado. Em Nova Esperança há três famílias que também criam gado em pequenos pastos. Mas estas famílias não vivem somente disto. Algumas têm roça, outra trabalha com apicultura, piscicultura, fruticultura, havendo uma combinação de atividades.

- Exploração da madeira: em todas as comunidades foi identificado certo grau de desenvolvimento desta atividade. Em Nova Esperança já existem poucas árvores que possam oferecer madeira para a comercialização. Nas outras comunidades, ainda é possível a extração da madeira, que é realizada principalmente para a construção de casas.

- Caça: das três comunidades estudadas, Campo Verde e Jutaí-Mirim são onde encontramos esta prática com mais freqüência, sendo realizada sempre à noite. Os animais mais 
encontrados são tatu e paca. Além destes animais, também é possível encontrar catitu e veado. Esta atividade somente é realizada para o consumo familiar, mas não é tão intensa como antes, pois já existem poucos animais nas matas da comunidade, principalmente em Nova Esperança.

- Silvicultura: Em Nova Esperança várias mudas de andiroba, acapu e cedro foram distribuídas pela prefeitura para vários camponeses, que vêem nesta atividade a oportunidade dos filhos e netos terem outra fonte de renda no futuro.

- Coleta da castanha-do-pará: É uma atividade que foi observada somente em Jutaí-Mirim, sendo realizada principalmente nas proximidades do rio Bujaru. A castanha é vendida para um dos moradores que depois revende para um barqueiro que leva a fruta para ser comercializada nos portos de Belém.

- Artesanato: também é desenvolvido por algumas mulheres da comunidade Nova Esperança. Por meio da associação, elas realizaram um curso e vendem sandálias ornamentadas e bolsas confeccionadas para uso próprio ou para comercialização a mulheres da própria comunidade e de outras. Esta atividade é desenvolvida individualmente por elas, da produção à comercialização (Fotos 34 e 35). 


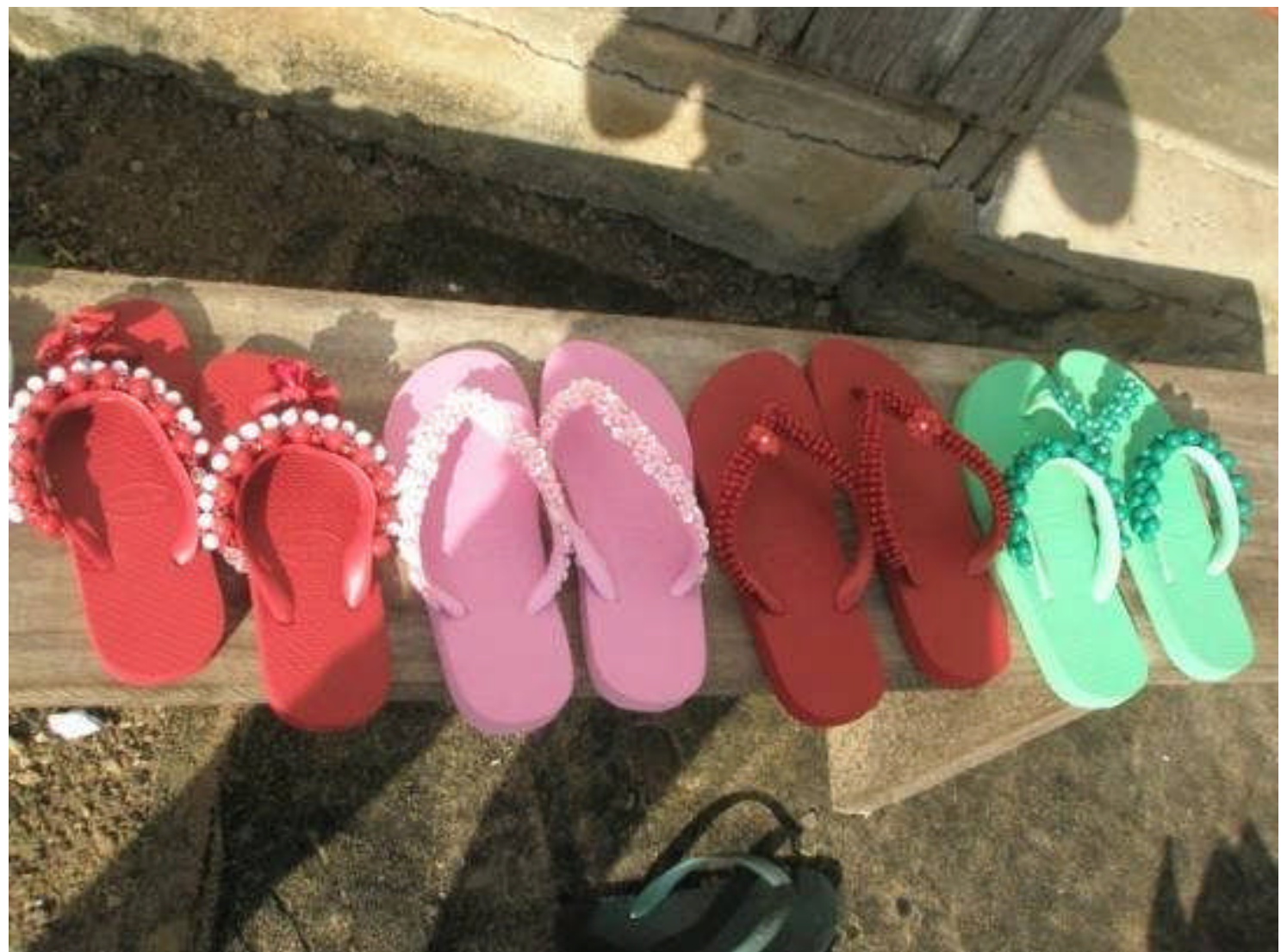

Foto 34: Sandálias ornamentadas pela senhora Graça, em Nova Esperança (foto da autora em out./2008).

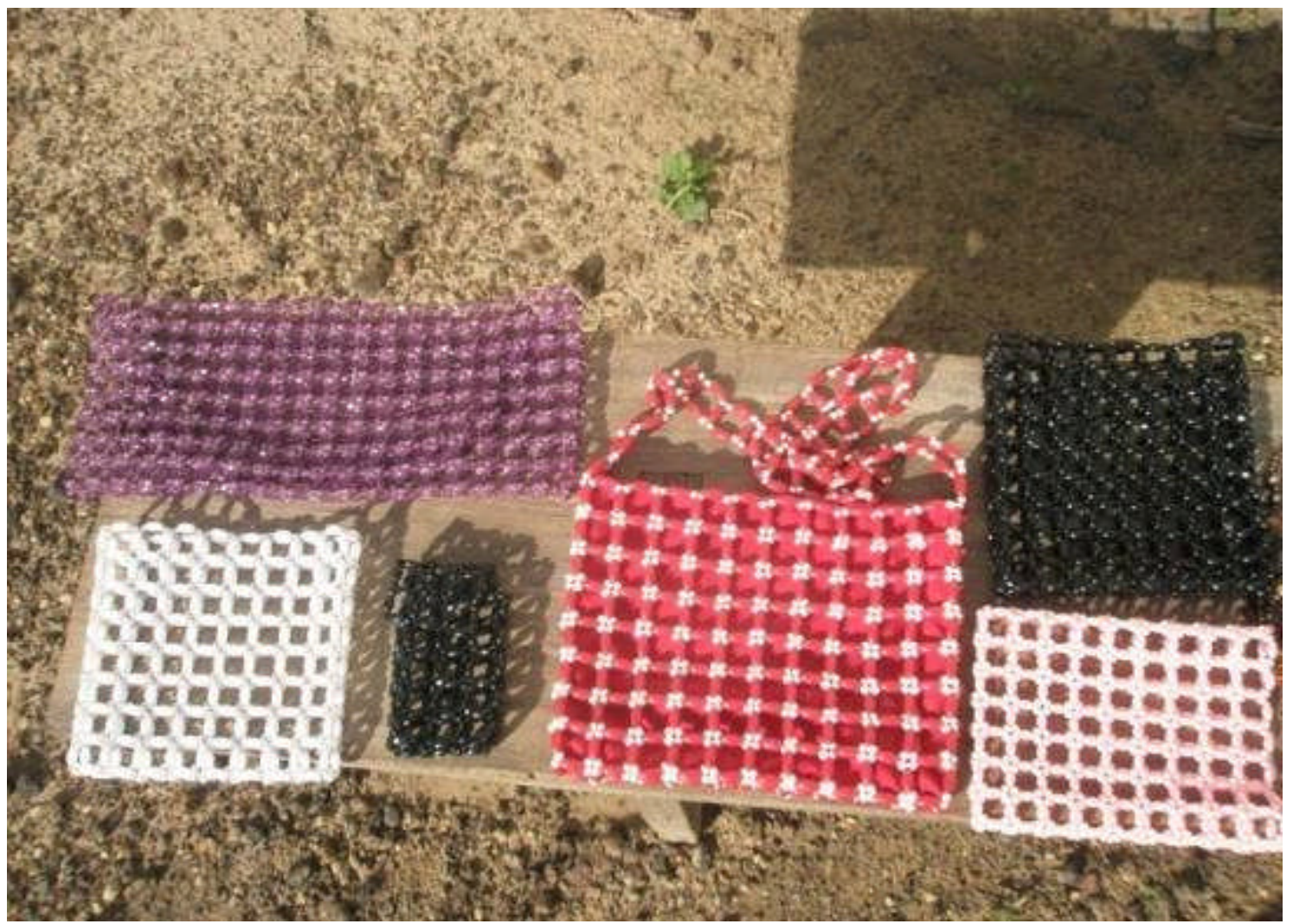

Foto 35: Bolsas confeccionadas pela senhora Graça, em Nova Esperança (foto da autora em out./2008). 


\section{CONSIDERAÇÕES FINAIS}

O objetivo deste estudo foi identificar e compreender as diversas formas de regularização fundiária que ocorrem no Pará, mais especificamente nas comunidades Campo Verde, Jutaí-Mirim e Nova Esperança, no município de Concórdia do Pará. Foi também verificar se estas formas imprimem diversas configurações territoriais no estado e como a diversidade de relações entre comunidade e outros grupos a elas externos interveio no processo de escolha dos camponeses sobre a melhor forma de regularizar suas terras.

Dois elementos foram utilizados pelas famílias tanto para aceitar o coletivo, como para negá-lo: A história de ocupação e o tempo. Em Campo Verde as famílias fazem questão de falar e mostrar seu passado enquanto negros descendentes dos escravos na região. Um número significativo de famílias em Nova Esperança, em oposição, justifica que são de fora, de outros municípios e estados, e que faz pouco tempo que estão no município e, portanto, não têm porque se envolver com o debate sobre a existência de comunidades quilombolas na região, menos ainda em autodefinir-se como tal. As família de Jutaí-Mirim são moradoras bem mais antigas nas terras, mas esse tempo e sua história de ocupação somente foram levados em consideração quando se iniciaram as reuniões para o reconhecimento como quilombolas. Com a chegada da proposta de criação de um assentamento, estes fatores foram deixados de lado, assim como a proposta da titulação coletiva e a autodefinição como quilombolas.

Mais do que vínculo com um passado de escravidão, outros fatores colaboraram para a decisão das famílias sobre de que forma legalizar suas posses. Campo Verde, Jutaí-Mirim e Nova Esperança são comunidades que possuem origens em momentos distintos, mas em muitos aspectos semelhantes, como a condição possessória da maioria das famílias, as formas organizativas relativas ao parentesco e à sociabilidade (que envolvem práticas econômicas, políticas, culturais, de lazer) e os vínculos extra-comunidade, como as relações com parentes nas cidades, com as instituições governamentais e movimentos sociais.

A unidade básica de trabalho destas famílias camponesas é a sua posse. Nela estão o sítio, o centro e o retiro. Todos são espaços de trabalho e socialização entre homens, mulheres, crianças, jovens e adultos, mas com suas devidas especificidades. As famílias buscam por meio do trabalho familiar, da ajuda mútua entre vizinhos, parentes e amigos, do trabalho acessório e do trabalho assalariado, as formas de sua recriação no dia-a-dia. Utilizando-se da terra, da água, da mata e dos saberes que possuem destes três elementos, as famílias se territorializam, criam seu território imprimindo uma especificidade ao mesmo. Não se trata de um território qualquer. Trata-se de um território camponês, marcado não 
somente pela família e seu trabalho, mas também pela comunidade, estrutura fundamental da sociabilidade, caracterizada pelo agrupamento das famílias vinculadas por um sentimento de localidade, pela convivência, por imbricadas relações de parentesco, vizinhança, pelas atividades políticas, econômicas e culturais. É ela que expressa a unidade territorial e política entre as famílias. É na comunidade que se vive e se convive com formas organizativas e, porque não, solidárias, que se expressam no lazer, na religião, na cultura, na política e na produção.

Todavia, o território camponês é passível de conflitos e contradições, tanto externamente quanto internamente. São conflitos que advêm do contexto que estas comunidades passam a vivenciar, principalmente a partir da década de 1970: a abertura da PA-140, o avanço da pecuária sobre as terras camponesas e a migração campo-cidade. Frente a estes acontecimentos, foi de grande importância a organização dos camponeses em torno do STR e da CPT com o objetivo de garantir a permanência na terra de um grande número de famílias posseiras.

A década de 1990 marca o início da divisão de opinião entre CPT e STR sobre que processo de regularização fundiária reivindicar e o que lhe está diretamente relacionado, que tipo de propriedade defender, a coletiva/quilombola ou a individual. Foi neste período que surgiram, por meio da mobilização do movimento negro e de estudos realizados pela universidade, as possibilidades de diversas comunidades buscarem seu reconhecimento como remanescentes de quilombos, de acordo com o artigo 68, da Constituição Federal de 1988.

A proposta do reconhecimento se difundiu, porém o estudo nas três comunidades demonstra que ela não foi um consenso em todas. Essa falta de consenso ocorria em torno do fato de que a titulação proveniente do reconhecimento é coletiva, portanto a terra não pode ser vendida. Esta situação provocou a desistência do reconhecimento de várias famílias de JutaíMirim e a adesão, pela expectativa dos recursos que viriam, ao Projeto de Assentamento. Em Nova Esperança a adesão das famílias à proposta coletiva foi mínima, o que facilitou a implementação do Programa Terra Legal Amazônia.

A diversidade de formas de regularização fundiária evidenciou a diversidade de sujeitos envolvidos com a titulação das terras, a disputa entre entidades (STR e ARQUINEC) pela adesão das comunidades às propostas que defendem, e permitiu o surgimento de novas lideranças e a conseqüente mudança nas relações de poder. .

O reconhecimento sob condição de o título ser coletivo e a terra não poder ser vendida foi o que colocou em lados opostos quem defendia o coletivo (MPA, ARQUINEC, CPT e alguns funcionários do INCRA/Belém) e quem defendia o individual (STR de Concórdia do 
Pará e representantes do INCRA/Tomé-Açu). Com o debate polarizado, principalmente, entre ARQUINEC e STR, uma série de incompreensões sobre o Território Quilombola foi aparecendo. Dentre as tantas idéias que foram sendo divulgadas, duas merecem ser destacadas. De um lado, a idéia de que quem tivesse sua terra titulada como coletiva não poderia usar o título para se aposentar. De outro, a idéia de que, se o título fosse coletivo, era o presidente da associação quem mandaria nas terras. Essas idéias, entre outras, provocaram uma resistência à associação e à gestão coletiva da terra.

Uma série de incompreensões deixavam de lado o verdadeiro sentido que estava sendo dado ao território quilombola pelas lideranças que o defendiam: o território significava uma forma de reparação por tudo o que o negro escravizado viveu, além de significar segurança para os seus descendentes, pois protegeria as terras das famílias do avanço da pecuária e da monocultura do dendê. Nesta perspectiva, o território quilombola se configura como uma estratégia política para garantir a permanência do campesinato negro na terra.

No que se refere aos desentendimentos acerca da titulação coletiva no interior das comunidades Jutaí-Mirim e Nova Esperança, pode-se dizer que nacionalmente os debates não eram diferentes. A busca, por parte de uma elite econômica vinculada à terra, por dificultar o andamento dos processos para a titulação das terras no Brasil inteiro, por meio do excesso de burocracia, impediu cada vez mais a formulação de novos processos.

A demora nos procedimentos para a titulação colaborou para que inúmeras famílias em Jutaí-Mirim desistissem do reconhecimento e serviu como argumento para os contrários à titulação coletiva. Outro elemento que colaborou para essa desistência, de forma decisiva, foi a crescente mobilização em prol do PA. Os que lideravam a defesa do PA prometiam melhorias na habitação, saneamento, construção de estradas e acesso à energia elétrica de forma mais rápida para as famílias, além da garantia da titulação individual. $\mathrm{O}$ assentamento também era visto como uma outra forma de garantir a permanência na terra, principalmente pelos recursos que podem ser obtidos a partir da sua criação.

A criação de assentamentos pode trazer um dinamismo para a economia local e isto não parece ser desconsiderado pela administração municipal. De acordo com Medeiros (2003), a criação de assentamentos tende a gerar um incremento populacional na região onde se instala e tem efeitos sobre a paisagem e a economia local (comércio de insumos e implementos agrícolas, material de construção, eletrodomésticos, etc.). Em alguns casos, implica na ampliação do mercado de trabalho e de consumo, incrementa a arrecadação de impostos, etc. Mas isto ocorre, principalmente, quando envolve o deslocamento populacional, o que não quer dizer que não possa ocorrer um certo dinamismo quando é a regularização. 
O caso de Jutaí-Mirim é criação de um assentamento em área de antiga ocupação, portanto a ação é de regularização fundiária. Mesmo assim, ele gera um certo dinamismo no mercado local, pois as compras para o assentamento são realizadas no município, nas lojas e mercados da cidade.

No caso de Nova Esperança, a aceitação da titulação coletiva foi por parte de uma minoria. Com a chegada dos técnicos do Programa Terra Legal, no fim de 2009, algumas famílias que desejavam a titulação coletiva, junto com as demais famílias da comunidade que não aceitavam, cadastraram-se no programa. Apesar de Nova Esperança estar cadastrada na FCP, suas famílias já estão tendo suas terras legalizadas pelo Terra Legal. Isto porque a maioria das famílias não legitima o cadastro, por acreditar que o mesmo foi feito sem um acordo entre todas, por isso se sentem livres para regularizar as terras como acham melhor.

Como pode ser observado, o Estado se apresenta para estas comunidades por meio de uma diversidade de formas de regularização. Mas isto não garante a confiança e o crédito por parte das famílias em relação a sua ação. Isto porque no início da década de 1980 a titulação foi prometida às famílias, porém foram pouquíssimas as que receberam o título. Mesmo que o Estado apareça com o apoio de entidades, que de certa maneira afiançam sua ação, a desconfiança e o descrédito permanecem por parte de algumas famílias.

Podemos observar que com a experiência advinda de inúmeras reuniões, mobilizações em torno do reconhecimento ou não das comunidades como remanescentes dos quilombos, houve o surgimento de novas lideranças que impulsionaram novas iniciativas políticas que, por sua vez, alteraram as relações de poder dentro das comunidades e também no município. Tanto assentados quanto quilombolas passaram a contar no jogo político local. O próprio Estado também se apresenta com novos agentes, como os técnicos do MDA, que vêm oferecendo outra forma de os camponeses poderem legalizar suas posses.

Com o surgimento de novas lideranças e de novas formas organizativas, como a ARQUINEC e a associação de assentados de Jutaí-Mirim, há uma cobrança maior por parte desses camponeses sobre a atuação do Estado a respeito das prioridades que devem ser atendidas. Os assentados reivindicam a continuação dos trabalhos no assentamento; os quilombolas reivindicam o respeito ao seu território. Quanto às famílias cadastradas no Terra Legal, o que há é a crítica em relação à demora na entrega da titulação definitiva.

A emergência de novas lideranças se expressou nas eleições de 2008, em que tanto uma das lideranças quilombolas, como uma das lideranças que defendia o PA em Jutaí-Mirim se candidataram a uma vaga na Câmara Municipal de Concórdia, saindo vencedora somente a liderança quilombola. 
A ARQUINEC e a associação criada em Jutaí-Mirim expressam a participação destas novas lideranças. Atuar nestes espaços não é somente poder falar para as próprias comunidades, mas ser ouvidos por elas. É também poder falar por elas e ser ouvidos pelo poder público. As lideranças são formadoras de opinião, e de uma forma ou de outra, tiveram e têm importância fundamental na constituição dos interesses de quem representam e no seu reconhecimento social. Com a ação da ARQUINEC, por exemplo, o debate em torno dos territórios quilombolas passou a fazer parte do debate político local.

Em meio ao surgimento de novas lideranças, o STR busca se reafirmar também como representante dos interesses dos camponeses. O sindicato atua, de um lado, no sentido de consolidar sua presença dentro das comunidades por meio da criação de assentamentos em algumas delas e dentro deles a Delegacia Sindical, como foi o caso do assentamento JutaíMirim; de outro, no sentido de apoiar intensivamente as Delegacias já existentes, como é o caso de Nova Esperança. No caso de Campo Verde, o delegado sindical, que não concordava com o posicionamento do STR de Concórdia do Pará, apoiou a ARQUINEC. Um dos motivos de seu apoio foi o receio de que com a criação de um assentamento, suas terras (cerca de 100 ha) fossem divididas e distribuídas a outras famílias. A aceitação da titulação coletiva foi a alternativa encontrada para assegurar as terras nas mãos da família para que os filhos pudessem ter um meio de sobrevivência, mesmo os que moravam na capital, pois se um dia a vida na cidade não der certo, a terra estará lá na comunidade à espera deles. O outro motivo exposto foi que, com a titulação coletiva, as terras estariam menos vulneráveis às investidas de terceiros, como os fazendeiros seus vizinhos. .

O debate em torno da regularização envolveu a criação de novos laços, novas lideranças e o fortalecimento das já existentes. São lideranças representantes de entidades, associações e movimentos sociais que buscam definir ou nortear os caminhos que devem ser percorridos pelas famílias para conseguirem regularizar suas posses. São lideranças que disputam por espaço político dentro e fora das comunidades e pela territorialização, no território camponês, das entidades, associações e movimentos sociais que representam.

Cada família, ao aceitar a titulação coletiva ou a individual, tem expectativas e projetos que envolvem esta escolha. A expectativa é ter, enfim, seu direito à propriedade da terra reconhecido, pois isso o título é esperado com ansiedade. Outra expectativa é que o passo dado traga, nos casos de Jutaí-Mirim e Campo Verde, melhorias para a comunidade, e como melhorias esperam a construção de uma boa estrada vicinal, o acesso à energia elétrica a todos os integrantes da comunidade, a ampliação da oferta de transporte, a construção de 
escola e posto de saúde nas comunidades. No caso de Nova Esperança, por ser uma comunidade com melhor infra-estrutura, a preocupação é mesmo com o título individual.

Para todas, o projeto é que no futuro os filhos possam ter segurança jurídica em relação às suas terras, tenham como viver da terra, sem correr o risco de perdê-las por algum motivo. Esta segurança também vale para os filhos que moram na cidade pois, se a vida na cidade não der certo, eles têm a terra para viver e trabalhar. Desta forma, vemos que a terra é o meio de produção fundamental para estes camponeses. 


\section{REFERÊNCIAS}

ACEVEDO MARIN, Rosa; CASTRO, Edna Ramos. Negros do Trombetas : Guardiães de matas e rios. $2^{\text {a }}$ ed. Revista e Ampliada. Belém: CEJUP/NAEA/UFPA, 1998.

Mobilização política de comunidades negras rurais domínios de um conhecimento praxiológico. Novos Cadernos do NAEA, Belém, vol. 2, nº 2, p. 74-106, dezembro, 1999. Disponível em: <http://www.periodicos.ufpa.br/index.php/ncn/issue/ view/14>. Acesso em: 12 out. 2007.

Quilombolas do Pará. Belém: NAEA/UFPA, 2005. 1CD-ROM.

ALMEIDA, Alfredo Wagner Berno de. Os quilombolas e as novas etnias. In: O'DWYER, Eliane Cantarino (Org.). Quilombos: identidade étnica e territorialidade. Rio de Janeiro: Editora FGV, 2002.

Os quilombolas e base de lançamento de foguetes de Alcântara: laudo antropológico / Alfredo Wagner Berno de Almeida. - Brasília: MMA, 2006.

ANDRADE, Lúcia M. M. de. Terra de Quilombo: herança e direito. $4^{\mathrm{a}}$ Ed. Atualizada. São Paulo: CPI-SP, 2007.

O Direito à Consulta Livre, Prévia e Informada: os limites da "consulta" aos quilombolas. 2008. Disponível em: <http://www.cpisp.org.br>. Acesso em: 19/11/2009.

ARRUTI, José Maurício. O quilombo entre dois governos. Tempo e Presença, Rio de Janeiro, $\mathrm{n}^{\mathrm{o}}$ 330, p.10-15, julho/agosto, 2003. Disponível em: <http:// www.koinonia.org.br/oq/uploads/biblioteca/Zemaur.pdf >. Acesso em: 25 jun. 2009.

- Recuperação da memória do lugar auxilia laudo antropológico. ComCiência. Entrevista concedida em 10/03/2004. Disponível em: <http://www.comciencia.br/entrevistas/memoria/arruti.htm>. Acesso em: 20 jun. 2009.

Mocambo: Antropologia e história do processo de formação quilombola. São Paulo:

EDUSC, 2006.

ARQUINEC. Associação dos Remanescentes de Quilombo de Concórdia do Pará; ARQUIOB. Associação Remanescente de Quilombo Oxalá de Bujaru. Quilombolas de Bujaru e de Concórdia - Pará. Belém: [s.n], 2006. (Projeto Nova Cartografia Social da Amazônia, Série Movimentos sociais, identidade coletiva e conflitos, 11).

ARQUINEC. Associação dos Remanescentes de Quilombo de Concórdia do Pará. Ata da assembléia extraordinária da ARQUINEC. Santo Antônio, Concórdia do Pará, 27/08/2005. Nota de Esclarecimento. Concórdia do Pará, 18/03/2006.

ATA da reunião com os membros dos quilombolas e assentados do Jutaí. Concórdia do Pará: 17/12/2007. 
BARBOSA, Anna Izabel Costa; GRANDO, Raquel Lopes Sinigaglia Caribé. A Dança dos Quilombos. In: Encontro da ANPPAS, 3, 2006, Brasília-DF. Disponível em: <http://www.anppas.org.br/encontro_anual/encontro3/GT6.html>. Acesso em: 11 jun. 2009.

BARROS, Edir Pina de. Quilombos e Quilombolas: A contribuição da Associação Brasileira de Antropologia, 2007. Disponível em:< http://recantodasletras.uol.com.br/trabalhosaCademicos/1297024>. Acesso em: 19 nov. 2009.

BERGAMASCO, Sônia Maria; NORDER, Luis A. Cabello. O que são assentamentos rurais. São Paulo: Editora Brasiliense, 1996. (Coleção Primeiros Passos, no 301).

BETTO, Frei. O que é comunidade eclesial de base. $6^{\circ}$ ed. São Paulo: Editora Brasiliense, 1986. (Coleção Primeiros Passos, $n^{\circ} 19$ ).

Comunidades Eclesiais de Base. Fermento de marca boa. Entrevista com Frei Betto. In: Sem Fronteiras. A Igreja no Brasil aberta ao mundo, $\mathrm{N}^{\circ}$ 252, Julho 1997, pág.5. Disponível em: <http://ospiti.peacelink.it/zumbi/news/semfro/252/sf252p05. html>

BRANDÃO, Carlos Rodrigues. O que é método Paulo Freire. São Paulo: Editora Brasiliense, 2005. (Coleção Primeiros Passos, 38).

BRASIL. Constituição Federal, 1988.

- Decreto $\mathbf{n}^{\circ} \mathbf{4 . 8 8 7}$, de 20 de novembro de 2003. Disponível em: http://www.cpisp.org.br/ htm/leis/legislacaofederal.aspx>. Acesso em: 02 fev. 2009.

- Portaria da FCP $\mathbf{n}^{\mathbf{0}} \mathbf{6}$, de $1^{\circ}$ de março de 2004. Disponível em: http://www.cpisp.org.br/htm/leis/page.aspx?LeiID=141>. Acesso em 02 fev. 2009.

. Fundação Cultual Palmares. Portaria no 29, de 12 de dezembro de 2006. Diário Oficial da União, seção 1, n 238, quarta-feira, 13 de dezembro de 2006, p.60. Disponível em: <http://www.in.gov.br/visualiza/index.jsp?data=13/12/2006\&jornal=1\&pagina=60\& total Arquivos=232>. Acesso em: 21 abr. 2010.

(a). Ministério da Fazenda. Ministério da Justiça. Secretaria de Acompanhamento Econômico. Secretaria de Direito Econômico. Parecer Técnico no 06301/2009/RJ. Em 27 de maio de 2009.

(b). Lei $\mathbf{n}^{\mathbf{0}}$ 11.952, de 25 de junho de 2009. Disponível em: <http://www.planalto.gov.br/ccivil_03/_ato2007-2010/2009/lei/111952.htm>. Acesso em: 15 fev. 2010.

. Ministério de Desenvolvimento Agrário. Programa Terra Legal Amazônia.2010 Disponível em: <http://portal.mda.gov.br/arcoverde/pages/a\%c3\%a7\%c3\%b5esdoPrograma>. Acesso em: 14 fev. 2010.

CARTA de Esclarecimento ao INCRA. Concórdia do Pará, PA. 21/10/2005. 
CASTRO, Edna. Quilombolas de Bujaru: Memória da escravidão, territorialidade e titulação da terra. Belém: Secretaria de Justiça do Estado; UNAMAZ, 2003. 1 CD-ROM.

CHASIN, Ana Carolina da Matta; PERUTTI, Daniela Carolina. Os retrocessos trazidos pela Instrução Normativa do INCRA n. ${ }^{\circ}$ 49/2008 na garantia dos direitos das Comunidades Quilombolas, 2009. Disponível em: <http://www.cpisp.org.br>. Acesso em: 05 jul. 2009.

CNA. Confederação da Agricultura e Pecuária do Brasil. 2009. Disponível em: <http://www.cna.org.br/site/down_anexo.php?q=E22_1416928122006.doc>. Acesso em: 20 jun. 2009.

CNBB. Conselho Nacional dos Bispos do Brasil. 2009. Disponível em: <http://www.cnbbn2.org.br>. Acesso em: 09 jul. 2009.

Carta Final do $\mathbf{1 2}^{\mathbf{0}}$ Intereclesial às Comunidades. 2009. Disponível em: $<$ http://www.oarcanjo.net/site/index.php/noticias/carta-final-do-12-intereclesial-ascomunidades/>. Acesso em 20 mai. 2010.

COMBLIN, Pe. José. O Projeto de Aparecida. Notícias, 08/03/2008. Disponível em:<http://www.oraetlabora.com.br/artigos/projeto_de_aparecida.htm>. Acesso em: 20 mai. 2010 .

CONAQ. Coordenação Nacional de Comunidades Rurais Quilombolas. 2009. Disponível em: <http://www.conaq.org.br/>. Acesso em: 08 jul. 2009.

COSTA, Rita de Cássia Pereira. "Como uma Comunidade": formas associativas em Santo Antonio /PA - imbricações entre parentesco, gênero e identidade. 2008. Dissertação de Mestrado apresentada ao Programa de Pós-Graduação em Ciências Sociais - Antropologia, do Instituto de Filosofia e Ciências Humanas da Universidade Federal do Pará.

COSTA, Antonio Maurício Dias da. Bailes da "Saudade" e do "Passado": atualidades do circuito bregueiro de Belém do Pará. Pontourbe - Revista do Núcleo de Antropologia Urbana da USP. Ano 2, versão 3.0, julho de 2008. Disponível em: <http://n-au.org/pontourbe03/mauriciocosta.html>. Acesso em: 12 mai. 2010.

CPI-SP. Comissão Pró-Índio de São Paulo. Direitos Ameaçados. 2009. Disponível em: $<$ http://www.cpisp.org.br/htm/leis/legislacao_federal.aspx?LinkID=53>. Acesso em: 10 nov. 2009.

Terras Quilombolas: Balanço 2009. 2010. Disponível em: <www.cpisp.org.br/upload/editor/file/TerrasQuilombolasBalanco2009.pdf>. Acesso em: 10 mai. 2010. 
CPT. Comissão Pastoral da Terra. Ofício ao ITERPA. Bujaru, 17/08/2000.

(a). Ofício ao ITERPA. Bujaru, 16/07/2001.

(b). Ata da reunião sobre terras remanescentes de quilombos. Vila de

Santana/Bujaru, 18/08/2001.

Um pouco da história de escravidão do povo afro no Brasil, no Pará e na região guajarina. Ananindeua: CPT, 2003. (Série Cadernos Kizomba, 1).

. Padre Sérgio Tonetto: uma vida dedicada aos pobres de Deus. Comissão Pastoral da

Terra, Goiânia, ano 33, $\mathrm{n}^{\mathrm{o}}$ 191, p. 3, jan-mar, 2008. Disponível em: <http://www.cptnac.com.br>. Acesso em: 02 jul. 2009.

DOMEZI, Maria Cecília. A devoção nas CEBs: entre o Catolicismo Tradicional popular e a teologia da libertação. Doutorado em Ciências da Religião. Pontifícia Universidade Católica de São Paulo, São Paulo, 2006. Disponível em: <www.sapientia.pucsp.br/tde_busca/arquivo.php?codArquivo=2822>. Acesso em: 18 mai. 2010 .

FERREIRA, João Carlos Vicente (Org). O Pará e seus municípios. Belém: SECULT, 2003.

FREITAS, Sônia Maria de. História Oral: possibilidades e procedimentos. $2^{\mathrm{a}}$ ed. São Paulo: Associação Editorial Humanitas, 2006.

GOMES, Flávio. Quilombos e Mocambos: camponeses negros e a experiência do protesto coletivo no Brasil escravis ta. In: MEC. Educação African idades Brasil. Brasília: UNB, 2006.

INCRA. Instituto Nacional De Colonização E Reforma Agrária. Comunidades quilombolas Santo Antônio, Ipanema, Igarapé Dona e Campo Verde. Belém: INCRA, 2005. (Relatório Técnico de Vistoria, $\mathrm{n}^{\circ} 187$ ).

(a). Diagnóstico ambiental da área de influência do projeto de assentamento JutaíMirim: os empreendimentos previstos para 2008. Belém: INCRA, 2008.

(b). Região do Rio Bujaru, Concórdia do Pará. Belém: INCRA, 2008. (Relatório de Viabilidade Ambiental).

Coordenação Geral de Regularização de Territórios Quilombola, maio de 2009. Disponível em: <http://www.incra.gov.br>. Acesso em: 07 jul. 2009.

. Títulos expedidos às comunidades quilombolas, 26 de agosto de 2010. Disponível em: <http://www.incra.gov.br/portal/arquivos/institucional/quilombolas/titu los_expedidos.pdf.>. Acesso em: 05 out. 2010.

IBGE. Instituto Brasileiro de Geografia e Estatística. Concórdia do Pará. Disponível em: <http://www.ibge.gov.br/cidadesat/topwindow.htm?1>. Acesso em: 29 jan. 2009.

29 jan. 2009

Censo Agropecuário, 2006. Disponível em: 〈http://www.ibge.gov.br>. Acesso em: 
LEITE, Ilka Boaventura. Os quilombos no Brasil: questões conceituais e normativas. Etnográfica, vol. IV, $\mathrm{n}^{\circ}$ 2, p. 333-354, 2000. Disponível em: <http://www.cfh.ufsc.br /nuer/artigos/osquilombo s.htm>. Acesso em: 15 ago. 2006.

LOPES, Helena Theodoro; SIQUEIRA, José Jorge; NASCIMENTO, Maria Beatriz. Introdução ao conceito de quilombo. In: - Negro e Cultura no Brasil: pequena enciclopédia da cultura brasileira. Rio de janeiro: UNIBRADE/UNESCO, 1987. p. 25-39.

MALCHER, Maria Albenize Farias. Identidade Quilombola e Território. In: Encuentro de Geógrafos de América Latina, 12, 2009, Montevideo/Uruguay. Anais do 12 Encuentro de Geógrafos de América Latina. Montevideo/Uruguay: Easy Planners, 2009. 1 CD-ROM.

MALUnGU(a). Coordenação das Associações das Comunidades Remanescentes de Quilombos do Pará(a). Estatuto. Belém/PA: MALUNGU, 2008.

(b). Cartilha do II Encontro Estadual dos Quilombolas do Pará. Belém/PA: Fase Amazônia, 2008.

MARQUES, Jane Aparecida e MALCHER, Maria Ataide (org.). Regularização Territorial: a regularização fundiária como instrumento de ordenar o espaço e democratizar o acesso à terra. Belém: ITERPA, 2009. 74 p. Disponível em: $<w w w . i t e r p a . p a . g o v . b r / f i l e s / . . / / c a d e r n o \_r e g u l a r i z a c a o \_t e r r i t o r i a l . p d f>$. Acesso em: 14 mar. 2010.

MEDEIROS, Leonilde Servolo. Reforma agrária no Brasil: História e atualidade da luta pela terra. São Paulo: Fundação Perseu Abramo, 2003. (Coleção Brasil Urgente).

MEDEIROS, Maria Franco Trindade; SENNA-VALLE, Luci de; ANDREATA, Regina Helena Potsch. Histórico e o uso da "salsa parrilha" (Smilax spp.) pelos boticários no Mosteiro de São Bento. Revista Brasileira de Biociências, Porto Alegre, v. 5, supl. 1, p. 2729, jul. 2007. Disponível em: <http://www6.ufrgs.br/seerbio/ojs/index.php/rbb/article/ viewFile/57/60>. Acesso em: 29 out. 2010.

MELO, Paula Balduino de. Análise da Mobilização Política das Comunidades Remanescentes de Quilombos. In: VII RAM. 2007. Porto Alegre : UFRGS, 2007.

MOURA, Margarida Maria. Camponeses. São Paulo: Ática, 1986. (Série Princípios, 52).

NEAD. Núcleo de Estudos Agrários e Desenvolvimento Rural. Boletim NEAD. s/d. Disponível em: < http://www.nead.org.br/boletim/boletins/boletim4.htm>. Acesso em: 19 fev. 2010. 
OLIVEIRA, Ariovald o Umbelino de. A geografia agrária e as transformações territoriais recentes no campo brasilei ro. In: CARLOS, Ana Fani Alessandri (org.). Novos caminhos da geografia. São Paulo: Contexto, 2005. p. 63-110. (Coleção Caminhos da Geografia).

A "Não Reforma Agrária" do MDA/INCRA no governo Lula. Revista Reforma Agrária. vol. 33, nº 2. ago / dez. São Paulo: ABRA, 2006.

A regularização fundiária da MP 458 é a contra-reforma agrária do governo Lula. 2009. Disponível em: <http://www.radioagencianp.com.br>. Acesso em: em 12 fev. 2010.

OLIVEIRA, Rosiska Darcy de; OLIVEIRA, Miguel Darcy de. Pesquisa social e ação educativa: conhecer a realidade para poder transformá-la. In: BRANDÃO, Carlos Rodrigues. Pesquisa Participante. São Paulo: Brasiliense, 1981.

PARÁ(a). Constituição (1989). Constituição do Estado do Pará. Belém: Consultoria Geral do Estado, 2007. Disponível em: 〈http://www.pa.gov.br〉. Acesso em: 01 jul. 2009.

(b). Lei n ${ }^{\circ} 6.941$, de 17 de janeiro de 2007. Estabelece políticas públicas específicas à população negra do Estado do Pará, visando o combate às desigualdades sociais e à discriminação racial e dá outras providências. Comissão Pró-Índio de São Paulo. Disponível em: http://www.cpisp.org.br/htm/leis/legislacaoestadual.aspx>. Acesso em: 02 fev. 2009.

(c). Decreto $\mathrm{n}^{\mathrm{o}}$ 562, de 1 de novembro de 2007. Cria Grupo de Trabalho para Consciência Negra e Promoção da Igualdade Racial no âmbito do Estado do Pará. Comissão Pró-Índio de São Paulo. Disponível em: http://www.cpisp.org.br/htm/leis/

legislacaoestadual.aspx>. Acesso em: 02 fev. 2009.

(d). Secretaria de Estado de Planejamento, Orçamento e Finanças, SEPOF. Estatística

municipal. Concórdia do Pará, 2007. Disponível em: <http://www.sepof.pa.gov.br/municipio.html〉. Acesso em: 04 jan. 2009.

(a). Estatística municipal. São Domingos do Capim, 2008. Disponível em: <http://www.sepof.pa.gov.br/municipio.html>. Acesso em: 04 jan. 2009.

(b). Secretaria de Estado de Justiça e Direitos Humanos. SEJUDH. Plano Estadual de Políticas de Promoção da Igualdade Racial. Belém: SEJUDH, 2008. Disponível em: <http://www.sejudh.pa.gov.br>. Acesso em: 05 fev. 2009.

Imprensa Oficial do Estado do Pará. Diário Oficial do Estado do Pará. No 31.392. Sexta-Feira, 03 de abril de 2009. Caderno Executivo 5, pag. 15. Disponível em: http://www.ioepa.com.br/diarios/2009/04/03/03.04.executivo.05.pdf. Acesso em: 07 jun. 2010.

RAFFESTIN, Claude. Por uma geografia do poder. Tradução de Maria Cecília França. São Paulo: Ática, 1993. (Série Temas, 29).

SCHMITT, Alessandra; TURATTI, Maria Cecília Manzoli; CARVALHO, Maria Celina Pereira de. A atualização do conceito de quilombo: identidade e território nas definições teóricas. In: Ambiente e Sociedade. No 10. Jan./Jun. 2002. Núcleo de Estudos e Pesquisas Ambientais. Disponível em: <http://www.scielo.br/scielo.php>. Acesso em: 27 mar. 2008. 
SOUZA, Robson Sávio Reis. O comunitarismo cristão e suas influências na política brasileira: uma revisão bibliográfica sobre o comunitarismo católico no Brasil. 2008. Revista Horizonte, Belo Horizonte, v. 6, n. 12, p.41-68, jun. 2008.

TAVARES DOS SANTOS, José Vicente. Colonos do vinho: estudo sobre a subordinação do trabalho camponês ao capital. São Paulo: HUCITEC, 1978. (Coleção Ciências Sociais, Série Realidade Social).

TEIXEIRA, Faustino. Comunidades Eclesiais de Base no Brasil. 2005. Disponível em: http://www.iserassessoria.org.br/novo/arqsupload/89.DOC. Acesso em: 18 mar. 2010

TRECCANI,Girolamo Domenic o. Terras de Quilombo: caminhos e entraves do processo de titulação. Belém: secretaria Executiva de justiça. Programa Raízes, 2006.

TRINDADE, Joseline Simone Barreto. Nós, quilombola? A construção da identid ade quilombola a partir dos levantamentos de comunidades negras rurais no Estado do Pará. In: Revista OQ. Ano1, $\mathrm{n}^{\circ}$.1, janeiro-dezembro de 2005. Disponível em: <http://www.koinonia.org.br/oq/ensaio.htm>. Acesso em: 20 set. 2006. 